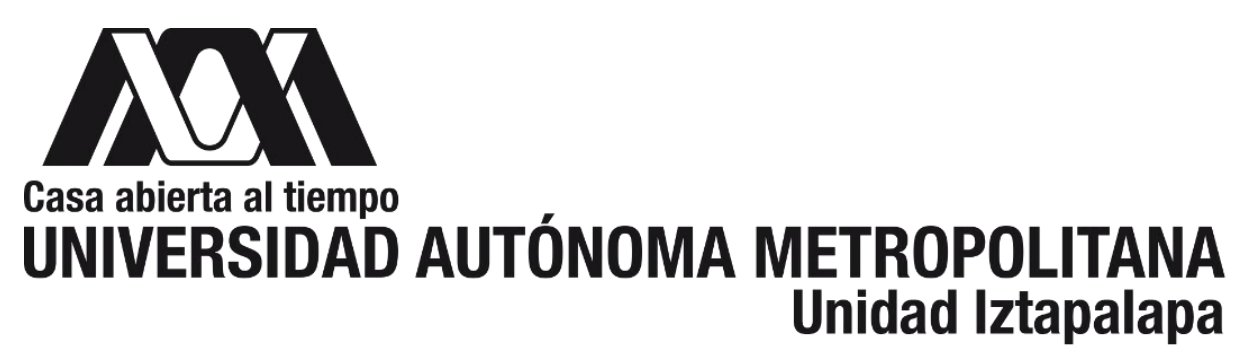

Producción de hidrógeno por un cultivo fotoheterótrofo de BPNS usando efluentes de fermentación oscura como sustrato.

\author{
Tesis que presenta: \\ M.C. Virginia Montiel Corona \\ Para obtener el grado de \\ DOCTORA EN BIOTECNOLOGÍA
}

Director de tesis: Dra. Marcia Guadalupe Morales Ibarría Asesor de tesis: Dr. Sergio Revah Moiseev Asesor de tesis: Dra. Elvia Inés García Peña 
El Doctorado en Biotecnología de la Universidad Autónoma Metropolitana pertenece al Programa Nacional de Posgrados de Calidad (PNPC) del Consejo Nacional de Ciencia y Tecnología (CONACyT), con la referencia 001466

Esta tesis se llevó a cabo en el Laboratorio de Emisiones gaseosas W-007 del Departamento de Biotecnología de la Universidad Autónoma Metropolitana Unidad Iztapalapa. Fue financiado a través de la beca número 209778 otorgada por el CONACyT. 
El Honorable Jurado designado por la División de Ciencias Biológicas y de la Salud de la Universidad Autónoma Metropolitana unidad Iztapalapa aprobó la tesis

\title{
Producción de hidrógeno por un cultivo fotoheterótrofo de BPNS usando efluentes de
} fermentación oscura como sustrato

\author{
Que presentó \\ M. C. Virginia Montiel Corona \\ Comité tutoral \\ Dra. Marcia Guadalupe Morales Ibarría \\ Directora, UAM-Cuajimalpa \\ Dr. Sergio Revah Moiseev \\ Asesor, UAM-Cuajimalpa \\ Dra. Elvia Inés García Peña \\ Asesora, Unidad Profesional Interdisciplinaria de Biotecnología -IPN
}

\section{H. Jurado}

Presidente: Dr. Sergio Revah Moiseev

Secretario: Dra. Flor de María Cuervo López

Vocal: Dr. Germán Buitrón Méndez

Vocal: Dr. Ricardo Beristaín Cardoso 


\section{A GRADECIMIENTOS}

A la Universidad Autónoma Metropolitana-unidad Iztapalapa, por ser una sólida plataforma en mi formación profesional y al CONACyT por la beca otorgada para la realización de este trabajo.

A mi directora de tesis, la Dra. Marcia G. Morales Ibarría, por haber aceptado desarrollar este proyecto bajo su supervisión, por siempre apoyarme en la realización del mismo y por sus valiosas observaciones.

A mi asesor de tesis, el Dr. Sergio Revah, por aceptarme en su grupo, por estar siempre pendiente del progreso del proyecto y sus valiosas aportaciones.

A mi asesora de tesis, la Dra. Elvia Inés García Peña, por su apoyo y por la donación de los efluentes de fermentación oscura que sirvieron para la realización de este trabajo.

A la Dra. Sylvie Le Borgne, por el asesoramiento y tiempo dedicado en la caracterización del cultivo IZT por técnicas de biología molecular.

Al Ingeniero Sergio Hernández por su apoyo a lo largo de mi estancia en el laboratorio W-107.

A la Dra. Gloria M. Trejo, por su apoyo en las determinaciones cromatográficas y por su amistad.

A los laboratorios W-104 por permitirme hacer determinaciones de TOC, NT e IC y al W-106 por darme acceso a sus equipos de laboratorio.

A mi esposo, el Dr. José Antonio Guevara, quien siempre me apoyo de forma incondicional tanto en lo personal como académicamente para la realización de este proyecto, y a mi hijo Emiliano por ser mi motivación y soportar mi ausencia, sin ustedes no lo hubiera logrado. 


\section{RESUMEN}

El objetivo de este trabajo fue estudiar la producción de hidrógeno vía foto-fermentación con un cultivo de bacterias púrpuras no del azufre (BPNS) utilizando como sustrato efluentes de fermentación oscura (DFE) y condiciones de operación alternativas que contribuyan a mejorar la producción de $\mathrm{H}_{2}$ y a bajar los costos de operación, como la utilización de un cultivo de BPNS obtenido de cuerpos de aguas residuales, métodos de desgasificación alternos al uso de Ar, incubación en condiciones ambientales, adición de bicarbonato, utilización de ciclos luz-oscuridad, operación en lote secuencial bajo ciclos luz-oscuridad y operación de un fotobiorreactor de $18 \mathrm{~L}$ con agitado intermitente.

Se obtuvo un cultivo de BPNS denominado IZT que tuvo la misma capacidad para producir $\mathrm{H}_{2}$ que el cultivo puro de Rhodobacter capsulatus. La producción más alta de $\mathrm{H}_{2}\left(1478 \pm 17 \mathrm{~mL} \mathrm{H}_{2} \mathrm{~L}^{-1}\right.$ con una remoción de DQO del $89 \%$ ) se obtuvo bajo condiciones controladas de laboratorio por el cultivo IZT con presión reducida y 250 $\mathrm{mg} \mathrm{L}^{-1}$ de $\mathrm{NaHCO}_{3}$, seguido por $R$. capsulatus (1252 $\pm 20 \mathrm{~mL} \mathrm{H}_{2} \mathrm{~L}^{-1}$ con una remoción de DQO del 65\%) bajo las mismas condiciones. La producción de hidrógeno bajo condiciones ambientales fue menor, reduciéndose a $883 \pm 4$ y $866 \pm 46 \mathrm{~mL} \mathrm{H}_{2} \mathrm{~L}^{-1}$ con el cultivo IZT y $R$. capsulatus, respectivamente. La acumulación de poli-3hydroxibutirato (PHB) fue de $5 \%$ en peso para el cultivo IZT y $29 \%$ para $R$. capsulatus.

Utilizando ciclos luz-oscuridad, el cultivo IZT acumuló cantidades similares de $\mathrm{H}_{2}$ bajo iluminación continua y ciclos luz-oscuridad de 60 y 30 minutos. La máxima Pacum $\mathrm{H}_{2}$ por IZT fue de $1340 \mathrm{~mL} \mathrm{H}_{2} \mathrm{~L}^{-1}$ bajo el ciclo de 30 min. $R$. capsulatus alcanzó una Pacum $\mathrm{H}_{2}$ de $720 \mathrm{~mL} \mathrm{H}_{2} \mathrm{~L}^{-1}$ bajo iluminación continua y bajo ciclos luzoscuridad de 60, 30 y 15 minutos la Pacum $\mathrm{H}_{2}$ disminuyó en un 20\%. Ambos cultivos acumularon más PHB bajo

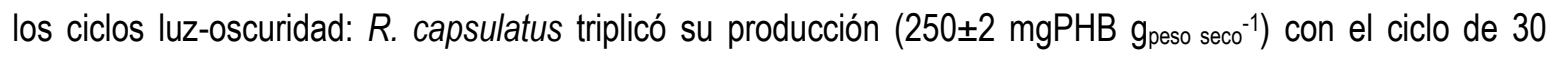
minutos y el cultivo IZT la duplico ( $\left.143 \pm 10 \mathrm{mgPHB}_{\text {peso seco }}{ }^{-1}\right)$ bajo el ciclo de 15 minutos.

Posteriormente se llevó a cabo la producción de $\mathrm{H}_{2}$ en lote secuencial con ciclos luz-oscuridad y el cultivo IZT. Los mejores resultados se presentaron en los tratamientos con un TRH de 15 días y un volumen de recambio de $50 \%$. El tratamiento bajo ciclos de 30 min sostuvo una producción de $\mathrm{H}_{2}$ estable por 32 días, acumulando $2400 \mathrm{~mL} \mathrm{H}_{2} \mathrm{~L}^{-1}$. El tratamiento con un patrón de iluminación de 12 horas luz continua y $12 \mathrm{~h}$ con ciclos de luzoscuridad de 30 min se mantuvo en operación por 45 días y durante este tiempo la producción de $\mathrm{H}_{2}$ fue constante acumulando $3200 \mathrm{~mL} \mathrm{H}_{2} \mathrm{~L}^{-1}$, la remoción de DQO se mantuvo alrededor del $60 \%$.

De manera adicional se realizaron experimentos de fermentación oscura utilizando cascarón de huevo como amortiguador de pH. Los DFE obtenidos tuvieron suficiente alcalinidad proveniente del cascarón de huevo, lo cual permitió utilizarlos sin la adición de buffer y bicarbonato en foto-fermentación.

Finalmente la producción de $\mathrm{H}_{2}$ en el fotobiorreactor plano escala de $18 \mathrm{~L}$ logró alcanzar los rendimientos de producción de $\mathrm{H}_{2}$ (1153 $\mathrm{mL} \mathrm{H}_{2} \mathrm{~L}^{-1}$ en 12 días) que se obtuvieron en los ensayos realizados en botellas serológicas de $120 \mathrm{~mL}$ en lote mediante la agitación intermitente del medio por recirculación a un flujo de 750 $\mathrm{mL} \min ^{-1}$ por seis minutos cada 1.5 horas.

Con respecto a la identidad de los microorganismos constituyentes del cultivo IZT, se encontró que éste está constituido principalmente por una bacteria con $99 \%$ de similitud a $R$. palustris DX1.

De este trabajo se puede concluir que es posible la utilización del cultivo IZT y presión reducida en lugar de una cepa de colección y argón para mejorar la producción de $\mathrm{H}_{2}$. Además, la utilización de ciclos luz-oscuridad, agitación intermitente y la recuperación de PHB pueden contribuir a bajar los costos de operación. 


\section{A B S TRACT}

The objective of this work was to study hydrogen production via photo-fermentation with a purple nonsulfur bacteria (BPNS) culture, using dark fermentation effluent (DFE) as substrate and alternative operating conditions that contribute to improving the hydrogen production and lower operating costs, as the use of an BPNS culture obtained from wastewater bodies, degassing methods alternative to using $\mathrm{Ar}$, incubation under ambient conditions, addition of bicarbonate, use of light-dark cycles, sequencing batch operation under light-dark cycles and operation of a photobioreactor of $18 \mathrm{~L}$ with intermittent agitation.

The IZT culture had the same capacity to produce $\mathrm{H}_{2}$ than pure Rhodobacter capsulatus culture. The highest production of $\mathrm{H}_{2}\left(1478 \pm 17 \mathrm{~mL} \mathrm{H}_{2} \mathrm{~L}^{-1}\right.$ with a COD removal of $89 \%$ ) was obtained under indoor conditions by the IZT culture with reduced pressure and $250 \mathrm{mg} \mathrm{L}^{-1} \mathrm{NaHCO}_{3}$, followed by $R$. capsulatus (1252 $\pm 20 \mathrm{~mL} \mathrm{H}_{2} \mathrm{~L}^{-1}$ with a COD removal of $65 \%$ ) under the same conditions. Outdoor $\mathrm{H}_{2}$ production was reduced to $883 \pm 4$ and $866 \pm 46 \mathrm{~mL} \mathrm{H} 2 \mathrm{~L} \_1$ with IZT culture and $R$. capsulatus, respectively. Poly-3-hydroxybutyrate (PHB) accumulstion was $5 \%$ by weight for IZT and $29 \%$ by weight for $R$. capsulatus.

Using light-dark cycles, IZT culture accumulated similar amounts of $\mathrm{H}_{2}$ under continuous lighting and

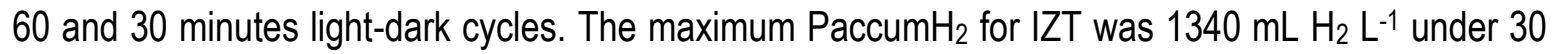
min cycle. R. capsulatus achieved $\mathrm{PaccumH}_{2}$ of $720 \mathrm{~mL} \mathrm{~L}^{-1}$ under continuous illumination and under light-dark cycles of 60,30 and 15 minutes the $\mathrm{PaccumH}_{2}$ decreased by $20 \%$. Both cultures accumulated more PHB under the light-dark cycles: $R$. capsulatus tripled its production (250 \pm 2 $\left.\mathrm{mgPHB} \mathrm{gdw}^{-1}\right)$ with the cycle of 30 minutes and IZT culture doubled it $\left(143 \pm 10 \mathrm{mgPHB} \mathrm{gdw}^{-1}\right)$ under the 15 minute cycle.

Subsequently $\mathrm{H}_{2}$ production was conducted in sequencing batch mode with light-dark cycles using IZT culture. Best results were presented in treatments with a HRT of 15 days and a recharge volume of $50 \%$. Treatment under cycles of 30 min held a stable production of $\mathrm{H}_{2}$ for 32 days, accumulating 2400 $\mathrm{mL} \mathrm{H} \mathrm{L}^{-1}$. Treatment with a pattern 12 hours continuous light and $12 \mathrm{~h}$ light-dark cycles of $30 \mathrm{~min}$ remained in operation for 45 days and during this time the $\mathrm{H}_{2}$ production was constant accumulating $3200 \mathrm{~mL} \mathrm{H}_{2} \mathrm{~L}^{-1}$. COD reduction remained around $60 \%$.

Additionally dark fermentation experiments using egg shell as a pH buffer were performed. DFE had sufficient alkalinity from the eggshell, allowing its use without adding any buffer or bicarbonate for photo-fermentation.

Finally $\mathrm{H}_{2}$ production in the $18 \mathrm{~L}$ plane photobioreactor, reached the same $\mathrm{H}_{2}$ production $(1160 \mathrm{~mL}$ $\mathrm{H}_{2} \mathrm{~L}^{-1}$ in 12 days) obtained in the $120 \mathrm{~mL}$ serological bottles tests performed in batch, using intermittent agitation produced by means of recirculating flow of $750 \mathrm{ml} \mathrm{min}^{-1}$ for six minutes every 1.5 hours.

With regard to the identity of the IZT culture constituents microorganisms, it was found that it is mainly constituted by a bacterium with $99 \%$ similarity to $R$. palustris DX1.

It can be concluded from this work that it is possible to use IZT and reduced pressure rather than a collection pure culture and argon to improve the $\mathrm{H}_{2}$ production. Furthermore, the use of light-dark cycles, intermittent agitation and recovery of PHB can help lower operating costs. 


\section{PRESENTACIÓN DEL DOCUMENTO}

Este trabajo de tesis consiste de seis capítulos y a continuación se describe que se presenta en cada uno de ellos. En el capítulo 1 se presenta la introducción que expone la problemática y las ventajas del $\mathrm{H}_{2}$ como fuente alterna de energía, y en el marco teórico se presentan los fundamentos sobre la producción de $\mathrm{H}_{2}$ por fermentación oscura y foto-fermentación. Este capítulo también contiene el planteamiento de la investigación, hipótesis, objetivos y estrategia experimental global. Los resultados se presentan entre el capítulo 2 y 6 , en donde cada capítulo plantea su introducción, los antecedentes, la problemática y objetivos del capítulo, posteriormente materiales, métodos y resultados específicos sobre los factores estudiados.

En el capítulo 2 se estudian el efecto de cuatro factores: tipo de inóculo, métodos de desgasificación, condiciones de incubación y adición de bicarbonato sobre la producción de $\mathrm{H}_{2}$ por el cultivo IZT y la cepa Rhodobacter capsulatus usando un efluente de fermentación oscura no estéril (DFE-UPIBI) como sustrato. En el capítulo 3 el efecto de la iluminación bajo ciclos luz-oscuridad sobre la producción de $\mathrm{H}_{2}$ y PHB por los cultivos IZT y $R$. capsulatus. El Capítulo 4 muestra los resultados sobre la identificación de los microorganismos presentes en el cultivo IZT y la producción de $\mathrm{H}_{2}$ en lote secuencial bajo ciclos luz-oscuridad empleando el cultivo IZT como inóculo.

Posteriormente, en el capítulo 5 se presentan los experimentos de fermentación oscura para producción de $\mathrm{H}_{2}$ y obtención de efluentes de fermentación oscura (DFE-UAM), caracterización y uso en fotofermentación. El capítulo 6 describe las consideraciones de diseño que se tomaron en cuenta para la construcción y arranque del fotobiorreactor plano de $18 \mathrm{~L}$ que se empleó para hacer pruebas de producción de $\mathrm{H}_{2}$. Finalmente se presentan las conclusiones generales y perspectivas de este trabajo de tesis. 


\section{INDÍCE}

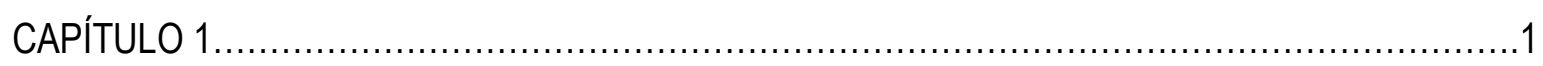

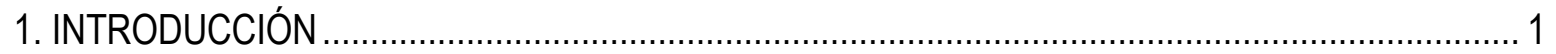

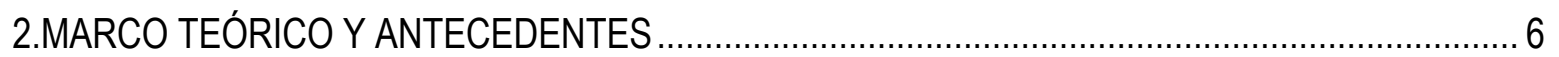

2.1. Producción de hidrógeno por fermentación oscura............................................................ 6

2.2. Factores que afectan la producción de hidrógeno por fermentación oscura.............................. 13

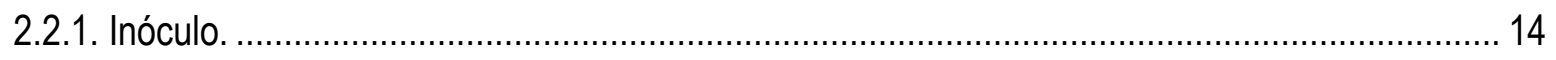

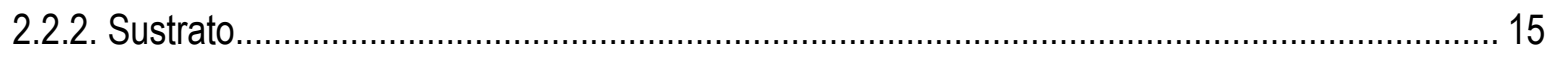

2.2.3. pH del medio

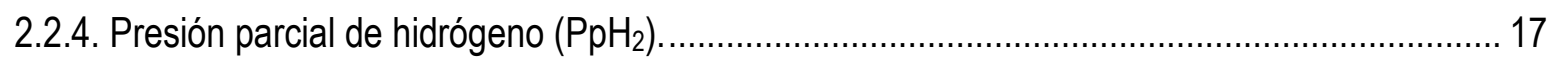

2.3. Producción de hidrógeno por fermentación luminosa ............................................................. 17

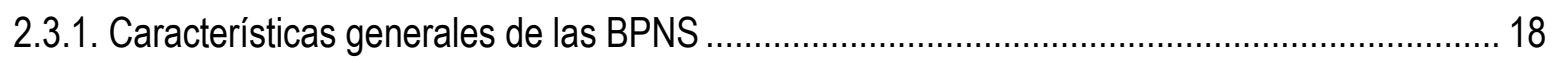

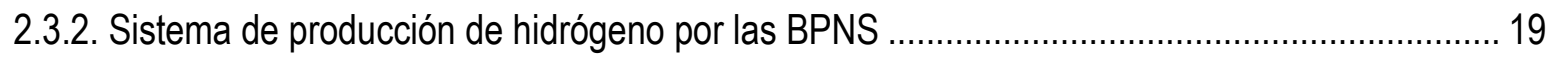

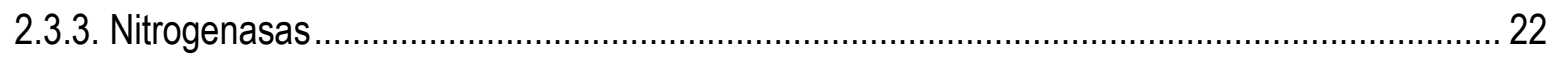

2.3.4. Hidrogenasa

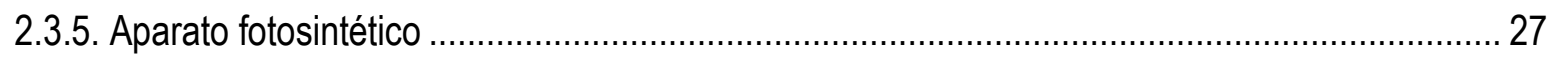

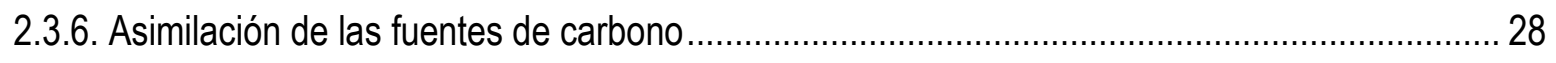

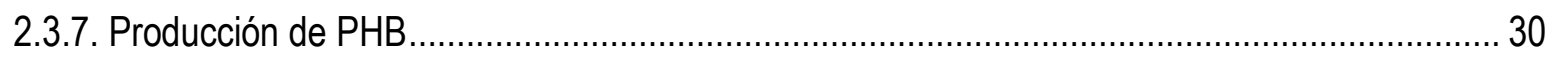

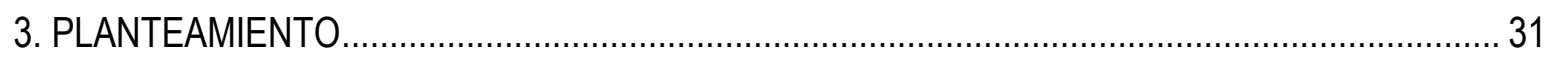

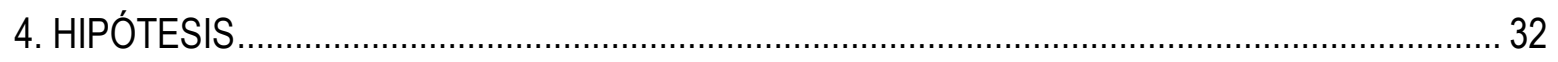

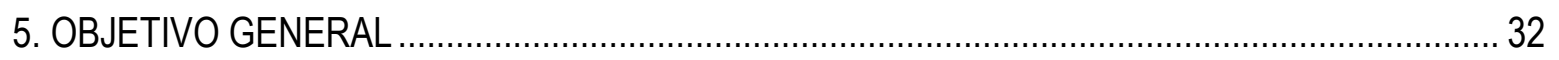

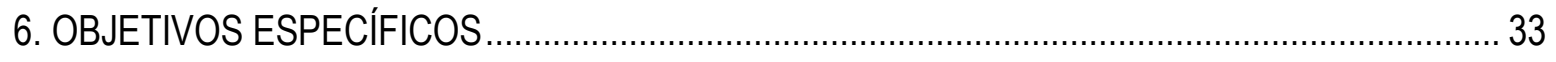

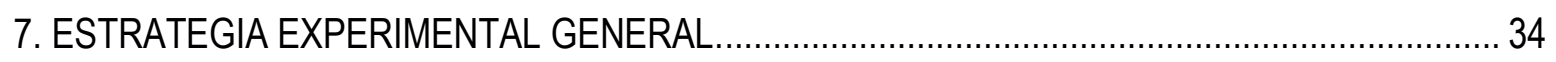

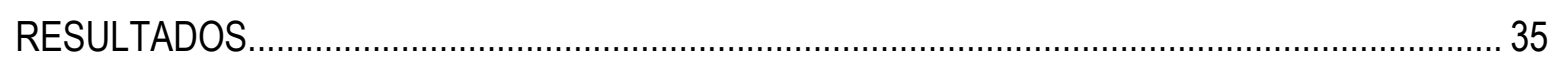

CAPÍTULO 2

Producción de hidrógeno por un cultivo fotoheterótrofo usando un efluente de fermentación oscura como sustrato: efecto del método de purgado, adición de bicarbonato, e incubación bajo condiciones

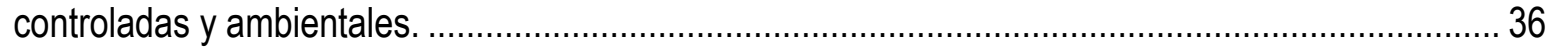

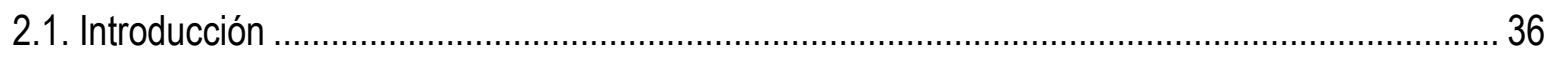

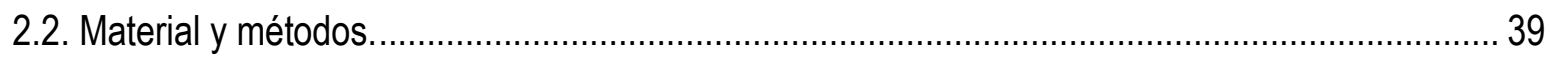

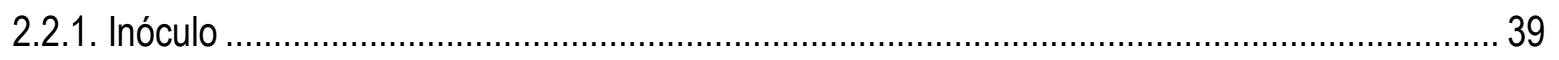

2.2.2. Preparación del medio Pfennig para la propagación y conservación de los cultivos ............... 40

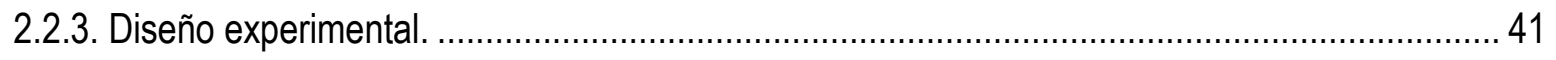

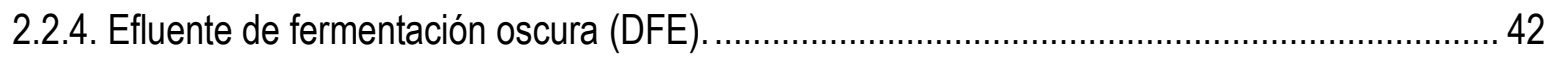


2.2.5. Pruebas de producción de hidrógeno en lote..................................................................... 43

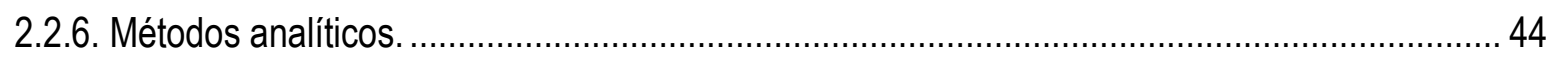

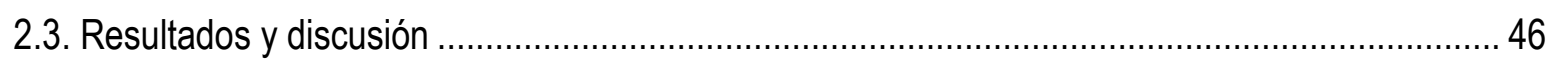

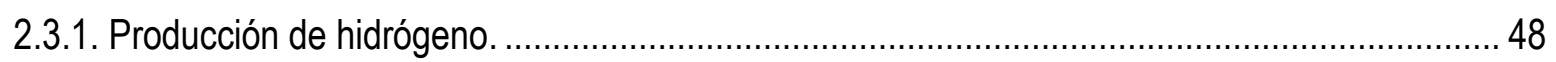

2.3.1.1. Efecto del inóculo sobre la producción de hidrógeno ................................................... 48

2.3.1.2. Efecto del método de purgado del headspace sobre la producción de hidrógeno. ...............51

2.3.1.3. Efecto de la adición de $\mathrm{NaHCO}_{3}$ sobre la producción de hidrógeno ...................................54

2.3.1.4. Efecto de las condiciones de incubación sobre la producción de hidrógeno. .......................56

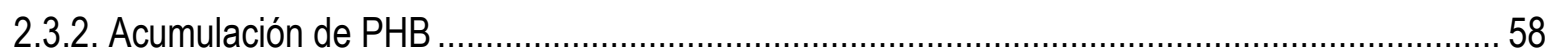

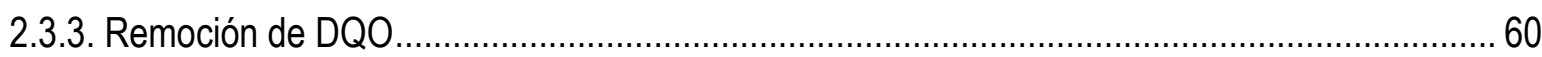

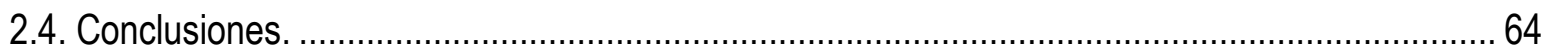

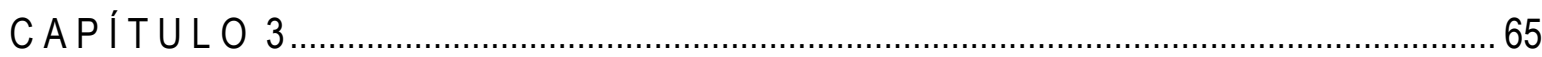

Efecto de ciclos luz - oscuridad sobre la producción de hidrógeno y PHB por un cultivo fotoheterótrofo y $R$. capsulatus empleando un efluente de fermentación oscura como sustrato ........65

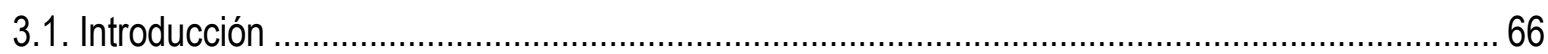

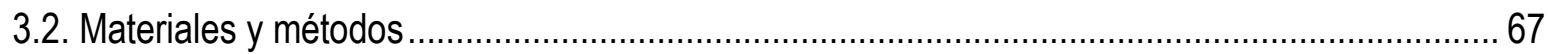

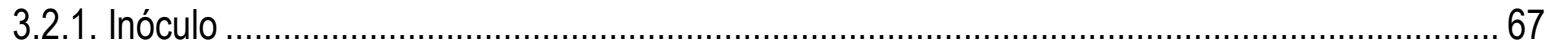

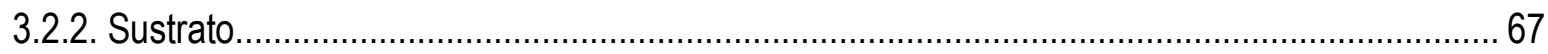

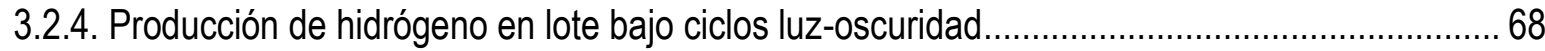

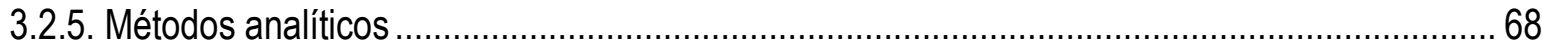

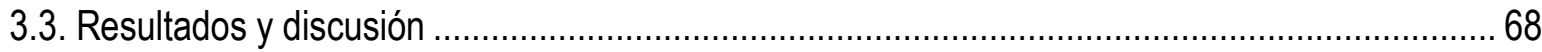

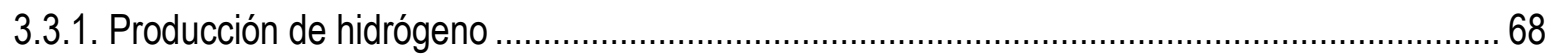

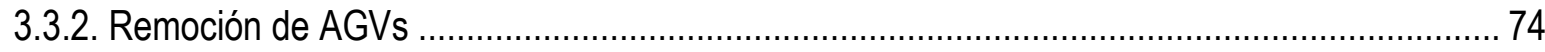

3.3.3. Remoción de DQO

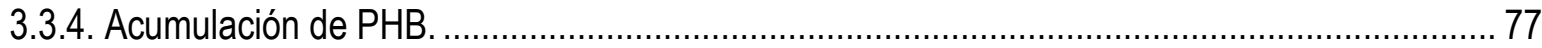

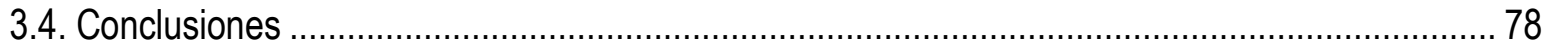

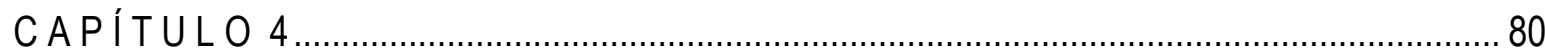

Producción de hidrógeno en lote secuencial bajo ciclos de luz-oscuridad por un cultivo

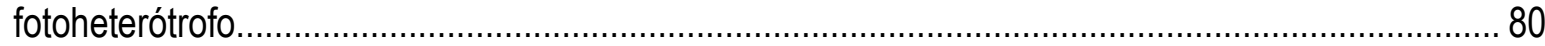

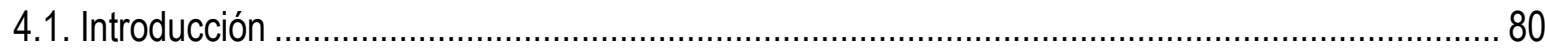

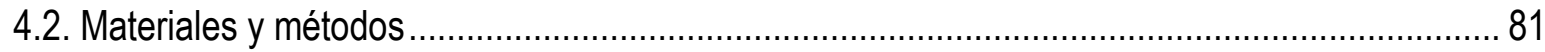

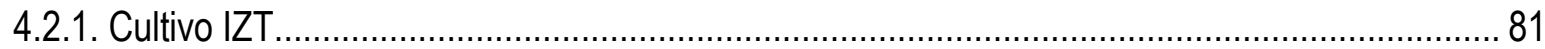

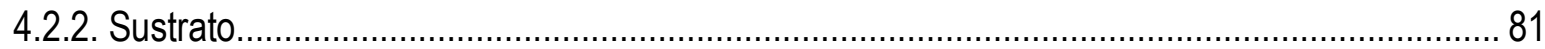

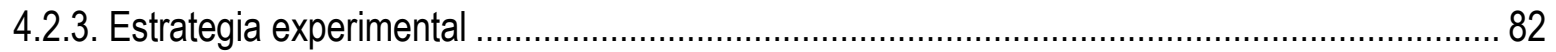

4.2.4. Extracción de ADN y análisis del cultivo IZT por DGGE. .................................................... 82 


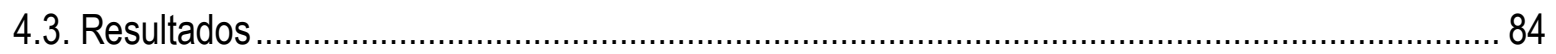

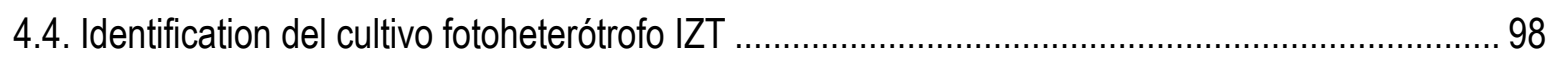

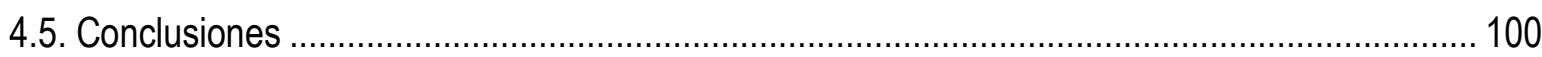

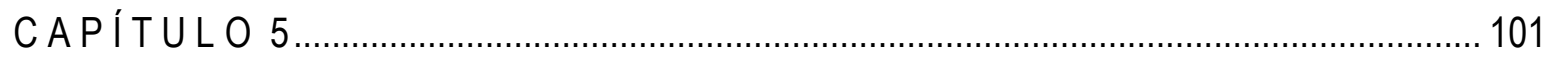

Obtención de efluentes de fermentación oscura y su utilización para la producción de hidrógeno . 101

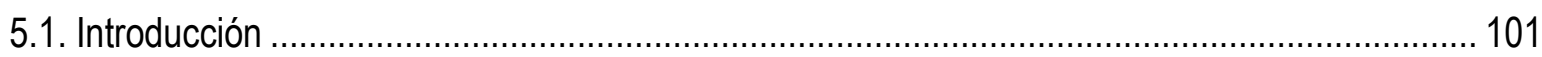

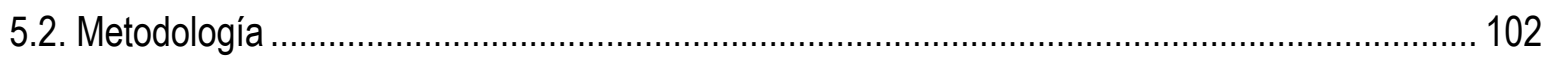

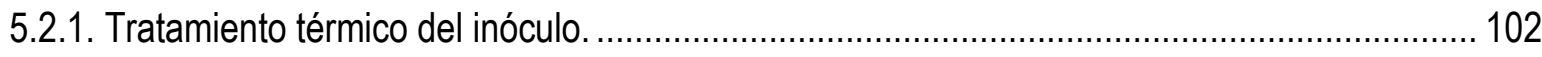

5.2.2. Sustrato y harina de cascarón de huevo ....................................................................... 103

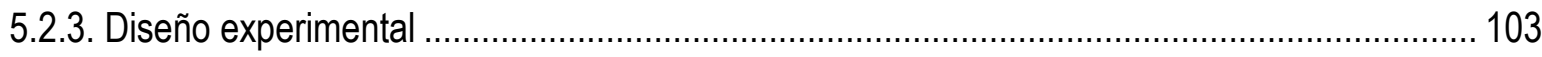

5.2.4. Producción de hidrógeno por fermentación oscura en lote................................................ 104

5.2.5. Producción de hidrógeno por fermentación oscura en reactor de $5 \mathrm{~L}$................................. 104

5.2.6. Producción de $\mathrm{H}_{2}$ por fotofermentación con DFE-UAM .................................................. 105

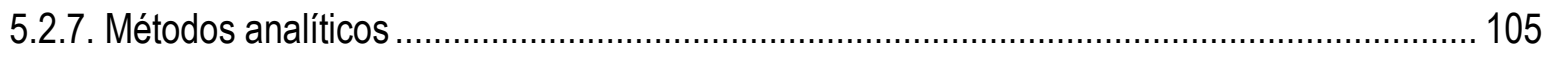

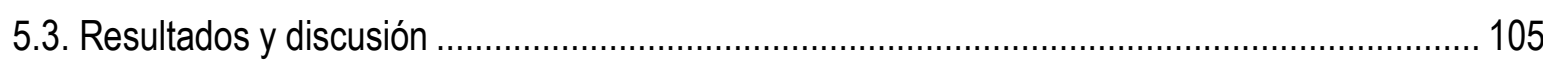

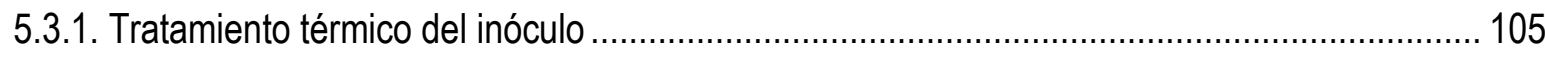

5.3.2. Cascarón de huevo como amortiguador de pH............................................................ 106

5.3.3. Suplementación con nutrientes................................................................................ 111

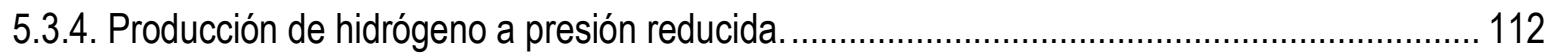

5.3.5. Producción de hidrógeno por fermentación oscura en reactor de $5 \mathrm{~L}$............................... 112

5.4. Resultados para las pruebas de fotofermentación con DFE-UAM........................................ 113

5.4.1. Caracterización de los DFE-UAM ............................................................................ 113

5.4.2. Producción de hidrógeno ....................................................................................... 114

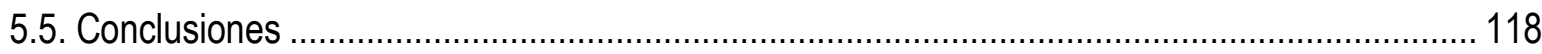

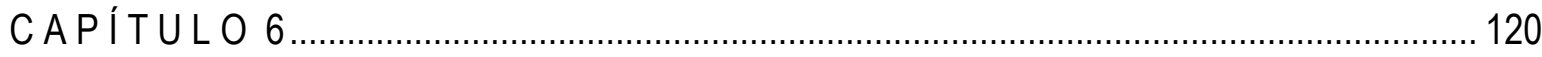

Construcción, arranque y operación de un fotobiorreactor de 18 litros para la producción de

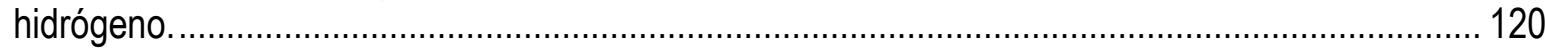

6.1. Introducción ....................................................................................................... 120

6.2. Factores de diseño para la construcción del fotobiorreactor .................................................. 123

6.2.1. Configuración y material de construcción ...................................................................... 123

6.2.2. Sistema de iluminación y control de temperatura. ......................................................... 126

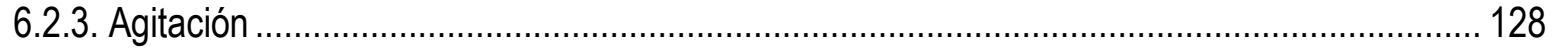

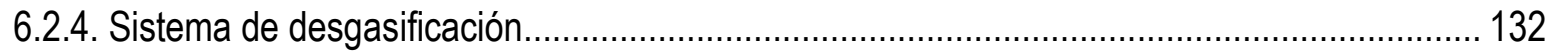

6.3. Ensayos de producción de hidrógeno en el fotobiorreactor de $18 \mathrm{~L}$. ..................................... 132

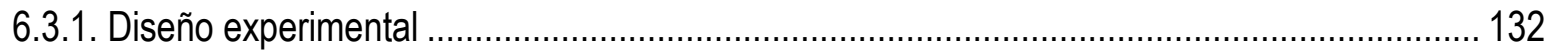




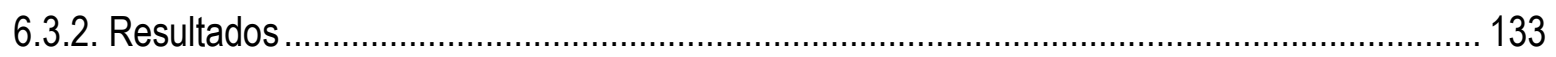

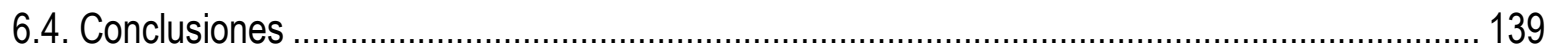

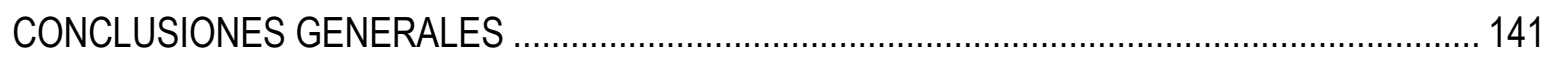

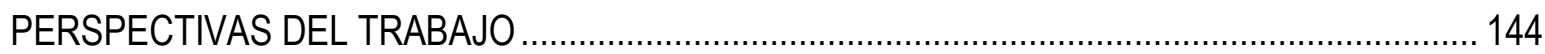

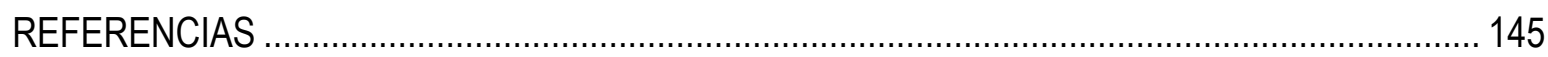

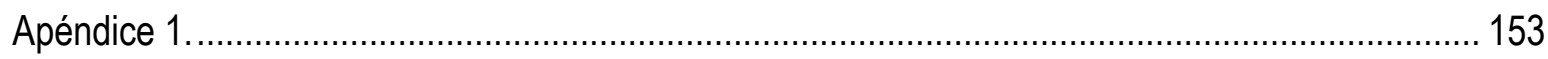

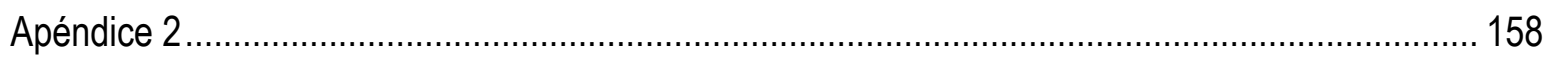

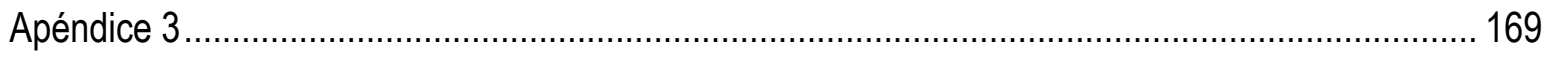

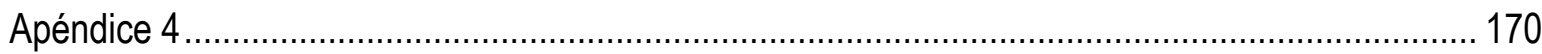




\section{CA PÍT UL 01}

\section{INTRODUCCIÓN}

La investigación en fuentes alternativas de energía ha tomado gran importancia en años recientes debido a los problemas de contaminación ambiental derivados de la utilización de los combustibles fósiles como fuente principal de energía y a la inestabilidad en el precio de los hidrocarburos (Kapdan \& Kargi, 2006; Lin et al., 2012; Montiel-Corona et al., 2015).

La disminución de las reservas de petróleo debido al aumento de la demanda de energía por el crecimiento poblacional y las economías emergentes ha provocado inseguridad política en las regiones productoras como Asia Central, Mundo Árabe y América Latina (Bleischwitz et al., 2010; Kothari et al., 2012; Kothari et al 2010). El temor de que algunos países puedan utilizar sus exportaciones de petróleo y gas como instrumento político hacen que se intensifiquen en los esfuerzos para reducir la dependencia de las importaciones de combustible en muchos países (Bleischwitz et al., 2010). Las reservas de petróleo conocidas son recursos limitados y se estima que después del 2070 su producción declinará (Mohr et al., 2015) y, aunque por algunas décadas más seguirán siendo

la base del desarrollo económico mundial (Studer et al., 2014), la necesidad de seguridad en el suministro de energía a precios accesibles y previsibles son motivo de una transformación hacia un sistema energético sostenible.

Las emisiones de $\mathrm{CO}_{2}$ que se encuentran ligadas con la quema de combustibles fósiles se han incrementado de manera sostenida lo que ha provocado problemas de contaminación ambiental y son 
responsables en gran medida de un acentuado efecto invernadero y cambio climático. Durante el periodo 1990-2012, las emisiones mundiales de $\mathrm{CO}_{2}$ derivadas del consumo de combustibles fósiles aumentó alrededor de un $57 \%$ de acuerdo con el último informe publicado por la International Energy Agency (IEA) en el año 2012. Cinco países fueron responsables del $58 \%$ del $\mathrm{CO}_{2}$ emitido a nivel mundial por consumo y quema de combustibles fósiles: Estados Unidos, China, Rusia, Japón e India (IEA, 2012).

En nuestro país y de acuerdo con el Instituto Nacional de Estadística y Geografía (INEGI) (2012), entre 1990 y 2010 se incrementaron las emisiones nacionales de casi todos los gases de efecto invernadero, resaltando, por su importancia en volumen, las de $\mathrm{CO}_{2}$ que aumentaron $24 \%$, el $\mathrm{CH}_{4}$ que tuvo un incremento de $60 \%$ y el $\mathrm{N}_{2} \mathrm{O}$ que aumentó $23 \%$.

Por otro lado, un gran problema al que se enfrentan las sociedades actuales, pero que puede contribuir a la solución de la crisis energética, es la generación de residuos (sólido/líquido) que va al unísono del aumento de la población en todo el mundo. Durante el último siglo, el crecimiento continuo de la población y la industrialización ha provocado la generación de enormes cantidades de residuos y la degradación de diversos ecosistemas (Chan et al., 2009).

La generación de residuos sólidos urbanos (RSU) en México se ha incrementado notablemente en los últimos años, tan sólo entre 2003 y 2011 creció 25\%, como resultado principalmente del crecimiento urbano, el desarrollo industrial y el cambio en los patrones de consumo. Aproximadamente el $50 \%$ de los RSU en nuestro país son materia orgánica (Guevara \& Montiel, 2014), pero la mayor parte de esta materia orgánica es susceptible de tratarse por métodos biológicos para reducir las emisiones de $\mathrm{CO}_{2}$ y obtener energía (Chan et al., 2009).

Los residuos procedentes del sector agrícola (desechos vegetales y animales), industrial (refinería de azúcar, residuos lácteos, residuos confitería, pasta, papel, etc.) y residencial (residuos de cocina y de jardín) son posibles fuentes de energía renovables y sostenibles (Kothari et al., 2010). En la figura 1 
se presenta el potencial de recuperación energética en forma de biogás de diferentes residuos orgánicos procedentes del sector municipal e industrial.

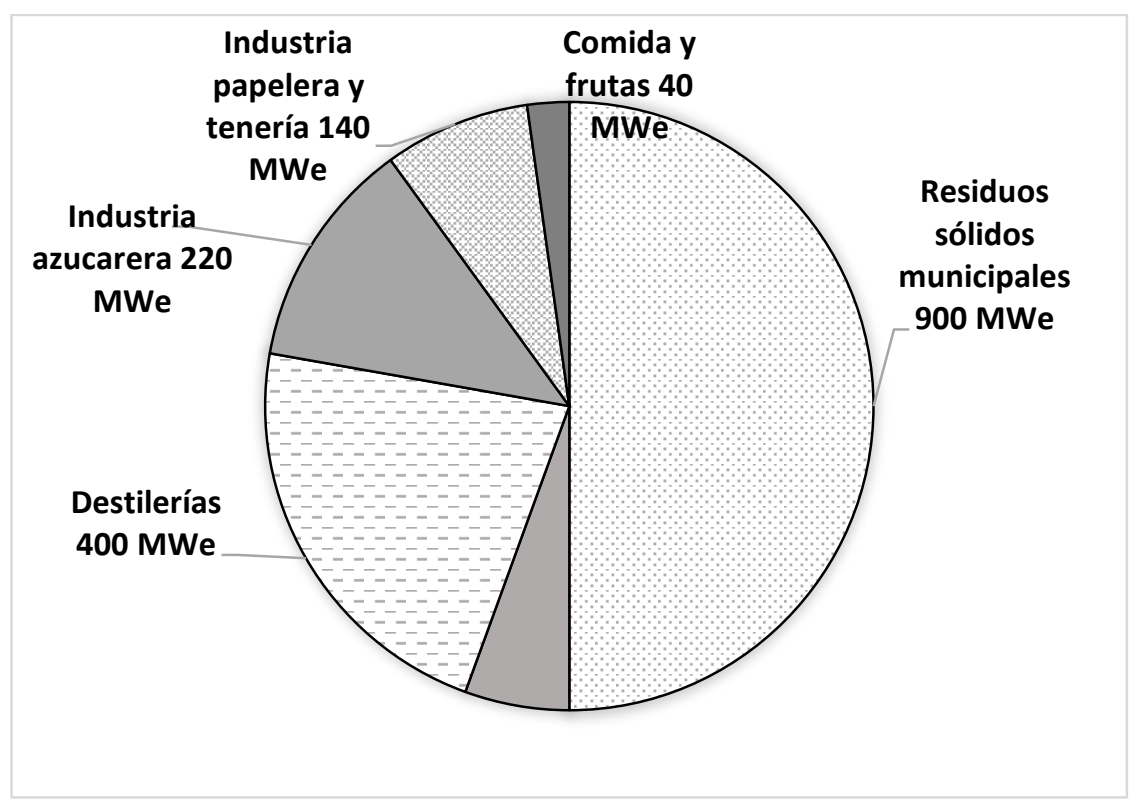

Figura 1. Potencial de recuperación energética en Megavatios eléctricos (MWe) de diferentes residuos procedentes del sector urbano e industrial. Fuente: (Kothari et al., 2010).

El hidrógeno es una de las fuentes alternas de energía más prometedoras para el futuro, de acuerdo a un número importante de reportes oficiales reconocidos y artículos publicados en importantes revistas de investigación científica (Claassen et al., 2010) debido a las siguientes ventajas:

- El hidrógeno es un buen vector energético, que en corto plazo puede ocupar un lugar importante como un medio de almacenamiento y transporte de energía renovables (Balat \& Balat, 2009).

- Su contenido energético por unidad de masa es más alto que cualquier otro combustible convencional (143 kJ energía/g H2) (McKinlay \& Harwood, 2010). 
- Durante su utilización no se emite $\mathrm{CO}_{2}$ ni algún otro gas contaminante, el único subproducto es agua (Özgür \& Peksel, 2013).

Actualmente el $96 \%$ del hidrógeno que se consume en las industrias agroalimentarias y refinerías se produce por métodos termoquímicos a partir de combustibles fósiles, emitiendo durante su producción la misma cantidad de $\mathrm{CO}_{2}$ que si se quemara directamente el combustible fósil (Balat \& Balat, 2009), por lo que no tiene ventaja ambiental producirlo por esa vía, la única manera de que el hidrógeno pudiera ayudar a mitigar las emisiones de $\mathrm{CO}_{2}$ es que se produzca por métodos amigables con el ambiente. Los métodos biológicos ofrecen alternativas para producir hidrógeno sin una demanda de energía exacerbada y con reducción en las emisiones de $\mathrm{CO}_{2}$.

Uno de los métodos más estudiado sobre la producción biológica de hidrógeno es la fermentación oscura de residuos orgánicos, que además es susceptible de escalarse a nivel industrial (Chang \& Hsu, 2012). Sin embargo, los rendimientos se ven limitados a menos del $30 \%$ principalmente por la producción simultánea de ácidos grasos volátiles (AGVs), que precisan un tratamiento posterior (Sarma, et al., 2015). Dentro de las posibles alternativas para el tratamiento de los efluentes ricos en AGVs el que más se emplea es la digestión anaerobia para producir metano, que tiene un poder calorífico (56 kJ energía/g $\mathrm{CH}_{4}$ ) menor al hidrógeno (142 kJ energía/g $\mathrm{H}_{2}$ ) y su combustión libera $\mathrm{CO}_{2}$ (Sarma et al., 2015).

Otra opción es la foto-fermentación que conlleva una conversión cercana a los valores estequiométricos de los AGVs a hidrógeno, y que se puede llevar a cabo por bacterias púrpuras no del azufre (BPNS). El rendimiento máximo teórico de hidrógeno en la fermentación oscura es 4 mol $\mathrm{H}_{2} / \mathrm{mol}$ glucosa con ácido acético como único subproducto, y este rendimiento puede incrementarse a más de 8 moles $\mathrm{H}_{2} / \mathrm{mol}$ glucosa con la foto-fermentación como etapa adicional (Guwyet al., 2011). El proceso secuencial fermentación oscura - foto-fermentación de residuos orgánicos (ver Figura 2) 
es una vía prometedora para incrementar el rendimiento global de hidrógeno, la recuperación de energía y la disminución de la demanda química de oxígeno (DQO) de los residuos (Kapdan \& Kargi, 2006; Özkan et al., 2012).

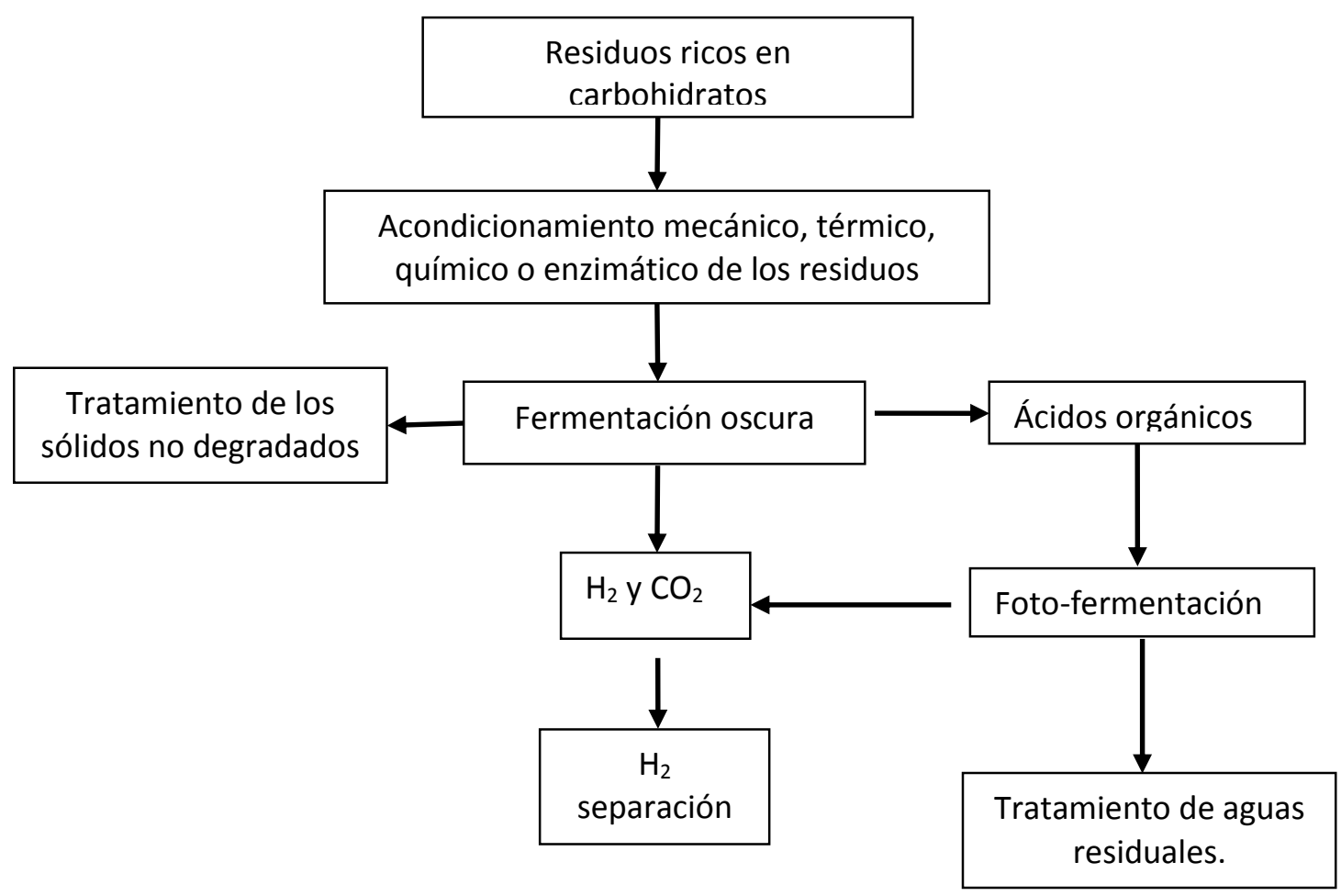

Figura 2. Producción de hidrógeno en un proceso secuencial fermentación oscura-fotofermentación. Adaptado de Kırtay, 2011. 


\section{MARCO TEÓRICO Y ANTECEDENTES}

\subsection{Producción de hidrógeno por fermentación oscura}

Bajo condiciones anaerobias, el hidrógeno se produce como un subproducto durante la conversión de residuos orgánicos en ácidos orgánicos los cuales posteriormente se usan para la generación de metano en el proceso de digestión anaerobia (Kapdan \& kargi, 2006).

La digestión anaerobia es un proceso complejo en el que intervienen diferentes grupos microbianos, de manera coordinada y secuencial, para descomponer la materia orgánica, en ausencia de oxígeno libre. La interacción cooperativa de varios grupos de procariotas permite la formación de hidrógeno y metano a partir de sustancias de elevado peso molecular, tales como polisacáridos, proteínas y grasas (Redondas-Monteserrín, 2013). El proceso de digestión anaerobia se divide en 4 etapas (ver figura 3)(Bouallagui et al.,2005):

1. Hidrólisis: Conversión de biopolímeros no solubles a compuestos orgánicos solubles. La hidrólisis de los biopolímeros complejos es llevada a cabo por enzimas extracelulares excretadas por bacterias celulolíticas, bacterias hidrolíticas y bacterias acidógenas, que permiten la ruptura de los polímeros orgánicos hasta subunidades más pequeñas fácilmente transportadas al interior celular (Hiligsmann et al., 2011; Redondas-Monteserrín, 2013).

2. Acidogénesis: Conversión de los compuestos orgánicos solubles en ácidos grasos volátiles, hidrógeno y $\mathrm{CO}_{2}$. Las bacterias acidogénicas transforman la materia orgánica disuelta principalmente 
en ácidos grasos volátiles (AGVs) tales como el acetato, el propionato, el butirato y el sucinato, así como pequeñas cantidades de ácido láctico y etanol, dióxido de carbono e hidrógeno (Bouallagui et al., 2005; Hiligsmann et al., 2011; Redondas-Monteserrín, 2013).

3. Acetogénesis. Conversión de los ácidos grasos volátiles con tres o más carbonos en ácido acético, hidrógeno y $\mathrm{CO}_{2}$. Esta conversión sólo es posible si la presión parcial de hidrógeno se encuentra en valores bajos, con presiones parciales menores de $10^{-3} \mathrm{~atm}$. Aquí también pueden actuar bacterias homoacetogénicas que convierten $\mathrm{CO}_{2}$ e hidrógeno a ácido acético (Clark et al., 2012).

4. Metanogénesis: Conversión de ácido acético y $\mathrm{CO}_{2}$ en $\mathrm{CH}_{4}$. En esta etapa están implicadas dos tipos de reacciones, aquellas en las que el dióxido de carbono e hidrógeno se combinan para producir metano y agua (metanogénesis hidrogenotrófica), y las que convierten el ácido acético en metano y dióxido de carbono (metanogénesis acetoclástica) (Redondas-Monteserrín, 2013).

La fase acidogénica de la digestión anaerobia es lo que se denomina fermentación oscura y durante este proceso las bacterias fermentativas producen hidrógeno sin la presencia de luz.

Los microorganismos productores de hidrógeno en la fermentación oscura pueden clasificarse en dos grupos: (a) anaerobios facultativos (o bacterias entéricas como Escherichia coli, Enterobacter y Citrobacter o del género Bacillum) y, (b) anaerobios estrictos (del género Clostridium) que pueden obtener energía por fermentación (en ausencia de oxígeno) produciendo hidrógeno (Kumar-Khanal, 2009). Esta producción con frecuencia se asocia a la presencia de una ferrodoxina, un transportador de electrones de muy bajo potencial, y una hidrogenasa que cataliza el transporte de electrones desde la ferrodoxina a los protones (Madigan et al., 2004). 


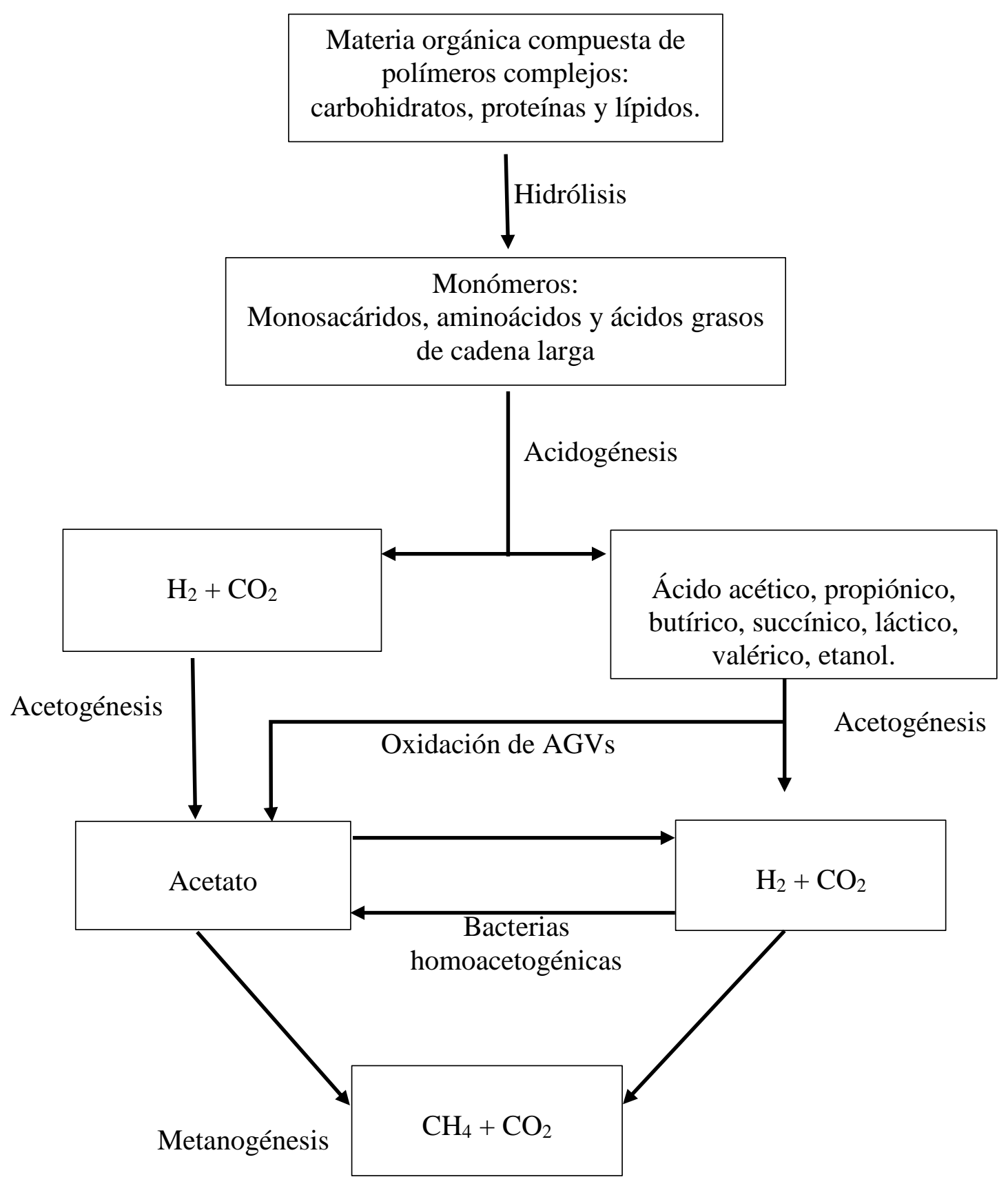

Figura 3. Proceso de digestión anaerobia. Adaptado de Ghimire et al., 2015; Kothar et al., 2014. 
En la mayoría de los sistemas biológicos, el hidrógeno se produce por el metabolismo anaerobio del piruvato formado durante el catabolismo de los diversos sustratos orgánicos. Los azúcares simples como la glucosa se metabolizan para generar piruvato a través de las rutas de Embden-MeyerhoffParnas (glicólisis) y la Entner-Doudoroff. El piruvato se transforma a acetil-coenzima, de la cual se puede derivar el adenosin trifosfato (ATP). Tres enzimas compiten por el piruvato: piruvato-formiatoliasa (PFL), piruvato-ferredoxina-óxido-reductasa (PFOR) y la lactato deshidrogenasa fermentativa (LDH). El rendimiento de producción de hidrógeno depende del destino del piruvato, el cual es diferente entre especies debido a las diferencias en la actividad de las enzimas PFL, PFOR y LDH, y a la presencia de diversas combinaciones de éstas. Los microorganismos facultativos generan hidrógeno utilizando el sistema PFL, mientras que los anaerobios obligados lo obtienen utilizando el sistema PFOR. El rendimiento máximo para las bacterias entéricas es de 2 mol de hidrógeno y de 4 mol de hidrógeno/mol glucosa para los clostridios (Hallenbeck \& Benemann, 2002; Kumar-Khanal, 2009; Redondas-Monteserrín, 2013; Redwood et al., 2009).

En consorcios, las bacterias entéricas y clostridios pueden coexistir y su abundancia dependerá de su competitividad por los sustratos disponibles y las condiciones ambientales. Se reporta que más del $70 \%$ de los microorganismos presentes en cultivos que producen hidrógeno por fermentación oscura pertenecen al género Clostridium. Los Clostridios son capaces de utilizar diferentes sustratos orgánicos como carbohidratos, aminoácidos, purinas y pirimidinas por una variedad de rutas metabólicas (Kumar-Khanal, 2009).

La ruta de producción de hidrógeno por Clostridios usando glucosa como sustrato modelo se muestra en la Figura 4. Los sustratos orgánicos como la glucosa se metabolizan para formar piruvato a través de la glicólisis. Los Clostridios fragmentan el piruvato en acetil coenzima A (acetil-CoA) a través del sistema enzimático PFOR. Los electrones generados se transfieren a la ferredoxina $(\mathrm{Fd})$ que se reduce $(\mathrm{Fd}(\mathrm{red}))$. Debido al bajo potencial redox de la $\mathrm{Fd}(\mathrm{red})$, una hidrogenasa puede oxidarla generando 
hidrógeno (Figura 4, Ruta A). Además, dos moles de NAD+ (nicotinamida adenín dinucleótido) son reducidos durante la descarboxilación oxidativa del piruvato a NADH, el cual proporciona equivalentes reductores para la síntesis de hidrógeno en la segunda ruta metabólica. Así, en la segunda ruta el NADH formado durante la glucólisis y la descarboxilación oxidativa del piruvato se utiliza para producir hidrógeno por medio de la hidrogenasa (Figura 4, Ruta B), permitiendo a su vez regenerar el NAD+ (Chen et al., 2006). En este paso el NADH es oxidado por la ferredoxina a NAD+y de nuevo se puede producir hidrógeno por la oxidación de la Fd(red) vía hidrogenasa. Sin embargo, esta oxidación de NADH sólo es termodinámicamente favorable cuando la presión parcial de hidrógeno $\left(\mathrm{PpH}_{2}\right)$ es menor a $6 \times 10^{-4}$ atm (60 Pa) (Redondas-Monteserrín, 2013). Por el contrario, la producción de hidrógeno vía oxidación del piruvato y ferredoxina es favorable a $\mathrm{PpH}_{2}$ superiores a $0.3 \mathrm{~atm}\left(3 \times 10^{4} \mathrm{~Pa}\right)$. A temperaturas elevadas, las condiciones termodinámicas son favorables para la producción adicional de hidrógeno a través de la reducción del NADH (Chen et al., 2006; Kumar-Khanal, 2009; Ntaikou et al., 2010; Redondas-Monteserrín, 2013). 


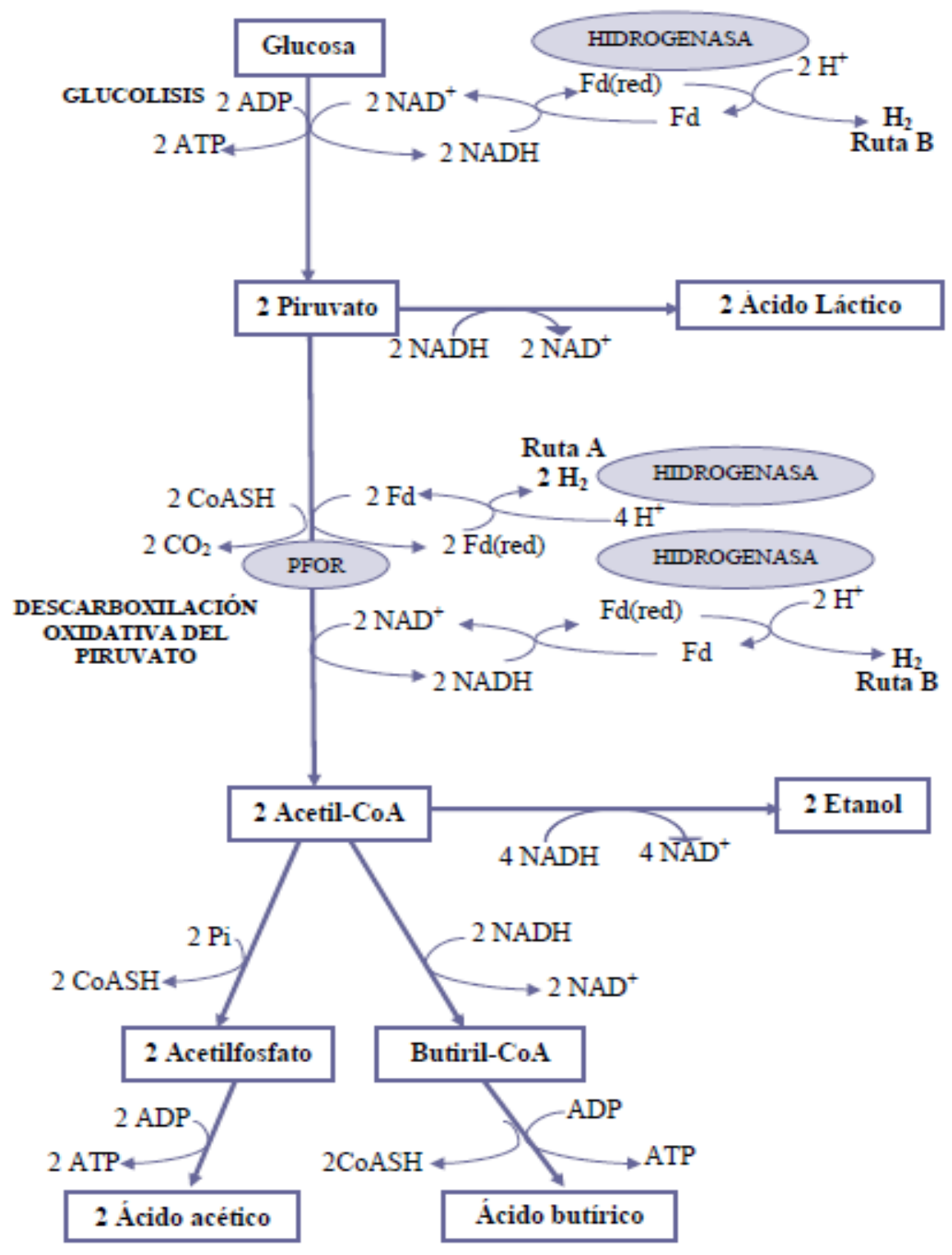

Figura 4. Rutas metabólicas de producción de hidrógeno por Clostridium butyricum durante la fermentación oscura. Tomada de Chen et al., 2006 \& Redondas-Monteserrín, 2013. 
Las diferentes reacciones que se pueden producir con la combinación de las diferentes rutas metabólicas de la fermentación oscura se presentan en la Tabla 1.

Tabla 1. Reacciones netas resultado de las rutas metabólicas de la fermentación oscura

\begin{tabular}{|c|c|c|}
\hline Reacción & $\begin{array}{c}\Delta G^{\circ}(\mathrm{kJ} / \mathrm{mol}) \\
\text { a } 25^{\circ} \mathrm{C}\end{array}$ & Ec. \\
\hline $\mathrm{C}_{6} \mathrm{H}_{12} \mathrm{O}_{6}+6 \mathrm{H}_{2} \mathrm{O} \rightarrow 6 \mathrm{CO}_{2}+12 \mathrm{H}_{2}$ & 241 & 1 \\
\hline $\mathrm{C}_{6} \mathrm{H}_{12} \mathrm{O}_{6}+2 \mathrm{H}_{2} \mathrm{O} \rightarrow 2 \mathrm{CH}_{3} \mathrm{COOH}+2 \mathrm{CO}_{2}+4 \mathrm{H}_{2}(3 \mathrm{ATP})$ & -184 & 2 \\
\hline $\mathrm{C}_{6} \mathrm{H}_{12} \mathrm{O}_{6} \rightarrow \mathrm{CH}_{3} \mathrm{CH}_{2} \mathrm{CH}_{2} \mathrm{COOH}+2 \mathrm{CO}_{2}+2 \mathrm{H}_{2} \quad(4 \mathrm{ATP})$ & -255 & 3 \\
\hline $\mathrm{C}_{6} \mathrm{H}_{12} \mathrm{O}_{6}+0.5 \mathrm{H}_{2} \mathrm{O} \rightarrow 0.7 \mathrm{CH}_{3} \mathrm{CH}_{2} \mathrm{CH}_{2} \mathrm{COOH}+0.5 \mathrm{CH}_{3} \mathrm{COOH}+2 \mathrm{CO}_{2}+2.5 \mathrm{H}_{2}$ & $-237^{*}$ & 4 \\
\hline $\mathrm{C}_{6} \mathrm{H}_{12} \mathrm{O}_{6}+2 \mathrm{H}_{2} \mathrm{O} \rightarrow \mathrm{CH}_{3} \mathrm{COOH}+\mathrm{CH}_{3} \mathrm{CH}_{2} \mathrm{OH}+2 \mathrm{CO}_{2}+2 \mathrm{H}_{2}$ & $20^{*}$ & 5 \\
\hline $\mathrm{C}_{6} \mathrm{H}_{12} \mathrm{O}_{6}+2 \mathrm{H}_{2} \rightarrow 2 \mathrm{CH}_{3} \mathrm{CH}_{2} \mathrm{COOH}+2 \mathrm{H}_{2} \mathrm{O}$ & $-303^{*}$ & 6 \\
\hline $\mathrm{C}_{6} \mathrm{H}_{12} \mathrm{O}_{6} \rightarrow 2 \mathrm{CH}_{3} \mathrm{CH}_{2} \mathrm{OH}+2 \mathrm{CO}_{2}$ & $-211^{*}$ & 7 \\
\hline $\mathrm{C}_{6} \mathrm{H}_{12} \mathrm{O}_{6} \rightarrow 2 \mathrm{CH}_{3}-\mathrm{CH}(\mathrm{OH})-\mathrm{COOH}$ & & 8 \\
\hline
\end{tabular}

De la ecuación 1 se puede observar que 1 mol de glucosa puede producir hasta 12 moles de hidrógeno. Sin embargo, esta reacción es energéticamente desfavorable $\left(\Delta \mathrm{G}^{0}>0\right)$ y solo podría ocurrir a concentraciones de $\mathrm{H}_{2}$ extremadamente bajas, para desplazar el equilibrio hacia la producción de $\mathrm{H}_{2}$ (De Gioannis et al., 2013). Cuando las rutas metabólicas favorecen solo la producción de ácido acético, se pueden obtener 4 moles de hidrógeno por cada mol de glucosa teóricamente $\left(544 \mathrm{~mL} \mathrm{H}_{2}\right.$ $\mathrm{g}^{-1}$ glucosa a $\left.25^{\circ} \mathrm{C}\right)$ (ecuación 2), pero en la práctica sólo se puede obtener una tercera parte de la producción teórica máxima de hidrógeno, debido a que una parte de los equivalentes reductores del sustrato original permanecen como acetato (De Gioannis et al., 2013; Ghimire et al., 2015). 
Cuando el producto final del metabolismo es ácido butírico el rendimiento es de 2 moles $\mathrm{H}_{2}$ mol-1 $^{-1}$ glucosa $\left(272 \mathrm{~mL} \mathrm{H}_{2} \mathrm{~g}^{-1}\right.$ glucosa a $25^{\circ} \mathrm{C}$ ) (ecuación 3). A menudo ocurre la producción simultánea de acetato y butirato; cuando el ácido butírico es el producto final dominante, la producción de $\mathrm{H}_{2}$ nunca excede $2.5 \mathrm{~mol} \mathrm{H}_{2}$, como se muestra en la ecuación 4 (Ghimire et al., 2015; Kumar-Khanal, 2009). Los rendimientos reales de hidrógeno son más bajos que los rendimientos teóricos debido a que una parte del sustrato se emplea para la producción de biomasa y la degradación de los sustratos puede seguir otras rutas metabólicas sin la producción de hidrógeno. Bajo ciertas condiciones, las rutas

metabólicas permiten la producción de etanol y acetato, bajando la producción estequiométrica a 2 moles de $\mathrm{H}_{2}$ por mol de glucosa, ecuación 5 (Ghimire et al., 2015).

Para Clostridium articum otra ruta metabólica fermentativa permite la producción de ácido propiónico, que es una ruta consumidora de $\mathrm{H}_{2}$ (ecuación 6). Similarmente algunas rutas metabólicas permiten solo la producción de etanol y ácido láctico sin la producción de $\mathrm{H}_{2}$, como sucede para Clostridium barkeri (ecuación 7 y 8) (Ghimire et al., 2015).

\subsection{Factores que afectan la producción de hidrógeno por fermentación oscura}

El proceso de fermentación oscura en lote está fuertemente influenciada por factores como el tipo de inóculo, la temperatura, el pH, el tipo de sustrato, la acumulación de metabolitos, la carga orgánica (CO) y la presión parcial de hidrógeno (Levin, Pitt, \& Love, 2004). A continuación se discuten algunos de los factores relevantes. 


\subsubsection{Inóculo.}

La mayoría de los estudios emplean cultivos puros para la producción de hidrógeno, sin embargo, el uso de cultivos puros resulta complicado, especialmente si se utilizan residuos complejos como sustratos, ya que es difícil y costoso mantener condiciones asépticas (Mohan et al.,2008).

En general, se considera favorable la utilización de cultivos mixtos de bacterias acidogénicas para la aplicación de la fermentación oscura a gran escala, y estas cepas se encuentran ampliamente distribuidas en ambientes como el suelo, aguas residuales, compostas y en lodos anaerobios utilizados en procesos metanogénicos (Ntaikou et al., 2010). A pesar de las ventajas de los cultivos mixtos en términos de la viabilidad económica del proceso, se corre el riesgo de que predominen las especies consumidoras de hidrógeno, tales como los metanógenos, homoacetógenos y bacterias ácido lácticas (Ntaikou et al., 2010).

Para suprimir la actividad de las bacterias consumidoras de hidrógeno es necesario un tratamiento previo que favorezca, a su vez, la actividad de las bacterias productoras de hidrógeno. Se han utilizado diversos tipos de pre-tratamientos, tales como el térmico, ácido, básico, aereación (RedondasMonteserrín, 2013), además del uso de 2-bromoetanosulfonato de sodio, acetileno, etileno, etano, metil cloruro, metil floruro y lumazina (Valdez-Vazquez \& Poggi-Varaldo, 2009), y del microondas (Faloye et al., 2014). Estos tratamientos consisten en someter a los cultivos mixtos a condiciones de estrés permitiendo seleccionar aquellas bacterias que forman esporas, tales como Clostridium $\mathrm{sp}$. y Bacillus sp. y suprimir a los organismos metanogénicos que no son capaces de esporular (Ntaikou et al., 2010; Redondas-Monteserrín, 2013). Otro método para controlar las arqueas metanogénicas en procesos en lote consisten en reducir el pH del sistema a niveles que son inhibitorios y esto se puede lograr por una simple sobrecarga de sustrato (Valdez-Vazquez \& Poggi-Varaldo, 2009). 


\subsubsection{Sustrato.}

Los carbohidratos son los sustratos más adecuados para la producción fermentativa de hidrógeno, seguidos de las proteínas (Redondas-Monteserrín, 2013). Los carbohidratos modelo, como glucosa, sacarosa y almidón, han sido ampliamente utilizados para la producción de hidrógeno, sin embargo en grado reactivo son caros y esto impide que puedan emplearse para procesos reales a gran escala (Ntaikou et al., 2010), por lo que en la actualidad diversos estudios se han enfocado en la utilización de residuos orgánicos como sustratos aptos para un proceso sostenible. Por lo mismo se han utilizado aguas residuales de diversas industrias de alimentos y, recientemente, residuos de frutas y verduras debido a su alto contenido de carbohidratos (Kapdan \& Kargi, 2006; Mohan et al., 2008; Mohan et al., 2009).

Las concentraciones de sustrato altas pueden mejorar la eficiencia de producción de hidrógeno, pero puede haber inhibición por sustrato o por productos, cuando la relación sustrato/carga orgánica excede de un cierto nivel. No existe una concentración óptima de sustrato para la fermentación, pero la mayoría de los estudios reportan concentraciones de sustrato inferiores a $40 \mathrm{~g} \mathrm{DQO} \mathrm{L-1}^{-1}$ (Lin et al., 2012). 


\subsection{3. $\mathrm{pH}$ del medio.}

El pH es uno de los parámetros clave para la fermentación oscura, el pH pueden afectar directamente la actividad de la hidrogenasa (enzima clave para el proceso) y las rutas metabólicas, y como consecuencia, el rendimiento de producción de hidrógeno así como el tipo de ácidos orgánicos producidos. Durante la producción de hidrógeno por fermentación oscura tiene lugar una disminución gradual del pH, la cual es ocasionada por la producción de ácidos orgánicos; cuando el pH llega a 4.5 se inhibe la producción de hidrógeno (Ghimire et al., 2015; Kumar-Khanal, 2009; RedondasMonteserrín, 2013), por lo que es necesario controlar el pH para mantener los niveles óptimos. El rango de pH reportado para la producción de hidrógeno por fermentación oscura es amplio, varía entre 4.5 y 9. Esto se debe a la diferencia en el origen del inóculo y el método usado para su enriquecimiento, además del tipo de sustrato, la carga orgánica y las condiciones de operación (De Gioannis et al., 2013; Ghimire et al., 2015). A pesar de esto, en la literatura predominan los trabajos que reportan un pH óptimo en el rango de 5-6, en proceso mesofílicos empleando residuos orgánicos (Clark et al., 2012; Lin et al., 2012).

La formación de ácido acético y ácido butírico está influenciada por el pH: cuando el pH del medio se encuentra entre 4 y 6 la cantidad de ácido butírico es mayor que la de ácido acético; mientras que si el pH está entre 6.5 y 7 las cantidades de ácido acético y ácido butírico son semejantes; en cambio, a pH neutro o alcalino se favorece la producción de ácido propiónico y etanol (De Gioannis et al., 2013; Ghimire et al., 2015). A pH cercanos o por debajo de 4.5 hay un cambio de acidogénesis a la producción de solventes, lo que inhibe la producción de $\mathrm{H}_{2}$, por lo que se hace necesario controlar el pH (Clark et al., 2012; De Gioannis et al., 2013).

La alcalinidad inherente de la alimentación contribuye a controlar el pH del reactor, pero no es suficiente y es necesaria la adición de una solución alcalina. De este modo, es importante el estudio 
de métodos para reducir la cantidad externa de alcalinidad para la implementación a gran escala de la tecnología de producción de hidrógeno mediante sistemas de fermentación oscura (RedondasMonteserrín, 2013).

\subsubsection{Presión parcial de hidrógeno $\left(\mathrm{PpH}_{2}\right)$.}

La presión parcial de hidrógeno dentro de un biorreactor afecta la producción de hidrógeno y los productos finales. Una $\mathrm{PpH}_{2}$ baja en el espacio de cabeza de los reactores facilita la transferencia de

masa del hidrógeno de la fase de líquido a gas (Clark et al., 2012; Mandal et al., 2006). Algunos trabajos han demostrado que la reducción de la $\mathrm{PpH}_{2}$ durante la fermentación oscura permite mejorar la producción de hidrógeno (Ghimire et al., 2015; Logan et al., 2002; Mandal et al., 2006). En otros casos, la reducción de la $\mathrm{PpH}_{2}$ no tuvo efecto sobre la producción de hidrógeno (Clark et al., 2012; Kataoka et al., 1997). Sin embargo si la $\mathrm{PpH}_{2}$ incrementa (2.5 atm), la fermentación hidrogenogénica cambia hacia la producción de etanol (Clark et al., 2012). El método más empleado para bajar la $\mathrm{PpH}_{2}$ es el purgado del espacio de cabeza del reactor con nitrógeno o $\mathrm{CO}_{2}$, sin embargo esto hace necesaria la purificación del hidrógeno.

\subsection{PRODUCCIÓN DE HIDRÓGENO POR FERMENTACIÓN LUMINOSA}

La producción de $\mathrm{H}_{2}$ por fotofermentación se considera un proceso sustentable porque utiliza recursos renovables como la luz y la biomasa. Debido a los altos rendimientos de conversión del sustrato a $\mathrm{H}_{2}$ que se pueden lograr, este proceso se considera uno de los más prometedores (Adessi \& De Philippis, 2014). Las BPNS son microorganismos fotoheterótrofos capaces de producir hidrógeno por fotofermentación de AGVs eficientemente bajo condiciones anaerobias, iluminación y limitación de 
nitrógeno, permitiendo la conversión casi estequiométrica de los AGVs a hidrógeno (Abo-Hashesh et al., 2013; Uyar et al., 2007).

Las BPNS descargan el exceso de energía y el poder reductor a través de la producción de hidrógeno bajo limitación de nitrógeno (relación C/N alta) (Akkerman et al., 2002; Koku et al., 2002). Estos microorganismos son capaces de utilizar azúcares, ácidos orgánicos como el succínico, acético, láctico, málico, propiónico y butírico, y compuestos aromáticos para producir $\mathrm{H}_{2}$ (Hay et al., 2013; Lo et al., 2011; McKinlay \& Harwood, 2010; Tao et al., 2008) .

Dentro de las BPNS que se han empleado para la producción de $\mathrm{H}_{2}$ se puede mencionar a Rhodobacter sphaeroides, Rhodobacter capsulatus, Rhodospirullum rubrum y Rhodopseudomonas palustris (Kars \& Gündüz, 2010).

\subsubsection{Características generales de las BPNS}

En el árbol filogenético de la vida, las BPNS gram-negativas son clasificadas como proteobacterias (alfa y beta-proteobacterias). El principal hábitat de las BPNS es el ambiente acuático, como aguas residuales y lagunas. Las BPNS son notables por su versatilidad fisiológica, estos microorganismos son capaces de crecer en anaerobiosis en presencia de luz y condiciones aerobias sin luz, obteniendo energía de la fotosíntesis, respiración o fermentación y producir masa celular a partir de $\mathrm{CO}_{2} \mathrm{O}$ compuestos orgánicos (Laguna, 2010). La producción de hidrógeno sólo ocurre bajo el modo de crecimiento fotoheterótrofo, el cual es también el modo de crecimiento preferido por estos microorganismos, es por eso que las condiciones de operación de los fotobiorreactores se deben ajustar de tal manera que prevalezca el modo fotoheterótrofo, de otra forma, las bacterias pueden cambiar a un metabolismo fermentativo si la disponibilidad de la luz es pobre (Koku et al., 2002).

Las BPNS requieren de vitaminas para su crecimiento, pueden crecer a temperaturas entre 25 y 35 ${ }^{\circ} \mathrm{C}$ y pHs entre 6 y 9 dependiendo de la fuente de carbono. Las células se dividen por fisión binaria, 
producen cápsulas y sustancias viscosas, son móviles por un flagelo polar y de color rojo-púrpura, el cual es debido a los pigmentos como bacterioclorofilas y carotenoides. Otros colores que pueden presentar son amarillo, verde, anaranjado, rojo, vino y café, dependiendo de las condiciones del cultivo, el sustrato, el pH, y la edad del cultivo, entre otros; por ejemplo los cultivos viejos son de color café, que van de un tono verdoso a marrón oscuro (Madigan et al., 2004; Uyar, 2010).

\subsubsection{Sistema de producción de hidrógeno por las BPNS}

Tres componentes fisiológicos individuales constituyen el sistema de producción de hidrógeno en las BPNS: (i) el sistema enzimático, (ii) el ciclo de los ácidos tricarboxílicos (TCA) (flujo de carbono), y (iii) el aparato fotosintético. Estos sistemas intercambian electrones, protones y ATP (Gest et al., 1962; Koku et al., 2002).

Las BPNS tienen la capacidad de absorber energía luminosa y almacenarla como energía química vía la formación de enlaces químicos mediante un fotosistema que consiste de pigmentos que absorben la luz y un "centro de reacción" que consiste en una molécula fuertemente especializada compuesta por bacterioclorofila a (P680) que transforma energía luminosa (fotones) en energía química (ATP). Este fotosistema (PS II) es sencillo (Akkerman et al., 2002) y por sí mismo no puede romper el agua y extraer los protones y electrones como sucede en las algas (que contienen 2 fotosistemas) (Melis \& Melnicki, 2006). Sin embargo, bajo condiciones anaerobias, estas bacterias son capaces de utilizar ácidos orgánicos simples o disulfuro de hidrógeno como donadores de electrones (Akkerman et al., 2002) y en comparación con la disociación del agua llevada a cabo por las algas, las BPNS requieren mucho menos energía para disociar los AGVs y producir hidrógeno (+8.5 kJ mol-1 $\mathrm{H}_{2}$ para lactato) (Basak et al., 2014).

En la Figura 5 se presenta un esquema general de la producción de hidrógeno por las BPNS. El proceso comienza con la liberación de electrones a partir de los AGVs por medio del ciclo de los TCA 
y los producidos por la NADH deshidrogensa (NADH-DH) que se bombean a través de un gran número de transportadores de electrones (entre los cuales están: Q (quinona), y los citocromos Cyt bc 1 y Cyt $\mathrm{C}_{2}$ ). Durante el transporte de electrones, los protones se bombean a través de la membrana (esto es en el complejo proteínico citocromo $b_{1}$ ). Se desarrolla un gradiente de protones: alta $\left[\mathrm{H}^{+}\right]$en el periplasma y baja $\left[\mathrm{H}^{+}\right]$en el citoplasma, que es usado por la enzima ATP sintasa para generar ATP (Akkerman et al., 2002).

La transferencia de los electrones del TCA hacia la nitrogenasa se lleva a cabo por la oxidaciónreducción consecutiva de los acarreadores de electrones, NAD+ y ferrodoxina (Fd) (Hay et al., 2013). La enzima Mo-nitrogenasa puede usar esos electrones para reducir el nitrógeno molecular y convertirlo en amonio (utilizando "energía ATP" extra) (Akkerman et al., 2002) con la producción simultánea de $\mathrm{H}_{2}$, de acuerdo con la ecuación 9 (Tabla 2) (Melis \& Melnicki, 2006). Sin embargo, la producción de $\mathrm{H}_{2}$ en el contexto de la fijación de nitrógeno es un proceso ineficiente debido a que cerca del $75 \%$ del poder reductor consumido por la Mo-nitrogenasa se usa para generar amonio (Rey et al., 2007).

Cuando el nitrógeno molecular no está presente esta enzima puede reducir los protones y electrones derivados a partir de la ferredoxina en gas hidrógeno $\left(\mathrm{H}_{2}\right)$ utilizando energía extra (Akkerman et al., 2002). De forma que para producir $\mathrm{H}_{2}$ se requiere 4 ATP y 2 electrones (ecuación 10, Tabla 2) (McKinlay \& Harwood, 2010). 


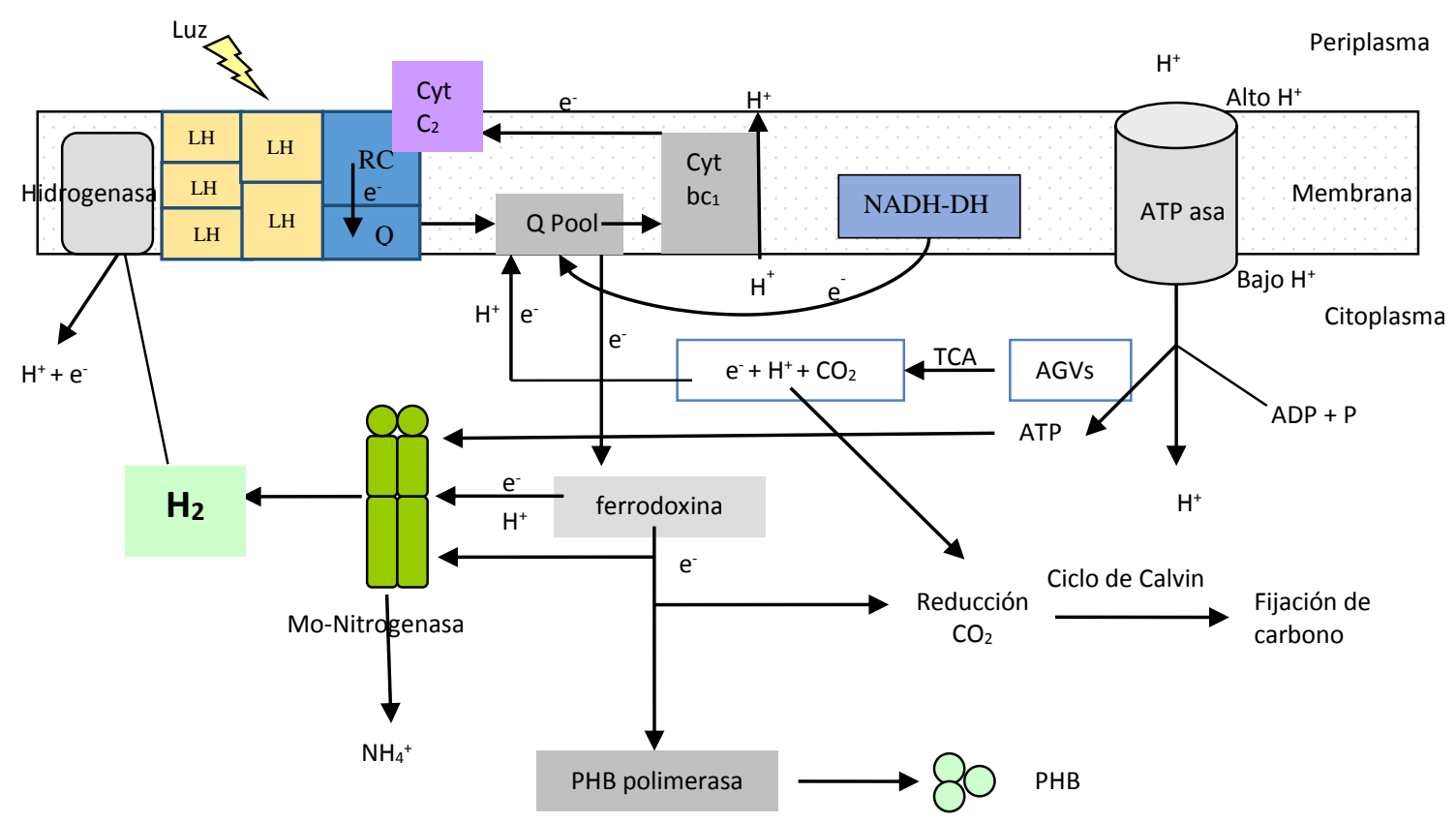

Figura 5. Fotosistema y rutas metabólicas involucradas en la producción de $\mathrm{H}_{2}$ por las BPNS. La producción total de $\mathrm{H}_{2}$ va acompañada por varios eventos metabólicos como es la producción de poli-3-hidroxibutirato (PHB) y el consumo de hidrógeno por la hidrogenasa. Adaptado de Adessi \& De Philippis, 2014; Akkerman et al., 2002; Kars \& Gündüz, 2010; Kars et al., 2008.

La ruta metabólica general para el proceso de fotofermentación en forma simplificada puede esquematizarse de la siguiente manera (Hay et al., 2013):

$$
\text { Sustrato } \rightarrow \text { ciclo de TCA } \rightarrow \text { NAD/NADH } \rightarrow \text { Ferredoxina } \rightarrow \text { Nitrogenasa } \rightarrow \mathrm{H}_{2}
$$

Durante la fase exponencial del crecimiento de las BPNS, el carbono orgánico se utiliza para: la generación de $\mathrm{NADH}$, la síntesis de precursores biosintéticos y, una mínima porción, para la 
producción de hidrógeno. En esta fase el ciclo de Calvin consume la mayor parte de los electrones en exceso a través de la reducción de dióxido de carbono en intermediarios biosintéticos.

En la fase estacionaria, cuando la biosíntesis es mínima, la mayoría del carbono orgánico se oxida en dióxido de carbono y la mayoría de los electrones extraídos se dirigen a la producción de hidrógeno para disipar el exceso de electrones. Los aceptores de electrones alternativos, como la nitrogenasa, toman importancia, lo que se correlaciona con una mayor producción de hidrógeno durante esta fase de crecimiento.

Otras formas de disipar el exceso de electrones y mantener el equilibrio redox adecuado implican la síntesis de PHB (ver Figura 5) (Gabrielyan et al., 2014; Golomysova et al., 2010).

\subsubsection{Nitrogenasas}

La reducción del nitrógeno molecular a amoniaco se lleva a cabo por el sistema enzimático nitrogenasa de dos componentes. El primer componente es una metaloproteína de hierro que se designa como Fe-proteína, proteína de hierro, componente 1, o bien $\mathrm{NifH}$. El segundo componente es una metaloproteína que alberga a uno de tres posibles co-factores - un clúster (cúmulo) de Mo-Fe, un clúster de V-Fe, o un clúster únicamente de $\mathrm{Fe}-$; en el caso del co-factor de Mo-Fe, se le conoce como Mo-Fe-proteína o componente 2, y es la más común (Bertini et al., 2001).

Todas las Fe-proteínas de bacterias fijadoras de nitrógeno (incluyendo eubacterias, archaebacterias, y cianobacterias) son homodímeros de 60 a $70 \mathrm{kDa}$ que tienen una coincidencia en sus secuencias igual o mayor del 45\%, y que contienen un co-factor consistente en un clúster de $\mathrm{Fe}_{4} \mathrm{~S}_{4}$, el cual es sensible al oxígeno (Bertini et al., 2001).

La Mo-Fe-proteína es un tetrámero de un peso molecular de aproximadamente 240 kDa que se identifica como $\alpha_{2} \beta_{2}$-tetrámero. Las sub-unidades $\alpha$ y $\beta$ se encuentran relacionadas por un pseudo 
eje de simetría de orden 2 y cada mitad $\alpha-\beta$ de la proteína posee un clúster de azufre-Fe-Mo conocido como FeMo y un clúster 8Fe-7S conocido como P-clúster (Bertini et al., 2001).

Diversos estudios indican que todos los diazótrofos tienen Mo-nitrogenasa, que es codificada por genes nifHDK. A partir de la secuencia de los genomas se sabe que $R$. sphaeroides sólo tiene Monitrogenasa; $R$. capsulatus y $R$. rubrum tienen una nitrogenasa alternativa adicional, la Fe-nitrogenasa codificada por genes anfHDGK; $R$. palustris CGA009, tiene genes para tres nitrogenasas diferentes, por lo tanto parece ser un buen catalizador para la producción de hidrógeno (Kars \& Gündüz, 2010). En la Tabla 2 se muestran las reacciones catalizadas por los tres tipos de nitrogenasas presentes en las BPNS (McKinlay \& Harwood, 2010). 

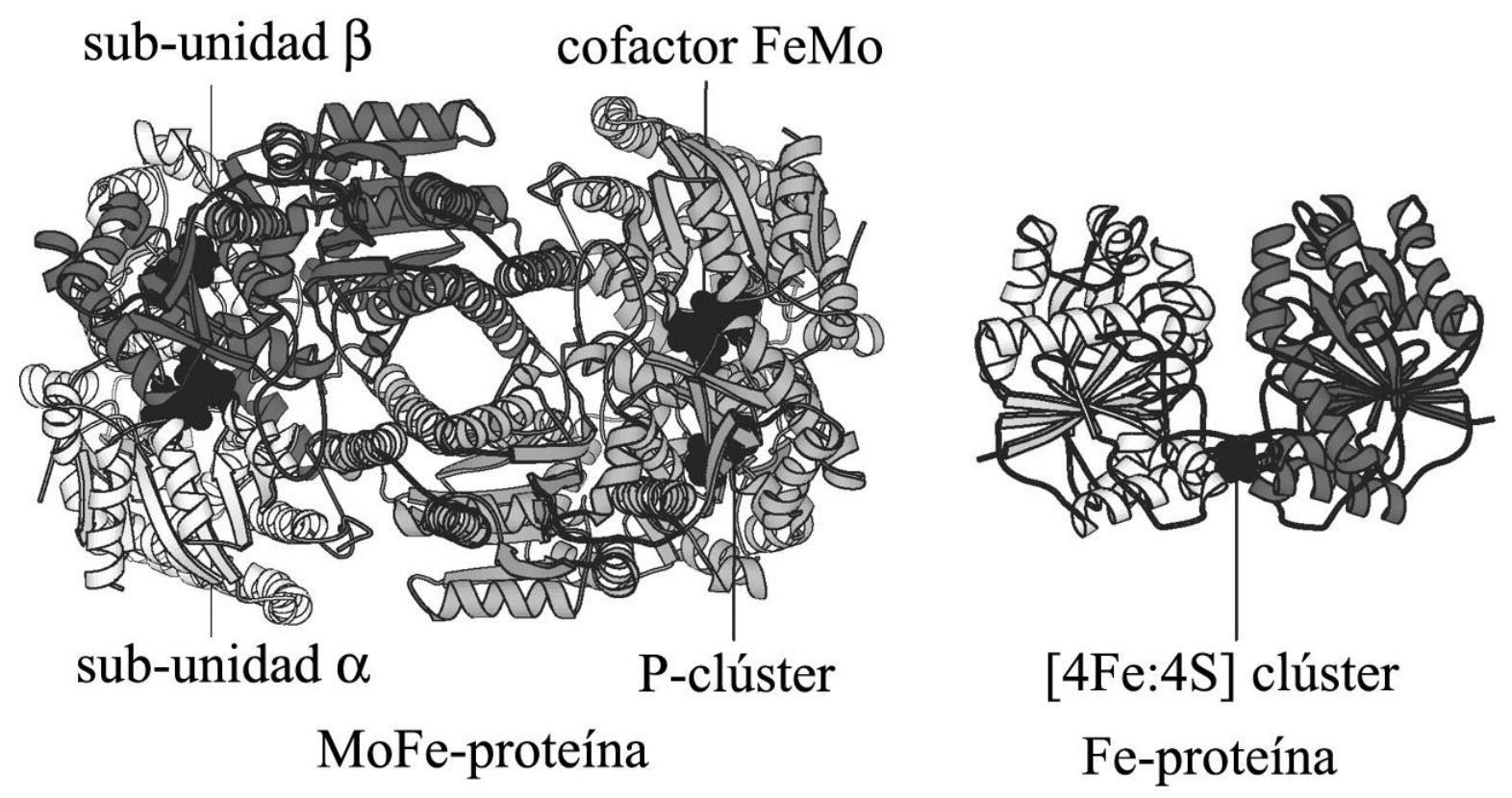

\section{Fe-proteína}
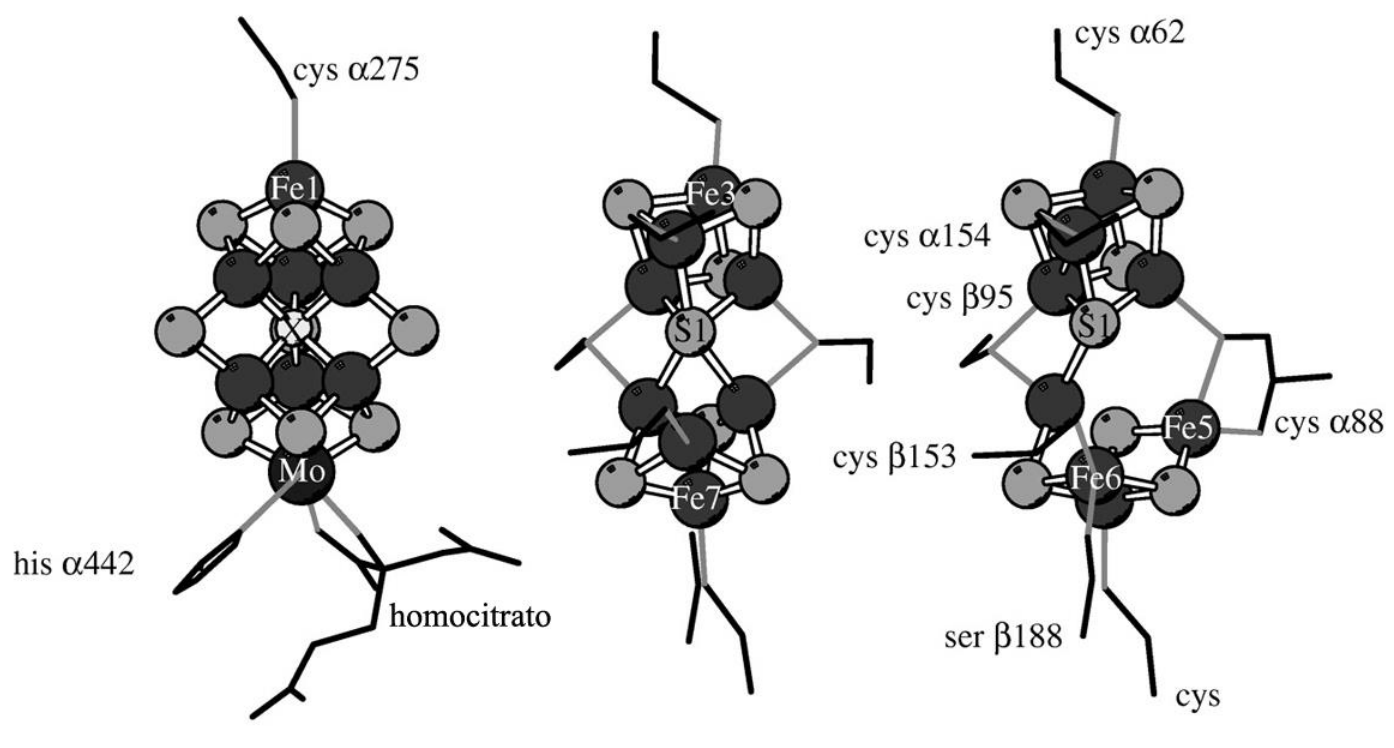

cofactor FeMo

$$
\mathrm{P}^{\mathrm{N}} \text {-clúster }
$$

$\mathrm{P}^{\mathrm{OX}}$-clúster

Figura 6. Arriba: Diagrama de cintas de la nitrogenasa con su componente 1: Fe-proteína (derecha), y componente 2: MoFe-proteína (izquierda). Las subunidades a y $\beta$ a la izquierda de la MoFe-proteína están representadas con diferente sombreado, mientras que los clúster metálicos están representados por los modelos de esferas oscuras; Abajo: Estructuras de los clúster metálicos cofactores de la MoFe-proteína representados en modelos de esferas sombreadas de acuerdo al tipo de átomos. Modificado de Rees et al., 2005). 
Tabla 2. Reacciones catalizadas por los tres tipos de nitrogenasas presentes en las BPNS.

\begin{tabular}{lcc}
\hline \multicolumn{1}{c}{ Reacción } & Tipo de nitrogenasa & Ec. \\
\hline $\mathrm{N}_{2}+8 \mathrm{e}^{-}+8 \mathrm{H}^{+}+16 \mathrm{ATP}+16 \mathrm{H}_{2} \mathrm{O} \rightarrow 2 \mathrm{NH}_{3}+\mathrm{H}_{2}+16 \mathrm{ADP}+16 \mathrm{Pi}$ & Mo-nitrogenasa en & 9 \\
& presencia de $\mathrm{N}_{2}$ & \\
$2 \mathrm{H}^{+}+2 \mathrm{e}^{-}+4 \mathrm{ATP} \rightarrow \mathrm{H}_{2}+\mathrm{ADP}+4 \mathrm{Pi}$ & Mo-nitrogenasa bajo & 10 \\
$\mathrm{~N}_{2}+12 \mathrm{H}^{+}+12 \mathrm{e}^{-}+24 \mathrm{ATP} \rightarrow 2 \mathrm{NH}_{3}+3 \mathrm{H}_{2}+24 \mathrm{ADP}$ & limitación de $\mathrm{N}_{2}$ \\
$\mathrm{~N}_{2}+24 \mathrm{H}^{+}+24 \mathrm{e}^{-}+48 \mathrm{ATP} \rightarrow 2 \mathrm{NH}_{3}+9 \mathrm{H}_{2}+48 \mathrm{ADP}$ & V-nitrogenasa & 11 \\
\hline
\end{tabular}

El funcionamiento eficiente de la nitrogenasa requiere grandes cantidades de ATP y poder reductor, por lo que su síntesis y actividad está sujeta a controles regulatorios estrictos por la presencia del ión amonio (Adessi \& De Philippis, 2014; Koku et al., 2002). El ión amonio inhibe la síntesis y la actividad de la nitrogenasa a concentraciones tan bajas como $0.1 \mathrm{mM}$ en $R$. sphaeroides (Hillmer \& Gest, 1977). Esta inhibición es reversible, una vez que el ión amonio se ha consumido la nitrogenasa recobra su actividad. Para evitar dicha inhibición se deben buscar relaciones $\mathrm{C} / \mathrm{N}$ altas en los medios de cultivo (Koku et al., 2002). Por otro lado, algunos investigadores han realizado modificaciones genéticas para interrumpir los genes que codifican proteínas que tienen un papel crucial en la represión de la expresión de la nitrogenasa en la presencia del ión amonio (Kim et al., 2008).

La síntesis de nitrogenasa se estimula fuertemente por la luz, resultando en un incremento en la actividad nitrogenasa como lo observaron Jouanneau et al. (1985) en cultivos continuos de $R$. capsulatus. Sin embargo, a altas intensidades luminosas la eficiencia de conversión de la energía luminosa a hidrógeno decrece (Wakayama \& Miyake, 2002). Vale la pena señalar que un patrón de iluminación diurna (aquella que involucra períodos alternados de luz y oscuridad) puede resultar en una actividad nitrogenasa más estable (Miyake et al., 1999). 
La nitrogenasa, al igual que el aparato fotosintético, es sensible al oxígeno del aire (Vignais et al., 1985). Por lo tanto, la mayoría de los investigadores usan argón para mantener condiciones anaerobias (Liu et al., 2009).

\subsubsection{Hidrogenasa}

Se han identificado tres clases de hidrogenasas hasta el momento: [Fe]-hidrogenasa, [NiFe]hidrogenasa y [NiFeSe]-hidrogenasa. Estas enzimas catalizan la reacción redox: $\mathrm{H}_{2} \rightarrow 2 \mathrm{H}^{+}+2 \mathrm{e}^{-}$ (Basak et al., 2014).

La [NiFe] hidrogenasa se encuentra en las BPNS y cianobacterias (Eroglu \& Melis, 2011). Por lo general la [NiFe]-hidrogenasa es responsable del consumo de hidrógeno (Basak et al., 2014), por lo que su actividad consumidora de hidrógeno va en detrimento de la producción de hidrógeno por fotofermentación. Los principales inhibidores de estas enzimas son el $\mathrm{CO}$ y el $\mathrm{O}_{2}$, aunque resiste concentraciones más altas de $\mathrm{O}_{2}$ que la nitrogenasa. Otros inhibidores son el ácido etilendiamintetraacético (EDTA), la limitación de níquel en el medio que puede disminuir la síntesis de la enzima y, en algunas especies, la síntesis de la enzima también se ve afectada por altas concentraciones de compuestos orgánicos (Koku et al., 2002).

Dentro de las estrategias para disminuir el consumo del hidrógeno por parte de la [NiFe]-hidrogenasa, está la remoción del hidrógeno producido en el medio manteniendo una baja la presión parcial de hidrógeno ( $\mathrm{PpH}_{2}$ ), o utilizar microorganismos modificados genéticamente (Basak et al., 2014). Algunos investigadores han eliminado la capacidad de sintetizar esta enzima en las células, por ejemplo Kars et al. (2008) introdujeron un vector suicida en el gen hupSL de Rhodobacter sphaeroides O.U.001 para apagar el gen de la hidrogenasa, con lo que lograron mejorar en un 20\% la producción de hidrógeno. 


\subsubsection{Aparato fotosintético}

La energía requerida para el crecimiento, así como para la actividad productora de hidrógeno por la nitrogenasa se obtiene a través del aparato fotosintético, el cual convierte la energía luminosa en energía química (ATP). El aparato fotosintético se encuentra en la membrana celular y está constituido por un complejo ATPasa que permite la síntesis de ATP a expensas de un gradiente de protones, así como vesículas recolectoras de luz (LH1 y LH2), pigmentos fotosintéticos (bacterioclorofilas, carotenoides, espiroloxantina, etc), el centro de reacción (RC) y una cadena transportadora de electrones (Basak et al., 2014; Koku et al., 2002). Los complejos LH recolectan la energía luminosa y la canalizan al RC, de donde inicia un flujo cíclico de electrones que implica varios acarreadores de electrones, lo que resulta en la generación de un gradiente de protones (ver Figura 5) (Koku et al., 2002).

La energía luminosa absorbida por los pigmentos que funcionan como antenas se transfiere a los dímeros de bacterioclorofila que constituyen electrodonadores primarios. Estos dímeros están enlazados a las proteínas de los centros de reacción (RCs). Los RCs de las BPNS son del tipo II, en el cual los pigmentos son dímeros de bacterioclorofila II a (P870). Los RCs usan moléculas especializadas para transformar la energía luminosa en química: los citocromos solubles o enlazados a la membrana que actúan como donadores inmediatos de electrones al RC; la bactereofitina a y la ubiquinona, que actúan como aceptores de electrones externos (ver Figura 5) (Basak et al., 2014). El oxígeno es el principal regulador de la síntesis del aparato fotosintético, su presencia reprime de inmediato la síntesis de moléculas de bacterioclorofila siendo un efecto reversible pues la síntesis se reanuda una vez que el oxígeno se elimina. La luz también controla la síntesis, pero su efecto no es tan severo como el oxígeno. Bajo una atmósfera anaerobia, el número de vesículas fotosintéticas producidas varía inversamente con la intensidad de la luz incidente. La síntesis incluso no se detiene 
en la oscuridad, aunque el cultivo repetido sucesivamente en esta forma resulta en el cese total de la síntesis de bacterioclorofila (Koku et al., 2002).

\subsubsection{Asimilación de las fuentes de carbono}

Las BPNS son capaces de utilizar una gran variedad de sustratos como fuentes de carbono y nitrógeno, por lo que las rutas metabólicas utilizadas son diversas y pueden diferir entre las especies o entre diferentes cepas de la misma especie. Sin embargo, se puede establecer un esquema general simplificado del flujo de carbono en las BPNS, que se muestra en la Figura 7 (Koku et al., 2002).

Algunas características interesantes de la utilización de las fuentes de carbono se pueden observar en esta figura, por ejemplo se ha observado que mientras el malato y lactato son eficientemente convertidos a hidrógeno, el acetato y la glucosa no son tan eficientes en este aspecto. El lactato y malato pueden entrar fácilmente en el ciclo de los TCA (ciclo de Krebs) (Figura 7) y satisfacer la necesidad de energía de la célula para la producción de hidrógeno. Sin embargo, sustratos como el acetato necesitan utilizar vías laterales donde se sintetizan ácidos de cuatro carbonos como malato y succinato para entrar al ciclo de los TCA a nivel de la acetil-CoA (Kars \& Gündüz, 2010). La R. sphaeroides usa la ruta del etilmalonil-CoA para asimilar el acetato, la $R$. capsulatus utiliza la ruta del citramalato y la R. palustris utiliza la del glioxalato (Kars \& Gündüz, 2010).

Se sabe que las BPNS necesitan un aceptor de electrones cuando el sustrato tiene un estado de oxidación más reducido que los componentes celulares como el ácido propiónico o butírico (Ormerod, 1956; Takabatake et al., 2004). 


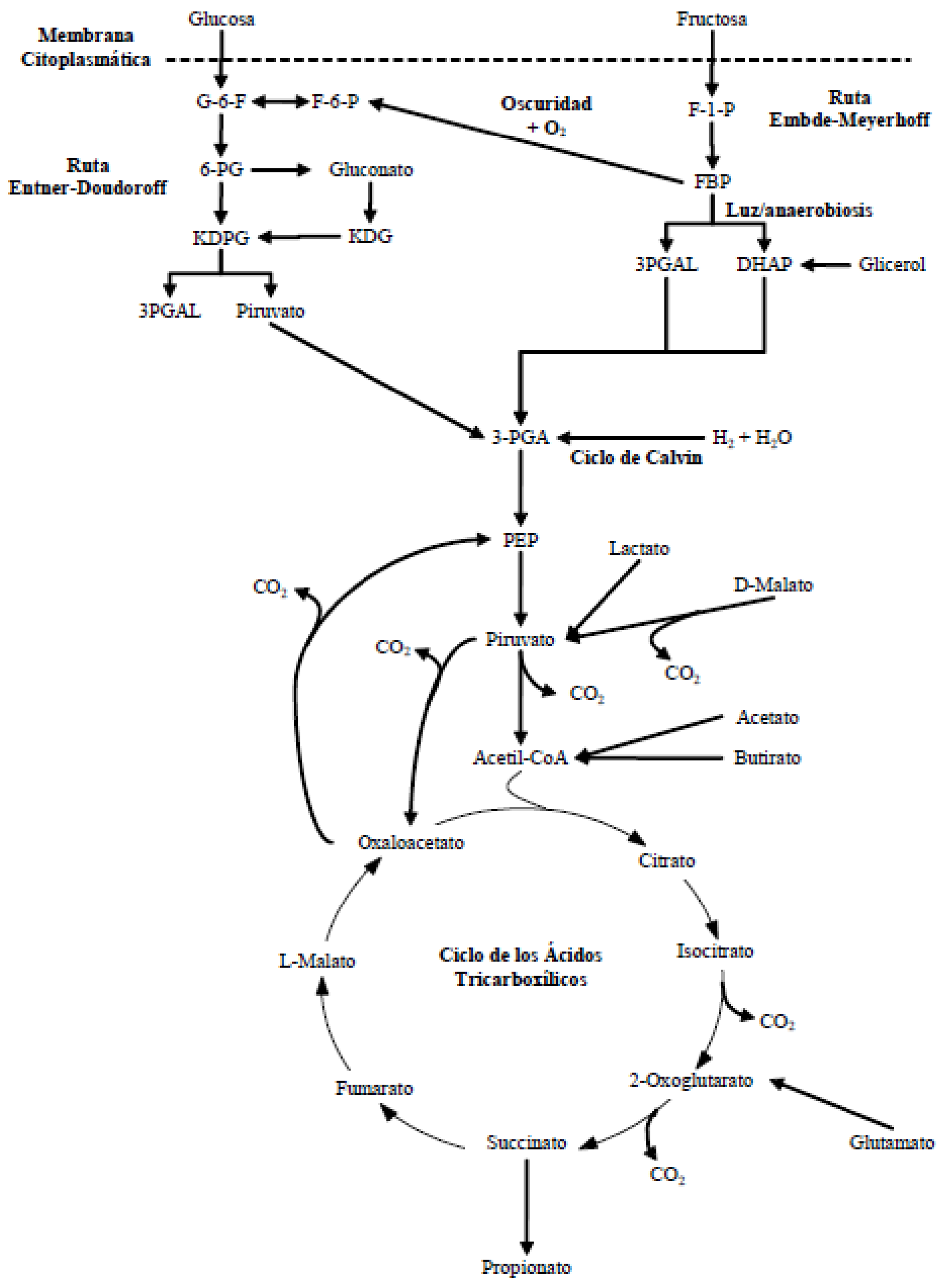

Figura 7. Esquema general del metabolismo de carbono en las BPNS. (Figura tomada de Koku et al., 2002). 


\subsubsection{Producción de PHB}

Como se mencionó antes, el flujo de protones, electrones y $\mathrm{CO}_{2}$, extraídos por el ciclo TCA también pueden destinarse a la síntesis de PHB (Golomysova et al., 2010), que constituye uno de los productos alternativos al hidrógeno. Este material es particularmente crítico debido a que su papel fisiológico es similar al de la producción de hidrógeno (Koku et al., 2002) y las BPNS pueden acumular PHB como material de reserva cuando se encuentran en condiciones ambientales subóptimas. La cantidad de PHB que pueden acumular parece estar relacionado con la naturaleza del sustrato, la especie, las rutas metabólicas empleadas para asimilar los sustratos, el pH y el régimen de iluminación ( Fradinho et al., 2013; Hustede et al., 1993; Kars \& Gündüz, 2010; Kranz et al., 1997;Sharma \& Mallick, 2005). 


\section{PLANTEAMIENTO}

La gran mayoría de los procesos de foto-fermentación para la producción de hidrógeno que se han llevado a cabo hasta ahora han sido en lote, con fuentes de carbono puras y estériles, usando cultivos puros y bajo condiciones controladas de laboratorio con iluminación artificial continua y desgasificación con argón para mantener condiciones anaerobias y mantener una presión parcial de hidrógeno baja. Estas condiciones junto a la pequeña escala a la cual estas tecnologías se han probado, además del alto consumo de energía por las fuentes de luz artificiales encarecen el proceso y son difíciles de implementar cuando se desea escalar el proceso. Para que, en la práctica, la producción biológica de $\mathrm{H}_{2}$ a gran escala sea rentable y sustentable se requiere mejorar las eficiencias de producción de $\mathrm{H}_{2}$ mediante estrategias que permitan reducir los costos de operación y para ello algunas de las alternativas a evaluar son: el uso de DFE no estériles provenientes de la fermentación de residuos orgánicos, cultivos de BPNS obtenidos de fuentes económicas como lo son los cuerpos de aguas residuales, fotobiorreactores que operen con bajo consumo de energía, con luz solar al aire libre 0 bajo iluminación intermitente, además de escalar los procesos, prescindir del uso de Ar y aprovechar los subproducto del proceso como el PHB que es polímero de interés comercial. 


\section{HIPÓTESIS}

El uso de presión reducida, $\mathrm{CO}_{2}$, consorcios de $\mathrm{BPNS}, \mathrm{NaHCO}_{3}$, condiciones de incubación ambientales y bajo ciclos luz-oscuridad, así como agitación intermitente permitirán tener producciones de hidrógeno similares a los procesos que emplean cepas puras, argón, incubación controlada, iluminación continua y agitación constante.

\section{OBJETIVO GENERAL}

Estudiar el efecto de métodos de desgasificación alternos al uso de Ar, patrón de iluminación, régimen de limentación y frecuencia de agitación sobre la producción de $\mathrm{H}_{2}$ vía foto-fermentación por un consorcio de BPNS y por $R$. capsulatus utilizando como sustrato efluentes de fermentación oscura. 


\section{OBJETIVOS ESPECÍFICOS}

1. Obtener un cultivo mixto de BPNS productor de $\mathrm{H}_{2}$ de una fuente de aguas residuales.

2. Obtener efluentes ricos en AGVs por fermentación oscura de residuos vegetales.

3. Evaluar el efecto del purgado con $\mathrm{CO}_{2}$ y presión reducida sobre la producción de $\mathrm{H}_{2}$.

4. Estudiar el efecto de la adición de $\mathrm{Na}_{2} \mathrm{HCO}_{3}$ a los efluentes de fermentación oscura.

5. Comparar la eficiencia de producción de $\mathrm{H}_{2}$ bajo iluminación continua en condiciones de laboratorio y con ciclos de luz/oscuridad en condiciones ambientales

6. Operar reactores en lote secuencial bajo ciclos luz-oscuridad para la producción de $\mathrm{H}_{2}$.

7. Producir hidrógeno en un fotobiorreactor de más de $10 \mathrm{~L}$.

8. Determinar la acumulación de PHB en el cultivo mixto de BPNS y R. capsulatus.

9. Caracterizar por técnicas de biología molecular el cultivo mixto de BPNS aislado. 


\section{ESTRATEGIA EXPERIMENTAL GENERAL.}

En la tabla 3 se presenta de manera general la estrategia de trabajo que se siguió para cumplir con los objetivos planteados.

Tabla 3. Estrategia experimental

\begin{tabular}{|c|c|}
\hline \multicolumn{2}{|c|}{ ETAPA I. Obtención de cultivos de BPNS y efluentes de fermentación oscura } \\
\hline $\begin{array}{c}\text { Actividad 1.1. Obtención de efluentes ricos en AGVs por } \\
\text { fermentación hidrogenogénica de residuos vegetales y } \\
\text { caracterización. }\end{array}$ & $\begin{array}{c}\text { Actividad 1.2. Obtención, selección y enriquecimiento de } \\
\text { cultivos mixtos fotoheterótrofos de BPNS. }\end{array}$ \\
\hline ETAPA II. Ensayos de producción de $\mathrm{H}_{2}$ en lote para selección de condiciones de operación. \\
\hline $\begin{array}{c}\text { Actividad 2.1. Selección del mejor cultivo } \\
\text { productor de H2, concentración de extractos } \\
\text { acidogénicos y pH inicial }\end{array}$ & $\begin{array}{c}\text { Actividad 2.3. Evaluación del método para propiciar condiciones } \\
\text { anaerobias (vacío, purgado con argón o CO } \text { CO }_{2} \text {, selección de la } \\
\text { cantidad adecuada de NaHCO } 3 \text { y ensayos bajo condiciones de } \\
\text { laboratorio y ambientales }\end{array}$ \\
\hline ETAPA III. Producción de hidrógeno bajo periodos luz-oscuridad \\
\hline Actividad 3. Ensayos de producción de bajo ciclos luz-oscuridad artificiales. \\
\hline ETAPA IV. Ensayos de producción de hidrógeno en lote secuencial \\
\hline Actividad 4. Producción de hidrógeno en lote secuencial bajo ciclos luz-oscuridad
\end{tabular}

El diseño de experimentos y metodologías que se llevaron a cabo para realizar cada una de las actividades de la estrategia experimental se describen a detalle en los siguientes capítulos. 


\section{RESULTADOS}




\section{CAPÍTULO 2}

\section{PRODUCCIÓN DE HIDRÓGENO POR UN CULTIVO FOTOHETERÓTROFO USANDO UN EFLUENTE DE FERMENTACIÓN OSCURA COMO SUSTRATO: EFECTO DEL MÉTODO DE PURGADO, ADICIÓN DE BICARBONATO, E INCUBACIÓN BAJO CONDICIONES CONTROLADAS Y}

Los resultados de este capítulo fueron publicados en la revista "International Journal of Hydrogen Energy" (Ver apéndice 2) y a continuación se presenta la traducción del artículo.

\subsection{Introducción}

La producción de hidrógeno por vía fermentativa a partir de residuos orgánicos es una alternativa para obtener energía renovable y darle tratamiento a los residuos orgánicos de una forma ambientalmente amigable. Dentro de los métodos biológicos más prometedores para la producción de hidrógeno y más cercanos a la comercialización están la fermentación oscura donde actúan bacterias fermentativas y la foto-fermentación donde las bacterias púrpuras no del azufre (BPNS) llevan a cabo el proceso (Singh et al., 2015). La fermentación oscura tiene tasas de producción de hidrógeno más altas y requerimientos operacionales más bajos que la foto-fermentación (Chang \& Hsu, 2012), pero bajos rendimientos debido a la incompleta degradación de los residuos y a la acumulación de ácidos, 
limitando los rendimientos a menos del $20 \%$ del valor teórico de $12 \mathrm{~mol} \mathrm{H}_{2} \mathrm{~mol}^{-1}$ glucosa. Los ácidos grasos volátiles (AGVs) acumulados durante la fermentación oscura pueden ser posteriormente convertidos a hidrógeno con altas eficiencias estequiométricas, hasta rendimientos de $8 \mathrm{~mol} \mathrm{H}_{2} \mathrm{~mol}^{-1}$ glucosa pueden ser obtenidos con un proceso en dos etapas involucrando la fermentación oscura y la foto-fermentación (Kim \& Kim, 2013).

Para la producción de hidrógeno por foto-fermentación los investigadores generalmente usan cultivos puros de BPNS bajo condiciones estériles (Cai et al., 2012) con sustratos modelo como succinato, lactato, butirato, malato, acetato y propiónato (Cai et al., 2012; Tao et al., 2008; Li et al., 2011), pero recientemente sustratos más complejos como efluentes de fermentación oscura (DFE) de residuos del cultivo de maíz, cascaras de papa hidrolizadas, suero de queso, melaza, hidrolizado de paja de cebada entre otros (Afsar et al., 2011; Azbar et al., 2010; Özgür et al., 2010; Özgür \& Peksel, 2013; Yang et al., 2010; ) han sido empleados. Cultivos enriquecidos de BPNS obtenidos de aguas residuales podrían ser interesantes para la producción de hidrógeno debido a que pueden ser metabólicamente más versátiles y eficaces en el uso de sustratos complejos en comparación con los cultivos puros (Cai et al., 2012), sin embargo, cultivos fotoheterótrofos enriquecidos de BPNS con sustratos complejos no han sido ampliamente utilizados.

La producción de hidrógeno por BPNS está asociada con la nitrogenasa que promueve la conversión de $\mathrm{N}_{2}$ y protones a amonio e hidrógeno. Sin embargo, la nitrogenasa es inhibida por oxígeno (Koku et al., 2002; Liu et al., 2009) y por lo tanto es necesario mantener condiciones anaerobias. También es necesario mantener una presión parcial de hidrógeno baja en el headspace debido a que las hidrogenasas (como la NiFe-hidrogenasa) pueden re-oxidar el hidrógeno producido en protones y electrones (Koku et al., 2002). El argón es frecuentemente empleado para purgar el oxígeno y nitrógeno del headspace de los reactores y para mantener la presión parcial de hidrógeno baja, pero esto incrementa los costos de producción y dificulta la purificación del hidrógeno. Algunos trabajos han 
alternativamente empleado presión reducida y $\mathrm{CO}_{2}$ para purgar el headspace y mantener una presión parcial de hidrógeno baja en fermentación oscura (Clark et al., 2012; Kim et al., 2012), pero en fotofermentación la información al respecto es escasa.

La producción de hidrógeno en condiciones ambientales es afectada por la intensidad luminosa solar y los cambios de temperatura. Esas variables no controlables regulan la actividad fotosintética y junto con los ciclos luz-oscuridad diarios, las variaciones estacionales y geográficas pueden influir en gran medida en el crecimiento y la producción de hidrógeno. Por lo tanto, es importante evaluar el efecto de tales condiciones sobre el potencial de los cultivos productores de hidrógeno.

También se sabe que las BPNS necesitan de un aceptor de electrones cuando el sustrato es más reducido que los componentes celulares. Se ha demostrado que la presencia de ion carbonato en medios de crecimiento para las BPNS mejora el consumo de AGVs, ya que el carbonato sirve como un aceptor de electrones en exceso cuando se emplean como sustrato ácido propiónico y butírico que son más reducidos que los componentes celulares (Ormerod, 1956; Takabatake et al., 2004). A pesar de esta evidencia y de que el ácido butírico es uno de los mayores sub-productos de la fermentación oscura, el carbonato no ha sido usado para mejorar la producción de hidrógeno por fotofermentación de DFE ricos en ácido butírico o propiónico.

Las BPNS pueden acumular (PHB) como material de reserva energética cuando se encuentran en condiciones sub-óptimas. La cantidad de PHB que pueden acumular depende de la especie de BPNS, del sustrato y de sus rutas metabólicas. Por ejemplo, Rhodobacter sphaeroides emplea la ruta del Etilmalonil-CoA para asimilar acetato. Esta ruta tiene elementos comunes con la empleada para la síntesis de PHB permitiéndole a $R$. sphaeroides acumular altos niveles de PHB $(80 \%$ de su peso celular seco) (Kars \& Gündüz, 2010). La ruta de asimilación en Rhodobacter capsulatus es a través del ciclo del citramalato (Kranz et al., 1997). En Rhodopseudomonas palustris, el acetato es asimilado a través del ciclo del Glioxalato, Wu et al. (2012) reportaron que la cepa WP3-5 no puede utilizar malato 
y lactato para producir PHB, solo lo sintetiza con acetato y propionato acumulando 10\% en peso. La acumulación de PHB en las BPNS puede competir con la producción de hidrógeno por los electrones y distribución de energía, así que es importante determinar la acumulación de PHB para evaluar la perdida de producción de hidrógeno (Wu et al., 2012). Como el PHB es un polímero biodegradable (Kranz et al., 1997), también puede ser recuperado como un subproducto del proceso de producción de hidrógeno.

En este trabajo se explora la producción de hidrógeno por un cultivo foto-heterótrofo enriquecido de BPNS y R. capsulatus bajo condiciones no estériles usando un efluente de fermentación oscura real como sustrato. Argón, presión reducida y $\mathrm{CO}_{2}$ fueron probados para mantener condiciones anaerobias y bajar la presión parcial de hidrógeno. El uso de bicarbonato también fue explorado para mejorar la producción de hidrógeno. Los experimentos fueron realizados bajo condiciones controladas con iluminación continua y en condiciones ambientales con ciclos luz-oscuridad naturales. La remoción de DQO y acumulación de PHB fueron también medidos para estimar beneficios potenciales como la producción de un compuesto de valor agregado y el tratamiento de residuos.

\subsection{Material y métodos.}

\subsubsection{Inóculo}

El cultivo fotoheterótrofo enriquecido fue obtenido mediante el uso de una columna de Winogradsky preparada con lodos activados colectados de la planta de tratamiento de aguas residuales "Cerro de la Estrella" localizada en San Juan Xalpa, Iztapalapa en la Ciudad de México D.F.

La columna Winogradsky se preparó con $800 \mathrm{~mL}$ de lodos activados, $12.5 \mathrm{~g}$ de $\mathrm{CaSO}_{4}, 12.5 \mathrm{~g}$ de $\mathrm{CaCO}_{3}$ y $25 \mathrm{~g}$ de aserrín. Los ingredientes fueron colocados en una columna de vidrio de $1 \mathrm{~L}$ de capacidad. La columna fue colocada cerca de una ventana a temperatura ambiente $\left(25-28^{\circ} \mathrm{C}\right)$ por 15 
días; después de este periodo, una muestra de $5 \mathrm{~mL}$ de la banda rojiza bajo la superficie del líquido de la columna fue colectada y transferida a botellas serológicas con $85 \mathrm{~mL}$ de medio Pfennig modificado (sin fuente de azufre o dextrosa para evitar la proliferación de bacterias fermentativas u organismos púrpuras del azufre). Argón fue empleado para mantener condiciones anaerobias durante la fase de enriquecimiento. Las botellas fueron incubadas a $3 \mathrm{kLux}$ en una cámara iluminada con lámparas de halógeno de 50W (con un flujo de $57 \mu \mathrm{mol} \mathrm{m}^{-2} \mathrm{~s}^{-1}$ ) y LEDs (con un flujo de $44 \mu \mathrm{mol} \mathrm{m}{ }^{-2}$ $\left.\mathrm{s}^{-1}\right)$, .La temperatura se reguló a $30^{\circ} \mathrm{C}$.

Una vez que el cultivo creció, fue propagado transfiriendo $5 \mathrm{~mL}$ del cultivo rojizo en $85 \mathrm{~mL}$ de medio mineral Pfennig fresco e incubado bajo las condiciones arriba mencionadas cada dos semanas completando un total de 6 subsecuentes propagaciones. El cultivo fotoheterótrofo enriquecido (Cultivo IZT) resultante fue empleado en este trabajo (ver apéndice 1).

El cultivo de $R$. capsulatus ATCC 17015 fue obtenido de la colección bacteriológica ATCC. Este también fue cultivado en medio Pfennig modificado.

\subsubsection{Preparación del medio Pfennig para la propagación y conservación de los cultivos}

El medio mineral Pfennig modificado utilizado para el enriquecimiento y propagación de los cultivos fotoheterótrofos fue preparado con los reactivos mencionados en la tabla 1. En un frasco para esterilizar se colocaron $500 \mathrm{~mL}$ de agua destilada y se agregaron el $\mathrm{NH}_{4} \mathrm{Cl}, \mathrm{MgSO}_{4}$, extracto de levadura y $18 \mathrm{~mL}$ de la solución de elementos traza. En frascos de $125 \mathrm{~mL}$ con $100 \mathrm{~mL}$ de agua se colocó por separado el $\mathrm{CaCl} .2 \mathrm{H}_{2} \mathrm{O}, \mathrm{KH}_{2} \mathrm{PO}_{4}, \mathrm{KCl}, \mathrm{NaHCO}_{3}$ y $\mathrm{CH}_{3} \mathrm{COONa}$, y se esterilizaron. Una vez que las soluciones alcanzaron la temperatura ambiente se mezclaron y, finalmente se agregó la vitamina B12. Como fuente de carbono se empleó ácido acético y butírico 15mM. En botellas serológicas de $125 \mathrm{~mL}$ se colocaron $90 \mathrm{~mL}$ de medio, se sellaron con tapón de goma y arillo metálico. 
El espacio gaseoso se purgó con argón por 3 minutos a 15 psi. Las botellas se dejaron a prueba de esterilidad por 3 días antes de emplearse.

Tabla 2.1. Componentes del medio Pfennig modificado

\begin{tabular}{|c|c|c|c|}
\hline \multicolumn{2}{|c|}{ Medio Pfennig Modificado } & \multicolumn{2}{|c|}{ Solución de elementos Traza } \\
\hline $\mathrm{CaCl} .2 \mathrm{H}_{2} \mathrm{O}$ & $257 \mathrm{mg}$ & EDTA & $500 \mathrm{mg}$ \\
\hline $\mathrm{KH}_{2} \mathrm{PO}_{4}$ & $350 \mathrm{mg}$ & $\mathrm{FeSO}_{4} .7 \mathrm{H}_{2} \mathrm{O}$ & $200 \mathrm{mg}$ \\
\hline $\mathrm{NH}_{4} \mathrm{Cl}$ & $350 \mathrm{mg}$ & $\mathrm{ZnSO}_{4} .7 \mathrm{H}_{2} \mathrm{O}$ & $10 \mathrm{mg}$ \\
\hline $\mathrm{KCl}$ & $350 \mathrm{mg}$ & $\mathrm{MnCl}_{2} \cdot 4 \mathrm{H}_{2} \mathrm{O}$ & $3 \mathrm{mg}$ \\
\hline $\mathrm{MgSO}_{4}$ & $514 \mathrm{mg}$ & $\mathrm{H}_{3} \mathrm{BO}_{3}$ & $30 \mathrm{mg}$ \\
\hline $\mathrm{NaHCO}_{3}$ & $1500 \mathrm{mg}$ & $\mathrm{CoCl}_{2} \cdot 6 \mathrm{H}_{2} \mathrm{O}$ & $20 \mathrm{mg}$ \\
\hline $\mathrm{CH}_{3} \mathrm{COOH}$ & $30 \mathrm{mM}$ & $\mathrm{CuCl}_{2} \cdot 2 \mathrm{H}_{2} \mathrm{O}$ & $1 \mathrm{mg}$ \\
\hline Extracto de levadura & $100 \mathrm{mg}$ & $\mathrm{NiCl}_{2} .6 \mathrm{H}_{2} \mathrm{O}$ & $2 \mathrm{mg}$ \\
\hline Solución traza & $18 \mathrm{~mL}$ & $\mathrm{Na}_{2} \mathrm{MoO}_{4} \cdot 2 \mathrm{H}_{2} \mathrm{O}$ & $3 \mathrm{mg}$ \\
\hline Vitamina B12 & $0.3 \mathrm{~mL}$ & & \\
\hline
\end{tabular}

\subsubsection{Diseño experimental.}

Se evaluó la influencia de cuatro factores sobre la producción de hidrógeno a través de un diseño factorial completo con sus respectivos niveles: factor tipo de inoculo (con dos niveles: $R$. capsulatus y cultivo IZT); método para purgar el headspace (con tres niveles: $\mathrm{Ar}, \mathrm{CO}_{2}$ y presión reducida); factor adición de $\mathrm{NaHCO}_{3}$ (con 0, 250 y $500 \mathrm{mg} \mathrm{L-1}$ ); y factor condiciones de incubación (bajo condiciones controladas y ambientales). Las variables de respuesta fueron: la producción acumulada de hidrógeno (Pacum $\mathrm{H}_{2}$ ) en $\mathrm{mL} \mathrm{L}^{-1}$ de DFE diluido, la eficiencia de conversión del sustrato ECS (\%), la remoción de AGVs (\%), la remoción de DQO (\%) y la acumulación de PHB (gPHB g-1 peso seco). La ECS (\%) fue calculada como el cociente entre el hidrógeno producido experimentalmente y el valor teórico (4 mol $\mathrm{H}_{2}$ mol-1 $^{-1}$ acetato, $7 \mathrm{~mol} \mathrm{H}_{2} \mathrm{~mol}^{-1}$ propiónico, $10 \mathrm{~mol} \mathrm{H}_{2} \mathrm{~mol}^{-1}$ butírico). Para el diseño del experimento, análisis de resultados y gráficos se utilizó el software Desing Expert v 7.1.5. En este software se vaciaron los valores para las variables de respuesta, posteriormente se realizó el análisis 
de varianza (ANOVA). Para visualizar claramente que factores tuvieron efecto sobre las variables de respuesta se hizo el análisis por efectos principales. El ANOVA, a través de la prueba de Fisher's, se usó para evaluar el efecto de los factores sobre las variables de respuesta. Los valores de $p$ menores a 0.05 fueron aceptados como significativos. El análisis de residuales fue llevado a cabo para confirmar que se cumplieran los supuestos del ANOVA. Adicionalmente, se construyeron gráficas de "One Factor Effect" para cada factor probado.

\subsubsection{Efluente de fermentación oscura (DFE).}

El sustrato utilizado para la producción de hidrógeno fue un efluente de fermentación oscura de residuos de frutas y verduras donados por la Dra. Inés García Peña de la Unidad Profesional Interdisciplinaria de Biotecnología del IPN. La composición detallada de este efluente se muestra en la tabla 2.2.

La fermentación oscura se llevo a cabo en lote en un reactor escala piloto de $30 \mathrm{~L}$ (Bio-Dynamics Eili, modelo BDE 30) y se trabajo a un volumen de $15 \mathrm{~L}$. En el reactor se colocaron $5.0 \mathrm{~L}$ de residuos de frutas y verduras (plátano, piña, naranja, papaya, jitomate y lechuga en proporciones iguales) previamente molidos, $8.5 \mathrm{~L}$ de agua y las siguientes sales: $\left(\mathrm{NH}_{4}\right)_{2} \mathrm{PO}_{4} 3.0 \mathrm{~g} / \mathrm{L}, \mathrm{KH}_{2} \mathrm{PO}_{4} 0.6 \mathrm{~g} / \mathrm{L}, \mathrm{K}_{2} \mathrm{HPO}_{4}$

$2.4 \mathrm{~g} / \mathrm{L}, \mathrm{MgSO}_{4} \cdot 7 \mathrm{H}_{2} \mathrm{O} 1.5 \mathrm{~g} / \mathrm{L}, \mathrm{CaSO}_{4} 0.15 \mathrm{~g} / \mathrm{L}$ y FeSO${ }_{4} 0.03 \mathrm{~g} / \mathrm{L}$, finalmente $1.5 \mathrm{~L}$ de inoculo metanogénico previamente tratado a $80^{\circ} \mathrm{C}$ por $30 \mathrm{~min}$. La fermentación operó a $35^{\circ} \mathrm{C}$, con control automático de pH a 5.5. La fermentación se mantuvo por 122 horas y la concentración de hidrógeno en el biogás fue alrededor del $40 \%$. 
Tabla 2.2. Composición del DFE empleado como sustrato en los ensayos de foto-fermentación

\begin{tabular}{lr}
\hline Componente & \multicolumn{1}{l}{ Concentración } \\
\hline $\begin{array}{l}\text { Ácido butírico } \\
\text { Ácido propiónico }\end{array}$ & $11.61 \pm 0.26\left(\mathrm{~g} \mathrm{~L}^{-1}\right)$ \\
Ácido acético & $1.76 \pm 0.23\left(\mathrm{~g} \mathrm{~L}^{-1}\right)$ \\
$\mathrm{NH}_{4}^{+}$ & $780 \pm 0.08\left(\mathrm{~g} \mathrm{~L}^{-1}\right)$ \\
$\mathrm{TOC}$ & $9600 \pm 613\left(\mathrm{mg} \mathrm{L}^{-1}\right)$ \\
$\mathrm{NT}$ & $903 \pm 156\left(\mathrm{mg} \mathrm{L}^{-1}\right)$ \\
$\mathrm{C} / \mathrm{N}$ & 10.63 \\
$\mathrm{DQO}$ & $30.6 \pm 0.4\left(\mathrm{~g} \mathrm{~L}^{-1}\right)$ \\
DQO & $55.24\left(\mathrm{~g} \mathrm{~L}^{-1}\right)$ \\
ST & $313 \pm 9\left(\mathrm{mg} \mathrm{L}^{-1}\right)$ \\
SV & $253 \pm 19\left(\mathrm{mg} \mathrm{L}^{-1}\right)$ \\
La DQO & \\
orgánica diferente a AGVs. TOC: Carbono orgánico total, TN: Nitrógeno \\
total, C/N: cociente carbono/nitrógeno, ST: Sólidos totales, SV: Sólidos \\
volátiles.
\end{tabular}

\subsubsection{Pruebas de producción de hidrógeno en lote.}

Los experimentos fueron llevados a cabo en botellas serológicas de $120 \mathrm{~mL}$ con $69 \mathrm{~mL}$ de agua potable y $7 \mathrm{~mL}$ de DFE no estéril previamente centrifugado a $4000 \mathrm{rpm}$ por $10 \mathrm{~min}$. El efluente diluido fue suplementado con $\mathrm{NaHCO}_{3}\left(0,250\right.$ o $500 \mathrm{mg} \mathrm{L}^{-1}$ según correspondiera) y el pH fue ajustado a 7.0 con una solución $0.5 \mathrm{M}$ de $\mathrm{NaOH}$. Posteriormente $4.5 \mathrm{~mL}$ de un buffer de fosfatos $420 \mathrm{mM}$ fue adicionado.

Las botellas fueron selladas con tapones de acrilonitrilo y arillo metálico, Argón o $\mathrm{CO}_{2}$ fueron usados para purgar el aire del headspace. En los tratamientos a presión reducida $(8.5 \mathrm{~cm} \mathrm{Hg})$ el aire del 
espacio de cabeza de los viales fue removido a través de una aguja insertada en el tapón y conectada a una bomba de vacío.

Todas las botellas fueron inoculadas con $5 \mathrm{~mL}$ del cultivo IZT o $R$. capsulatus (equivalente a $0.001 \mathrm{~g}$ $\mathrm{L}^{-1}$ de proteína) e inicialmente fueron incubadas bajo condiciones controladas en una cámara iluminada con LEDs y lámparas de halógeno con iluminación continua a $3 \mathrm{kLux}$ y $30 \pm 3{ }^{\circ} \mathrm{C}$. Después de 5 días, la mitad de los minireactores se colocaron bajo una malla sombra en condiciones ambientales. Cada tratamiento se hizo por duplicado. Los tratamientos en condiciones ambientales fueron realizados durante el verano en la Ciudad de México.

Dependiendo de cada tratamiento, y para evitar el consumo de hidrógeno por la hidrogenasa, la presión del headspace fue reducida a $8.5 \mathrm{~cm} \mathrm{Hg}$, o purgado con $\mathrm{Ar} \circ \mathrm{CO}_{2}$ cada 3 días o cuando la presión del hedspace incremento por la generación de biogás. Los experimentos concluyeron cuando la producción de hidrógeno ceso.

La tasa específica de producción de hidrógeno fue obtenida por ajuste de los datos experimentales a la ecuación de Gompertz.

\subsubsection{Métodos analíticos.}

La composición de biogás se determinó utilizando un cromatógrafo de gases (Gow Mac modelo 550) equipado con un detector de conductividad térmica (TCD) y una columna de silica-gel 60/80 (Alltech) $18^{\prime} \times 1 / 8^{\prime} \times 0.085^{\prime \prime}$. La temperatura de la columna fue de $30^{\circ} \mathrm{C}$, la del inyector y detector fueron de $75^{\circ} \mathrm{C}$ y $120^{\circ} \mathrm{C}$ respectivamente; y la corriente del detector $85 \mathrm{~mA}$. El nitrógeno fue utilizado como acarreador a un flujo de $30 \mathrm{~mL} \mathrm{min-1}$. El volumen de hidrógeno producido fue ajustado a condiciones de presión y temperatura normales $\left(1 \mathrm{~atm}\right.$ y $\left.0^{\circ} \mathrm{C}\right)$. 
Para determinar la concentración de biomasa expresada como $\mathrm{g}$ de proteína $\mathrm{L}^{-1}$ de cultivo se empleó el método de Lowry, utilizando el kit Protein Assay $\odot$ de BIO RAD DC, USA. Se tomó $1 \mathrm{~mL}$ de muestra (por duplicado) y se centrifugó a 13000 rpm por 8 minutos, al pellet se le adicionó $1 \mathrm{~mL}$ de $\mathrm{NaOH} 0.2$ $\mathrm{N}$ y se agitó. Posteriormente se sometió a baño María por 15 min y una vez a temperatura ambiente se transfirieron $200 \mu \mathrm{L}$ a otro tubo y se agregó $100 \mu \mathrm{L}$ del reactivo A y 800 del B, se agitó en vortex y guardo en oscuridad por 15 min. Enseguida se tomó lectura de las muestras en un espectrofotómetro a $750 \mathrm{~nm}$.

La composición y consumo de AGVs se determinó por cromatografía de gases en un cromatógrafo Hewlett Packard 5890 Serie II con detector de ionización de flama (FID) equipado con una columna capilar AT1000 (15m x $0.53 \mathrm{~mm}$ ID, $1.23 \mu \mathrm{m}$ film). Las temperaturas del inyector y detector fueron 200 ${ }^{\circ} \mathrm{C}$. La temperatura del horno se mantuvo por 2 min a $80^{\circ} \mathrm{C}$, incrementando a $200^{\circ} \mathrm{C}$ a $15^{\circ} \mathrm{C} \mathrm{min}-1$, y después constante a $200{ }^{\circ} \mathrm{C}$ por 1 min. Como gas de arrastre se empleó nitrógeno a un flujo de 6 $\mathrm{mL} \mathrm{min}{ }^{-1}$. Las muestras a analizar se filtraron a través de una membrana de $0.2 \mu \mathrm{m}$, posteriormente acidificadas con $\mathrm{HCl}$ y finalmente inyectadas en el cromatógrafo para medir la concentración de ácidos libres.

La determinación cuantitativa de PHB se llevó a cabo por cromatografía de gases de acuerdo a Zuñiga et al. (2011). Las muestras (3 mL) de los cultivos líquidos se centrifugaron a 13,000rpm por $8 \mathrm{~min}$. El sobrenadante se desechó y al pellet de biomasa se le agregaron $0.8 \mathrm{~mL}$ de propanol, $0.2 \mathrm{~mL}$ de $\mathrm{HCl}$ y $2 \mathrm{~mL}$ de cloroformo, se incubó $4 \mathrm{~h}$ a 100 •C. Después de enfriar a temperatura ambiental, se agregó $1 \mathrm{~mL}$ de agua desionizada y agitó en vortex. Enseguida de la separación de las dos fases, se recuperó la fase orgánica (abajo), se filtro en membrnas de nylon y $1 \mu \mathrm{L}$ de muestras se analizó por cromatografía de gases usando un GC-FID Agilent 6890N (Agilent Technologies, Santa Clara, CA, USA). Las temperaturas del horno, inyector y detector fueron 160,200 , y $250 \circ \mathrm{C}$, respectivamente. 
El carbono orgánico total soluble (TOC) del DFE fue determinado en un equipo Shimatzu TOC-500. Los sólidos volátiles (SV) fueron determinados por métodos estándar (APHA-AWWA-WPCF, 1992). El nitrógeno amoniacal fue determinado con el kit $\mathrm{HACH} \mathrm{NI-8} \mathrm{y} \mathrm{de} \mathrm{acuerdo} \mathrm{a} \mathrm{las} \mathrm{instrucciones} \mathrm{del}$ fabricante. La intensidad luminosa fue medida con el equipo Extech Instruments407026sp modelo 2.2, USA.

\subsection{Resultados y discusión}

La tabla 2.3 muestra los resultados del diseño experimental para evaluar el efecto del tipo de inóculo, método de purgado del headspace, adición de $\mathrm{NaHCO}_{3}$ y condiciones de incubación sobre la Paccum $\mathrm{H}_{2}$, la remoción de $\mathrm{DQO}$, la acumulación de $\mathrm{PHB}$, la eficiencia de conversión del sustrato, y la remoción de AGVs. Se llevó a cabo un análisis de varianza de estos datos para evaluar la significancia estadística de los factores arriba mencionados sobre las variables de respuesta $\mathrm{Paccum} \mathrm{H}_{2}$, remoción de DQO y acumulación de PHB, los resultados se muestran en la tabla 2.4. Los valores de F obtenidos para el análisis indican que el modelo fue significativo, con un valor de $p<0.01 \%$. Los valores de $p$ son una medida de la significancia estadística de cada variable; bajos valores de $p$ corresponden a una alta significancia estadística de las variables con el modelo. En este trabajo, valores de $p$ menores a 0.05 fueron aceptados como significativos. Una discusión para cada factor es presentada en las siguientes secciones. 
Tabla 2.3. Resultados para las variables de respuesta de cada uno de los tratamientos con el cultivo IZT o R. capsulatus bajo condiciones controladas o ambientales.

\begin{tabular}{|c|c|c|c|c|c|c|c|c|c|c|}
\hline \multirow{2}{*}{$\begin{array}{c}\text { Variable } \\
\text { de } \\
\text { respuesta } \\
\text { Cultivo }\end{array}$} & \multicolumn{2}{|c|}{$\begin{array}{l}\text { Paccum } \mathrm{H}_{2} \\
\left(\mathrm{~mL} \mathrm{~L}^{-1}\right)\end{array}$} & \multicolumn{2}{|c|}{ ECS (\%) } & \multicolumn{2}{|c|}{$\begin{array}{c}\text { Remoción de AGVs } \\
(\%)\end{array}$} & \multicolumn{2}{|c|}{ Remoción de DQO (\%) } & \multicolumn{2}{|c|}{$\begin{array}{c}\text { Acumulación de PHB (mg } \\
\text { peso seco') }\end{array}$} \\
\hline & R. caps & IZT & R. caps. & IZT & R. caps. & IZT & R. caps & IZT & R. caps. & IZT \\
\hline \multicolumn{11}{|c|}{ Tratamientos bajo condiciones controladas } \\
\hline Ar-N & $320 \pm 423$ & $830 \pm 23$ & $10 \pm 14$ & $27 \pm 1$ & $63 \pm 3$ & $72 \pm 1$ & $47 \pm 3$ & $72 \pm 0$ & $68 \pm 4$ & $165 \pm 13$ \\
\hline Ar-M & $1032 \pm 33$ & $1120 \pm 49$ & $33 \pm 1$ & $36 \pm 2$ & $100 \pm 0$ & $90 \pm 0$ & $58 \pm 1$ & $78 \pm 1$ & $98 \pm 2$ & $63 \pm 8$ \\
\hline $\mathrm{Ar}-\mathrm{H}$ & $1003 \pm 1$ & $850 \pm 50$ & $32 \pm 0$ & $27 \pm 2$ & $100 \pm 0$ & $81 \pm 0$ & $53 \pm 1$ & $72 \pm 1$ & $89 \pm 4$ & $69 \pm 4$ \\
\hline $\mathrm{CO}_{2}-\mathrm{N}$ & $877 \pm 427$ & $553 \pm 29$ & $28 \pm 14$ & $18 \pm 1$ & $100 \pm 0$ & $88 \pm 0$ & $57 \pm 0$ & $54 \pm 0$ & $137 \pm 12$ & $105 \pm 6$ \\
\hline $\mathrm{CO}_{2}-\mathrm{M}$ & $1105 \pm 15$ & $795 \pm 38$ & $36 \pm 0$ & $26 \pm 1$ & $100 \pm 0$ & $94 \pm 0$ & $65 \pm 1$ & $62 \pm 1$ & $79 \pm 4$ & $48 \pm 6$ \\
\hline $\mathrm{CO}_{2}-\mathrm{H}$ & $1088 \pm 38$ & $469 \pm 53$ & $35 \pm 1$ & $15 \pm 2$ & $100 \pm 0$ & $92 \pm 0$ & $32 \pm 0$ & $48 \pm 0$ & $19 \pm 1$ & $51 \pm 1$ \\
\hline RP-N & $799 \pm 480$ & $1127 \pm 10$ & $26 \pm 15$ & $36 \pm 0$ & $100 \pm 0$ & $100 \pm 0$ & $73 \pm 1$ & $89 \pm 0$ & $38 \pm 3$ & $51 \pm 13$ \\
\hline RP-M & $1252 \pm 20$ & $1478 \pm 17$ & $40 \pm 1$ & $48 \pm 1$ & $100 \pm 0$ & $100 \pm 0$ & $65 \pm 0$ & $89 \pm 1$ & $53 \pm 3$ & $27 \pm 1$ \\
\hline RP-H & $1249 \pm 61$ & $1289 \pm 47$ & $40 \pm 2$ & $41 \pm 2$ & $100 \pm 0$ & $98 \pm 0$ & $66 \pm 2$ & $86 \pm 2$ & $47 \pm 4$ & $36 \pm 2$ \\
\hline \multicolumn{11}{|c|}{ Tratamientos en condiciones ambientales } \\
\hline Ar-N & $294 \pm 195$ & $44 \pm 40$ & $9 \pm 6$ & $1 \pm 1$ & $63 \pm 3$ & $43 \pm 1$ & $29 \pm 1$ & $40 \pm 2$ & $84 \pm 5$ & $144 \pm 17$ \\
\hline Ar-M & $467 \pm 9$ & $632 \pm 38$ & $15 \pm 0$ & $20 \pm 1$ & $100 \pm 0$ & $68 \pm 1$ & $60 \pm 0$ & $55 \pm 1$ & $414 \pm 5$ & $47 \pm 4$ \\
\hline $\mathrm{Ar}-\mathrm{H}$ & $512 \pm 0$ & $512 \pm 6$ & $16 \pm 0$ & $16 \pm 0$ & $100 \pm 0$ & $60 \pm 0$ & $47 \pm 11$ & $49 \pm 0$ & $386 \pm 22$ & $47 \pm 4$ \\
\hline $\mathrm{CO}_{2}-\mathrm{N}$ & $18 \pm 5$ & $279 \pm 3$ & $1 \pm 0$ & $9 \pm 0$ & $49 \pm 0$ & $51 \pm 1$ & $24 \pm 2$ & $40 \pm 1$ & $60 \pm 3$ & $39 \pm 5$ \\
\hline $\mathrm{CO}_{2}-\mathrm{M}$ & $226 \pm 2$ & $523 \pm 38$ & $7 \pm 0$ & $17 \pm 1$ & $69 \pm 0$ & $76 \pm 1$ & $32 \pm 0$ & $53 \pm 2$ & $18 \pm 5$ & $39 \pm 5$ \\
\hline $\mathrm{CO}_{2}-\mathrm{H}$ & $182 \pm 9$ & $293 \pm 32$ & $6 \pm 0$ & $9 \pm 1$ & $72 \pm 1$ & $63 \pm 0$ & $57 \pm 2$ & $40 \pm 1$ & $145 \pm 2$ & $49 \pm 7$ \\
\hline RP-N & $417 \pm 170$ & $861 \pm 44$ & $13 \pm 5$ & $28 \pm 1$ & $78 \pm 1$ & $96 \pm 1$ & $71 \pm 1$ & $84 \pm 4$ & $44 \pm 5$ & $15 \pm 5$ \\
\hline RP-M & $866 \pm 46$ & $883 \pm 4$ & $28 \pm 1$ & $28 \pm 0$ & $100 \pm 0$ & $95 \pm 2$ & $68 \pm 4$ & $80 \pm 1$ & $299 \pm 9$ & $42 \pm 4$ \\
\hline RP-H & $812 \pm 32$ & $610 \pm 11$ & $26 \pm 1$ & $20 \pm 0$ & $100 \pm 0$ & $77 \pm 0$ & $68 \pm 1$ & $61 \pm 3$ & $265 \pm 14$ & $48 \pm 25$ \\
\hline
\end{tabular}

R. caps: Rhodobacter capsulatus, Ar: argon, RP:Presión reducida, N: $0 \mathrm{mg} \mathrm{L}^{-1} \mathrm{NaHCO}_{3}, \mathrm{M}: 250 \mathrm{mg} \mathrm{L}-1 \mathrm{NaHCO}_{3}, \mathrm{H:} 500 \mathrm{mg} \mathrm{L}^{-1} \mathrm{NaHCO}_{3}$ 
Tabla 2.4. Resumen de los resultados del ANOVA para las variables de respuesta Pacum $\mathrm{H}_{2}$, remoción de DQO y acumulación de PHB.

\begin{tabular}{|c|c|c|c|c|c|c|}
\hline \multirow{2}{*}{$\begin{array}{c}\text { Response variable } \\
\text { Factors } \\
\text { Model }\end{array}$} & \multicolumn{2}{|c|}{ Pacum $\mathrm{H}_{2}$} & \multicolumn{2}{|c|}{ PHB accumulation } & \multicolumn{2}{|c|}{ COD removal } \\
\hline & $\begin{array}{c}\text { F-value } \\
67.68\end{array}$ & $\begin{array}{l}p \text {-value } \\
<0.0001\end{array}$ & $\begin{array}{c}\text { F-value } \\
5.31\end{array}$ & $\begin{array}{l}p \text {-value } \\
0.0002\end{array}$ & $\begin{array}{c}\text { F-value } \\
27.8\end{array}$ & $\begin{array}{l}p \text {-value } \\
<0.0001\end{array}$ \\
\hline Inoculum type & 0.20 & 0.6600 & 12.09 & 0.0009 & 19.62 & $<0.0001$ \\
\hline Flushing Method & 66.79 & $<0.0001$ & 5.64 & 0.0056 & 55.03 & $<0.0001$ \\
\hline $\begin{array}{l}\text { Bicarbonate } \\
\text { concentration }\end{array}$ & 23.68 & $<0.0001$ & 0.52 & 0.5962 & 4.66 & 0.0130 \\
\hline $\begin{array}{l}\text { Incubation } \\
\text { conditions }\end{array}$ & 210.95 & $<0.0001$ & 6.37 & 0.0142 & 25.35 & $<0.0001$ \\
\hline
\end{tabular}

\subsubsection{Producción de hidrógeno.}

\subsubsection{Efecto del inóculo sobre la producción de hidrógeno}

El análisis de varianza mostrado en la tabla 2.4 indica que la Paccum $\mathrm{H}_{2}$ fue significativamente afectada $(p<0.05)$ por todos los factores (método de purgado del headspace $(p<0.0001)$, concentración de bicarbonato $(p<0.0001)$, y condiciones incubaciones $(p<<0.0001))$ excepto por el tipo de cultivo $(p=0.66)$. Para visualizar estas tendencias, la figura 2.1 muestra la Pacum $\mathrm{H}_{2}$ promedio para cada nivel de los factores evaluados. Las dos primeras columnas de la figura 2.1 corresponden al gráfico "one-factor-effect" para el inóculo. Como puede verse, los valores para $R$. capsulatus, 751 $\mathrm{ml} \mathrm{H} \mathrm{L}^{-1}$, y el cultivo IZT, $767 \mathrm{ml} \mathrm{H}_{2} \mathrm{~L}^{-1}$, fueron similares. Los dos cultivos tienen la misma capacidad para producir hidrógeno y generar biomasa, $0.2 \mathrm{~g}$ proteína $\mathrm{L}^{-1}$ en promedio. 


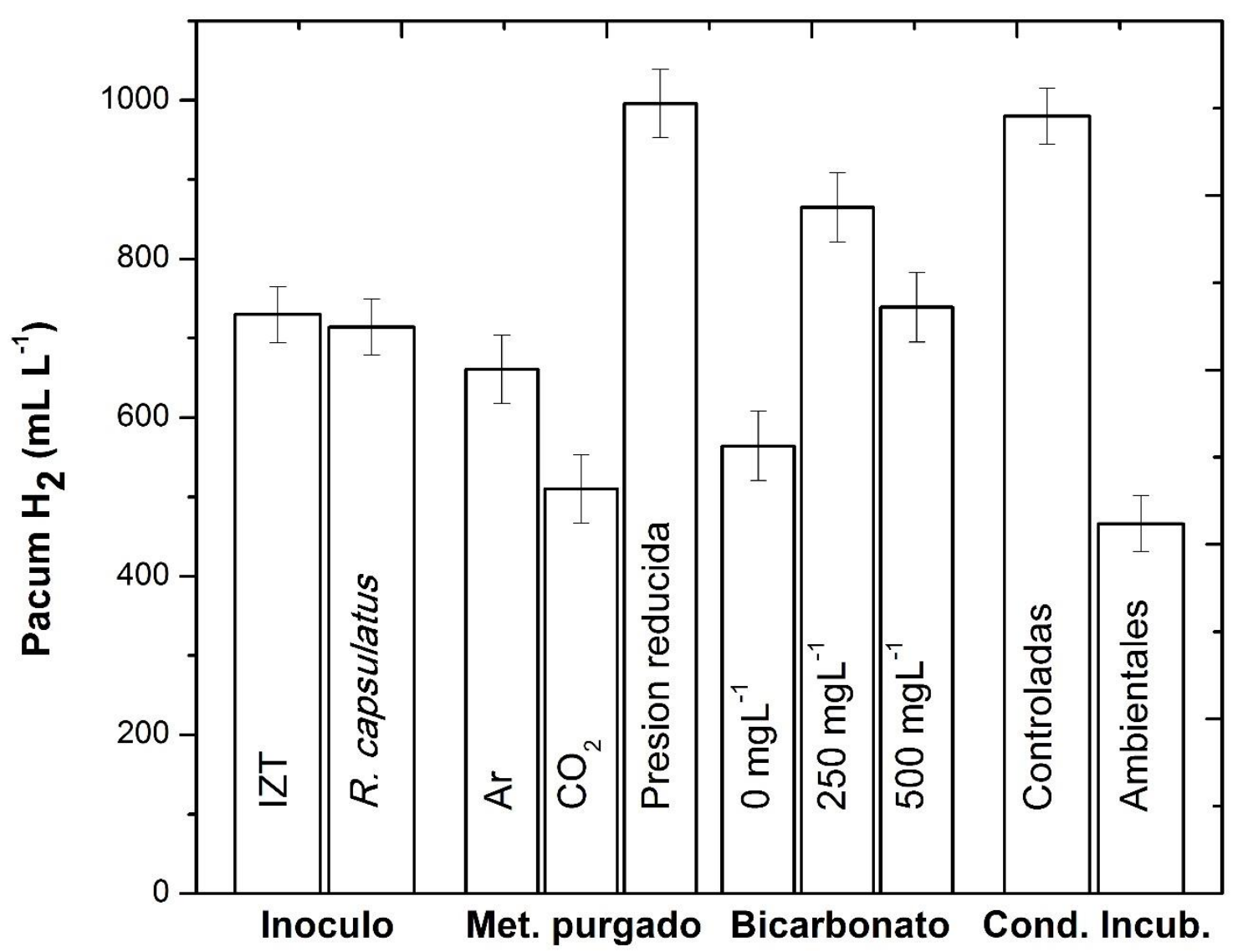

Figura 2.1. Compendio de cuatro gráficas "one-factor-effect" producidas en el análisis estadístico ANOVA. Cada grupo de barras denota el efecto de cambio de nivel de cada factor (inóculo, método de purgado del headspace, concentración de bicarbonato, y, condiciones de incubación) sobre la producción acumulada de hidrógeno.

La máxima Pacum $\mathrm{H}_{2}, 1478 \pm 17 \mathrm{~mL} \mathrm{H}_{2} \mathrm{~L}^{-1}$ con una ECS de $48 \%$, fue alcanzada por el tratamiento cultivo IZT - $250 \mathrm{mg} \mathrm{NaHCO}_{3} \mathrm{~L}^{-1}$ - presión reducida y condiciones de incubación controladas (ver figura 2.1 y tabla 2.3), la tasa de producción máxima fue de $6.5 \mathrm{ml} \mathrm{H}_{2} \mathrm{~L}^{-1} \mathrm{~h}^{-1}$ y la mayoría de la producción de hidrógeno (91\%) se alcanzó en los primeros 18 días.

La concentración de biomasa llegó hasta $0.3 \mathrm{~g}$ de proteína L-1 en la primera semana (ver figura 2.2), posiblemente, correlacionado con el contenido de nitrógeno inicial en el DFE diluido $\left(0,75 \mathrm{mg} \mathrm{N} \mathrm{L}^{-1}\right)$. 
El hidrógeno fue producido desde las etapas iniciales de la fermentación y su producción fue parcialmente asociada al crecimiento. En la figura 2.2 se puede observar que el ácido butírico se consume durante los primeros 11 días en la fase de crecimiento exponencial. Aunque no se detectaron AGV para ese día, la producción de $\mathrm{H}_{2}$ continuó durante 10 días más decayendo a partir de entonces. La disminución en las tasas de producción de $\mathrm{H}_{2}$ en la última fase de la fermentación fue debido al consumo de la materia orgánica remanente y más recalcitrante una vez que los fácilmente degradables AGVs del DFE se agotaron.

Al inicio de los experimentos la concentración de DQO fue $2.6 \mathrm{~g} \mathrm{~L}^{-1}$ y el contenido de AGVs fue $1 \mathrm{~g} \mathrm{~L}^{-1}$ de ácido butírico, $0.15 \mathrm{~g} \mathrm{~L}^{-1}$ de ácido propiónico y $0.1 \mathrm{~g} \mathrm{~L}^{-1}$ de ácido acético. En el caso del cultivo IZT, el ácido acético y propiónico fueron completamente consumidos en los primeros 3 días, mientras que el consumo del ácido butírico tomó más de 10 días; en ese momento el consumo de DQO fue $68 \%$, pero alcanzó el $89 \%$ al final del proceso.

$R$. capsulatus siguió la misma tendencia y produjo $1252 \pm 20 \mathrm{~mL} \mathrm{H}_{2} \mathrm{~L}^{-1}$ correspondiendo a ECS de $40 \%$ que fue $8 \%$ más baja que la que alcanzó el cultivo IZT. Una importante fracción, $94 \%$ de la producción de hidrógeno se alcanzó en los primeros 15 días de operación con una tasa de $5.7 \mathrm{~mL} \mathrm{H}$ $L^{-1} h^{-1}$ (ver figura $2.3 y$ tabla 2.3).

Comparado con datos publicados de producción de hidrógeno, los resultados obtenidos con el cultivo IZT fueron mejores que los obtenidos con un consorcio fotoheterótrofo obtenido de sedimentos de un lago de Brasil por Aparecida Loss et al. (2013) con una Pacum $\mathrm{H}_{2}$ de $143.6 \mathrm{~mL} \mathrm{~L}^{-1}$ (ECS de 5\%) y $135.4 \mathrm{~mL} \mathrm{~L}-1$ (ECS de 4\%) a partir de acetato y butirato, respectivamente. Lazaro et al. (2012) obtuvieron un consorcio bacteriano fotoheterótrofo productor de hidrógeno a partir de un lodo granular anaerobio de un reactor UASB para tratar aguas residuales de ganado porcino. Ellos obtuvieron una ECS del $15 \%$ para acetato y $14 \%$ para butirato con tasas de 0.4 y $0.9 \mathrm{~mL} \mathrm{H}_{2} \mathrm{~L}^{-1} \mathrm{~h}^{-1}$, respectivamente. Li et al. (2008) reportan remociones de acetato del $29 \%$ y $35 \%$ de butirato con una tasa de $5.7 \mathrm{~mL} \mathrm{H}$ 
$L^{-1} h^{-1}$ usando un lodo fotoheterótrofo enriquecido de un una muestra de sedimento obtenida de North River en China.

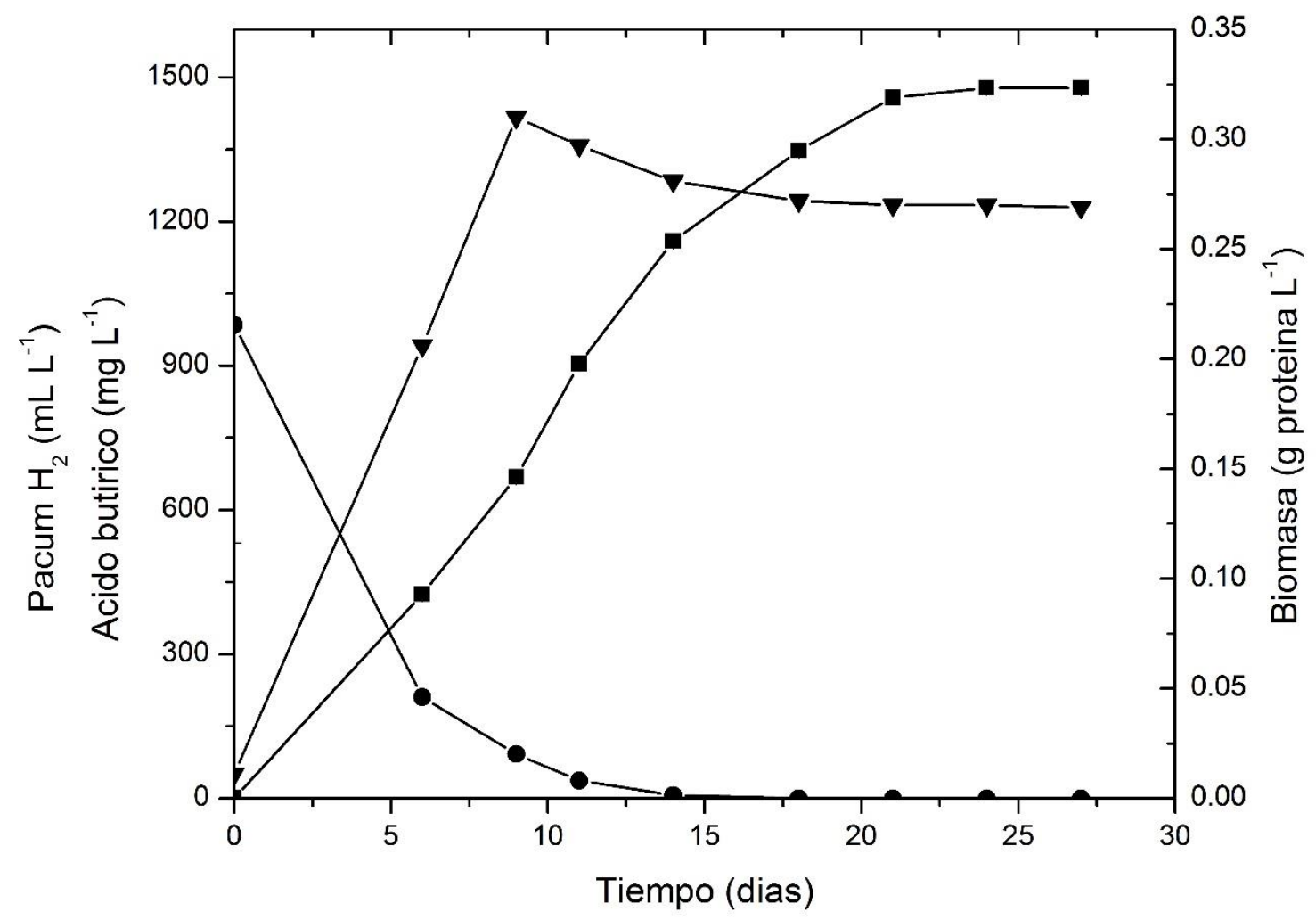

Figura 2.2. Cinéticas de producción de biomasa $(\boldsymbol{\nabla})$, Pacum $\mathrm{H}_{2}(\boldsymbol{\square})$ y remoción de ácido butírico $(\bullet)$ por el cultivo IZT bajo presión reducida, $250 \mathrm{mg} \mathrm{NaHCO}_{3} \mathrm{~L}^{-1}$ y condiciones de incubación controladas. Las barras de error no son visibles debido a que las desviaciones estándar son muy pequeñas.

\subsubsection{Efecto del método de purgado del headspace sobre la producción de hidrógeno.}

El segundo grupo de barras en la figura 2.1 muestra que presión reducida fue la mejor opción para mejorar la producción de hidrógeno (970 mL H2 L-1), comparado Argón (635 mL H2 L-1) o CO 2 (534 mL $\left.\mathrm{H}_{2} \mathrm{~L}^{-1}\right)$. 
Pocos autores han estudiado el efecto de presión reducida en el headspace de fotobiorreactores. Li et al. (2011) reportaron que la evacuación parcial del headspace incrementa la diferencia de presiones entre la fase líquida y gas y también reduce la solubilidad del $\mathrm{H}_{2}$ y $\mathrm{CO}_{2}$ en el medio, permitiendo la liberación de las burbujas de gas del medio, lo que promueve que el equilibrio de la reacción se desplace hacia los productos (Li et al., 2011). Estos autores observaron que la producción total de hidrógeno por $R$. sphaeroides ZX-5 usando una mezcla de ácido málico y glutámico incremento de 118 a $131 \mathrm{~mL} \mathrm{H}$ por cada $34 \mathrm{~mL}$ de medio y la ECS incrementó $9.5 \%$ con una disminución de la presión total en el fotobiorreactor de $1.08 \times 10^{5}$ a 0.94 x $10^{5} \mathrm{~Pa}$.

En este trabajo, la presión reducida fue 0.11 x $10^{5} \mathrm{~Pa}$ (Presión atmosférica en la Ciudad de México $0.78 \times 10^{5}$ - presión manométrica negativa de $0.66 \times 10^{5} \mathrm{~Pa}$ ), la Pacum $\mathrm{H}_{2}$ para el cultivo IZT se incrementó de $1120 \pm 49 \mathrm{~mL} \mathrm{H}_{2} \mathrm{~L}^{-1}$ (con Argón a presión atmosférica y $250 \mathrm{mg} \mathrm{L}^{-1}$ de $\mathrm{NaHCO}_{3}$ ) a $1478 \pm 17 \mathrm{~mL} \mathrm{H}_{2} \mathrm{~L}^{-1}$ (con presión reducida y $250 \mathrm{mg} \mathrm{L}^{-1}$ de $\mathrm{NaHCO}_{3}$ ) y la ECS de $36 \%$ a $48 \%$ bajo condiciones controladas (la ECS incrementó 12\%) (ver tabla 2.3). De manera similar, la presión reducida mejoro la producción de hidrógeno por $R$. capsulatus (Tabla 2.3).

Pauss et al. (1990) encontraron que, a pesar de su baja solubilidad, la concentración de hidrógeno en digestores fue de 40-70 veces más alta que los valores calculados a partir de las presiones parciales de $\mathrm{H}_{2}$ medidas y que el coeficiente de Henry. La presión reducida limita la disolución del hidrógeno evitando así su re-oxidación por la hidrogenasa (NiFe-hidrogenasa). Alternativamente, en un sistema cerrado usando atmósfera de Argón, la presión del gas aumenta conforme se produce el hidrógeno, favoreciendo la transferencia de masa al medio líquido y su consumo por la hidrogenasa.

Algunos otros reportes han probado presión reducida en sistemas usando diferentes organismos hidrogenogénicos en fermentación oscura y biofotolisis. En contraste con nuestros resultados, Markov et al. (1993) encontró que los rendimientos de hidrógeno por la cianobacteria Anabaena bajo vacío parcial fueron comparables a aquellos con atmósfera de Ar y Kataoka et al. (1997) y Clark et al. (2012) 
encontraron que en fermentación oscura la presión del headspace por abajo de los niveles atmosféricos no tuvo efecto positivo sobre la producción de hidrógeno. Por lo tanto, esto sugiere que la presión reducida tiene efectos variables sobre la producción de $\mathrm{H}_{2}$ dependiendo del microorganismo productor de $\mathrm{H}_{2}$ en particular.

Sobre la base de nuestras observaciones y otros resultados, se podría postular que la presión reducida mejora la producción de hidrógeno en el proceso de foto-fermentación tanto por mantener condiciones anaeróbicas y por remover el hidrógeno como éste se va produciendo, lo que permite mantener baja presión parcial de hidrógeno y por lo tanto desplazar el equilibrio de la reacción hacia la formación de $\mathrm{H}_{2}$.

Con respecto al purgado con $\mathrm{CO}_{2}$, se observó que estos tratamientos tuvieron la producción de hidrógeno más baja (Fig. 2.1 y la Tabla 2.3), aunque no se inhibió completamente. Los reactores purgados con $\mathrm{CO}_{2}$ también mostraron los $\mathrm{pH}$ finales más bajos, en el rango de 6.1-6.6, los cuales no son adecuados para la producción de hidrógeno. En experimentos previos, se observó que a pH de 6,5, la producción de $\mathrm{H}_{2}$ era muy baja, llegando a ser nula a pH 6 (ver apéndice 1). Microorganismos neutrófilos tienden a bombear iones de hidrógeno fuera de la célula para mantener un nivel constante de fuerza motriz de protones cuando se encuentran a un entorno ácido. Este mecanismo reduce el contenido intracelular de iones hidrógeno y resulta en una baja producción de hidrógeno a pH 6.0 (Wu et al., 2012).

Liu et al (2009) estudiaron el efecto del $\mathrm{Ar}, \mathrm{N}_{2}, \mathrm{CO}_{2}$ y aire sobre la producción de hidrógeno por Rhodopseudomonas faecallis RLD-53. Ellos observaron que la tasa de crecimiento específico y producción de hidrógeno más altas se obtuvieron con $5 \%$ de $\mathrm{CO}_{2}$ (y 95\% argón) en el headspace, las tasas descendieron conforme la concentración de $\mathrm{CO}_{2}$ aumentó, con una total inhibición a $60 \%$ de $\mathrm{CO}_{2}$ usando acetato como sustrato (el acetato no requiere un aceptor de electrones para ser consumido). En este trabajo, hubo producción de hidrógeno aún con $100 \%$ de $\mathrm{CO}_{2}$ en el headspace 
pero, conforme la incubación procedió, el pH descendió y acoplado a un bajo consumo de $\mathrm{CO}_{2}$, provocaron una reducción en la producción de $\mathrm{H}_{2}$. Se sabe que la dilución del $\mathrm{CO}_{2}$ con argón es una posible solución como Liu et al. (2009) lo hicieron; sin embargo, se dificulta la purificación del $\mathrm{H}_{2}$, por lo que la adición de bicarbonato (véase la sección "Efecto de la adición de $\mathrm{NaHCO}_{3}$ sobre la producción de hidrógeno") podría ser una alternativa para proporcionar un aceptor de electrones.

\subsubsection{Efecto de la adición de $\mathrm{NaHCO}_{3}$ sobre la producción de hidrógeno}

La adición de bicarbonato al DFE tuvo efecto significativo sobre la producción de hidrógeno para ambos cultivos. Este efecto puede verse claramente en el tercer grupo de barras de la figura 2.1, donde la Pacum $\mathrm{H}_{2}$ promedio fue 739,865 y $577 \mathrm{~mL} \mathrm{H}_{2} \mathrm{~L}^{-1}$ para los tratamientos con 500,250 y $0 \mathrm{mg}$ $\mathrm{L}^{-1}$ de $\mathrm{NaHCO}_{3}$, respectivamente. La adición de bicarbonato mejoró tanto la producción de hidrógeno como el consumo de ácido butírico.

De los resultados de la tabla 2.3 se puede ver que en los tratamientos no suplementados con bicarbonato y purgados con Argón (tratamiento Ar-N) la remoción de ácido butírico fue incompleta y la producción de hidrógeno baja para $R$. capsulatus y el cultivo IZT bajo ambas condiciones, controladas y ambientales. De hecho, el tratamiento $R$. capsulatus-Ar-N en condiciones controladas presentó la remoción de AGVs y Paccum $\mathrm{H}_{2}$ más bajas, $63 \%$ y $320 \mathrm{~mL} \mathrm{~L}^{-1}$, respectivamente. El ión carbonato desempeñan un papel fundamental como un aceptor de electrones cuando se utiliza ácido butírico como sustrato, su ausencia limita la absorción de ácido propiónico y butírico debido al desequilibrio en el potencial redox. Muller (1933) reportó que por cada mol de butirato consumido durante el crecimiento bacteriano de BPNS se requiere el consumo de 0.7 mol de $\mathrm{CO}_{2}$. Ormerod (1962) encontró valores similares.

Durante condiciones de crecimiento quimioautotróficas y fotoautotróficas, las BPNS utilizan el ciclo Calvin-Benson-Bassham (CBB) para la reducción de $\mathrm{CO}_{2}$ en biomasa. En contraste, durante 
condiciones de crecimiento fotoheterotróficas el $\mathrm{CO}_{2}$ es el aceptor de electrones preferido cuando un compuesto de carbono orgánico sirve como principal fuente de carbono y como donador de electrones. La fijación de $\mathrm{CO}_{2}$ por el ciclo de $\mathrm{CBB}$ durante el modo de crecimiento fotoheterotrófico es requerido para sustratos que tienen un estado de oxidación más bajo que los componentes celulares, por lo tanto es absolutamente necesario la adición de $\mathrm{CO}_{2} \mathrm{O}$ algún otro aceptor de electrones oxidado para el crecimiento sobre un sustrato reducido como el butirato (Laguna et al., 2010).

$\mathrm{C}_{4} \mathrm{H}_{8} \mathrm{O}_{2}+\mathrm{CO}_{2}+\mathrm{H}_{2} \mathrm{O} \rightarrow 5\left[\mathrm{CH}_{2} \mathrm{O}\right]$

Takabatake et al. (2004) observaron que el carbonato promovió el consumo del ácido butírico y el crecimiento microbiano, lo que se tradujo en una importante producción de $\mathrm{H}_{2}$. También observaron que el cultivo mixto de bacterias fotoheterótrofas que emplearon no creció cuando utilizaron carbonato de sodio como la única fuente de carbono. Lo que indica que el carbonato no se utilizó como una fuente de carbono para el crecimiento microbiano.

Por otro lado, las BPNS crecen más rápido con fuentes de carbono orgánicas, tales como ácidos dicarboxílicos $\mathrm{C}_{4}$, que con $\mathrm{CO}_{2}$. La fijación fotosintética de $\mathrm{CO}_{2}$ no es necesaria y puede ser suprimida cuando compuestos orgánicos están disponibles para su directa asimilación (Ormerod, 1962). Por otro lado, las PNSB puede volver a asimilar el $100 \%$ del $\mathrm{CO}_{2}$ generado a partir de la oxidación sustratos orgánicos reducidos e incluso $\mathrm{CO}_{2} \circ$ bicarbonato adicional puede ser necesario (Ormerod, 1956; Muller, 1933; Kontur et al., 2012).

En este trabajo, se demostró que la adición de bicarbonato no modifica la producción de biomasa a pesar de que tuvo un efecto positivo sobre la producción de $\mathrm{H}_{2}$. El sustrato complejo (DFE) estimuló el crecimiento de las PNSB, pero al parecer sólo el uso de bicarbonato mantuvo el equilibrio redox de las células por más tiempo permitiéndoles producir más hidrógeno. 
A pesar de este conocimiento, en muchas investigaciones no han utilizado bicarbonato para mejorar la producción de hidrógeno. Este es uno de los primeros trabajos que han estudiado la adición de bicarbonato para la producción de hidrógeno empleando efluentes de fermentación oscura como sustrato.

\subsubsection{Efecto de las condiciones de incubación sobre la producción de hidrógeno.}

La figura 2.1 muestra que el promedio de producción de hidrógeno para los experimentos expuestos a condiciones ambientales fue cerca de la mitad $\left(480 \mathrm{~mL} \mathrm{H}_{2} \mathrm{~L}^{-1}\right)$ de la producción de hidrógeno de los tratamientos incubados en condiciones controladas de laboratorio.

La figura 2.3 muestra que la Paccum $\mathrm{H}_{2}$ promedio fue alrededor de $350 \mathrm{~mL} \mathrm{H}_{2} \mathrm{~L}^{-1}$ para el cultivo IZT y $R$. capsulatus en los primeros 5 días cuando estuvieron incubados a $30^{\circ} \mathrm{C}$ y $3 \mathrm{kLux}$, pero la producción de hidrógeno para la mitad de los tratamientos disminuyó después de que fueron expuestos a condiciones ambientales. Se observó que ambos cultivos en condiciones ambientales acumularon cantidades similares de $\mathrm{H}_{2}$ (883 \pm 4 y $866 \pm 46 \mathrm{~mL} \mathrm{H}_{2} \mathrm{~L}^{-1}$, respectivamente).

Los factores críticos bajo condiciones ambientales fueron las fluctuaciones de temperatura, altas intensidades luminosas, además de los ciclos luz-oscuridad naturales. Durante el experimento la temperatura varió entre 12 y $30^{\circ} \mathrm{C}$ y la intensidad luminosa máxima fue de 60 kLux bajo la malla sombra (ver figura 2.4).

Boran et al. (2010) observaron que fluctuaciones de temperatura entre 5 y $35{ }^{\circ} \mathrm{C}$ afectaron la producción de hidrógeno: cuando la temperatura se mantuvo por alrededor de $20^{\circ} \mathrm{C}$, la producción de $\mathrm{H}_{2}$ fue muy baja y por debajo de $15^{\circ} \mathrm{C}$ no hubo producción de $\mathrm{H}_{2}$. Avcioglu et al. (2011) observaron una relación directa entre la producción de hidrógeno y la radiación solar en $R$. capsulatus. Otros investigadores han demostrado se produce poco o nada de hidrógeno durante los periodos de oscuridad (Li et al., 2011), esto es debido a la estricta dependencia de la actividad de la nitrogenasa 
a la luz (Meyer et al., 1978). Özgür et al. (2010) observaron que la producción de hidrógeno disminuyó $50 \%$ debido las fluctuaciones diarias de temperatura (entre 15 y $40{ }^{\circ} \mathrm{C}$ ) y cuando los tratamientos fueron adicionalmente expuestos a ciclos luz-oscuridad, la producción de hidrógeno disminuyó 80\%. En este trabajo, la producción de hidrógeno bajo condiciones ambientales fue cerca de la mitad de lo que se obtuvo bajo condiciones controladas a pesar de las fluctuaciones ambientales.

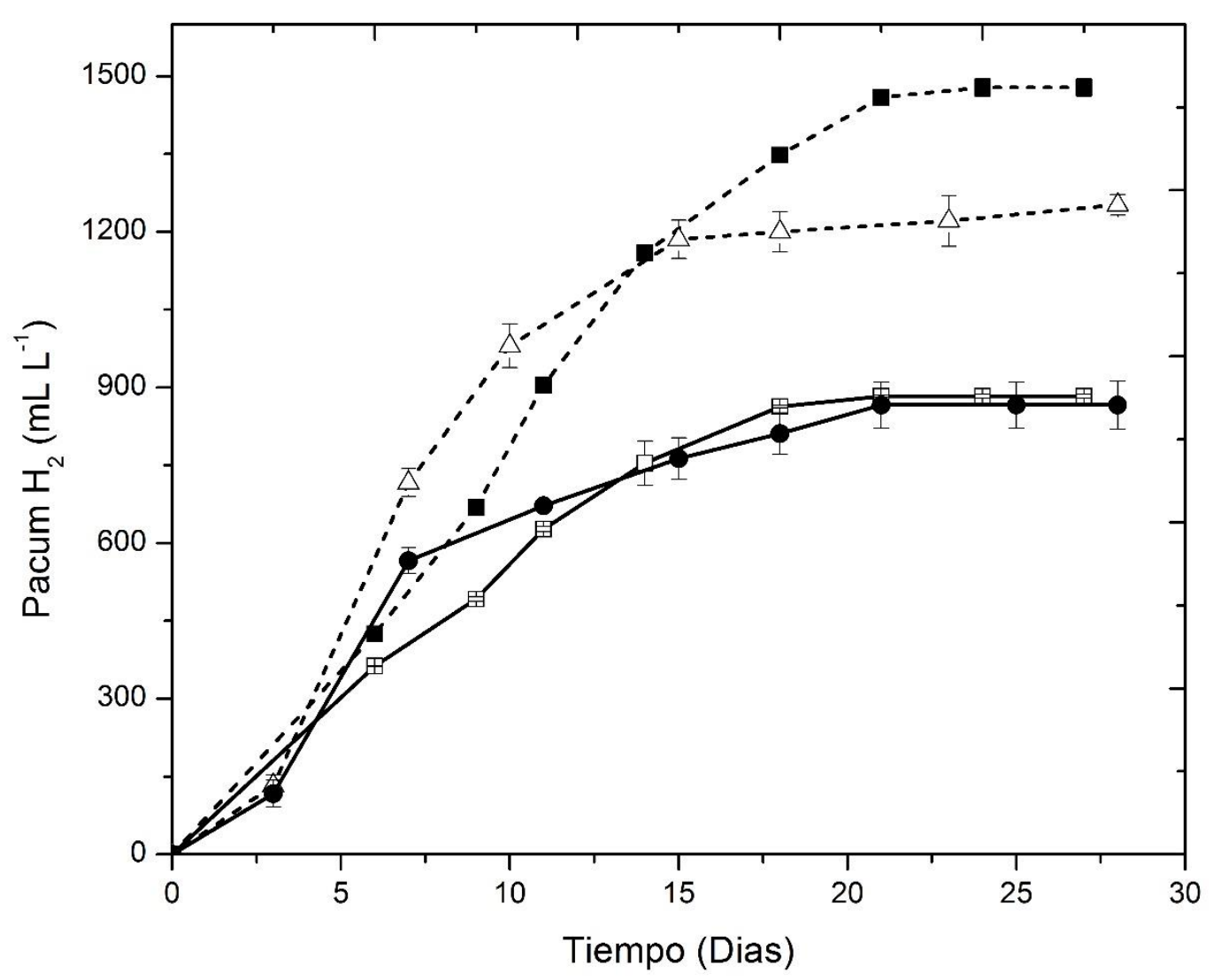

Figura 2.3. Cinéticas de Pacum $\mathrm{H}_{2}$ para el cultivo IZT y $R$. capsulatus operados con presión reducida y $250 \mathrm{mg} \mathrm{NaHCO} \mathrm{L}^{-1}$. Los primeros 5 días todos los tratamientos se mantuvieron bajo condiciones controladas, $30{ }^{\circ} \mathrm{C}$ y $3 \mathrm{kLux}$. IZT-condiciones controladas ( $\left.\mathbf{\square}\right)$, IZT-condiciones ambientales ( $\left.\square\right), R$. capsulatus -condiciones controladas $(\Delta), R$. capsulatus -condiciones ambientales $(\bullet)$. Algunas barras de error no son visibles debido a que las desviaciones estándar son muy pequeñas. 


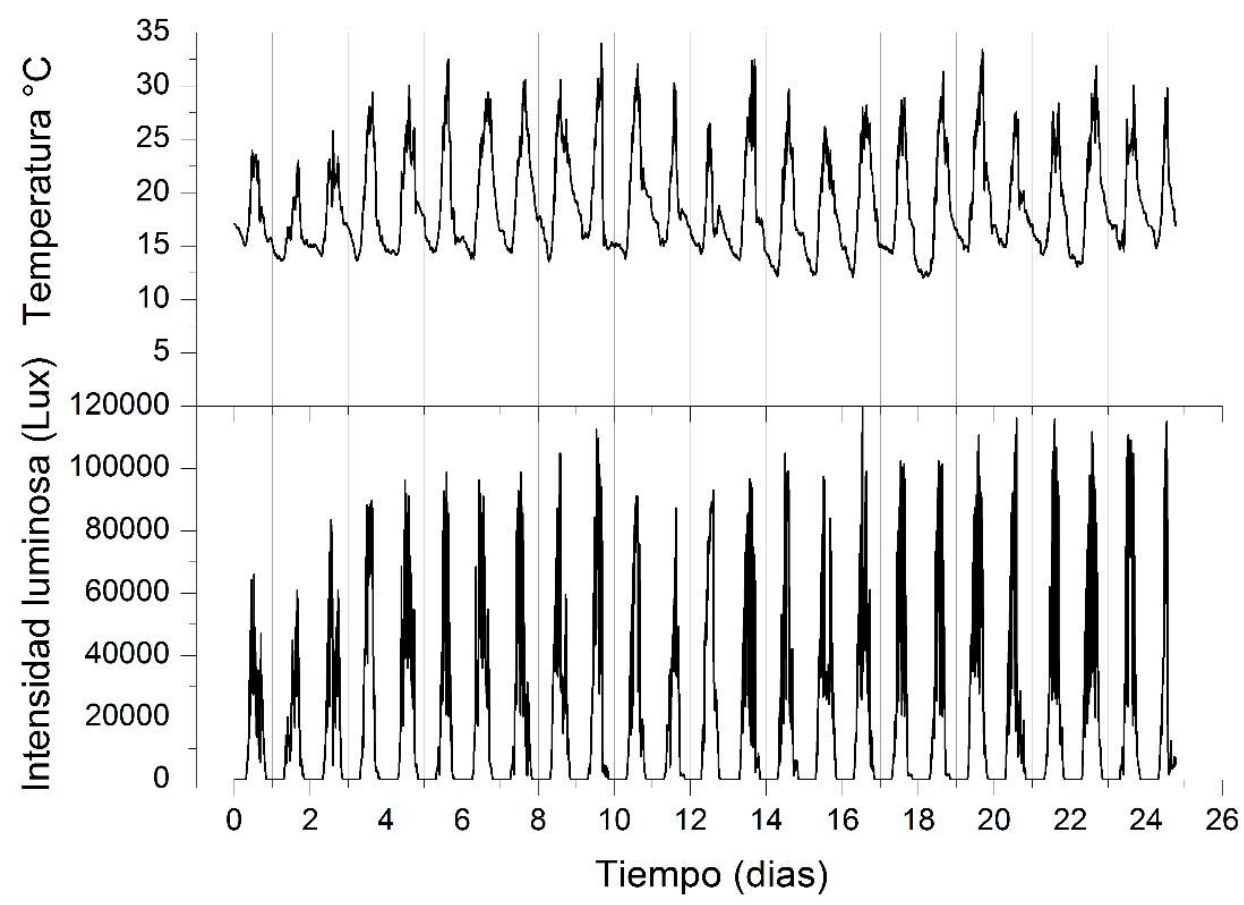

Figura 2.4. Fluctuaciones de intensidad luminosa (Lux) y temperatura registradas durante la producción de hidrógeno en condiciones ambientales (Junio-Julio, 2012, Ciudad de México D.F.).

\subsubsection{Acumulación de PHB}

El análisis de varianza para la variable de respuesta acumulación de PHB mostrado en la tabla 2.4 indica que el tipo de cultivo $(p<0.0009)$, método de purgado del headspace $(p<0.0056)$ y las condiciones de incubación $(p<0.0142)$ tuvieron efecto significativo sobre la producción de PHB. La tabla 2.3 muestra que $R$. capsulatus acumuló, en promedio, más PHB que el cultivo IZT, pero en ambos casos la producción de PHB e hidrógeno fueron negativamente correlacionados mostrando que los productos compiten por la energía disponible. 
La capacidad para acumular PHB por las BPNS depende del tipo de sustrato, $\mathrm{pH}$, condiciones de incubación y de la cepa de BPNS y de sus rutas metabólicas, como se mencionó anteriormente.

Con respecto a la relación entre tipo de método para purgar el headspace y la producción de PHB, el purgado con Ar indujo una alta producción de $\mathrm{PHB}$, seguido por presión reducida y purgado $\mathrm{con}^{\mathrm{CO}} \mathrm{CO}_{2}$ en tercer lugar. La acumulación de PHB ha sido relacionada en forma directa con el pH, y el tipo de headspace en forma indirecta. Se sabe que cuando el pH es alcalino o ligeramente alcalino la producción de PHB es favorecida. Khatipov et al. (1998) reportaron que el aumento de pH de 6.8 a 7.5 indujo una reducción en la producción de $\mathrm{H}_{2}$ pero la producción de PHB se triplicó. En este trabajo, el $\mathrm{CO}_{2}$ en el headspace promovió la acidificación del medio a través de su disolución como ácido carbónico, por lo tanto el pH descendió a 6.1-6.6. Por otro lado, la aplicación de vacío tuvo el efecto opuesto por la remoción del $\mathrm{CO}_{2}$ producido durante la fermentación manteniendo un $\mathrm{pH}$ neutro 6.97.1. En los tratamientos purgados con $\mathrm{Ar}$, donde el pH final estuvo en el rango de 7.5-7.8, resultó con alta acumulación de PHB. En esos tratamientos, el Ar no influyó en el pH y por lo tanto el pH incremento cuando la capacidad del buffer de fosfatos se agotó.

La acumulación de PHB por $R$. capsulatus fue significativamente más baja en condiciones controladas (70 mg PHB g-1 peso seco, en promedio) que en condiciones ambientales a alta irradiación solar (190 $70 \mathrm{mg} \mathrm{PHB} \mathrm{g}^{-1}$ peso seco) (ver tabla 2.3). Las BPNS pueden acumular más PHB bajo alta irradiación luminosa (Carlozzi \& Sacchi, 2001). Sin embargo, el cultivo IZT mostró baja variación en la acumulación de PHB (68 y $52 \mathrm{mg} \mathrm{PHB} \mathrm{g}^{-1}$ peso seco) bajo condiciones controladas y ambientales, respectivamente).

Los resultados indican que el cultivo IZT intrínsecamente tiene baja capacidad para acumular PHB, por lo tanto, a pesar del pH alcalino en los tratamientos purgados con $\mathrm{Ar}$ o las fluctuaciones de temperatura y la alta irradiación que inducen la producción de PHB, el cultivo IZT no acumuló grandes cantidades de PHB. En contraste, $R$. capsulatus teniendo la capacidad para acumular PHB, fue 
significativamente afectada por las condiciones de incubación. Se puede inferir que en el cultivo IZT puede haber especies, como R. palustris, que tiene baja capacidad para acumular PHB.

La tabla 2.3 muestra que $R$. capsulatus bajo una atmósfera de $\mathrm{Ar}$ con $250 \mathrm{mg} \mathrm{L}^{-1}$ de $\mathrm{NaHCO}_{3}$ alcanza $414 \pm \mathrm{mg} \mathrm{PHB} \mathrm{g}^{-1}$ peso seco lo cual corresponde a $29 \%$ de PHB en peso seco referido al contenido de proteína, el cual es considerado como el $40 \%$ de la biomasa activa. Entre el 30 y $50 \%$ del costo de producción de PHB es el costo de la materia prima (lenczac et al., 2013), esto sugiere que el uso de DFE como sustrato y el cultivo bajo condiciones ambientales podrían reducir considerablemente el costo de producción del PHB por R. capsulatus.

\subsubsection{Remoción de DQO}

El análisis de varianza para la variable de respuesta remoción de DQO se muestra en la tabla 2.4, ésta exhibe que todos los factores, tipo de cultivo, método de purgado del headspace, condiciones de incubación (todos con $p<0.0001)$ y concentración de bicarbonato $(p=0.0130)$ tienen efecto significativo sobre la remoción de DQO. El cultivo IZT mostró alta capacidad para la remover DQO y los tratamientos con la más alta producción de hidrógeno corresponden a los que presentaron alta remoción de DQO (ver tabla 2.3). En tratamientos con el cultivo IZT bajo condiciones controladas, presión reducida y $250 \mathrm{mg} \mathrm{L}^{-1}$ de $\mathrm{NaHCO}_{3}$, los $\mathrm{AGV}$ y otros componentes del DFE fueron consumidos en el proceso hasta alcanzar $89 \%$ de la remoción de DQO; bajo condiciones ambientales, el cultivo IZT alcanzó remociones de DQO del $80 \%$ (ver tabla 2.3). Con respecto a $R$. capsulatus, los tratamientos a presión reducida y $250 \mathrm{mg} \mathrm{L}^{-1}$ de $\mathrm{NaHCO}_{3}$ mostraron una remoción de $\mathrm{DQO}$ del $65 \%$ y $68 \%$ para los tratamientos en condiciones controladas y ambientales, respectivamente. Estos resultados sugieren que las BPNS, obtenidas de fuentes naturales o aguas residuales, podrían tener alta capacidad para remover DQO y producir hidrógeno, representando una excelente alternativa para el tratamiento de residuos orgánicos. 
Los valores más altos de remoción de DQO y producción de hidrógeno fueron obtenidos en experimentos con presión reducida (ver tabla 2.3). Esto puede relacionarse con el pH neutro (entre 6.9-7.1) lo cual también fomentó una alta concentración de biomasa ( $0.25 \mathrm{~g}$ proteína $\mathrm{L}^{-1}$ en promedio) comparada con la obtenida en los tratamientos con Argón $0 \mathrm{CO}_{2}(0.16$ y $0.18 \mathrm{~g}$ proteína L-1, respectivamente). Un alto contenido de biomasa también promovió una mayor remoción de DQO. En experimentos con $\mathrm{CO}_{2}$ para el purgado del headspace, el pH fue menor (6.1- 6.6) lo que afectó el crecimiento de la biomasa, la producción de hidrógeno y remoción de DQO.

La tabla 2.5 muestra la producción de hidrógeno y remoción de DQO por foto-fermentación en lote reportada por diferentes autores que emplean efluentes de fermentación oscura como sustrato, bajo condiciones de incubación controladas y condiciones estériles. Como puede verse la remoción de DQO obtenida en este trabajo está por arriba de lo reportado por Eroglu et al. (Eroglu et al., 2006; Eroglu et al., 2011), Zhu et al. (1999), Seifert et al. (2010) y otros autores quienes emplearon cultivos puros de BPNS obtenidos de colecciones microbianas; y cerca a los obtenidos por Tao et al. (2008) quienes emplearon una cepa de BPNS aislada de aguas residuales. Aunque el acetato, butirato y carbohidratos pueden ser más recalcitrantes que el succinato, lactato o malato para las BPNS productoras de hidrogeno, en este trabajo $18 \mathrm{~L} \mathrm{H}$ fueron obtenidos por litro de DFE de residuos de frutas y verduras con alta concentración de ácido butírico y otros compuestos complejos representando $55 \mathrm{~g}$ de DQO en total. Tao et al. (2008) obtuvieron $25 \mathrm{~L} \mathrm{H}_{2} \mathrm{~L}^{-1}$ de un agua residual rica en succinato, siendo el succinato un sustrato fácilmente metabolizado por las BPNS, sin embargo cuando ellos emplean un DFE de residuos de cocina con $7.7 \mathrm{~g} \mathrm{~L}^{-1}$ y $3.4 \mathrm{~g} \mathrm{~L}^{-1}$ de ácido acético y butírico, respectivamente, la producción de hidrógeno disminuyó considerablemente a $9 \mathrm{~L} \mathrm{H}_{2} \mathrm{~L}^{-1}$ (ver tabla 2.5). Sin embargo en este trabajo la DQO inicial fue más baja que la empleada por Tao et al. (2008). Cuando se probó una DQO inicial de 9 y $13.6 \mathrm{~g} \mathrm{~L}^{-1}$ no hubo producción de hidrógeno, debido al incremento 
significativo de la concentración de biomasa (datos en apéndice 1) por el alto contenido de nitrógeno en el DFE usado como sustrato ( ver tabla 2.2), interfiriendo con la distribución de la luz en el cultivo. La concentración inicial de DQO o factor de dilución depende del tipo y composición del DFE o agua residual empleada, por ejemplo, cuando Eroglu et al. (2004) usaron una DQO inicial de $1.1 \mathrm{~g} \mathrm{~L}^{-1}$ (implicando diluir 50 veces el agua residual de aceitunas) ellos obtuvieron $13.9 \mathrm{~L} \mathrm{H}_{2} \mathrm{~L}^{-1}$, pero cuando emplearon una DQO inicial de $3.3 \mathrm{~g} \mathrm{~L}^{-1}$ no hubo producción de hidrógeno. La razón pudo ser la presencia de altas cantidades de sustancias inhibitorias y el color oscuro del agua residual de aceituna. Una vía para minimizar el uso de agua para diluir podría ser la reutilización del efluente gastado de la foto-fermentación en un nuevo ciclo de producción de hidrógeno.

En la tabla 2.5, se puede ver que los rendimientos de $\mathrm{H}_{2}(\%)$ basados en el consumo de AGVs obtenidos en este estudio son más altos que los reportados por Afsar et al. (2011), Eroglu et al. (2011) y, Azbar y Dokgoz (2010) y similares a los obtenidos por Tao et al. (2008) y Yang et al. (2010). Adicionalmente, fue posible llevar a cabo el proceso en condiciones no estériles, representando una ventaja operacional y económica a la hora de escalar el proceso. 
Tabla 2.5. Producción de $\mathrm{H}_{2}$ y remoción de DQO por BPNS empleando como sustrato aguas residuales y DFE.

\begin{tabular}{|c|c|c|c|c|c|c|c|}
\hline Organismo & Sustrato & $\begin{array}{c}\text { DQODFE } \\
\text { Original } \\
\text { (gL-1) }\end{array}$ & $\begin{array}{l}\text { DQO } \\
\text { Inicialimentada }\left(\mathrm{gL}^{-1}\right)\end{array}$ & $\begin{array}{c}\text { Remoción de } \\
\text { DQO (\%) }\end{array}$ & $\begin{array}{c}\text { Production } \\
\text { de } \mathrm{H}_{2} \\
\left(\mathrm{~L} \mathrm{LDFE}^{-1}\right)\end{array}$ & $\begin{array}{c}\text { Rendimiento } \\
\mathrm{H}_{2} \mathrm{~b}(\%)\end{array}$ & Ref. \\
\hline $\begin{array}{c}\text { R.sphaeroides } \\
\text { zx-5 }\end{array}$ & Succinato ww & 40.2 & 8.0 & 88 & 25 & $57 c$ & [3] \\
\hline $\begin{array}{c}\text { R.sphaeroides } \\
\text { zx-5 }\end{array}$ & $\begin{array}{l}\text { DFE de } \\
\text { residuos de } \\
\text { comida }\end{array}$ & 18.5 & 9.7 & 80 & 9 & $50^{c}$ & [3] \\
\hline $\begin{array}{l}\text { R.sphaeroides } \\
\text { O.U.001 }\end{array}$ & Aceituna ww & 55.0 & 1.1 & 35 & 13.9 & NR & [41] \\
\hline $\begin{array}{c}\text { R.sphaeroides } \\
\text { RV }\end{array}$ & Tofu ww & 27.4 & 27.4 & 41 & 1.9 & $14.7^{\mathrm{d}}$ & [39] \\
\hline $\begin{array}{l}\text { R.sphaeroides } \\
\text { O.U.00 }\end{array}$ & Aceituna ww & 42.0 & 21.0 & 52 & 2.0 & NR & [37] \\
\hline $\begin{array}{l}\text { R. sphaeroides } \\
\text { O.U. } 001\end{array}$ & Lacteos ww & $\begin{array}{l}46.3 \\
46.3\end{array}$ & $\begin{array}{l}18.5 \\
2.0\end{array}$ & $\begin{array}{l}23 \\
39\end{array}$ & $\begin{array}{c}8.6 \\
11.3\end{array}$ & NR & {$[40]$} \\
\hline $\begin{array}{l}\text { R. palustris } \\
\text { (DSM 127) }\end{array}$ & $\begin{array}{l}\text { DFE de suero } \\
\text { de queso }\end{array}$ & 28.0 & 5.6 & NR & $6.9 \mathrm{c}$ & $30^{c}$ & [7] \\
\hline \multirow{2}{*}{$\begin{array}{c}\text { R.sphaeroides } \\
0 . U .001\end{array}$} & \multirow{2}{*}{$\begin{array}{c}\text { Aceituna ww } \\
\text { Aceituna ww + } \\
\mathrm{Fe}+\mathrm{Mo}\end{array}$} & 55.0 & 1.1 & 30 & 5.6 & $19^{d}$ & \multirow{2}{*}{ [38] } \\
\hline & & 55.0 & 1.1 & 48 & 17.4 & $60^{d}$ & \\
\hline R. capsulatus & $\begin{array}{l}\text { DFE de } \\
\text { cáscara de } \\
\text { papa }\end{array}$ & & $0.8^{\mathrm{a}}$ & NR & $8.4 \mathrm{c}$ & 24 & [6] \\
\hline R.sphaeroides & $\begin{array}{l}\text { DFE de olote } \\
\text { de maíz }\end{array}$ & NR & $\begin{array}{c}32 \mathrm{mmol} \\
\text { acetat0, } 26 \\
\text { butirato y } 3 \\
\text { propionato }\end{array}$ & 90 & 6.2 & 51 & [5] \\
\hline $\begin{array}{l}\text { R. capsulatus } \\
\text { DSM1710 }\end{array}$ & DFE de melaza & $\begin{array}{c}86 \mathrm{mmol} \\
\text { acetato, } 69 \\
\text { lactato y } 3 \\
\text { sucrosa }\end{array}$ & $\mathrm{N} R$ & NR & $225 \mathrm{mmol}$ & 26 & [8] \\
\hline $\begin{array}{l}\text { R. capsulatus } \\
\text { DSM1710 }\end{array}$ & $\begin{array}{c}\text { DFE } \\
\text { hidrolizado de } \\
\text { paja de cebada }\end{array}$ & 16.0 & 5.3 & NR & $165 \mathrm{mmol}$ & 32 & [9] \\
\hline IZT consortium & $\begin{array}{l}\text { DFE de } \\
\text { residuos de } \\
\text { frutas y } \\
\text { verduras }\end{array}$ & DQO ${ }_{\text {Total }} 55.24$ & 4.6 & $\begin{array}{c}89 \\
\text { laboratorio } \\
80 \text { ambiente }\end{array}$ & $\begin{array}{c}18 \\
\text { laboratorio } \\
10.8 \\
\text { ambiente }\end{array}$ & $\begin{array}{l}48 \\
28\end{array}$ & $\begin{array}{l}\text { Este } \\
\text { trabajo }\end{array}$ \\
\hline
\end{tabular}

NR: no reportado, WW: agua residual, a moles de carbono, b Rendimiento de $\mathrm{H}_{2}$ calculado en base a los AGVs consumidos, ${ }^{\mathrm{c}}$

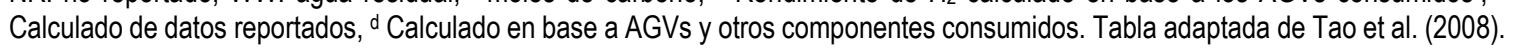




\subsection{Conclusiones.}

En este capítulo se demostró la factibilidad de la producción de hidrógeno por foto-fermentación bajo presión reducida y condiciones de incubación controladas y ambientales, por un cultivo enriquecido de BPNS usando un efluente de fermentación oscura como sustrato. La producción de hidrógeno por el cultivo fotoheterótrofo IZT fue comparable con el cultivo especializado productor de hidrógeno $R$. capsulatus. Los resultados sugieren que el purgado con Argón puede ser reemplazado con presión reducida, lo cual puede simplificar la purificación del hidrógeno. Además en este trabajo, la producción de hidrógeno fue mejorada con la adición de bicarbonato al DFE.

El cultivo IZT alcanzó mejores remociones de DQO comparado con $R$. capsulatus y otras cepas reportadas en literatura, lo que lo hace un buen candidato para el tratamiento de residuos (DFE). Ambos cultivos acumularon PHB, un compuesto de valor agregado que podría ser recuperado y contribuir a abatir los costos de producción de hidrógeno por foto-fermentación.

La producción de hidrógeno bajo condiciones ambientales fue aprox. $40 \%$ menor a la obtenida en condiciones controladas, lo cual no es despreciable y podría proveer un ahorro de energía por el uso de iluminación natural ayudando a integrar la producción de hidrógeno por foto-fermentación a los sistemas de tratamiento de residuos. 


\section{CAPÍTULO 3}

EFECTO DE CICLOS LUZ - OSCURIDAD SOBRE LA PRODUCCIÓN DE HIDRÓGENO Y PHB POR UN CULTIVO FOTOHETERÓTROFO Y R. capsulatus EMPLEANDO UN EFLUENTE DE FERMENTACIÓN OSCURA COMO SUSTRATO

Los resultados de este capítulo fueron enviados a la revista International Journal of Hydrogen Energy para su publicación (ver apendice 3). A continuación se presenta una versión del manuscrito enviado. 
Efecto de ciclos luz-oscuridad sobre la producción de hidrógeno y PHB por un cultivo fotoheterótrofo y $R$. capsulatus utilizando un efluente de fermentación oscura como sustrato.

\subsection{Introducción}

Para mejorar la producción de hidrógeno por foto-fermentación se han estudiado varios factores: pH, el tipo y concentración de AGVs (Lo et al., 2011; Tao et al., 2008), tasas de alimentación (Tawfik et al., 2014), la adición de nutrientes tales como vitaminas y minerales (Eroglu et al., 2011; Mohan et al., 2008), temperatura e iluminación (Androga et al., 2014; Argun \& Kargi, 2010), entre otros. La síntesis y actividad de la enzima nitrogenasa son fuertemente dependientes de la luz (Jouanneau et al., 1985; Meyer et al., 1978), por lo tanto, condiciones tales como la intensidad luminosa, la longitud de onda y el régimen de iluminación son críticos para la foto-fermentación. Se ha observado que la producción de hidrógeno se favorece a una intensidad luminosa de 3000 - 5000 lux y 590 nm (Argun \& Kargi 2010; Liao et al., 2010), sin embargo, en el caso del protocolo de iluminación no hay algo concluyente. La producción de hidrógeno por BPNS bajo condiciones de oscuridad es muy baja o nula (Uyar et al., 2007). Algunos autores han sugerido que bajo ciclos de luz-oscuridad se pueden obtener rendimientos aceptables, como reportaron Koku et al. (2003) con ciclos de $14 \mathrm{~h}$ luz/10 $\mathrm{h}$ oscuridad cuando emplearon Rhodobacter sphaeroides 0.U. 001 como inóculo, y Wakayama et al. (2000) con ciclos de 30 min luz/30 min oscuridad usando el cultivo Rhodobacter sphaeroides SV. En contraste, otros autores han reportado que la producción de hidrógeno bajo ciclos de luz-oscuridad es más baja que en iluminación continua (Argun et al., 2010; Li et al., 2011).

Otro factor que se ve afectado por los ciclos luz-oscuridad es la acumulación de PHB. Sharma y Mallik (2005) y Fradinho et al. (2013) observaron que la acumulación de PHB en cultivos de cianobacterias depende del ciclo de luz-oscuridad usado. Sin embargo, información acerca del efecto de los ciclos luz-oscuridad sobre la producción de PHB es escasa para BPNS. 
Debido a los resultados contradictorios con respecto al efecto de los ciclos de luz-oscuridad sobre la producción de hidrógeno por cultivos puros de BPNS, el propósito de este trabajo fue estudiar el efecto de la utilización de ciclos luz-oscuridad relativamente cortos sobre la producción de hidrógeno y PHB, en el proceso de foto-fermentación llevada a cabo por el cultivo puro $R$. capsulatus y el cultivo mixto enriquecido IZT reportado en el capítulo 2, el cual demostró buena capacidad para producir hidrógeno y remover DQO usando un efluente de la fermentación oscura como sustrato.

\subsection{Materiales y métodos}

\subsubsection{Inóculo}

Como inóculo se emplearon el cultivo IZT y Rhodobacter capsulatus ATCC 17015, los cuales fueron preservados y propagados conforme lo descrito en el capítulo 2.

\subsubsection{Sustrato}

El sustrato utilizado fue el efluente de la fermentación oscura de frutas y vegetales cuya composición detallada se reporta en la tabla 2.2 del capítulo 2 .

\subsubsection{Diseño experimental}

Se probó un diseño factorial completo usando dos inóculos: el cultivo IZT y la cepa Rhodobacter capsulatus ATCC 17015; y tres regímenes de iluminación artificial: ciclos luz-oscuridad de 15:15, 30:30 y 60:60 minutos. Como experimento control se colocó un tratamiento bajo iluminación artificial continua. Adicionalmente, otros controles se montaron solo con DFE y sin inóculo fotoheterotrófo para corroborar que la producción de hidrógeno sólo proviene de los cultivos de BPNS y no de los microorganismo que pudieran estar presentes en el DFE. 
La variables de respuesta fueron: producción acumulada de hidrógeno $\left(P a c u m H_{2}\right)$ en $\mathrm{mL} \mathrm{H}_{2} \mathrm{~L}^{-1}$ de DFE diluido, remoción de AGVs (\%), remoción de DQO (\%), biomasa (mg proteína L-1), y acumulación de PHB (mg PHB gdw $\left.w^{-1}\right)$.

\subsubsection{Producción de hidrógeno en lote bajo ciclos luz-oscuridad}

Los experimentos se llevaron a cabo en botellas serológicas de $120 \mathrm{~mL}$ con $69 \mathrm{~mL}$ de agua de grifo y $7 \mathrm{~mL}$ del DFE no esterilizado previamente centrifugado a $4000 \mathrm{rpm}$ por $10 \mathrm{~min}$. El efluente así diluido fue complementado con $250 \mathrm{mg}$ de $\mathrm{NaHCO}_{3}$ y el pH fue ajustado a 6.8. Después de esto, se añadieron $4.5 \mathrm{~mL}$ de una solución amortiguadora de fosfato al $420 \mathrm{mM}$. Las botellas se sellaron y desgasificaron por medio vacío como se describió en el capítulo 2. Todas las botellas fueron inoculadas con $5 \mathrm{~mL}$ (equivalente a $0.001 \mathrm{gL}^{-1}$ de proteína) del medio de cultivo apropiado y se incubaron a $32 \pm 3^{\circ} \mathrm{C}$ a una intensidad luminosa de 3000 Lux bajo el ciclo luz-oscuridad artificial correspondiente.

Cada ensayo fue realizado por duplicado. Cada 3 días el espacio gaseoso fue muestreado y posteriormente purgado aplicando vacío para reducir la presión parcial de hidrógeno.

\subsubsection{Métodos analíticos}

El contenido de $\mathrm{H}_{2}$ en los biorreactores, la concentración de la biomasa, la acumulación de PHB, y la remoción de AGVs y DQO fueron cuantificados conforme se describe en el capítulo 2.

\subsection{Resultados y discusión}

\subsubsection{Producción de hidrógeno}

En la Tabla 1 se muestran los valores de las variables de respuesta de cada experimento en lote. Los biorreactores conteniendo los cultivos de IZT y de $R$. capsulatus fueron expuestos a los mismos 
regímenes de iluminación simultáneamente y en los mismos periodos de tiempo. De la Tabla 1, se puede observar en primera instancia que la PacumH $\mathrm{P}_{2}$ para el cultivo IZT fue mayor en casi un $50 \%$ a la del cultivo $R$. capsulatus.

Tabla 3.1. Valores promedio* obtenidos para las variables de respuesta analizadas en los diferentes tratamientos empleando los cultivos IZT y R. capsulatus (R. caps) bajo iluminación continua (cont) y ciclos de luz-oscuridad (60, 30, $15 \mathrm{~min})$.

\begin{tabular}{|c|c|c|c|c|c|}
\hline Tratamiento & $\begin{array}{l}\text { PacumH } \\
\left(m L H_{2} L^{-1}\right)\end{array}$ & $\begin{array}{c}\text { Remoción } \\
\text { DQO } \\
(\%)\end{array}$ & $\begin{array}{c}\text { PHB } \\
\text { acumulado } \\
\left(\mathrm{mg} \mathrm{gdw}^{-1}\right)\end{array}$ & $\begin{array}{l}\text { Remoción } \\
\text { AGVs (\%) }\end{array}$ & $\begin{array}{c}\text { Biomasa }^{* *} \\
\left(\mathrm{mg} \text { proteina } \mathrm{L}^{1}\right)\end{array}$ \\
\hline IZT cont & $1290 \pm 67$ & $78 \pm 1$ & $70 \pm 3$ & $100 \pm 1$ & $216 \pm 6$ \\
\hline IZT 60 & $1254 \pm 28$ & $82 \pm 1$ & $94 \pm 13$ & $100 \pm 1$ & $194 \pm 14$ \\
\hline IZT 30 & $1340 \pm 16$ & $80 \pm 1$ & $100 \pm 5$ & $100 \pm 1$ & $186 \pm 19$ \\
\hline IZT 15 & $1165 \pm 16$ & $78 \pm 1$ & $143 \pm 10$ & $100 \pm 1$ & $184 \pm 16$ \\
\hline R. caps cont & $720 \pm 23$ & $47 \pm 1$ & $70 \pm 6$ & $60 \pm 1$ & $181 \pm 6$ \\
\hline R. caps 60 & $590 \pm 13$ & $53 \pm 2$ & $146 \pm 18$ & $74 \pm 1$ & $176 \pm 18$ \\
\hline R. caps 30 & $590 \pm 70$ & $56 \pm 2$ & $250 \pm 2$ & $78 \pm 1$ & $181 \pm 2$ \\
\hline R. caps 15 & $580 \pm 36$ & $65 \pm 1$ & $200 \pm 6$ & $83 \pm 1$ & $211 \pm 6$ \\
\hline
\end{tabular}

La Figura 3.1 muestra la cinética de $\mathrm{PacumH}_{2}$ por el cultivo IZT y $R$. capsulatus bajo iluminación continua y los ciclos luz-oscuridad de 30 minutos. La producción de hidrógeno por el cultivo IZT se mantuvo por 30 días, mientras que $R$. capsulatus no produjo más hidrógeno después de 20 días, lo que resultó en bajos rendimientos. La producción de hidrógeno fue únicamente atribuible al cultivo IZT 
y $R$. capsulatus debido a que los controles con DFE y sin inóculo fotoheterótrofo no produjeron hidrógeno.

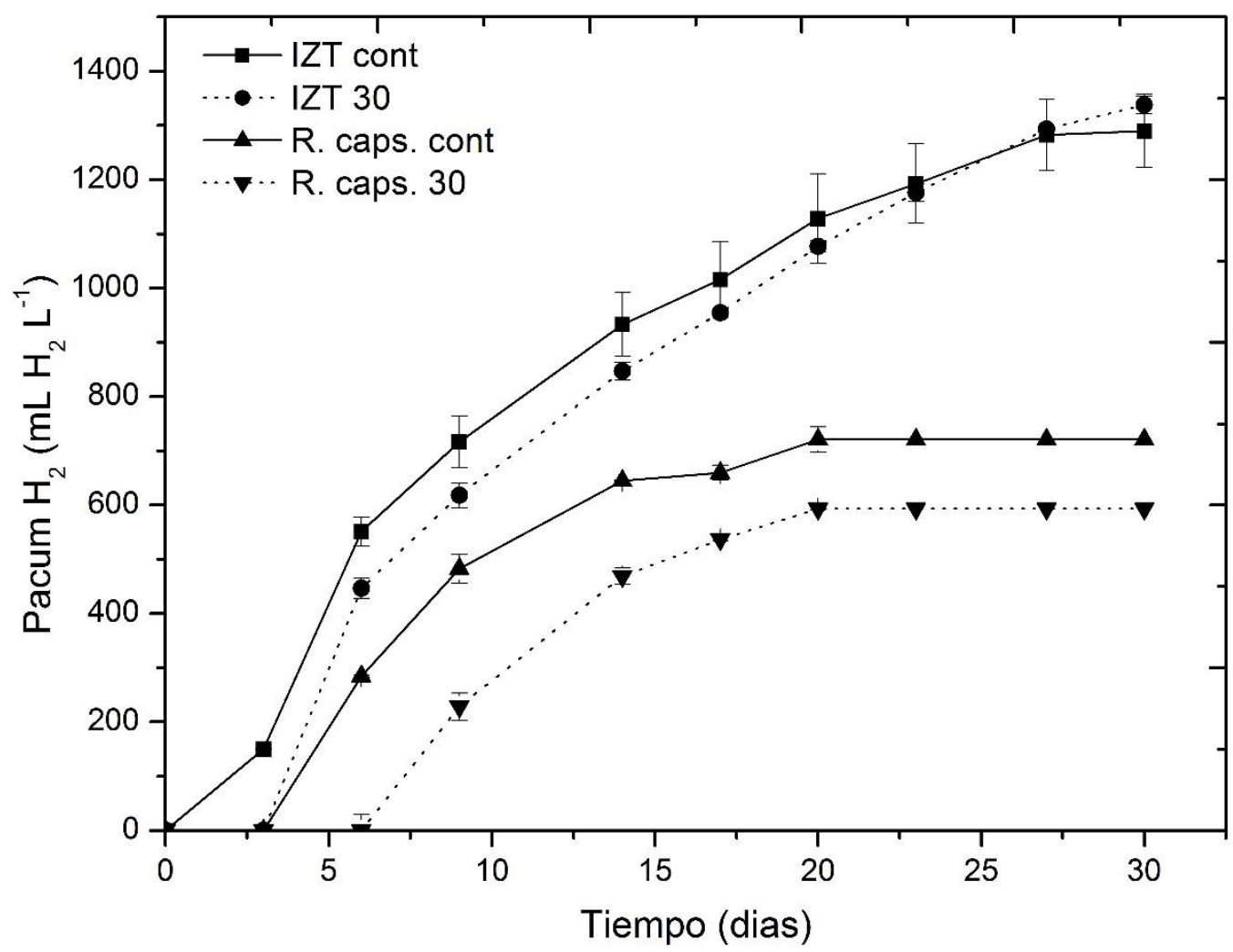

Figura 3.1. Evolución de la PacumH $\mathrm{P}_{2}$ para los cultivos IZT y $R$. capsulatus bajo iluminación continua (IZT cont y R. caps. cont) y fotoperiodos de 30 minutos.

En la figura 3.2 se puede observar que los cultivos bajo iluminación continua alcanzan una concentración máxima de biomasa al día 3. En este punto, el cultivo IZT produce hidrógeno mientras R. capsulatus empieza la producción después del día 3 (Figura 3.1). 


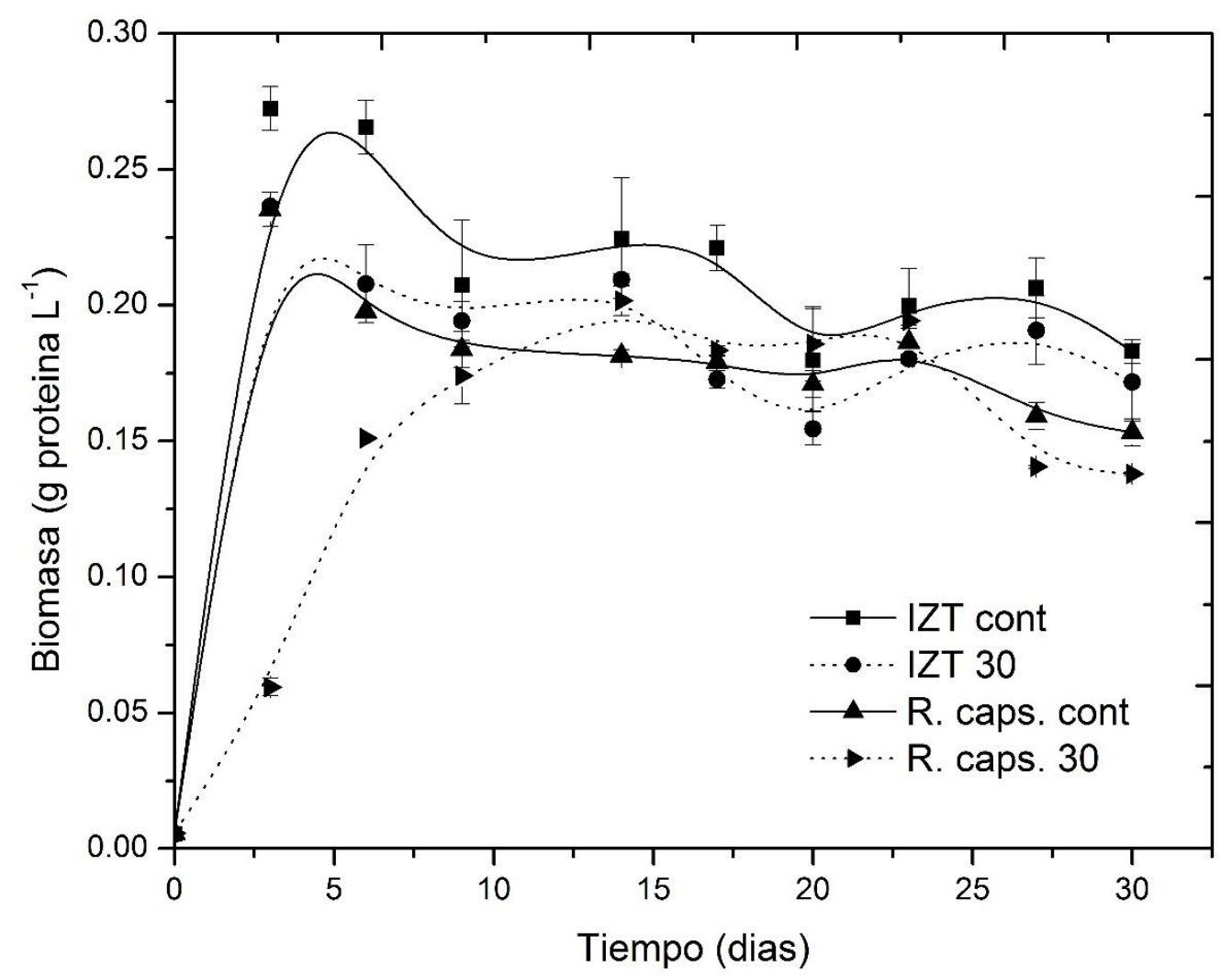

Figura 3.2. Evolución de la biomasa para los cultivos IZT y R. capsulatus (R. caps) en los tratamientos bajo iluminación continua (cont) y fotoperiodos de 30 minutos.

En los tratamientos bajo ciclos luz-oscuridad de 30 minutos, el cultivo IZT también alcanza la concentración máxima de biomasa en el día 3 y la producción de hidrógeno comienza entre el día 3 y 6. $R$. capsulatus comienzan la producción de hidrógeno hasta el día 6. Los tratamientos expuestos a ciclos luz-oscuridad de 15 y 60 minutos siguen la misma tendencia (datos no mostrados).

Algunos autores argumentan que los cultivos de BPNS incubados bajo iluminación continua obtienen suficiente ATP para la producción de biomasa e hidrógeno, mientras que con ciclos luz-oscuridad les toma más tiempo producir suficiente ATP para la producción de $\mathrm{H}_{2}$ (Li et al., 2011; Sargsyan et al., 2015; Uyar et al., 2007). Sin embargo, una vez que inició la producción de $\mathrm{H}_{2}$ bajo ciclos luz-oscuridad, el cultivo IZT alcanzó la misma PacumH $\mathrm{H}_{2}$ que los tratamientos con iluminación continua. Esto no se 
observa con $R$. capsulatus, los ciclos luz-oscuridad tuvieron efecto negativo en su eficiencia de producción de $\mathrm{H}_{2}$. La PacumH 2 para $R$. capsulatus bajo iluminación continua fue de $720 \mathrm{~mL} \mathrm{H}_{2} \mathrm{~L}^{-1}$ y bajo los ciclos luz-oscuridad de 15, 30 y 60 min se redujo a 580, 590 y $590 \mathrm{~mL} \mathrm{H}_{2} \mathrm{~L}^{-1}$, respectivamente. El descenso en la producción de $\mathrm{H}_{2}$ bajo ciclos luz-oscuridad se ha observado también en otras especies de BPNS. Así, Uyar et al. (2007) sometieron a fotoperiodos de $14 \mathrm{~h}$ luz/10 h oscuridad a cultivos de Rhodobacter sphaeroides 0.U. 001 y observaron un descenso del 20\% en la producción de $\mathrm{H}_{2}$ en comparación con lo obtenido bajo iluminación continua. Argun y Kargi (2010) reportaron un descenso de hasta $48 \%$ en la producción de $\mathrm{H}_{2}$ con ciclos de 0.5 h luz-oscuridad comparado con iluminación continua cuando emplearon Rhodobacter sphaeroides RV y ciclos de 0.5 h, 2 h, 4 h, 6 h, $12 \mathrm{~h}$.

Por otro lado, el cultivo IZT alcanzó la máxima PacumH $2\left(1340 \pm 16 \mathrm{~mL} \mathrm{H} \mathrm{L}^{-1}\right)$ con los ciclos luzoscuridad de 30 min (Tabla 3.1). En este caso, se aplicó la prueba estadística $t$ de Student a la $\mathrm{PacumH}_{2}$ de los tratamientos bajo iluminación continua y ciclos luz-oscuridad, y los resultados mostraron que no hubo diferencia significativa entre la $\mathrm{PacumH}_{2}$ de los tratamientos bajo iluminación continua y los tratamientos bajo ciclos luz-oscuridad de 60 y $30 \mathrm{~min}$, pero para el ciclo de $15 \mathrm{~min}$ se determinó su efecto negativo. Cabe mencionar que los ciclos luz-oscuridad aplicados en este trabajo se seleccionaron de acuerdo a lo reportado por Wakayama et al. (2000) quienes experimentaron con fotoperiodos de $5 \mathrm{~s}$ hasta $12 \mathrm{~h}$ utilizando Rhodobacter sphaeroides RV, obteniendo la máxima producción de $\mathrm{H}_{2}$ con ciclos de 30 min luz/30 min oscuridad.

El cultivo IZT fue previamente sometido a ciclos luz-oscuridad naturales (ver capítulo 2), observando un descenso en la producción de $\mathrm{H}_{2}$ de $1478 \mathrm{~mL} \mathrm{H}_{2} \mathrm{~L}^{-1}$, obtenido en condiciones de laboratorio e iluminación continua, hasta $860 \mathrm{~mL} \mathrm{H} \mathrm{L}^{-1}$ con ciclos de $14 \mathrm{~h}$ de luz natural/10 h oscuridad en condiciones ambientales. En este trabajo, el cultivo IZT mejoró sustancialmente la producción de $\mathrm{H}_{2}$ al ser expuesto a ciclos luz-oscuridad más cortos. A pesar de que los tratamientos bajo ciclos 
recibieron solo la mitad del tiempo luz, acumularon cantidades similares de $\mathrm{H}_{2}$ que los tratamientos bajo iluminación continua, posiblemente debido a una mejor estabilidad e incremento de actividad de la nitrogenasa bajo ciclos luz-oscuridad.

La nitrogenasa, enzima clave en la producción de $\mathrm{H}_{2}$ por las BPNS, es estrictamente dependiente de la luz puesto que el agente reductor requerido por la reacción catalizada por la nitrogenasa solo puede generarse en una reacción fotoquímica. Esta enzima no tienen actividad en la oscuridad, aún cuando energía en forma de ATP es suministrada por fosforilación oxidativa (Meyer et al., 1978). Sin embargo, es posible una mayor estabilidad en la actividad de la nitrogenasa bajo iluminación intermitente comparado con la iluminación continua. Esto fue reportado por Meyer et al. (1978) quienes incubaron Rhodopseudomonas capsulata bajo un patrón alternado de iluminación, observando que las células suspendidas del cultivo sintetizaron cantidades similares de nitrogenasa que bajo iluminación continua, y que además la actividad de la nitrogenasa se mantuvo durante periodos de tiempo más largos. Las células bajo iluminación continua mostraron actividad nitrogenasa de 80-90 nmoles de $\mathrm{C}_{2} \mathrm{H}_{4} \mathrm{~min}^{-1} \mathrm{mg} \mathrm{dw} \mathrm{L}^{-1}$ solo por $10 \mathrm{~h}$; mientras que las células bajo ciclos de luz-oscuridad, mantuvieron su actividad por $60 \mathrm{~h}$.

No hay una respuesta concluyente que explique la variación de la producción de hidrógeno con respecto al patrón de iluminación. Mientras que algunos investigadores reportan que los ciclos de luzoscuridad mejoran la producción de hidrógeno otros muestran resultados diferentes. Por ejemplo, Wakayama et al. (2000) obtuvieron $50 \%$ más hidrógeno con ciclos de 30 min comparado con iluminación continua. Koku et al. (2003) observaron un incremento del $20 \%$ en la producción de hidrógeno con fotoperiodos de $14 \mathrm{~h}$ luz/10 h oscuridad usando Rhodobacter sphaeroides 0.U. $001 \mathrm{y}$ Uyar et al. (2007) usando el mismo microorganismo y patrón de iluminación obtuvieron $20 \%$ menos hidrógeno. 
En este trabajo, con ciclos de 30 min y el cultivo IZT, se obtuvo una producción de hidrógeno similar bajo ciclos de luz-oscuridad e iluminación continua, Li et al. (2011) con ciclos de 12/12 h luz:oscuridad y Rhodobacter sphaeroides ZX-5 obtuvieron el mismo resultado.

Aparentemente, la actividad de la nitrogenasa y, por lo tanto, la producción de hidrógeno están influenciadas por la duración de los ciclos luz-oscuridad conjuntamente con otros factores tales como la especie de BPNS, el tipo de nitrogenasa y la fuente de carbono y nitrógeno (Kim et al., 2012). Diferentes especies de BPNS tienen distintos tipos de nitrogenasas: se sabe que $R$. sphaeroides tiene solo la Mo-nitrogenasa, $R$. capsulatus y $R$. rubrum tienen adicionalmente la Fe-nitrogenasa y, $R$. palustris CGA009 tienen genes que codifican para tres diferentes nitrogenasas (Mo-nitrogenasa, Vnitrogenasa y Fe- nitrogenasa). Cuando ocurre la co-expresión de estas enzimas, se puede obtener una alta producción de hidrógeno (Kars \& Gunduz, 2010). El alternar las condiciones de luz y oscuridad puede tener diversos efectos sobre los diferentes tipos de nitrogenasa y de ahí que se puedan presentar diferentes rendimientos de producción de hidrógeno dependiendo la especies de BPNS. Además, esto también puede cambiar el nivel de los pigmentos fotosintéticos, modificando el metabolismo anaeróbico bacteriano y afectando la producción de hidrógeno (Sargsyan et al., 2015).

\subsubsection{Remoción de AGVs}

El cultivo IZT alcanzó el 100\% de remoción de AGVs para el día 11 (ver Tabla 3.1) bajo iluminación continua, mientras que en el caso de los tratamientos con ciclos luz-oscuridad la remoción completa se obtuvo al día 16, aún cuando la producción de hidrógeno duró hasta el día 30. Estos resultados sugieren que la producción de hidrógeno no depende sólo de los AGVs iniciales provenientes del DFE, sino de la materia orgánica remanente presente en el DFE, la cual se cuantifica globalmente como DQO, y que también es consumida (ver sección 3.3.3). El cultivo IZT pudo generar hidrógeno a partir de la materia orgánica más recalcitrante una vez que los AGVs fácilmente degradables de los DFE se 
acabaron o a partir de AGVs adicionales que las bacterias fermentativas provenientes del efluente de la fermentación oscura no estéril pudieron haber producido de la DQO disponible. Como se hizo notar en la sección 3.3.1, las bacterias fermentativas del DFE no produjeron hidrógeno, sin embargo, algunos acetógenos, por ejemplo aquellos que pertenecen al género Clostridium, pueden convertir hexosas directamente a acetato sin producir hidrógeno (Ghimire et al., 2015).

En el caso de $R$. capsulatus, el consumo de AGVs no fue completo (ver Tabla 3.1). Bajo iluminación continua, la concentración del ácido butírico fue de 1055 ppm al principio del experimento, 150 ppm al día 9, y posteriormente no se consumió más; la concentración de ácido acético fue de 160 ppm en el primer día, 20 ppm al día 3 pero, se incrementó a 215 ppm al final del experimento (ver Figura 3.3). Comparando las Figuras 3.2 y 3.3, también es evidente que durante los primeros días, cuando los microorganismos $R$. capsulatus estuvieron en fase de crecimiento exponencial, consumieron ácido acético, pero una vez que alcanzaron la fase estacionaria, la velocidad de consumo de AGVs fue baja y el ácido acético se acumuló. Los tratamientos con ciclos de luz-oscuridad exhibieron el mismo patrón: el ácido butírico no fue completamente consumido, mientras que el ácido acético se consumió durante los primeros 5 días y posteriormente su concentración se incrementó hasta 200 ppm en promedio. Estas observaciones sugieren la actividad continua de bacterias fermentativas provenientes del DFE como se postuló arriba para el cultivo IZT. La velocidad de consumo de los AGVs por R. capsulatus fue menor que la velocidad de producción de AGVs de las bacterias fermentativas, como se puede deducir del hecho de que $R$. capsulatus empezó la producción de hidrógeno 3 días después de que lo hizo el cultivo IZT (ver Figura 1). Sin embargo, la posibilidad de que la $R$. capsulatus pudiera alternativamente llevar a cabo el metabolismo fermentativo y producir AGVs no puede descartarse, debido a la versatilidad del metabolismo de las BPNS (Koku et al., 2002). 


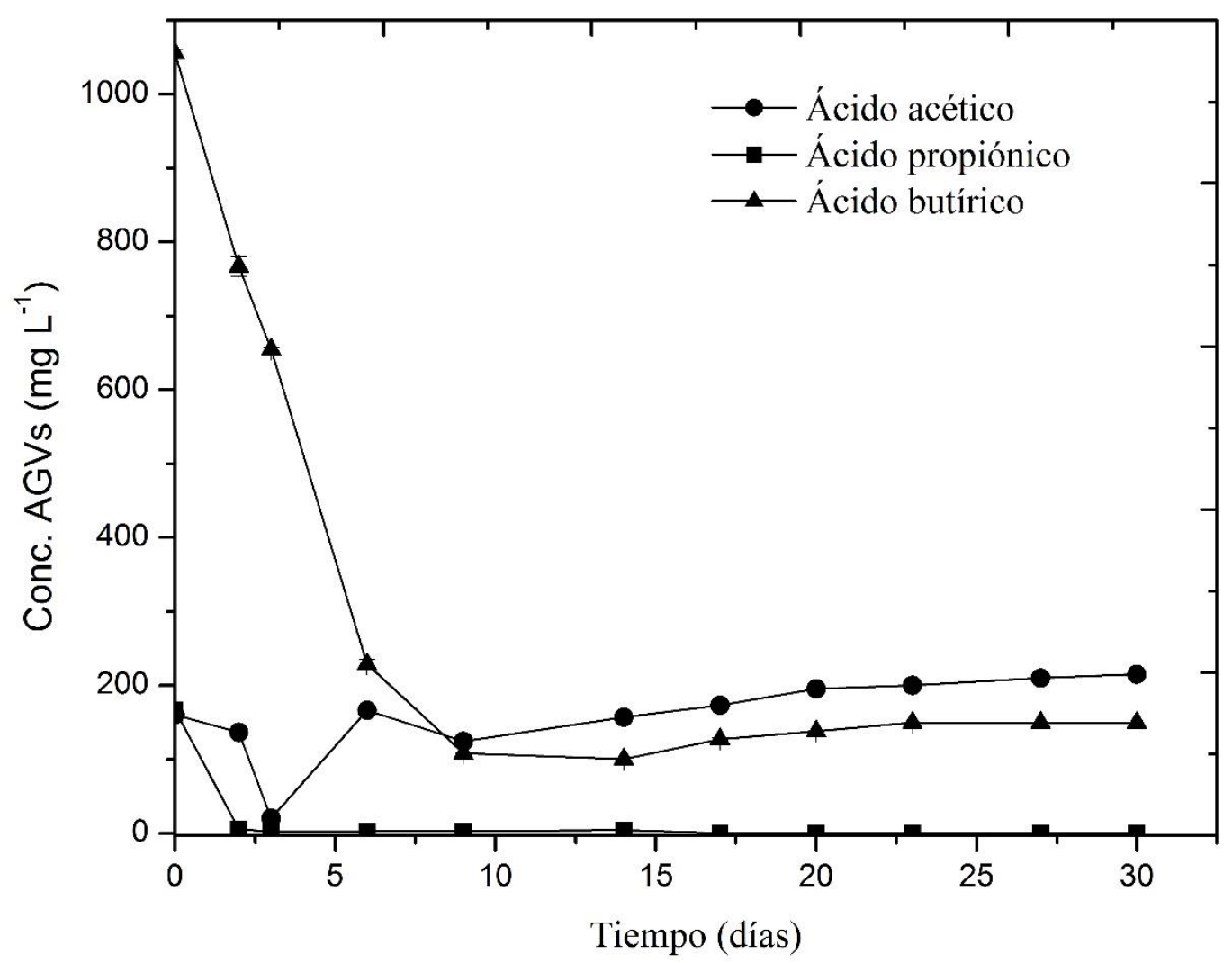

Figura 3.3. Cinética de consumo de AGVs por el cultivo R. capsulatus bajo iluminación continua.

\subsubsection{Remoción de DQO.}

La Tabla 3.1 muestra que el cultivo IZT tiene gran capacidad para remover DQO, con valores cercanos al $80 \%$ para todos los tratamientos. Se sabe que las BPNS tienen un metabolismo versátil y que pueden usar una amplia variedad de sustratos orgánicos como donadores de electrones y fuentes de carbono mientras crecen de forma fotoheterotrófica (Abo-Hashesh et al., 2013).

La remoción de DQO por la $R$. capsulatus fue menor que el cultivo IZT, además, el régimen de iluminación tuvo un efecto significativo en la remoción del DQO por la $R$. capsulatus. Como se ve en la Tabla 3.1, la remoción de DQO fue menor (47\%) bajo iluminación continua, que en los ciclos de luzoscuridad. 
Se debería esperar que la remoción de DQO fuera similar para todos los ciclos de iluminación debido a que no hubo diferencia significativa en la $\mathrm{PacumH}_{2}$, sin embargo con el ciclo más corto (15 min), se alcanzó la concentración de biomasa más alta, indicando que parte de la DQO fue utilizada para la producción de biomasa. Las BPNS también pueden consumir parte del sustrato para producir y acumular sustancias de reserva como el PHB, la cantidad dependerá de las condiciones de incubación como se discute abajo.

\subsubsection{Acumulación de PHB.}

Como se puede ver en la Tabla 3.1, se acumuló más PHB bajo ciclos de luz-oscuridad que en condiciones de iluminación continua. En general, el cultivo IZT acumuló menos PHB que el cultivo de $R$. capsulatus. Para ambos cultivos, la producción más baja de hidrógeno y la mayor acumulación de PHB se observó en los tratamientos sometidos a ciclos de 15 min luz/15 min oscuridad, lo cual sugiere que hay una desviación de protones y electrones de la producción de hidrógeno hacia la síntesis de PHB.

La Tabla 3.1 también muestra que en $R$. capsulatus, la acumulación de PHB se incrementó conforme la remoción de AGVs y DQO fue mayor y los ciclos de luz-oscuridad fueron más cortos. Estos resultados concuerdan con la hipótesis de que el sustrato fue consumido para la síntesis de PHB. La excepción puede ser el tratamiento con ciclos de 15 min luz/15 min oscuridad para el cual $R$. capsulatus tuvo la mayor remoción de DQO y AGVs pero no acumuló la mayor cantidad de PHB; sin embargo, produjo la mayor concentración de biomasa. Por lo tanto, si la materia orgánica no es dirigida a la síntesis de $\mathrm{H}_{2}$, va hacia la producción de biomasa y, bajo ciertas circunstancias, hacia la acumulación de material de reserva como el PHB.

Se sabe que cuando la actividad de la nitrogenasa es inhibida, la actividad del ciclo de los ácidos tricarboxílicos es limitada, y diversas rutas alternativas pueden ser estimuladas, incluyendo la síntesis 
de PHB (Sargsyan et al., 2015). El ácido butírico y acético pueden ser fácilmente convertidos a unidades acetil sin la formación de piruvato, facilitando la ruta de producción de PHB (Koku et al., 2002).

Sharma y Mallik (2005) observaron que la producción de PHB fue impulsada en la cianobacteria Nostoc muscorum cuando ésta fue sometida a condiciones de oscuridad por 7 días y posteriormente a incubación con luz. Fradinho et al. (2013) reportaron que un consorcio de bacterias fotosintéticas y algas acumularon $6 \%$ más PHB bajo ciclos de luz-oscuridad de $4 \mathrm{~h}$ que bajo iluminación continua. En este trabajo, el $\mathrm{H}_{2}$ y el PHB se produjeron simultáneamente; el cultivo IZT duplicó su producción de PHB y R. capsulatus la triplicó bajo ciclos de luz-oscuridad de $15 \mathrm{~min}$.

\subsection{Conclusiones}

Las condiciones de iluminación continua para los procesos de foto-fermentación es uno de los mayores problemas para su aplicación a nivel industrial; por lo tanto, estudios de los efectos de ciclos luzoscuridad sobre el metabolismo de diferentes especies de BPNS son necesarios. Este trabajo provee información sobre el efecto de ciclos luz-oscuridad sobre la producción simultánea de hidrógeno y PHB para dos cultivos de BPNS.

Los ciclos luz-oscuridad tuvieron diferente efecto sobre la producción de hidrógeno para el cultivo IZT y $R$. capsulatus. Esta última redujo en $20 \%$ la $\mathrm{PacumH}_{2}$ bajo ciclos de luz-oscuridad, mientras que el cultivo IZT mostró una producción de hidrógeno y remoción de DQO similar bajo condiciones de iluminación continua e intermitente. El uso del cultivo IZT puede contribuir significativamente a un ahorro de energía en los procesos de foto-fermentación. Curiosamente, la acumulación de PHB se relacionó directamente con el régimen de iluminación, ambos cultivos acumularon más PHB con ciclos luz-oscuridad, el cultivo IZT duplicó y $R$. capsulatus triplicó la producción de PHB. La habilidad de $R$. 
capsulatus para acumular PHB bajo ciclos de luz-oscuridad podría ser empleada para la producción de este valioso polímero biodegradable.

Por lo tanto, es posible una estrategia de producción de hidrógeno utilizando DFE en conjunto con la producción de PHB bajo ciclos de luz-oscuridad y esto puede contribuir a abatir los costos de la producción de hidrógeno. Sin embargo, debido a que los ciclos luz-oscuridad tienen diferentes efectos en las BPNS, otros estudios complementarios deberán enfocarse en la actividad de la nitrogenasa y otras rutas metabólicas que acompañan la producción de hidrógeno para un mejor entendimiento de este proceso. 


\section{CAPÍTULO 4}

\section{PRODUCCIÓN DE HIDRÓGENO EN LOTE SECUENCIAL BAJO CICLOS DE LUZ-OSCURIDAD POR UN CULTIVO FOTOHETERÓTROFO}

\subsection{Introducción}

La producción de hidrógeno por fotofermentación se ha llevado a cabo principalmente en régimen de operación en lote y recientemente se han reportado trabajos sobre la operación en lote alimentado (Boran et al. 2010; Padovani et al. 2016), lote secuencial (Pattanamanee et al., 2012), continuo y semicontinuo (Kim \& Kim, 2012; Ozmichi \& Kargi, 2010). Para que el proceso de fotofermentación pueda ser considerado a escala industrial e incluido dentro de la línea de proceso de plantas de tratamiento de aguas residuales o de residuos orgánicos, debe asegurarse una producción suficiente de hidrógeno por tiempos prolongados. Por esto se hace necesario probar e implementar la producción de hidrógeno por fotofermentación en sistemas como lote secuencial, semi-continuo o continuo. En este trabajo se ha optado por una operación por lote secuencial (SBR) debido a las ventajas que tiene frente a la operación por lotes y continuo. La operación por SBR implica la extracción periódica de una parte del contenido del reactor en alguna etapa de la fermentación y su sustitución con medio fresco. El caldo 
residual del lote anterior sirve como el inóculo para el siguiente lote. El tiempo de inactividad asociado con la preparación del inóculo y el lavado del biorreactor en la operación por lotes, se reduce al mínimo en una operación por lote secuencial (Pattanamanee et al., 2012). Las ventajas que tiene el lote secuencial frente a los sistemas en continuo son permitir un mejor control de la población microbiana debido a la operación ciclcica, alto grado de flexibilidad del proceso y desacoplamiento del tiempo de retención de sólidos del tiempo de retención hidraúlica (Arreola-Vargas et al., 2013; Buitrón \& Carvajal, 2010). Por otro lado, también es de gran interés que este proceso consuma el mínimo de energía posible y, como se vio en el capítulo anterior, una opción viable es la utilización de ciclos de luzoscuridad.

Cabe mencionar que, hasta donde se tiene conocimiento, no se ha reportado un proceso de producción de hidrógeno en lote secuencial bajo ciclos de luz-oscuridad utilizando un cultivo fotoheterotrófico.

Adicionalmente, en este capítulo se presenta la identificación de los microorganismos que conforman el cultivo IZT a través de técnicas de biología molecular.

\subsection{Materiales y métodos}

\subsubsection{Cultivo IZT}

Se utilizó como inóculo el cultivo fotoheterotrófico IZT anteriormente descrito. Éste fue preservado y propagado en un medio Pfennig modificado de acuerdo a lo descrito en el capítulo 2.

\subsubsection{Sustrato}

La composición del DFE derivado de la fermentación oscura de residuos de frutas y verduras que se usó como sustrato, para esta parte del trabajo, se describió previamente en el capítulo 2. 


\subsubsection{Estrategia experimental}

Inicialmente se llevó a cabo un ensayo de producción de hidrógeno en lote bajo iluminación continua como control para establecer la condición base del proceso de producción de $\mathrm{H}_{2}$, biomasa y remoción de AGVs y de DQO. A partir de los datos obtenidos del ensayo en lote se probaron dos experimentos en lote secuencial con tiempos de retención hidráulica (TRH) de 30 y 15 días. Una vez seleccionado el mejor THR se operó bajo dos patrones de iluminación artificial a 3000 Lux): (a) ciclos luz-oscuridad de 30 min y (b) 12 horas luz continua-12 horas con ciclos de 30 min luz-oscuridad. Inicialmente los tratamientos operaron en lote por 11-14 días y posteriormente se inició la operación en lote secuencial, para ello se retiró parte del volumen del medio líquido y se sustituyó por DFE fresco con la concentración de DQO inicial correspondiente. En ambos experimentos se estableció una frecuencia de recambio del sustrato de 7 días (duración total del ciclo del SBR) retirando $25 \%$ y $50 \%$ del contenido del reactor para un TRH de 30 y 15 días, respectivamente. Los experimentos se prepararon como se describió en el capítulo 2. Cada ensayo fue realizado por triplicado. El espacio de cabeza se purgó con vacío después de cada toma de muestra para reducir la presión parcial de hidrógeno.

Las variables de respuesta monitoreadas fueron: Pacum $\mathrm{H}_{2}$ en $\mathrm{mL} \mathrm{L}^{-1}$ de medio, remoción de AGVs (\%), remoción de DQO (\%), y la concentración de biomasa (g proteína $\mathrm{L}^{-1}$ ).

\subsubsection{Extracción de ADN y análisis del cultivo IZT por DGGE.}

Para estudiar la diversidad de microorganismos presentes del cultivo IZT se hizo un análisis por DGGE del gen $16 \mathrm{~S}$ rDNA. Se extrajeron muestras de ADN del cultivo IZT, $R$. capsulatus y $R$. palustris (estos dos últimos utilizados como controles) utilizando un kit de extracción comercial ZIMO RESEARCH ZR fungal/bacterial miniprep D6005, de acuerdo al protocolo del fabricante. 
La región V3-V5 del gen bacterial 16S rDNA se amplificó por PCR utilizando el primer forward GC338F (5'- CGC CCG CCG CGC GCG GCG GGC GGG GCG GGG GCA CGG GGG GCC TAC GGG AGG CAG CAG-3') y el primer reverse 907R (5'-CCG TCA ATT CCT TTG AGT TT-3'). Los fragmentos amplificados tuvieron 500 bps de extensión. La siguiente mezcla de reacción se utilizó para la PCR: $3 \mu \mathrm{L}$ buffer Hot stant taq 10X, $0.6 \mu \mathrm{L}$ dNTPs $10 \mathrm{mM}, 0.3 \mu \mathrm{L}$ de cada primer, $1 \mu \mathrm{L}$ de seroalbúmina de bovino al $10 \mathrm{mg} \mathrm{mL}^{-1}\left(\right.$ Promega $\left.^{\circledR}\right), 0.3 \mu \mathrm{L}$ Hot Start Taq $(5 \mathrm{U}=\mu \mathrm{l}), 30 \mathrm{ng}$ template ADN y agua tridestilada para completar $25 \mu \mathrm{L}$. La PCR se corrió en un equipo MJ Mini Gradient Thermal Cycler (BioRad, USA). El protocolo de amplificación PCR consistió de una desnaturalización inicial de 15 min a $95^{\circ} \mathrm{C}$, y 35 ciclos de $30 \mathrm{~s}$ a $94{ }^{\circ} \mathrm{C}$ (desnaturalización), 30 s a $56{ }^{\circ} \mathrm{C}$ (alineación), y 1 min a $72{ }^{\circ} \mathrm{C}$ (extensión), y una extensión final de $30 \mathrm{~s} \mathrm{a} 94^{\circ} \mathrm{C}$. La amplificación de los productos fue analizada por electroforesis en geles de agarosa $1.2 \%\left(\mathrm{p} \mathrm{v}^{-1}\right)$ y después por tinción con bromuro de etidio.

El producto de la PCR se sometió a DGGE, el cual se corrió en un equipo de electroforesis DCode (Bio-Rad) modelo 475 usando gel de poliacrilamida al 6\% con un gradiente lineal de desnaturalización de 40 a $60 \%$, donde el $100 \%$ de agente desnaturalizante fue urea al $40 \%\left(\mathrm{p} \mathrm{v}^{-1}\right)(7 \mathrm{M})$ y formaldehído al 40\% ( $\left.\mathrm{v} \mathrm{v}^{-1}\right)$. El buffer de corrida fue Tris-acetato-EDTA 1X (TAE). El gel fue sometido a la corrida de electroforesis bajo las siguientes condiciones: $75 \mathrm{~V}$, temperatura constante de $60^{\circ} \mathrm{C}$ por $15 \mathrm{~h}$. El gel se tiñó con nitrato de plata y visualizado con la ayuda de un trans-iluminador UV.

Las bandas de los geles se cortaron y amplificaron por PCR bajo las condiciones siguientes: $2.5 \mu \mathrm{L}$ Buffer Hot Stant Taq 10X, $0.5 \mu \mathrm{L}$ dNTPs $10 \mathrm{mM}, 0.25 \mu \mathrm{L}$ de cada primer (gc 338F and 907r 50 $\mu \mathrm{M}$ ), $0.83 \mu \mathrm{L}$ BSA $10 \mathrm{mg} / \mathrm{mL}, 0.25 \mu \mathrm{L}$ Hot Start Taq DNA pol (5U= $\mu \mathrm{l}), 30 \mathrm{ng}$ template DNA y agua tridestilada para completar $25 \mu \mathrm{L}$. El protocolo de amplificación del PCR fue el mencionado anteriormente.

Las secuencias amplificadas del 16S rDNA fueron secuenciadas directamente. La secuenciación se realizó en la Unidad de Síntesis y Secuenciación de ADN del Instituto de Biotecnología de la UNAM. 
Las secuencias del 16s rDNA de 500 pb se compararon con secuencias de especies contenidas en la base de datos NCBI GenBank utilizando el programa BLAST.

\subsection{Resultados}

Inicialmente y para efectos de obtener valores de referencia, se corrió un tratamiento en lote bajo iluminación continua y se hizo el seguimiento de las variables de respuesta Pacum $\mathrm{H}_{2}$, producción de biomasa, remoción de DQO, y de ácido butírico. En la figura 4.1 se puede apreciar que la producción de hidrógeno se mantiene por alrededor de 30 días, y es durante los primeros 15-17 días que se acumula la mayor cantidad de hidrógeno (aproximadamente $1170 \mathrm{~mL}$ ), posteriormente y, aunque la producción de hidrógeno continua por 15 días más, sólo se acumularon $200 \mathrm{~mL}$ adicionales. E consumo total de ácido butírico se logra a los 15 días. La mayor parte del consumo de DQO se realiza durante lor primeros 17 días y posteriormente el consumo continua aunque en menor proporción hasta alcanzar una remoción del $80 \%$ en el día 30 . 


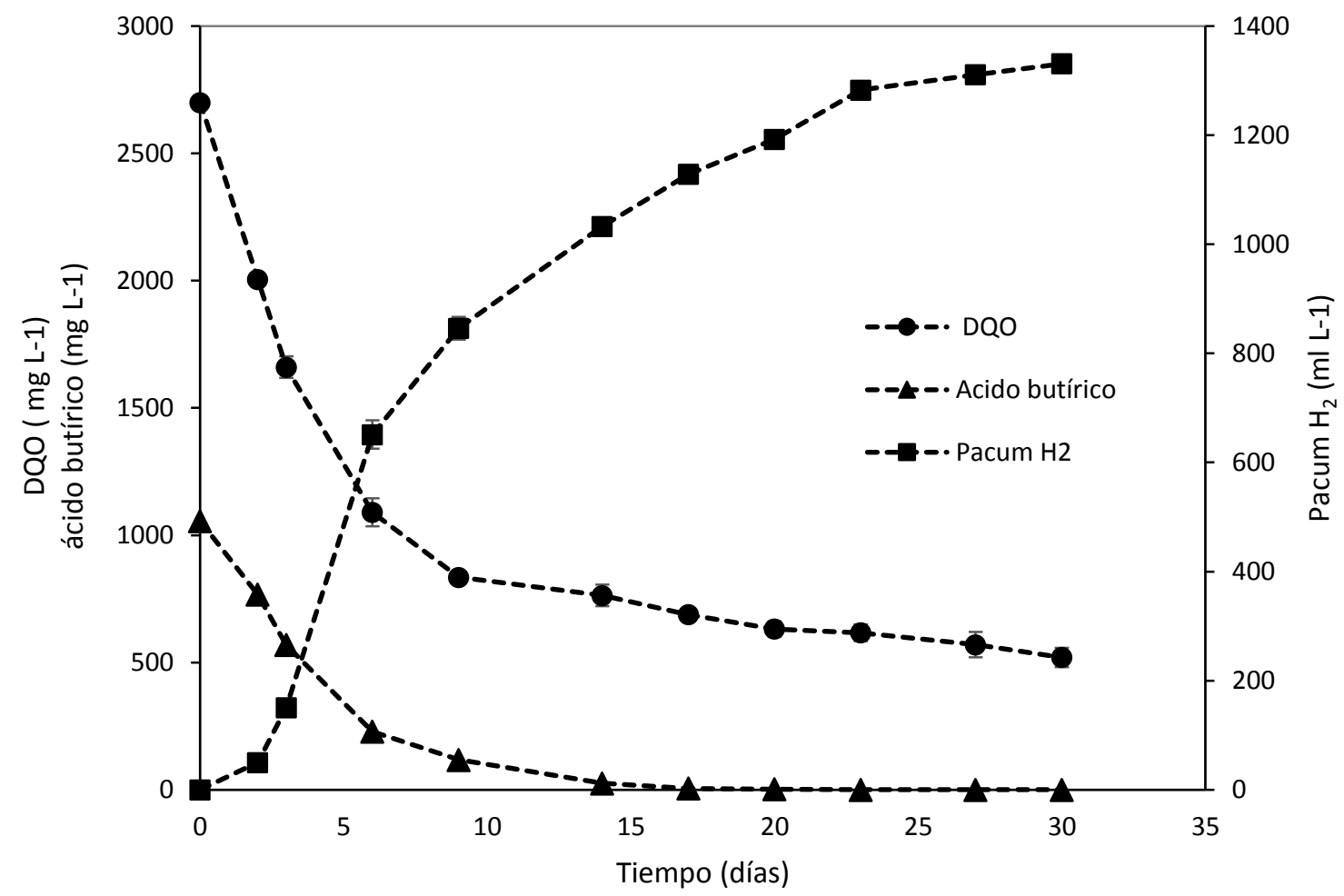

Figura 4.1. Cinéticas de Pacum $\mathrm{H}_{2}$, remoción de $\mathrm{DQO}$ y de ácido butírico por el cultivo IZT en un proceso en lote bajo iluminación continua.

La figura 4.2 muestra la concentración de biomasa durante el proceso, como se puede observar ésta alcanza una concentración máxima durante los primeros 6 días y la concentración de DQO disminuye considerablemente. Las cinéticas de este ensayo siguen las mismas tendencias que los experimentos mostrados en los capitulos 2 y 3 , el proceso es reproducible. 


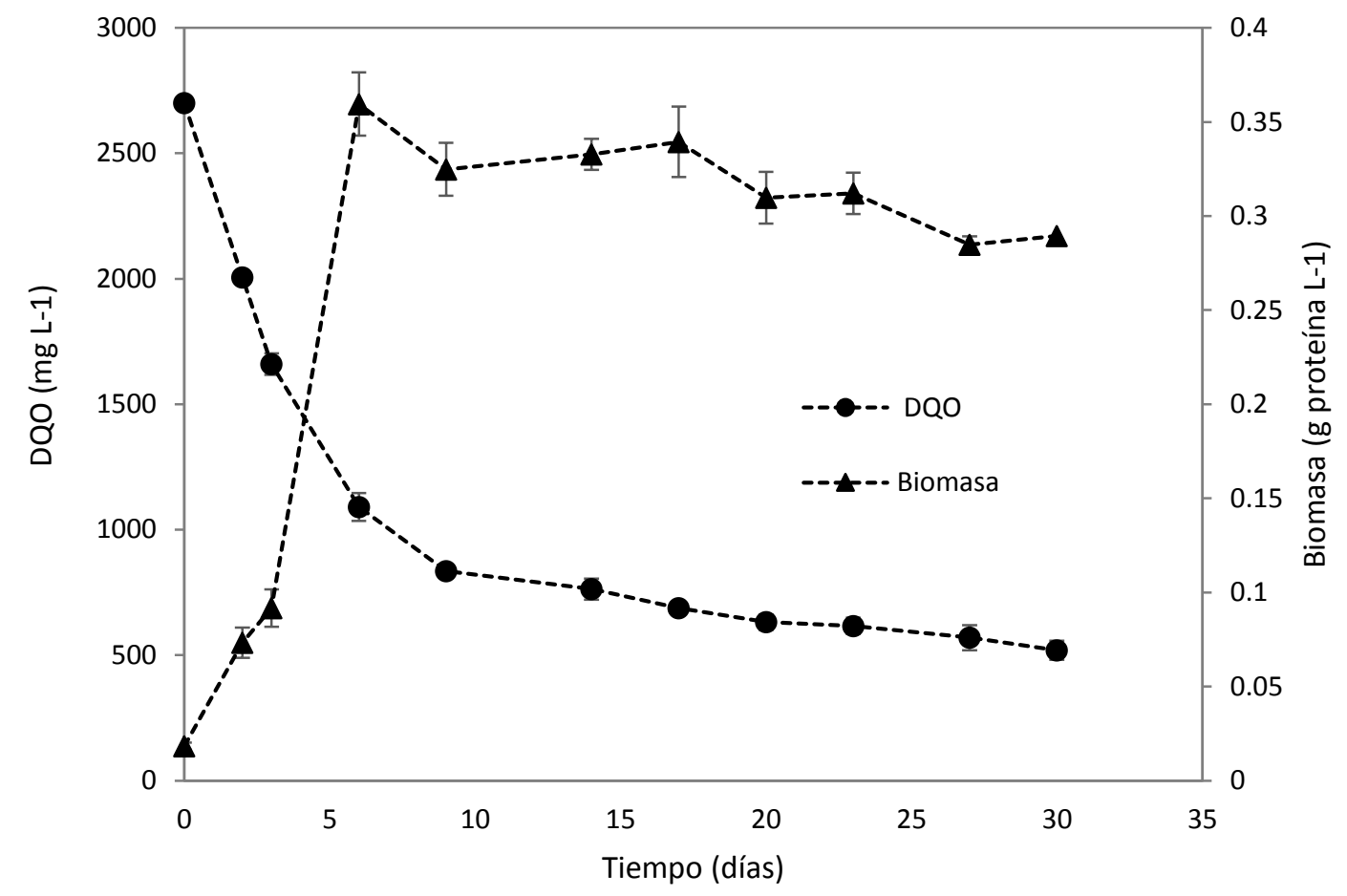

Figura 4.2. Cinéticas de biomasa y remoción de DQO por el cultivo IZT en un proceso en lote bajo iluminación continua.

Con base a los resultados del ensayo en lote se preparó el primer experimento en lote secuencial con un TRH de 30 días que es el tiempo que duró la producción de hidrógeno en lote, éste se eligió con la finalidad de asegurar la mayor remoción de DQO. Se estableció una frecuencia de recambio cada 7 días retirando $25 \%$ del volumen del cultivo y agregando DFE fresco para logar una DQO de $2800 \mathrm{mg}$ $\mathrm{L}^{-1}$. Inicialmente, los experimentos operaron en lote por 11 días, posteriormente se inició la operación en lote secuencial. En la figura 4.3 se presenta la cinética de producción de hidrógeno, la línea punteada indica el volumen de hidrógeno registrado cada 2-3 días (después de cuantificar el hidrógeno producido). La cinética de línea continua representa la Pacum $\mathrm{H}_{2}$. En estas cinéticas puede notarse que entre el día 4 y 11 se tienen la producción más alta de hidrógeno, la producción de hidrógeno empezó a disminuir posterior al primer ciclo o recambio de DFE (ver línea punteada). 


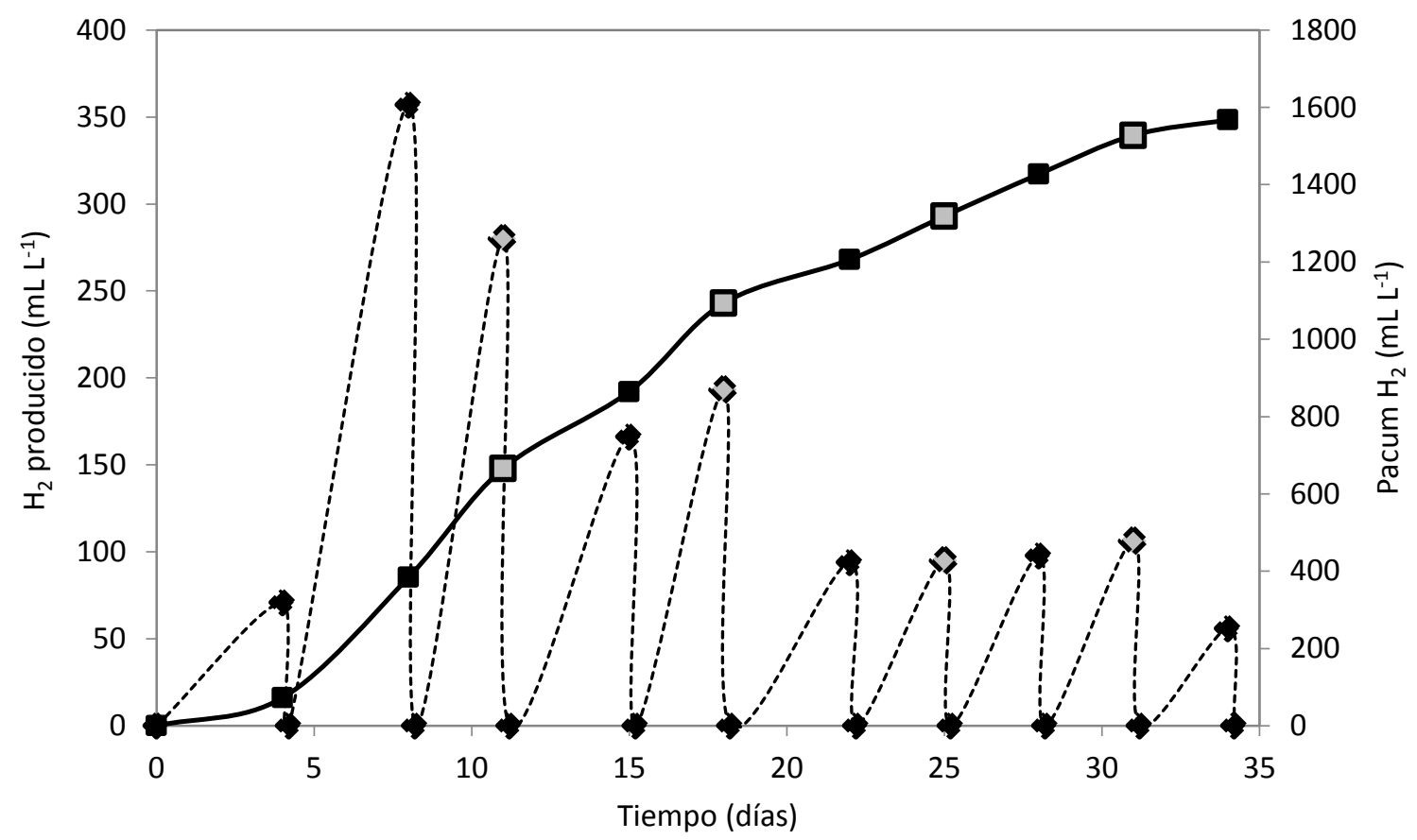

Figura 4.3. Producción de hidrógeno por el cultivo IZT con un TRH de 30 días. Línea punteada representa el registro cada 2-3 días y la línea continua representa producción acumulada de hidrógeno. Los puntos en gris indican el inicio de un nuevo ciclo del SBR (día en que se hizo el recambio del contenido en las unidades experimentales).

Se logró una remoción de DQO de 58\% en el día 11 (disminuyó de 2.8 a 1.18 g de DQO/L, ver figura 4.4), ese día se inicio la operación en lote secuencial y reestableció el nivel de DQO inicial, pero la producción de hidrógeno empezó a disminuir posterior a este primer ciclo. En la Figura 4.4 se presenta la evolución de la concentración de biomasa para el cultivo IZT. Se puede observar que para el día 11 la concentración de biomasa fue de $0.25 \mathrm{~g}$ proteína $\mathrm{L}^{-1}$, después del primer ciclo la concentración de biomasa aumentó sustancialmente, llegando a $0.41 \mathrm{~g}$ de proteína $\mathrm{L}^{-1}$ al día 18 , lo que pudo acasionar una inadecuada penetración de luz a los reactores y como consecuencia bajas producciones de 
hidrógeno. Por esta razón, para evitar que la concentración de biomasa aumentara tanto, en el segundo ciclo se disminuyó la DQO inicial alimentando con DFE menos concentrado, así la DQO inicial en el dia 18 fue de $2.2 \mathrm{~g} \mathrm{~L}^{-1}$; con esta medida el ciclo inició con una concentración inicial de $0.27 \mathrm{~g}$ proteína $\mathrm{L}^{-1} \mathrm{y}$ después de 7 días el nivel alcanzado fue de $0.39 \mathrm{~g}$ de proteína $\mathrm{L}^{-1}$, pero este valor no fue muy diferente que el encontrado en el ciclo anterior. La tercera vez que se remplazó contenido del reactor, la concentración de biomasa fue de $0.26 \mathrm{~g}$ proteína $\mathrm{L}^{-1}$ al inicio y el valor final para ese ciclo fue de $0.34 \mathrm{~g}$ proteína $\mathrm{L}^{-1}$. En ese momento la concentración de biomasa comenzó a disminuir, pero no mejoró la producción de hidrógeno al contrario ésta fue baja (ver figura 4.4) al igual que la remoción de DQO, después del día 18 la remoción de DQO fue de sólo 34\% (figura 4.4). De esta manera, un TRH largo no aseguró una remoción de DQO alta.

Cabe mencionar que durante los primeros 8 días los reactores se mantuvieron bajo iluminación por ciclos (30 min luz/30 min oscuridad de acuerdo a lo reportado en el capítulo 3), pero al observar la baja producción de hidrógeno en comparación con el tratamiento en lote se interrumpió la operación con fotoperiodos y se inició con iluminación continua. El inicio del recambio del sustrato (operación en lote secuencia) en conjunto con el suministro de luz continua potenció la producción de biomasa, ver figura 4.4, además un volumen de recambio del sustrato de sólo 25\% (TRH largo) propició tener altas concentraciones de biomasa. Pattanamanee et al., (2012) obsevaron un comportamiento similar con $R$. sphaerodes S10, reportana que a un volumen de intercambio del sustrato baja reduce la penetración de luz en el cultivo por el aumento de la concentración de biomasa. Con una disponibilidad reducida de luz, las células cambiaron su metabolismo para producir biomasa en lugar de hidrógeno. Con base a lo anterior, se preparó un experimento con un TRH de 15 días bajo iluminación continua, y al igual que el experimento anterior se mantuvo una frecuencia de recambio del DFE cada 7 días, pero el volumen de cultivo reemplazado en los reactores fue del $50 \%$. El primer recambio de sustrato se llevó a cabo a los 14 días y posteriormente cada 7 días. 

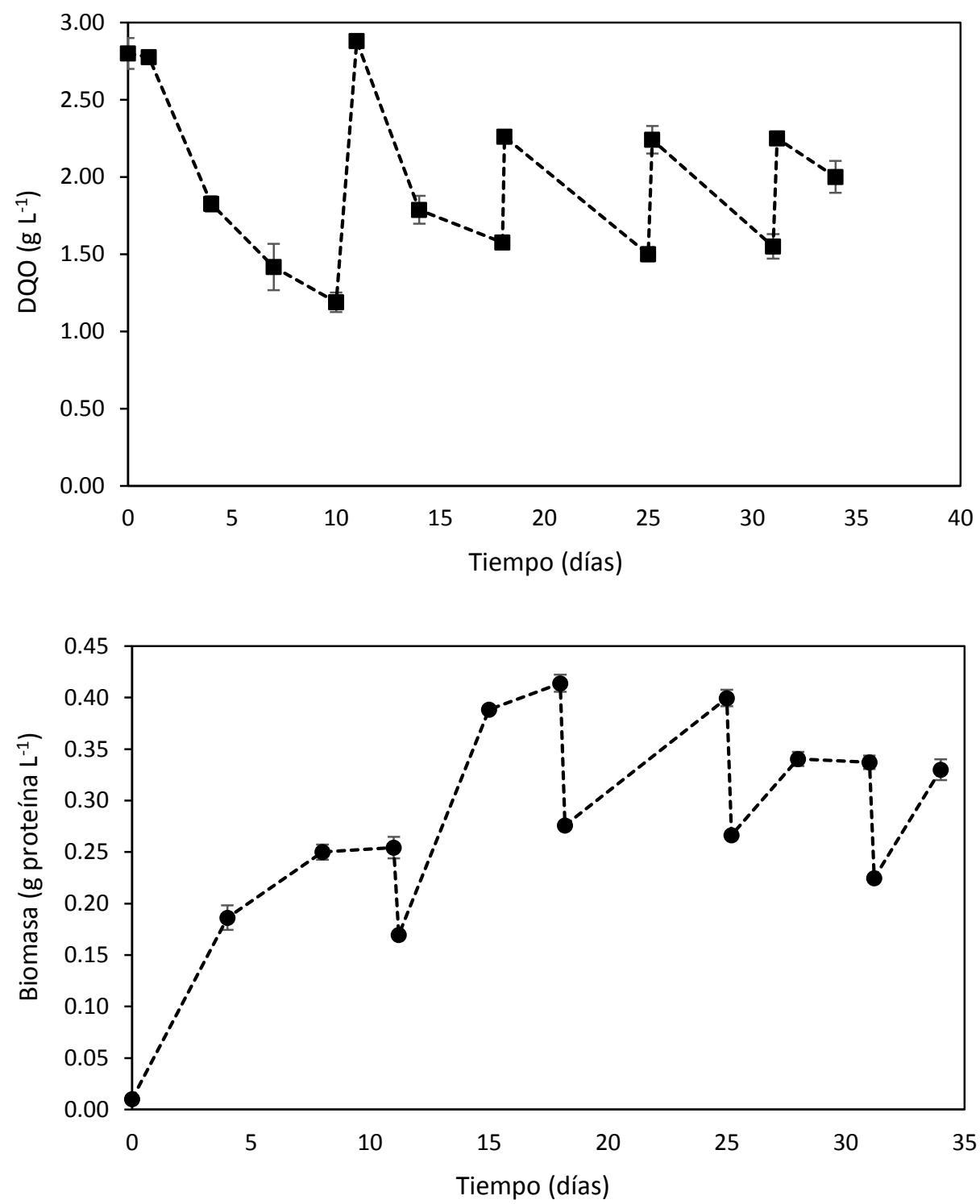

Figura 4.4. Cinética de remoción de DQO (arriba) y producción de biomasa (abajo) por el cultivo IZT con un TRH de 30 días.

En la figura 4.5 se presenta la cinética de producción de hidrógeno para este tratamiento en lote secuencial y se puede observar que se logró una producción de hidrógeno constante a lo largo de los 
42 días de operación sin variaciones importantes (la pendiente de la recta se mantiene). La producción de hidrógeno fue mayor que en el experimento con un recambio de $25 \%$ del volumen del reactor. En este experimento la Pacum $\mathrm{H}_{2}$ para el día 35 fue de $3530 \mathrm{~mL}$ y para el experimento anterior fue sólo de $1600 \mathrm{~mL}$ (ver figuras 4.3 y 4.5). Kim \& Kim (2012), realizaron experimentos de producción de hidrógeno variando el volumen de recambio del $30 \%$ al $70 \%$ correspondiendo a un TRH de $34-84 \mathrm{~h}$, con el volumen de recambio del $60 \%$ se obtuvo la producción de hidrógeno más alta $\left(3.7 \mathrm{~mol} \mathrm{H}_{2} \mathrm{~mol}^{-}\right.$ ${ }^{1}$ succinato). En cambio con el volumen de recambio del $30 \%$ el rendimiento fue sólo $0.2 \mathrm{~mol} \mathrm{H}_{2} \mathrm{~mol}^{-1}$ succinato y el $70 \%$ del flujo de electrones del sustrato se desvío a la producción de biomasa. Oncel \& Vardar-Sukar (2008) estudiaron dos volúmenes de recambio, 30\% y 50\%, y encontraron que al reemplazar el $50 \%$ del volumen del reactor se obtenían las producciones más altas de $\mathrm{H}_{2}$. Pattanamanee et al. (2012) probaron tres volumenes de recambio del sustrato: 50\%, 70\% y $90 \%$, reemplazando $90 \%$ del susutrato obtuveon la Pacum $\mathrm{H}_{2}$ más alta $\left(1207 \mathrm{~mL} \mathrm{H}_{2} / \mathrm{L}\right)$

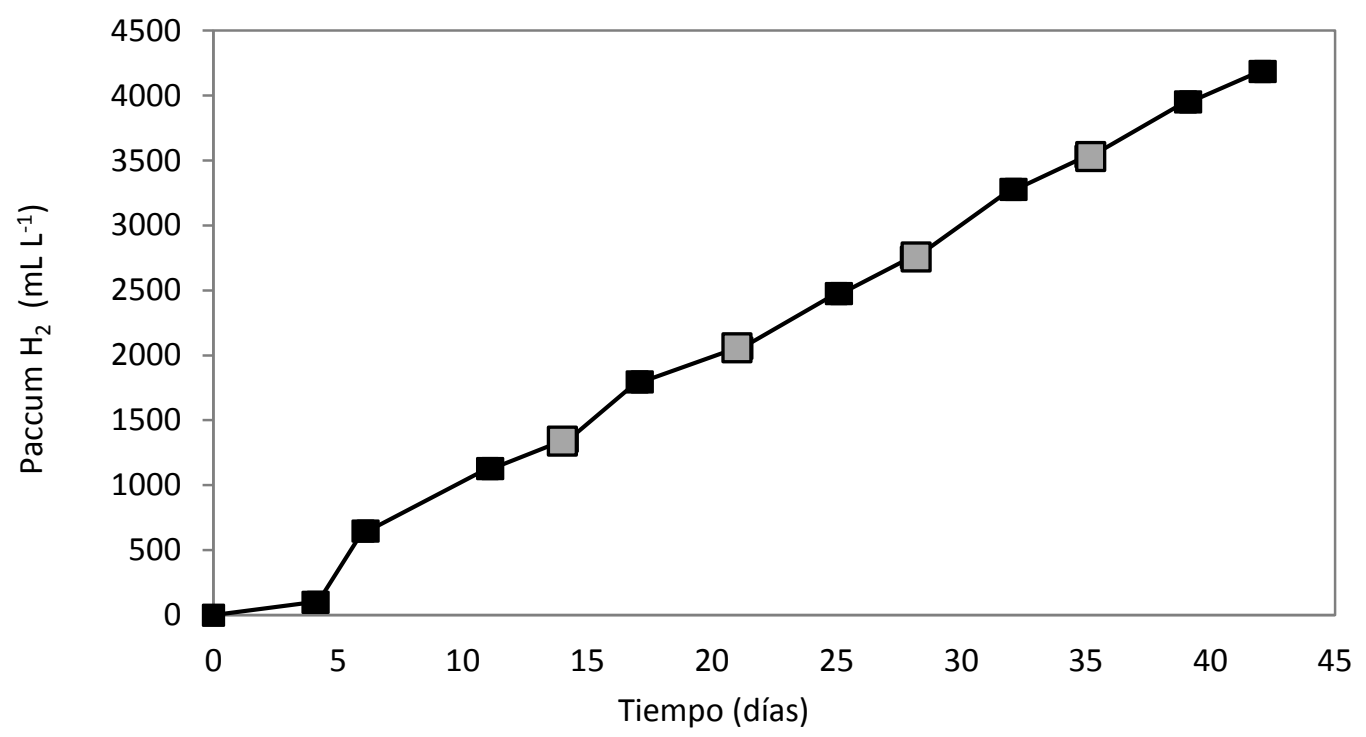

Figura 4.5. Producción de hidrógeno por el cultivo IZT con un TRH de 15 días. Los puntos en gris indican los días en que se inicio de un nuevo ciclo del SBR. 
La figura 4.6 muestra la evolución de la DQO y ácido butírico, la DQO inicial después de cada ciclo fue de $2.5 \mathrm{~g} \mathrm{~L}^{-1}$ aproximadamente, lo cual fue menor al valor de $3.3 \mathrm{~g} \mathrm{~L}^{-1}$ con el que se inició la operación de los reactores para este experimento. Como se puede notar durante los primeros 14 días la DQO bajó de $3.3 \mathrm{~g} \mathrm{~L}^{-1}$ a $0.7 \mathrm{~g} \mathrm{~L}^{-1}$ lo cual representa una remoción del $78 \%$, posteriormente para los siguientes ciclos la remoción fue del 63 \% y este porcentaje de remoción se alcanzó en tan sólo 7 días. Con respecto a la remoción de ácido butírico, en los primeros 14 días se removió por completo y posteriormente al iniciar la operación en lote secuencial, la remoción fue de 600 ppm después de 7 días quedando un remanente de 100 ppm con respecto a la alimentación inicial a cada ciclo. extracto acidogénico empleado para este experimento tiene un alto contenido de ácido butírico (11.6 g/L) y pequeñas cantidades de ácido acético y propiónico, es por eso que sólo se presenta la cinética de remoción del butírico, los otros dos ácidos se consumen en su totalidad en los primeros 3 días. En la figura 4.7 se puede ver que al día 14 los reactores alcanzan una concentración de biomasa de $0.33 \mathrm{~g}$ de proteína $\mathrm{L}^{-1}$, cuando se inician la operación en lote secuencial, la biomasa baja hasta $0.15 \mathrm{~g}$ de proteína $\mathrm{L}^{-1}$, y después del primer ciclo se alcanzan valores de $0.30 \mathrm{~g}$ proteína $\mathrm{L}^{-1}$, $\mathrm{lo}$ cual es más bajo que en el primer experimento donde la concentración de biomasa alcanzó hasta $0.41 \mathrm{~g}$ proteína $L^{-1}$. 


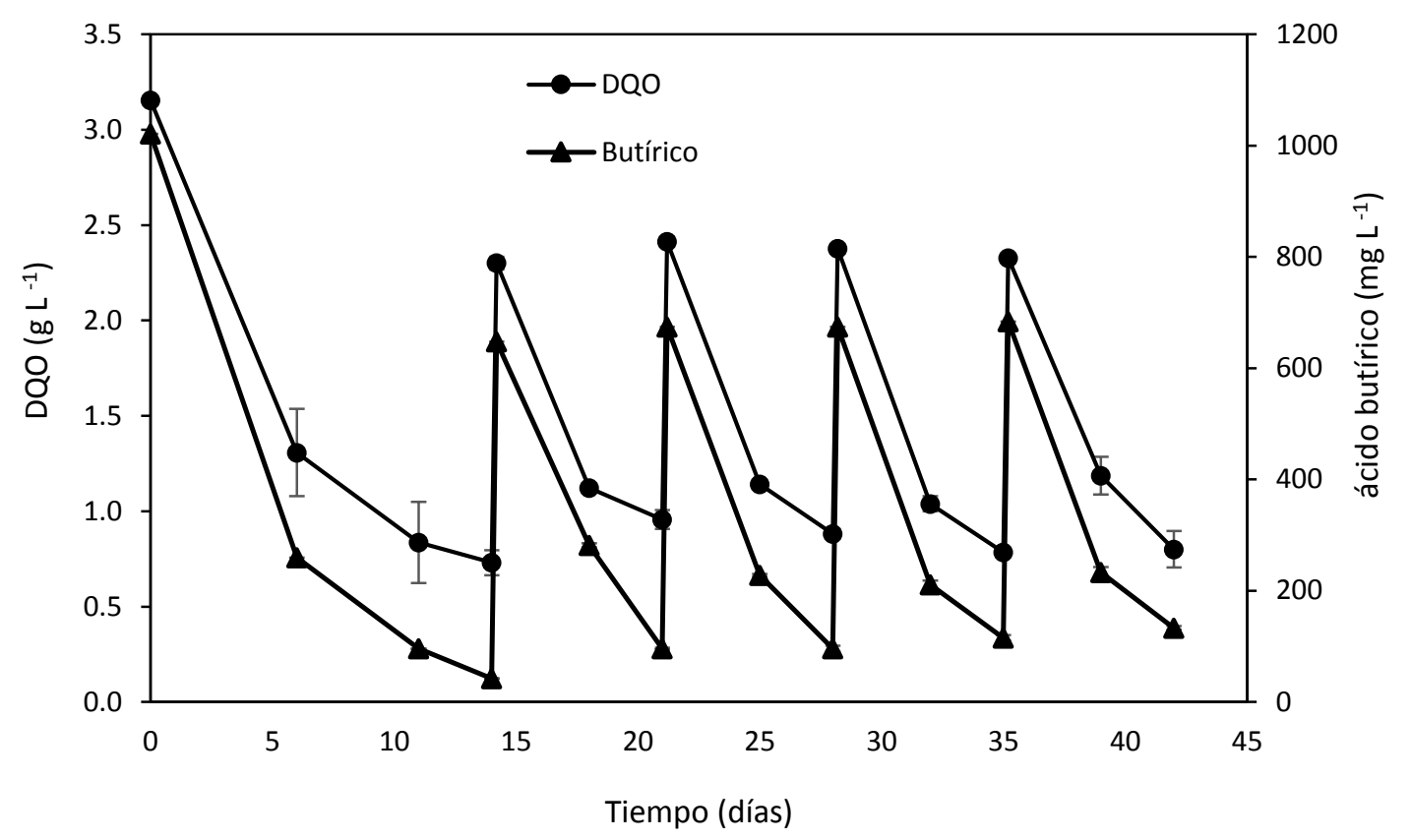

Figura 4.6. Cinética de remoción de DQO y ácido butírico por el cultivo IZT con un TRH de 15 días

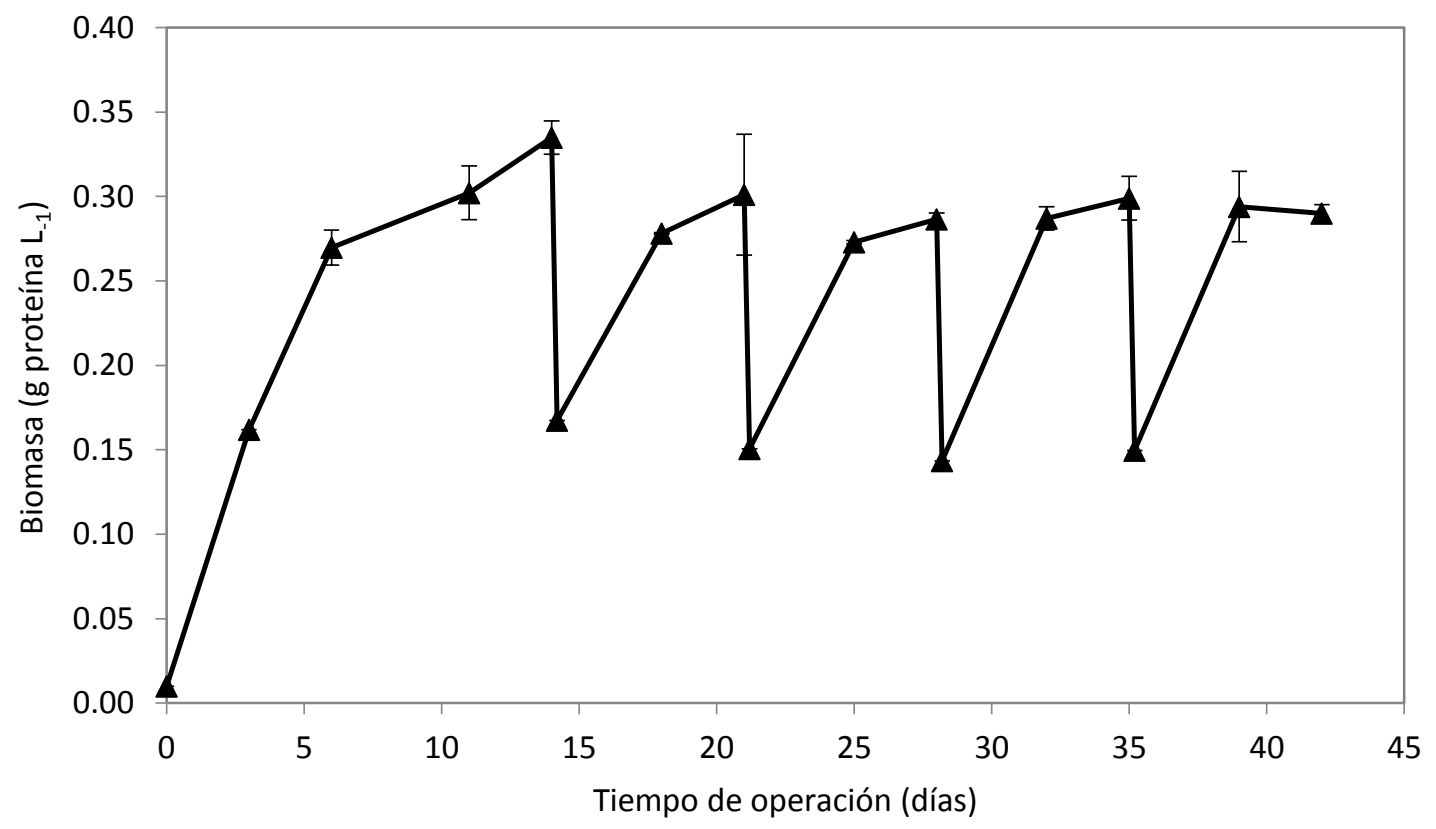

Figura 4.7. Cinéticas de producción de biomasa por el cultivo IZT con un TRH de 15 días 
Con base en los resultados del capítulo 3, donde se encontró que el cultivo IZT fue capaz de mantener la misma producción de hidrógeno en los tratamientos en lote bajo ciclos de luz-oscuridad de 30 minutos que bajo iluminación continua, y al hecho de que se que se logró estabilizar la producción de hidrógeno en el modo de operación lote secuencial con un TRH de 15 días, se operaron los reactores bajo dos patrones de iluminación: (tratamiento SBR 3A) ciclos luz-oscuridad de 30 min y (tratamiento SBR 3B) 12 horas luz continua-12 horas con ciclos de 30 min luz-oscuridad.

En la figura 4.8 se muestran las cinéticas de producción de hidrógeno para los dos tratamientos. En ambos casos la Paccum $\mathrm{H}_{2}$ durante la operación en lote fue similar. El tratamiento SBR 3A en la operación en lote secuencial mantiene la producción de $\mathrm{H}_{2}$ hasta el día 30 mientras que el tratamiento SBR 3B lo hace por más de 40 días.

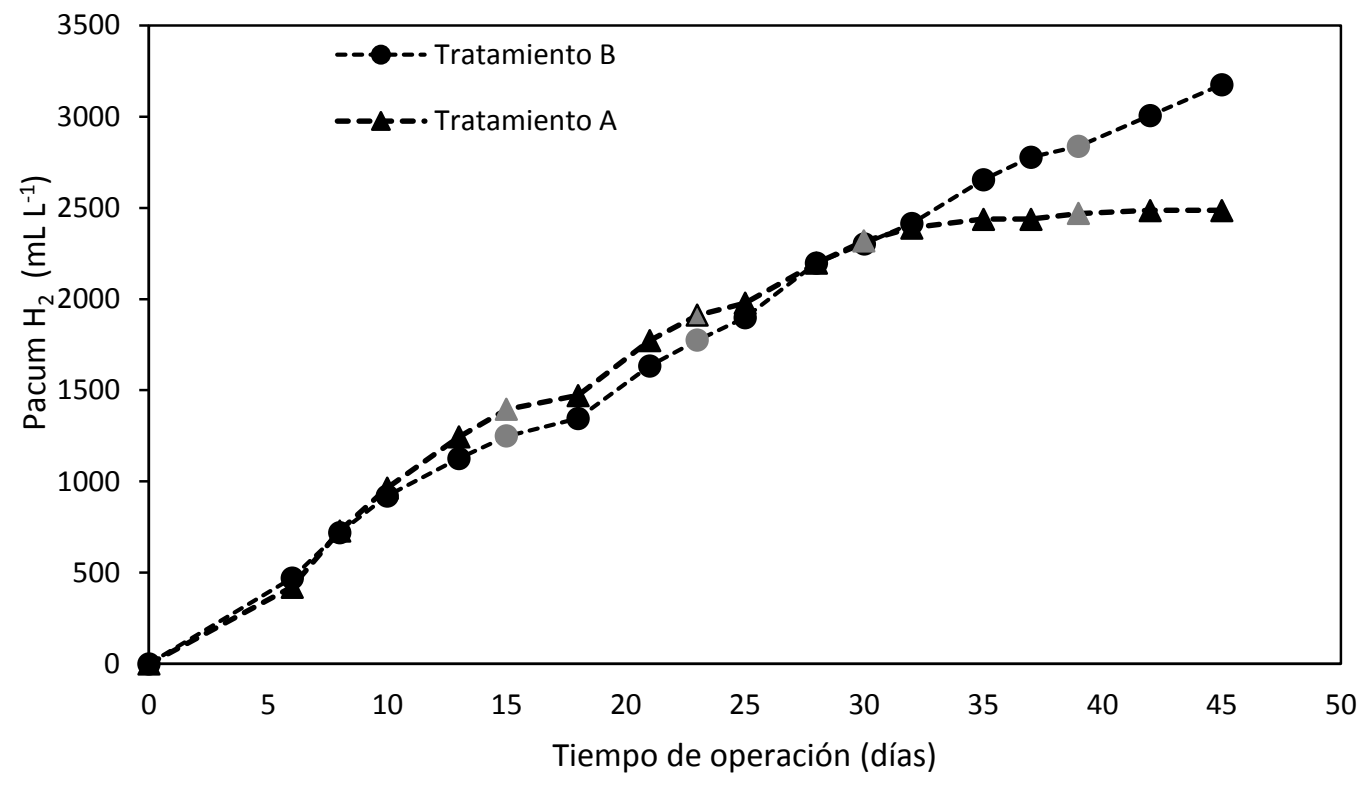

Figura 4.8. Producción de hidrógeno por el cultivo IZT con un TRH de 15 días bajo dos patrones de iluminación: (tratamiento SBR 3A) ciclos luz-oscuridad de 30 min y (tratamiento SBR 3B) 12 horas luz continua-12 horas con ciclos de 30 min luz-oscuridad. Los puntos en gris indican el inicio de cada ciclo de la operación de SBR. 
En las figuras 4.9 y 4.10 se muestran la evolución de la DQO, ácido butírico y concentración de biomasa para los experimentos con fotoperiodos. Durante los primeros 15 días de operación, la remoción de $\mathrm{DQO}$ fue del $84 \%$ para ambos tratamientos, posteriormente se mantuvo en $60 \%$ para el tratamiento SBR 3B. El tratamiento SBR 3A presentó una mayor remoción de DQO entre los días 23 y 30, lo cual se correlaciona una mayor concentración de biomasa en este periodo (figura 4.10). Posterior al día 30 y aunque la producción de hidrógeno fue casi nula se presentó remoción de DQO debido al consumo del sustrato para el crecimiento/mantenimiento de biomasa. Como se puede observar, durante los primeros 15 días, la producción de biomasa en el tratamiento SBR 3A es menor al tratamiento SBR 3B, es posible que esto se deba a que el tratamiento SBR 3A estuvo expuesta globalmente a un menor tiempo de luz. Se ha reportado que la iluminación continua permite a los cultivos obtener suficiente ATP para el crecimiento celular y la producción de hidrógeno; mientras que bajo ciclos de luz-oscuridad, los microorganismos se tardan más tiempo para producir las mismas cantidades de ATP (Li et al., 2011; Sargsyan et al., 2015; Uyar et al., 2007).

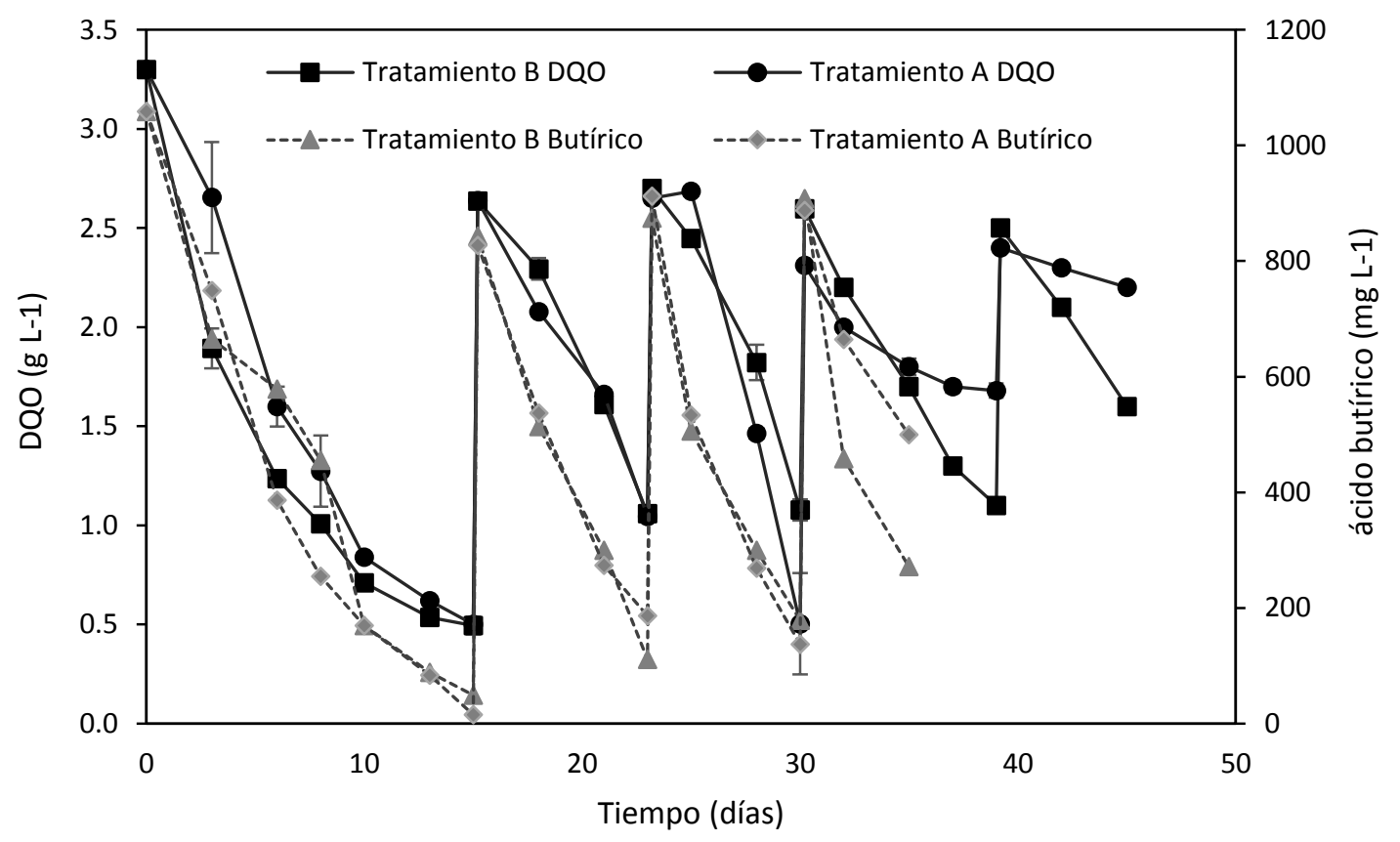

Figura 4.9. Cinéticas de remoción de DQO y ácido butírico por el cultivo IZT con un TRH de 15 días para los tratamiento SBR 3A y SBR 3B bajo ciclos luz-oscuridad. 


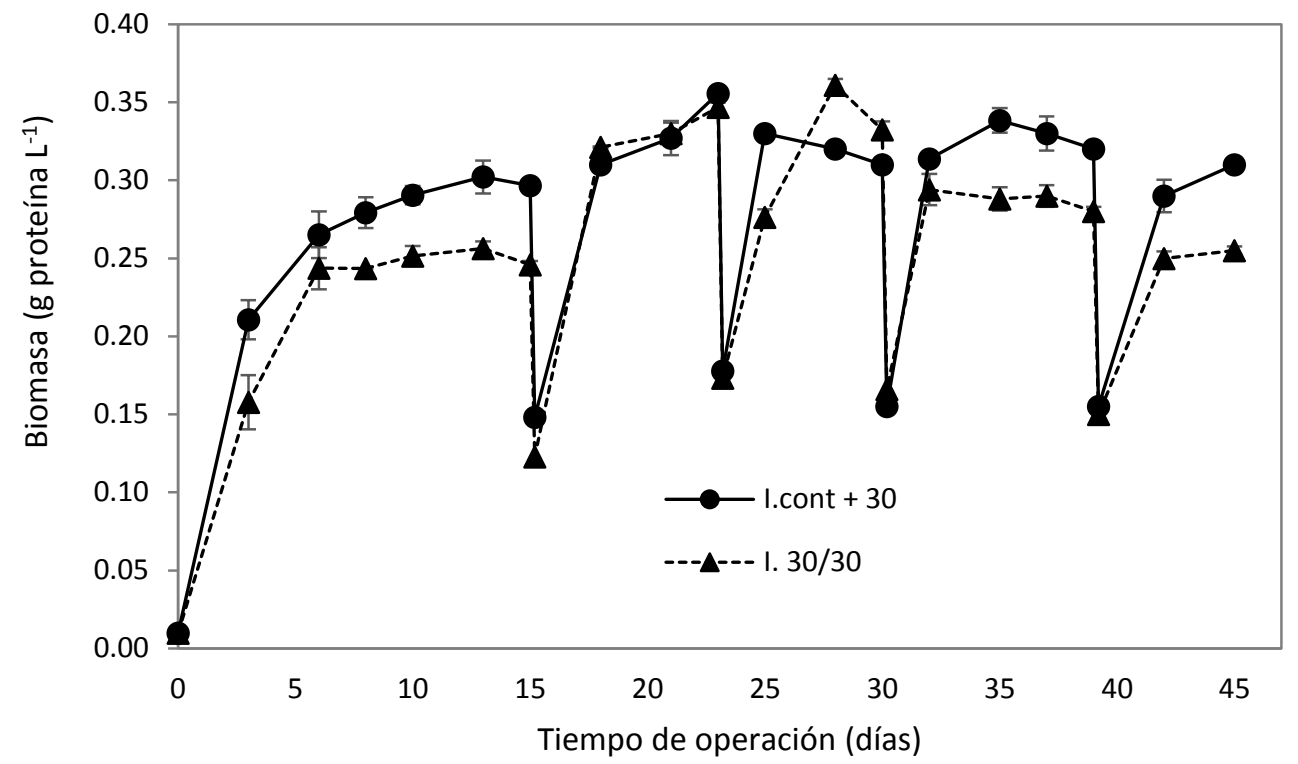

Figura 4.10. Cinéticas de producción de biomasa para los tratamiento SBR 3A y SBR 3B bajo ciclos luz-oscuridad.

En el experimento anterior (lote secuencial bajo iluminación continua), durante la operación en lote la biomasa alcanza su máxima concentración $\left(0.33 \mathrm{~g}\right.$ proteína $\left.\mathrm{L}^{-1}\right)$ y durante la operación en lote secuencial, ésta se mantiene por debajo de $0.33 \mathrm{~g}$ proteína $\mathrm{L}^{-1}$. En este experimento con fotoperiodos tanto en el tratamiento SBR 3A y SBR 3B sucede lo contrario, la concentración de biomasa es más baja en la operación en lote $\left(0.25\right.$ y $0.30 \mathrm{~g}$ proteína $\mathrm{L}^{-1}$, respectivamente) y la máxima concentración (cerca de $0.35 \mathrm{~g}$ proteína $\mathrm{L}^{-1}$ ) se alcanzó en la operación en lote secuencial. Al parecer los fotoperidos en la operación en lote, limitan el crecimiento de la biomasa, pero en la operación en lote secuencial al suministrar sustrato fresco se estimula la producción de biomasa, la producción de biomasa sucede tanto en presencia como en ausencia de luz, pero la producción de $\mathrm{H}_{2}$ sólo se presenta bajo la presencia obligada de luz (Uyar et al., 2007).

En la Tabla 4.1 se muestra un resumen de los resultados obtenidos en todos los tratamientos realizados en este capítulo. El experimento en lote secuencial bajo iluminación continua y TRH de 15 
días (SBR-2) es el que alcanzó mayor producción de $\mathrm{H}_{2}$, mientras que los tratamientos SBR 3A y SBR 3B alcanzan producciones de hidrógeno muy similares al día 32. En el experimento SBR 2 SBR 3A y SBR 3B durante la operación en lote alcanzan producciones de hidrógeno muy similares, lo cual corrobora lo encontrado en el capítulo 3, donde el cultivo IZT fue capaz de producir la misma cantidad de hidrógeno bajo iluminación continua y ciclos luz-oscuridad, pero una vez que inició la operación en lote secuencial la producción de hidrógeno en los tratamientos SBR 3A y SBR 3B disminuyó (cambio la pendiente), lo cual podemos relacionar con el hecho de que en estos tratamientos una vez que inició la operación en lote secuencial, la concentración de biomasa aumentó. En el tratamiento SBR 2 hubo menor concentración de biomasa, lo cual propicia una mejor distribución de la luz en el cultivo y por lo tanto una mayor producción de hidrógeno. Cabe resaltar que aunque la cantidad de hidrógeno bajo ciclos luz oscuridad en lote secuencial (tratamiento SBR 3A) fue menor que bajo iluminación continua en un 30\% (calculado para el día 32), no debe considerarse despreciable tomando en cuenta el ahorro de energía.

Las tasas de producción de hidrógeno se pueden ver en la Tabla 4.1, la tasa más alta se obtuvo en el experimento en lote $\left(6.1 \mathrm{~mL} \mathrm{H}_{2} \mathrm{~L}^{-1} \mathrm{~h}^{-1}\right)$, seguida por la del experimento SBR $2\left(4.3 \mathrm{~mL} \mathrm{H}_{2} \mathrm{~L}^{-1} \mathrm{~h}^{-1}\right)$, en tercer lugar quedaron los experimentos SBR-3A y SBR-3B con una tasa de $3.1 \mathrm{~mL} \mathrm{H}_{2} \mathrm{~L}^{-1} \mathrm{~h}^{-1}$ (calculada hasta el día 32) y la tasa más baja se obtuvo en el experimento SBR-1 con un TRH de 30 días. Pattanamanee et al., (2012) realizaron experimentos de producción de hidrógeno en lote secuencial, y al igual que en este trabajo ellos obtuvieron una tasa de producción de $\mathrm{H}_{2}$ más alta en la operación en lote y menor en la operación en lote secuencial. 
Tabla 4.1. Resumen de los resultados obtenidos para los tratamientos en lote y lote secuencial.

\begin{tabular}{|c|c|c|c|c|c|c|}
\hline Sistema & $\begin{array}{l}\text { Duración } \\
\text { (dias) }\end{array}$ & $\begin{array}{l}\text { Pacum } \mathrm{H}_{2} \\
\left(\mathrm{~mL} \mathrm{H} \mathrm{L}_{2} \mathrm{~L}^{-1}\right)\end{array}$ & $\begin{array}{l}\text { Remoción } \\
\text { DQO (\%) }\end{array}$ & $\begin{array}{l}\text { Biomasa } \\
\text { (g prot.L-1) }\end{array}$ & $\begin{array}{l}\text { Régimen } \\
\text { de ilumin. }\end{array}$ & $\begin{array}{c}\text { Tasas de produc. } \\
\text { de } \mathrm{H}_{2} \\
\text { Potencial de } \\
\text { produc. } \mathrm{H}_{2}\end{array}$ \\
\hline Batch & 30 & 1331 & 81 & 0.33 & $\begin{array}{l}\text { Iluminación } \\
\text { continua }\end{array}$ & $\begin{array}{l}6.1 \mathrm{~mL} \mathrm{H}_{2} \mathrm{~L}^{-1} \mathrm{~h}^{-1} \\
15.1 \mathrm{~L} \mathrm{H}_{2} \mathrm{~L}^{-1} \mathrm{DFE}\end{array}$ \\
\hline \multicolumn{7}{|c|}{ Tratamientos en semi- continuo } \\
\hline SBR-1 & \multicolumn{5}{|c|}{ Duración del ciclo del SBR: 7 días; vol. de recambio: 25\%; TRH: 30 días } & \\
\hline \multirow[t]{4}{*}{$\begin{array}{l}\text { Inicio de SBR: } \\
\text { día } 11\end{array}$} & Lote & 665 & 57 & 0.25 & \multirow{5}{*}{$\begin{array}{l}\text { Iluminación } \\
\text { continua }\end{array}$} & \multirow{5}{*}{$2.7 \mathrm{~mL} \mathrm{H}_{2} \mathrm{~L}^{-1} \mathrm{~h}^{-1}$} \\
\hline & Ciclo 1 & 1093 & 46 & 0.39 & & \\
\hline & Ciclo 2 & 1318 & 34 & 0.39 & & \\
\hline & Ciclo 3 & 1527 & 30 & 0.33 & & \\
\hline Total (días) & 34 & 1567 & 11 & 0.33 & & \\
\hline SBR-2 & \multicolumn{5}{|c|}{ Duración del ciclo del SBR: 7 días; vol. de recambio: 50\%; TRH: 15 días } & \\
\hline \multirow[t]{4}{*}{$\begin{array}{l}\text { Inicio de SBR: } \\
\quad \text { día } 14\end{array}$} & Lote & 1505 & 77 & 0.33 & \multirow{5}{*}{$\begin{array}{l}\text { lluminación } \\
\text { continua }\end{array}$} & \multirow{5}{*}{$\begin{array}{l}\text { 4.3 } \mathrm{mL} \mathrm{H}_{2} \mathrm{~L}^{-1} \mathrm{~h}^{-1} \\
\text { 13.7 L H} \mathrm{L} \mathrm{L}^{-1} \mathrm{DFE}\end{array}$} \\
\hline & Ciclo 1 & 2266 & 58 & 0.30 & & \\
\hline & Ciclo 2 & 2956 & 63 & 0.28 & & \\
\hline & Ciclo 3 & 3655 & 67 & 0.29 & & \\
\hline Total (días) & 42 & 4240 & 65 & 0.29 & & \\
\hline SBR-3 A & \multicolumn{5}{|c|}{ 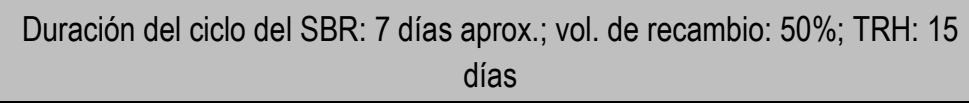 } & \\
\hline \multirow[t]{4}{*}{$\begin{array}{l}\text { Inicio de } \\
\text { SBR:dia } 15\end{array}$} & Lote & 1394 & 84 & 0.25 & \multirow{5}{*}{$\begin{array}{l}\text { Ciclos luz- } \\
\text { oscuridad } \\
\text { de30 } \\
\text { minutos }\end{array}$} & \multirow{5}{*}{$\begin{array}{l}3.1 \mathrm{~mL} \mathrm{H}_{2} \mathrm{~L}^{-1} \mathrm{~h}^{-1} \\
\text { 8.2 L H} \mathrm{L}^{-1} \mathrm{DFE}\end{array}$} \\
\hline & Ciclo 1 & 1910 & 60 & 0.35 & & \\
\hline & Ciclo 2 & 2318 & 80 & 0.33 & & \\
\hline & Ciclo 3 & 2467 & 27 & 0.28 & & \\
\hline Total (días) & 45 & 2485 & 8 & 0.25 & & \\
\hline SBR-3 B & \multicolumn{5}{|c|}{$\begin{array}{l}\text { Duración del ciclo del SBR: } 7 \text { días aprox.; vol. de recambio: 50\%; TRH: } 15 \\
\text { días }\end{array}$} & \\
\hline \multirow[t]{4}{*}{$\begin{array}{l}\text { Inicio de } \\
\text { SBR:día } 15\end{array}$} & Lote & 1248 & 85 & 0.296 & \multirow{5}{*}{$\begin{array}{c}12 \mathrm{~h} \text { luz } \\
\text { cont. + } 12 \mathrm{~h} \\
\text { ciclos luz- } \\
\text { oscuridad } \\
\text { de } 30 \text { min. }\end{array}$} & \multirow{5}{*}{$\begin{array}{l}3.1 \mathrm{~mL} \mathrm{H}_{2} \mathrm{~L}^{-1} \mathrm{~h}^{-1} \\
\text { 10.4 L H} \mathrm{LL}^{-1} \mathrm{DFE}\end{array}$} \\
\hline & Ciclo 1 & 1773 & 60 & 0.35 & & \\
\hline & Ciclo 2 & 2302 & 60 & 0.31 & & \\
\hline & Ciclo 3 & 2837 & 58 & 0.32 & & \\
\hline Total (días) & 45 & 3175 & 36 & 0.31 & & \\
\hline
\end{tabular}


Es importante señalar que las tasas de producción de hidrógeno y rendimientos están influenciadas por el tipo de microorganismo, condiciones de operación y el sustrato, con sustratos fácilmente asimilables por las BPNS como el succinato y malato se pueden obtener tasas muy altas como lo reportan Kim \& Kim (2012), pero cuando se emplean AGVs que no entran directamente al ciclos de los ácidos tricarboxílicos o se emplean sustratos complejos las tasas pueden ser muy bajas como las reportadas por Eroglu et al. (2008): $2 \mathrm{~mL} \mathrm{H}_{2} \mathrm{~L}^{-1} \mathrm{~h}^{-1}$ cuando emplean ácido láctico y $3 \mathrm{~mL} \mathrm{H} \mathrm{L}^{-1} \mathrm{~h}^{-1}$ cuando usan agua residual generada durante el procesamiento de aceitunas con una concentración del $4 \%$.

\subsection{Identification del cultivo fotoheterótrofo IZT}

En la figura 4.11 se muestra el perfil de DGGE del cultivo IZT (carril 1), y como controles en carril 2, $R$. Palustris, y en carril 3, R. capsulatus. Los tres microorganismos están representados por varias bandas bajo las condiciones en las que se corrió el DGGE. Un microorganismo puede estar representado por varias bandas debido a la microheterogeneidad en las secuencias de algunos genes, como ocurre con la secuencias ribososmales (Clayton et al., 1996). Se escogieron cuatro bandas representativas del cultivo IZT, 3 de $R$. palustris y 4 de $R$. capsulatus para secuenciar.

Se obtuvieron las secuencias del gen 16s rDNA (de 500 bp) de los cultivos y se sometieron al $\mathrm{NBCl}$ para buscar las secuencias más cercanas o parecidas por BLAST. Las secuencias del 16S rDNA del cultivo IZT tuvieron alta similitud (99\%) con Rhodopseudomonas palustris DX1. En la tabla 4.2 se presentan los resultados del alineamiento por BLAST de las secuencias de las bandas representativas de los tres cultivos que se eligieron para analizar. 


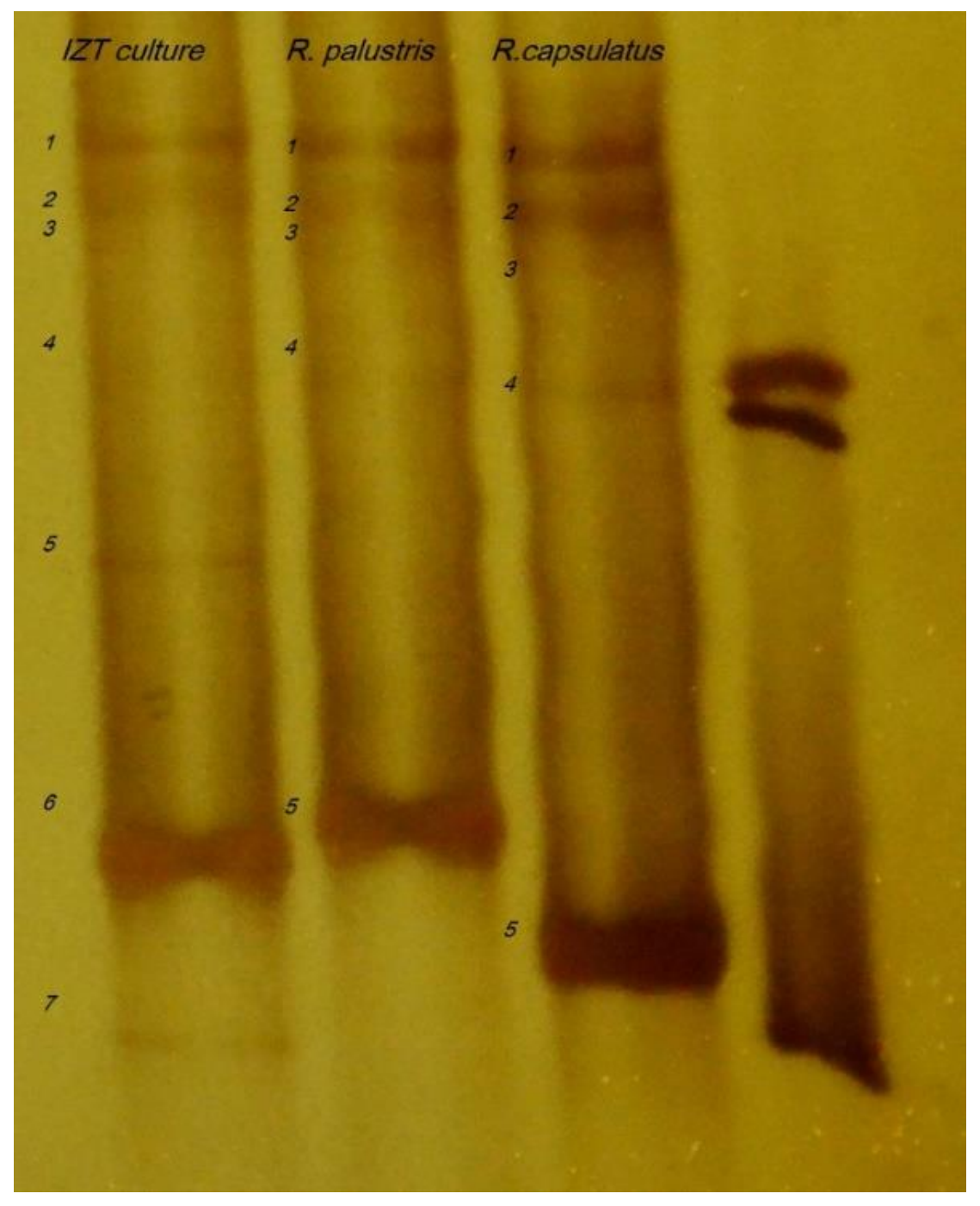

Figura 4.11. Patrón de bandas en el DGGE para el cultivo IZT (carril 1), $R$. palustris (carril 2) y $R$. capsulatus (carril 3) y el marcador molecular (carril 4). 
Tabla 4.2. Resultados para las bandas secuenciadas del cultivo IZT, R. palustris y $R$. capsulatus.

\begin{tabular}{ll} 
Banda & \multicolumn{1}{c}{ BLAST } \\
IZT 1 & Rhodopseudomonas palustris DX1 (similarity 99\%) \\
IZT 5 & Rhodopseudomonas palustris DX1 (similarity 99\%) \\
IZT 6 & Rhodopseudomonas palustris DX1 (similarity 99\%) \\
IZT 7 & Rhodopseudomonas palustris DX1 (similarity 99\%) \\
\hline PAL 2 & Rhodopseudomonas palustris ATCC 17003 (similarity 99\%) \\
PAL 4 & Rhodopseudomonas palustris ATCC 17003 (similarity 99\%) \\
PAL 5 & Rhodopseudomonas palustris ATCC 17003 (similarity 99\%) \\
\hline CAP 1 & Rhodobacter capsulatus SB 1003 (similarity 99\%) \\
CAP 2 & Rhodobacter capsulatus SB 1003 (similarity 99\%) \\
CAP 3 & Rhodobacter capsulatus SB 1003 (similarity 99\%) \\
CAP 5 & Rhodobacter capsulatus SB 1003 (similarity 99\%) \\
\hline
\end{tabular}

\subsection{Conclusiones}

Ésta es la primera vez que se trabaja en lote secuencial bajo ciclos luz-oscuridad, lo que permite no sólo a mantener la producción de hidrógeno constante por períodos largos sino también contribuir a bajar el consumo de energía del proceso.

Algunos autores han reportado que la producción de hidrógeno bajo condiciones ambientales no es factible o es baja por los largos periodos de oscuridad en las noches, para remediar este hecho se podría implementar iluminación por fotoperíodos en la noche como en el tratamiento SBR 3B.

Con respecto a la identidad de los microorganismos constituyentes del cultivo IZT, se encontró que éste está constituido por una bacteria con $99 \%$ de similitud a $R$. palustris DX1. 


\section{CAPÍTULO 5}

\section{OBTENCIÓN DE EFLUENTES DE FERMENTACIÓN OSCURA Y SU UTILIZACIÓN PARA LA PRODUCCIÓN DE HIDRÓGENO}

Parte de los resultados de este capítulo fueron publicados en la revista "Química Hoy Chemistry Sciences" (Ver apéndice 4).

\subsection{Introducción}

Para los experimentos de los capítulos 2, 3 y 4 se emplearon los DFE donados por la Dra. Inés García Peña de la Unidad Profesional Interdisciplinaria de Biotecnología del IPN (denominados DFE-UPIBI), pero una vez que estos se agotaron fue necesario producir DFE propios (desde ahora denominados DFE-UAM) para continuar con las actividades de esta tesis. La implementación de esta actividad no fue planeada inicialmente, sin embargo resultó en una oportunidad valiosa para probar la actividad productora de hidrógeno de un inóculo anaerobio propio de la UAM, y encontrar condiciones prácticas y económicas para la producción de $\mathrm{H}_{2}$ por fermentación oscura al mismo tiempo de obtener los DFE para la producción de $\mathrm{H}_{2}$ por fotofermentación.

Como se mencionó en la sección de antecedentes de esta tesis, en la literatura predominan los trabajos de fermentación oscura llevados a cabo bajo condiciones controladas de laboratorio, que 
resultan poco prácticas cuando se requieren escalar los sistemas, como el uso de sustratos modelo o residuos suplementados con micronutrientes inorgánicos, utilización de consorcios tratados térmicamente por ebullición o químicamente (para la selección de las bacterias productoras de hidrógeno), purgado con nitrógeno para propiciar condiciones anaerobias (y baja presión parcial de hidrógeno), además del ajuste inicial del pH y/o control automático del mismo con la utilización de amortiguadores químicos comerciales. Una de las desventajas principales de los sistemas de fermentación oscura es el alto consumo de alcalinidad externa para mantener el sistema en el rango de $\mathrm{pH}$ deseado. Cuando los sustratos son residuos ricos en carbohidratos, los suplementos de alcalinidad adicional pueden contribuir a elevar los costos de manera considerable (RedondasMonteserrín, 2013).

Por estas razones, en esta actividad se llevó a cabo la producción de hidrógeno por fermentación oscura utilizando: 1) residuos vegetales como sustrato sin suplementos inorgánicos; 2) un inóculo anaerobio proveniente de un reactor metanogénico tratado alternativamente con microondas; 3) presión reducida en lugar del gas nitrógeno, para establecer condiciones anaerobias y bajar la presión parcial de hidrógeno en los reactores y 4) harina de cascarón de huevo (CH) como amortiguador de pH con base a un trabajo previo (Montiel-Corona et al., 2010) con la finalidad de reducir costos.

Posteriormente, se realizaron ensayos de producción de hidrógeno por fotofermentación a fin de reproducir los resultados que previamente se obtuvieron con los DFE- UPIBI (capítulo 2) pero ahora utilizando DFE-UAM propios.

\subsection{Metodología}

\subsubsection{Tratamiento térmico del inóculo.}

Para la selección de los microorganismos productores de $\mathrm{H}_{2}$ el inóculo (proveniente de un reactor 
metanogénico de $5 \mathrm{~L}$ inoculado con lodos anaerobios de la planta de tratamiento de aguas residuales de la UAM-I) fue sometido a tratamiento térmico, para lo cual se probaron dos métodos: baño maría a $90^{\circ} \mathrm{C}$ por 30 minutos, que es un método reportado por Lee et al. (2010); y, la aplicación de radiación de microondas (potencia media) por 1.5 min, en intervalos de 30 s ( 30 s en microondas y 10 s agitación fuera del microondas). Se realizó un ensayo preliminar utilizando una dilución 1:1 del sustrato y $1 \%$ de $\mathrm{CH}$ para seleccionar el mejor tratamiento térmico, es decir, aquél con el que no se presentará la producción de metano.

\subsubsection{Sustrato y harina de cascarón de huevo $(\mathrm{CH})$}

Como sustrato se empleó una mezcla de verduras y cáscaras de frutas (jitomate, lechuga, espinacas, cáscaras de pepino y de plátano, además de chayote, manzana y papaya) provenientes de residuos de cocina que fueron molidas en una licuadora doméstica y se emplearon sin tamizar. La concentración de sólidos totales de la mezcla fue de $67 \mathrm{gST} \mathrm{kg}^{-1}$ de residuo y la de sólidos volátiles fue $62 \mathrm{gSVT}_{\mathrm{kg}}{ }^{-1}$ de residuo y $\mathrm{pH}$ de 5.3 .

Para la obtención de harina de $\mathrm{CH}$, se colectaron cascarones de huevo y se molieron en seco en una licuadora doméstica, posteriormente se tamizó la harina y el tamaño de partícula que se utilizó fue < $0.125 \mathrm{~mm}$.

\subsubsection{Diseño experimental}

El efecto de dos factores con sus respectivos niveles sobre la producción de hidrógeno fue evaluada en un diseño factorial completo: factor concentración del sustrato (con dos niveles: $33.2 \mathrm{gST} \mathrm{kg}^{-1}$ mezcla y $22.1 \mathrm{gST} \mathrm{kg}^{-1}$ mezcla) y factor concentración de harina de $\mathrm{CH}$ (con cuatro niveles: $0 \%, 1 \%$, $2 \%$ y $4 \%)$.

Posteriormente y con el mejor tratamiento seleccionado a partir de los ensayos planteados en el diseño 
experimental anterior, se probó un tratamiento adicional con la adición de los siguientes nutrientes administrados en el agua de dilución (en g L-1): $\left(\mathrm{NH}_{4}\right)_{2} \mathrm{PO}_{4}, 3.0 ; \mathrm{KH}_{2} \mathrm{PO}_{4}, 0.6 ; \mathrm{K}_{2} \mathrm{HPO}_{4}, 2.4$; $\mathrm{MgSO}_{4} \cdot 7 \mathrm{H}_{2} \mathrm{O}, 1.5 ; \mathrm{CaSO}_{4}, 0.15 ; \mathrm{y} \mathrm{FeSO}_{4}, 0.03$. Finalmente se preparó un tercer experimento con dos tratamientos, uno purgado con Ar y otro con vacío para determinar si había efecto positivo sobre la producción de $\mathrm{H}_{2}$ al emplear vacío como método de desgasificación del biogás producido.

\subsubsection{Producción de hidrógeno por fermentación oscura en lote.}

Todos los tratamientos se llevaron a cabo por triplicado en viales de $120 \mathrm{~mL}$ con un volumen de trabajo de $50 \mathrm{~mL}, 10 \%$ de inóculo, sin el ajuste inicial de $\mathrm{pH}$, incubación a $35^{\circ} \mathrm{C}$; mediante vacío se propició condiciones anaerobias, y se retiró el biogás producido de manera intermitente. Finalmente se llevó a cabo la recuperación de los efluentes de fermentación oscura centrifugando a 4000 rpm por 10 min el contenido de los viales para su utilización en los experimentos de fotofermentación.

\subsubsection{Producción de hidrógeno por fermentación oscura en reactor de $5 \mathrm{~L}$.}

Una vez establecidas las condiciones para realizar la fermentación oscura se llevó a cabo el proceso en un reactor de $5 \mathrm{~L}$, el cual fue incubado en baño maría a $35^{\circ} \mathrm{C}$ y mezclado con un agitador magnético a 120 rpm. El biogás producido fue colectado en bolsas tedlar y los DFE (denominados DFE-UAM) fueron recuperados por centrifugación y conservados en refrigeración $\left(5^{\circ} \mathrm{C}\right)$ para su utilización en los experimentos de fotofermentación del capítulo 6. 


\subsubsection{Producción de $\mathrm{H}_{2}$ por fotofermentación con DFE-UAM}

El primer ensayo que se llevó a cabo fue para seleccionar el pH inicial óptimo. Los pH iniciales probados fueron 6.0, 6.5 y 7.0. En este experimento se diluyó 7 veces el DFE-UAM para que quedara una concentración inicial de AGVs igual a la que se utilizó con los DFE-UPIBI.

Posteriormente se llevaron a cabo experimentos para seleccionar la concentración adecuada del DFE, para ello se probaron 3 diluciones: 10, 8 y 7 lo cual corresponde a 2.5, 3.0 y 3.5 gDQO L-1. Se colocó un control preparado con DFE-UPIBI a $2.5 \mathrm{gDQO} \mathrm{L}^{-1}$ que es la concentración que se utilizó en los experimentos anteriores (capítulos 2, 3 y 4). Como inóulo se utilizó el cultivo fotoheterótrofo IZT.

\subsubsection{Métodos analíticos}

Las determinaciones de producción de hidrógeno, AGVs, SV DQO y biomasa se llevaron a cabo como se describió en el capítulo 2.

\subsection{Resultados y discusión}

\subsubsection{Tratamiento térmico del inóculo}

El inóculo proveniente del digestor metanogénico presentó capacidad para la producción de $\mathrm{H}_{2}$ a partir de los residuos vegetales. Los resultados de los ensayos preliminares para seleccionar el mejor tratamiento térmico para el inóculo mostraron que los tratamientos en los que se usó el inóculo tratado en baño maría produjeron una mezcla de hidrógeno y metano, por lo que el calentamiento a $90^{\circ} \mathrm{C}$ por 30 min no fue suficiente para suprimir a las arqueas metanogénicas presentes en este inóculo.

En cambio, el tratamiento térmico con microondas resultó rápido y eficiente en la eliminación de la actividad de metanógenos, produciendo un biogás enriquecido de hidrógeno y sin rastros de metano, y enriqueció al inóculo de bacterias formadoras de esporas, las cuales pueden pertenecer al género 
Clostridium y Bacillus (Ntaikou et al., 2010; Redondas-Monteserrín, 2013). Faloye et al., (2014) aplicaron un método híbrido microondas por 2 min y alcalinizaron con $\mathrm{NaOH}$ hasta $\mathrm{pH} 11$, en este trabajo la aplicación sólo de tratamiento con microondas fue suficiente.

Lin et al., (2012) reportaron que durante el tratamiento térmico de lodos anaerobios aún persiste la presencia de algunos metanógenos resistentes al calor. Los tratamientos ácidos son muy eficientes en la remoción de metanógenos, pero tienen como desventajas que inducen baja producción de hidrógeno y remoción de sólidos ineficiente (Lin et al., 2012).

\subsubsection{Cascarón de huevo como amortiguador de pH.}

El cascarón de huevo se compone principalmente de $\mathrm{CaCO}_{3}(94 \%)$ (Stadelman, 2000), lo que lo hace un buen candidato como amortiguador de $\mathrm{pH}$ de bajo costo. En la figura 5.1 se presenta la producción acumulada de $\mathrm{H}_{2}$ por los tratamientos del experimento para seleccionar la concentración del sustrato y de $\mathrm{CH}$.

Como se puede observar en esta figura, la adición de $\mathrm{CH}$ favoreció significativamente la producción de hidrógeno; de hecho sólo en los tratamientos con $\mathrm{CH}$ hubo producción de hidrógeno. El pH inicial del tratamiento $\sin \mathrm{CH}$ fue 5.8 y para los tratamientos conteniendo $\mathrm{CH}$, los $\mathrm{pH}$ fueron de: 7.1 para el tratamiento con $1 \%$ de $\mathrm{CH}$ y 7.3 para los tratamientos con 2 y $4 \%$ de $\mathrm{CH}$. El pH final en todos los tratamientos con $\mathrm{CH}$ llegó a 5.5, el cual es el valor óptimo para la fermentación hidrogenogénica (Clark et al., 2012; Lin et al., 2012), en contraste a lo anterior, en el caso de los tratamientos $\sin \mathrm{CH}$, el pH final bajó hasta 4.3. Los valores de pH finales siempre fueron ácidos debido a la conversión de los carbohidratos contenidos en los residuos vegetales en ácidos orgánicos volátiles, proceso conocido como acidogénesis donde simultáneamente se produce $\mathrm{H}_{2}$ y ácidos (Ghimire et al., 2015; KumarKhanal, 2009; Redondas-Monteserrín, 2013). 


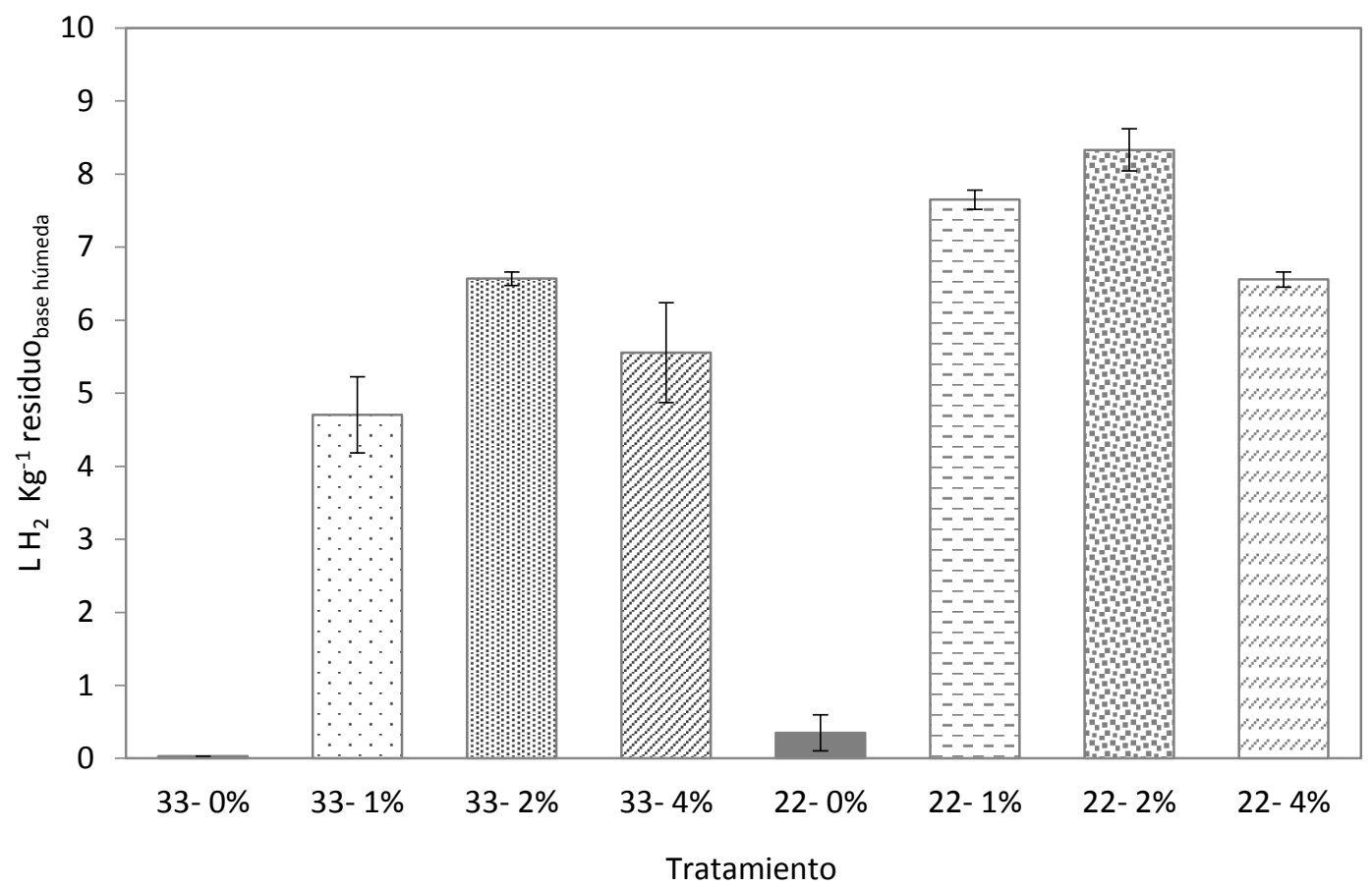

Figura 5.1. Producción acumulada de hidrógeno para los tratamientos con 33 y 22 gST, y $0,1,2$ y $4 \%$ de $\mathrm{CH}$.

Los resultados indican que el $\mathrm{CH}$ fue un buen amortiguador del pH en la fermentación y aunque el $\mathrm{CaCO}_{3}$ es muy poco soluble en agua, a medida que se fueron produciendo los $\mathrm{AGVs}$, la harina de $\mathrm{CH}$ se fue disolviendo en el medio y de esta manera se liberó el ión carbonato que actúa como amortiguador de $\mathrm{pH}$.

En los tratamientos sin $\mathrm{CH}$ la producción de $\mathrm{H}_{2}$ fue nula o muy baja, ya que que el pH para estos tratamientos bajó a un pH 4.3 al término del experimento con relación al valor de pH inicial que fue de 5.8. Ese valor de $\mathrm{pH}$ (4.3) es muy bajo para que la producción de $\mathrm{H}_{2}$ sea posible, ya que se produce la inhibición de la enzima hidrogenasa y la ruta metabólica de acidogénesis se detiene y comienza la producción de solventes. Durante la solventogénesis pueden producirse metanol, etanol, cetonas y $\mathrm{CO}_{2}$ (De Gioannis et al., 2013) dando como resultado una mezcla de AGVs y solventes. 
Como se puede apreciar de la Figura 5.1, la concentración óptima de $\mathrm{CH}$ para la producción de hidrógeno fue del $2 \%$ para ambas concentraciones de sustrato. Una concentración de $1 \%$ de $\mathrm{CH}$ fue insuficiente y 4\% de $\mathrm{CH}$ debió ser muy alto, posiblemente porque aumentó la concentración de sales a un nivel que, aunque no suprimió la producción de hidrógeno, si la afectó a la baja.

El tratamiento con una concentración de $22 \mathrm{~g}$ de ST alimentados $\mathrm{Kg}^{-1}$ de mezcla y con $2 \%$ de $\mathrm{CH}$ presentó la producción más alta de hidrógeno, $8.3 \mathrm{~L} \mathrm{H}_{2} \mathrm{~kg}^{-1}$ de residuo en base húmeda. Para efectos de comparación, esta producción equivale a $125 \mathrm{~mL} \mathrm{H}_{2} \mathrm{~g}^{-1}$ ST alimentados ó $134 \mathrm{~mL} \mathrm{H} \mathrm{H}^{-1}$ SVT alimentados o bien a $986 \mathrm{~mL} \mathrm{H}_{2} \mathrm{~g}^{-1}$ SVT removidos.

Estos rendimientos superan en gran medida los obtenidos por Choi \& Ahn (2014) (ver Tabla 5.1), quienes reportaron una producción de $\mathrm{H}_{2}$ de $13 \mathrm{~mL} \mathrm{H}_{2} \mathrm{~g}^{-1} \mathrm{SV}$ alimentado. Gómez et al. (2009), por su parte, reportaron producciones de $27-28 \mathrm{~mL} \mathrm{~g}^{-1} \mathrm{SV}$ alimentados, mientras que Kim et al. (2012), tienen la producción más alta reportada con $137 \mathrm{~mL} \mathrm{~g}^{-1}$ SV alimentados, seguidos por Zhu et al., 2008 con $112 \mathrm{~mL} \mathrm{H}_{2} \mathrm{~g}^{-1}$ SV alimentado.

Para todos los tratamientos se determinó la concentración final de ácido acético, propiónico y butírico, los valores se muestran en la Tabla 5.2. El ácido butírico se produjo en mayor proporción, seguido por el ácido acético y pequeñas cantidades de propiónico, lo cual indica que en el inóculo puede estar presente Clostridium butyricum debido a que la producción de ácido acético y butírico generalmente está asociada al metabolismo productor de hidrógeno (Beckers et al., 2012). Sin embargo, la formación de los ácidos acético y butírico puede ser influenciada por el pH, cuando el pH del medio alcanza un valor entre 4 y 6 la cantidad de ácido butírico es mayor que la de ácido acético, mientras que si el pH está entre 6.5 y 7 las cantidades de ácido acético y ácido butírico son semejantes (De Gioannis et al., 2013; Ghimire et al., 2015). 
Tabla 5.1. Producción de hidrógeno por fermentación oscura reportada en literatura.

\begin{tabular}{|c|c|c|}
\hline Sustrato & Producción de hidrógeno & Referencia \\
\hline Residuos de comida & $13 \mathrm{~mL} \mathrm{H}_{2} \mathrm{~g}^{-1} \mathrm{SV}$ alimentados & Choi \& Ahn, 2014 \\
\hline Paja de arroz & $24.8 \mathrm{~mL} \mathrm{H}_{2} \mathrm{~g}^{-1} \mathrm{ST}$ alimentados & Chen et al., 2012 \\
\hline Residuos de comida & $28 \mathrm{~mL} \mathrm{H}_{2} \mathrm{~g}^{-1} \mathrm{SV}$ alimentados & Gómez et al. 2009 \\
\hline Residuos de comida & $137 \mathrm{~mL} \mathrm{H}_{2} \mathrm{~g}^{-1}$ SV alimentados & Kim et al. 2012 \\
\hline Residuos de comida & $112 \mathrm{~mL} \mathrm{H}_{2} \mathrm{~g}^{-1} \mathrm{SV}$ alimentado & Zhu et al. 2008 \\
\hline Residuos de cafetería & $192 \mathrm{~mL} \mathrm{H}_{2} \mathrm{~g}^{-1} \mathrm{SV}$ removidos día-1 & Ramos et al. 2012 \\
\hline $\begin{array}{l}\text { Fracción orgánica de } \\
\text { residuos sólidos urbanos }\end{array}$ & $165-360 \mathrm{~mL} \mathrm{H}_{2} \mathrm{~g}^{-1} \mathrm{VS}$ removido & Valdez-Vazquez et al., 2005 \\
\hline $\begin{array}{c}\text { Residuos de frutas y } \\
\text { verduras }\end{array}$ & $\begin{array}{c}134 \mathrm{~mL} \mathrm{H}_{2} \mathrm{~g}^{-1} \text { SV alimentado ó } \\
986 \mathrm{~mL} \mathrm{H}_{2} \mathrm{~g}^{-1} \text { SV removidos }\end{array}$ & Este trabajo \\
\hline
\end{tabular}

Tabla 5.2. Concentración de ácidos grasos volátiles al final de la fermentación oscura.

\begin{tabular}{ccccccc}
\hline $\begin{array}{c}\text { Tratamiento } \\
\text { Dilución } \mathrm{CH}\end{array}$ & $\begin{array}{c}\text { Ácido acético } \\
\mathbf{( g / L )}\end{array}$ & $\begin{array}{c}\text { Ácido } \\
\text { propiónico } \\
(\mathbf{g} / \mathbf{L})\end{array}$ & $\begin{array}{c}\text { Ácido butírico } \\
\mathbf{( g / L )}\end{array}$ & $\begin{array}{c}\text { Total } \\
(\mathbf{g} / \mathbf{L})\end{array}$ & $\mathrm{pH}$ final \\
\hline $1: 1$ & $0 \%$ & 2.3 & 0.8 & 0.8 & 3.9 & 4.2 \\
$1: 1$ & $1 \%$ & 1.2 & 0.3 & 6.8 & 8.3 & 5.5 \\
$1: 1$ & $2 \%$ & 2.8 & 0.6 & 7.0 & 10.4 & 5.5 \\
$1: 1$ & $4 \%$ & 4.3 & 0.4 & 6.4 & 11.1 & 5.5 \\
$1: 2$ & $0 \%$ & 1.7 & 0.1 & 0.1 & 1.9 & 4.3 \\
$1: 2$ & $1 \%$ & 2.3 & 0.5 & 4.5 & 7.3 & 5.5 \\
$1: 2$ & $2 \%$ & 2.6 & 0.5 & 4.2 & 7.3 & 5.5 \\
$1: 2$ & $4 \%$ & 3.8 & 0.5 & 3.8 & 8.1 & 5.5 \\
\hline
\end{tabular}


Con respecto a la concentración de sustrato, en la Figura 5.1 se puede observar que hay mayor producción de $\mathrm{H}_{2}$ en los experimentos con menor concentración de sólidos. En estos experimentos también se encontró que la concentración máxima de hidrógeno en el biogás fue del 50\% (y el resto $\mathrm{CO}_{2}$ ) y la fermentación se mantuvo con producción de biogás por 72 horas.

Estos resultados son razonables si se considera que una alta concentración de sustrato puede inhibir el proceso de producción de hidrógeno debido a que al aumentar la cantidad de sustrato la producción de AGVs incrementa a niveles tales que son tóxicos para las bacterias. Esto se puede observar en la Tabla 5.2 en donde los tratamientos con dilución 1:1 alcanzaron concentraciones de ácido butírico de $7 \mathrm{~g} \mathrm{~L}^{-1} \mathrm{y}$ en los de dilución 1:2 solo $4.2 \mathrm{~g} \mathrm{~L}^{-1}$.

Para evitar el efecto inhibitorio que sobre las bacterias se podría originar por las altas concentraciones, se podría diluir más el sustrato, sin embargo no es deseable usar altas diluciones por los requerimientos de agua.

En cuanto a la remoción de sólidos volátiles se encontró que los resultados son equiparables en los dos niveles de concentración y los tres niveles ensayados de $\mathrm{CH}$, con un promedio alrededor del $37 \%$ (ver Figura 5.2). Resulta aparentemente contradictorio que aunque la producción de $\mathrm{H}_{2}$ en los tratamientos con $33 \mathrm{~g}$ ST no excede los valores alcanzados por los tratamientos con $22 \mathrm{~g}$ ST, presenta las mismas remociones de sólidos. Sin embargo, esto puede explicarse con base a que los tratamientos con dilución 1:1 produjeron más AGVs (ver Tabla 5.2).

También es interesante observar que en los tratamientos $\sin \mathrm{CH}$ no hubo producción de hidrógeno, sin embargo presentaron remoción de sólidos por la producción de $\mathrm{CO}_{2}$, AGVs y solventes. 


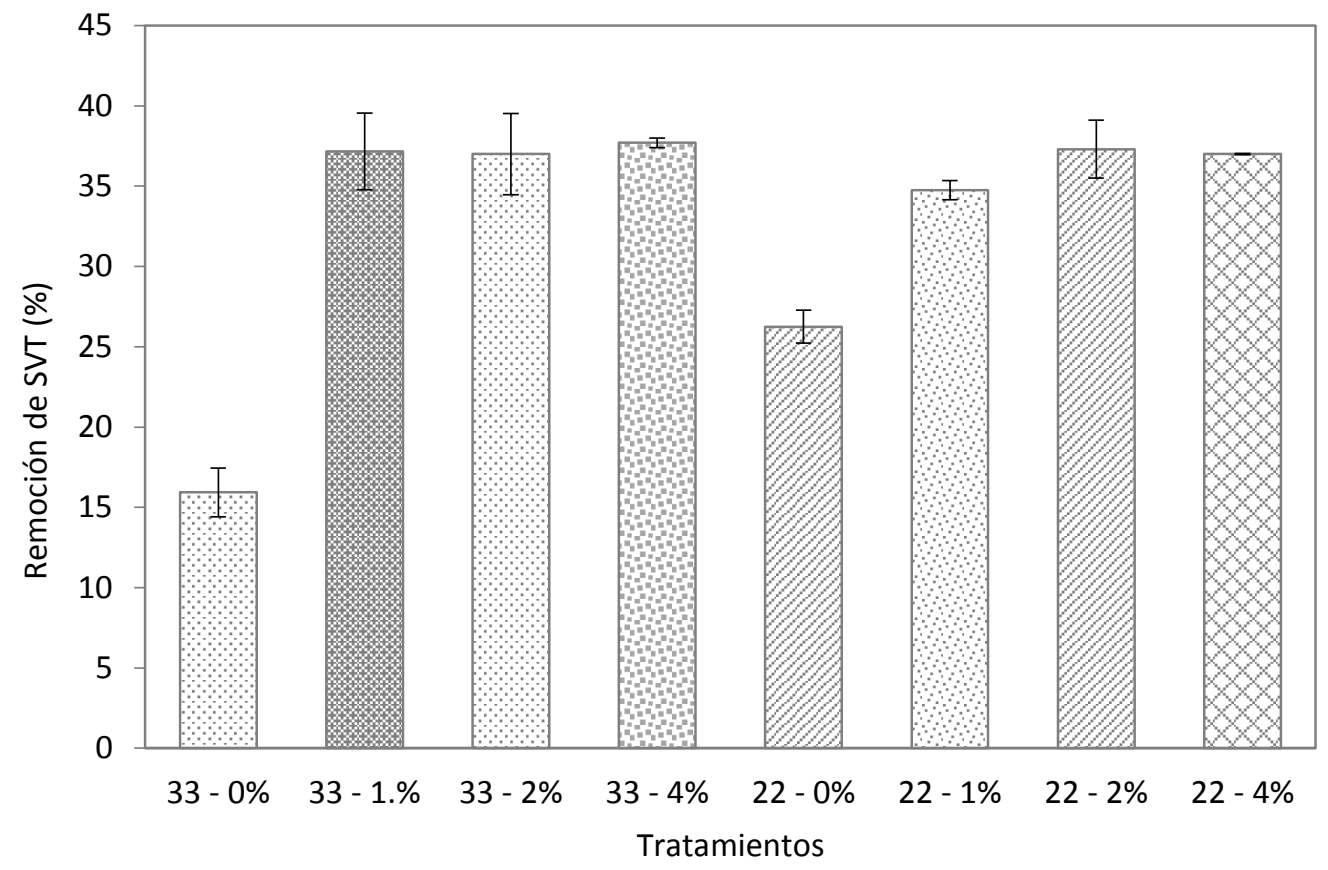

Figura 5.2. Remoción de sólidos volátiles totales en cada tratamiento.

\subsubsection{Suplementación con nutrientes}

En la mayor parte de los trabajos encontrados en la literatura se suplementa el sustrato (residuos de comida) con nutrientes químicos para la producción de hidrógeno, sin embargo no reportan algún tratamiento sin la suplementación de nutrientes (Lee et al., 2008; Ramos et al. 2012; Zhu et al. 2008, entre otros).

Este hecho hace necesario determinar si es necesario suplementar estos residuos con nutrientes para aumentar la producción de hidrógeno. Para este propósito, se prepararon dos tratamientos: uno con dilución $1: 2$ con $2 \%$ de $\mathrm{CH}$ con la adición de nutrientes mencionada en la parte experimental; $y$, un segundo en iguales condiciones sin la adición de nutrientes. Los dos tratamientos ensayados produjeron prácticamente la misma cantidad de hidrógeno $\left(8.9 \pm 0.5\right.$ y $9.1 \pm 0.2 \mathrm{~L} \mathrm{H}_{2} \mathrm{~kg}^{-1}$ residuObase húmeda, respectivamente), es decir, la adición de nutrientes no mejora la producción de hidrógeno. Al parecer los residuos de frutas y verduras que se emplearon, cuentan con los nutrientes necesarios 
para que las bacterias productoras de hidrógeno logren un nivel de actividad adecuado y el cascarón de huevo aportó la alcalinidad necesaria para el proceso.

\subsubsection{Producción de hidrógeno a presión reducida.}

El método más empleado para bajar la $\mathrm{PpH}_{2}$ en fermentación oscura es el purgado del espacio de cabeza del reactor con nitrógeno $0 \mathrm{CO}_{2}$, sin embargo esto hace más difícil la purificación del hidrógeno producido y encarece el proceso, por ello en todos los tratamientos se usó presión reducida para propiciar condiciones anaerobias y retirar el hidrógeno producido.

Otra ventaja de emplear vacío y mantener la presión del reactor por debajo de la presión atmosférica es que se puede tener un efecto positivo en los rendimientos de producción de hidrógeno. Una $\mathrm{PpH}_{2}$ baja en el espacio de cabeza de los reactores facilita la transferencia de masa del hidrógeno de la fase de líquido a la fase gaseosa (Clark et al., 2012; Mandal et al., 2006). Algunos trabajos han demostrado que la reducción de la $\mathrm{PpH}_{2}$ durante la fermentación oscura permite mejorar la producción de hidrógeno (Ghimire et al., 2015). Becker et al. (2012) observaron un aumento en los rendimientos del 7\% al mantener la presión del reactor por debajo de la presión atmosférica. En este trabajo, se observó una mejora del $11 \%$ en la producción de $\mathrm{H}_{2}$ en el experimento que se hizo para determinar el efecto positivo sobre la producción de $\mathrm{H}_{2}$ al emplear vacío como método de desgasificación del biogás producido.

\subsubsection{Producción de hidrógeno por fermentación oscura en reactor de $5 \mathrm{~L}$.}

Una vez establecidas las condiciones para realizar la fermentación oscura (dilución 1:2, 10\% de inóculo, tratamiento con microondas del inóculo, 2\% de $\mathrm{CH}$ y sin la adición de nutrientes) se llevó a cabo el proceso en un reactor de $5 \mathrm{~L}$ (Figura 5.3). El proceso se hizo en repetidas ocasiones para la 
obtención de un volumen de DFE suficiente para la operación del proceso de fotofermentación en reactor que se describirá en el capítulo 6. La producción de hidrógeno varió entre 6.3 y $8.8 \mathrm{~L} \mathrm{H}_{2} \mathrm{~kg}^{-1}$ residuobase húmeda, la composición de AGVs se mantuvo, en mayor proporción ácido butírico seguida del ácido acético y en pequeñas cantidades ácido propiónico. La remoción de sólidos también fue similar a las obtenidas en viales de $120 \mathrm{~mL}(32-40 \%)$.

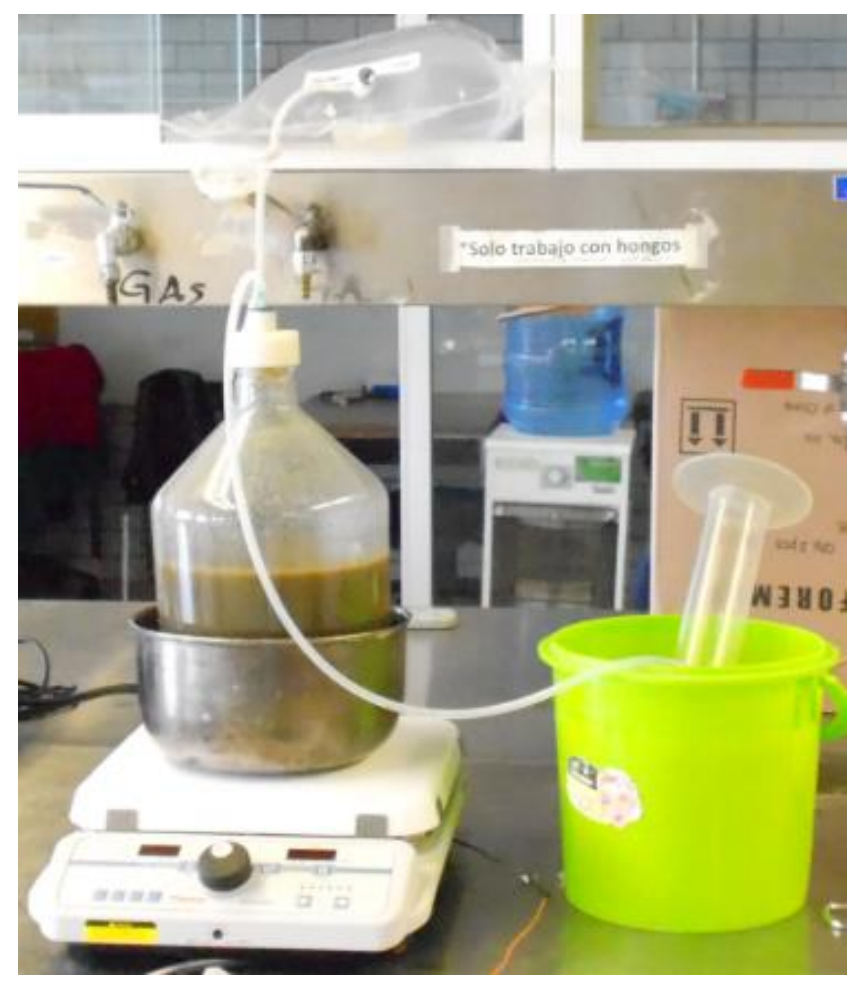

Figura 5.3. Fermentación oscura en reactor de $5 \mathrm{~L}$.

\subsection{Resultados para las pruebas de fotofermentación con DFE-UAM.}

\subsubsection{Caracterización de los DFE-UAM}

En la Tabla 5.3 se presenta la caracterización de los DFE-UAM que se emplearon para estas pruebas de producción de $\mathrm{H}_{2}$. En esa tabla se puede ver que la concentración de AGVs y DQO son menores que los DFE-UPIBI (ver tabla 1 del capítulo 2), lo cual se puede deber a que para los DFE-UAM se emplearon sólo cáscaras de frutas y en el caso de los DFE-UPIBI se utilizaron frutos completos, como 
consecuencia hubo mayor concentración de carbohidratos para la producción de AGVs y mayor cantidad de pulpa suspendida lo cual se refleja en una concentración más alta de sólidos y DQO.

Tabla 5.3. Composición de los DFE-UAM

\begin{tabular}{lr}
\hline Componente & \multicolumn{1}{c}{ Concentration } \\
\hline Ácido butírico & $4.2 \pm 0.35\left(\mathrm{~g} \mathrm{~L}^{-1}\right)$ \\
Ácido propiónico & $0.48 \pm 0.21\left(\mathrm{~g} \mathrm{~L}^{-1}\right)$ \\
Ácido acético & $2.64 \pm 0.18\left(\mathrm{~g} \mathrm{~L}^{-1}\right)$ \\
$\mathrm{NH}_{4}{ }^{+}$ & $175 \pm 32.5\left(\mathrm{mg} \mathrm{L}^{-1}\right)$ \\
$\mathrm{TOC}$ & $290.6 \pm 3.98\left(\mathrm{mg} \mathrm{L}^{-1}\right)$ \\
$\mathrm{TN}$ & $40.11 \pm 0.55\left(\mathrm{mg} \mathrm{L}^{-1}\right)$ \\
$\mathrm{C} / \mathrm{N}$ & 7.3 \\
$\mathrm{DQO}$ & $24 \pm 1\left(\mathrm{~g} \mathrm{~L}^{-1}\right)$ \\
SST & $110 \pm 12\left(\mathrm{mg} \mathrm{L}^{-1}\right)$ \\
SSV $\quad 98 \pm 13\left(\mathrm{mg} \mathrm{L}^{-1}\right)$ \\
\hline \multicolumn{2}{c}{${ }^{*} \mathrm{TOC}=$ carbono orgánico total, TN: nitrógeno total }
\end{tabular}

\subsubsection{Producción de hidrógeno}

En la figura 5.4 se presenta la Pacum $\mathrm{H}_{2}$ para los tratamientos con DFE-UAM a diferentes $\mathrm{pH}$ iniciales. Los tratamientos de este experimento y al igual que se hizo con los DFE- UPIBI fueron inicialmente suplementados con buffer de fosfatos para que quedara una concentración inicial de $22 \mathrm{mM}$ y con bicarbonato (250 mg L-1), sin embargo al adicionar el buffer de fosfatos el medio se tornó lechoso por la formación de un precipitado blanco el cual probablemente corresponde a un compuesto llamado hidroxiapatita formado por calcio y fosfato $\left(\mathrm{Ca}_{5}\left(\mathrm{PO}_{4}\right)_{3}(\mathrm{OH})\right)$. Se volvió a preparar el experimento sólo con el buffer de fosfatos sin la adición de bicarbonato, pero nuevamente se formó el precipitado. Esto indica que el DFE- UAM contiene carbonato de calcio (alcalinidad) residual proveniente del cascarón de huevo que se empleó en la fermentación oscura. Dado estas observaciones el DFE- UAM no fue suplementado con bicarbonato y buffer de fosfatos, lo cual representó una ventaja para el proceso, 
pues el cascarón de huevo que se empleó en la fermentación oscura no solo permitió amortiguar la caída de pH durante la fermentación oscura, sino también evitó el uso de buffer y la suplementación con bicarbonato para la fotofermentación. En la figura 5.4 se puede observar que con pH de 6 se tuvo una Pacum $\mathrm{H}_{2} 2.7$ veces más alta que con $\mathrm{pH} 7$ que fue el pH que se empleó con los DFE-UPIBI. Para ajustar el pH del tratamiento pH-6 se gastaron $8 \mathrm{mg}$ de $\mathrm{NaOH}$; para ajustar el $\mathrm{pH}$ a 6.5, se emplearon 24 mg y; para obtener un pH inicial de 7 se requirieron 36 mg. Al adicionar más $\mathrm{NaOH}$ la concentración de sales aumentó y afectó de manera negativa la producción de hidrógeno. Al parecer el DFE-UAM contiene suficiente alcalinidad para las BPNS y la adicción de $\mathrm{NaOH}$ no es necesaria.

Una vez establecido el pH inicial, se preparó un experimento para probar otras concentraciones del DFE-UAM. En el experimento anterior se utilizó una dilución 7 que permitió tener una concentración inicial de AGVs igual a la que se tuvo con la dilución 12 del DFE-UPIBI, sin embargo la concentración de DQO que engloba al resto de la materia orgánica contenida en los DFE-UAM fue de $3.5 \mathrm{~g} \mathrm{DQO} \mathrm{L-}$ ${ }^{1}$ la cual es 1 unidad más alta que en los tratamientos con DFE-UPIBI, así que se probaron 3 diluciones: 10, 8 y 7 que corresponden a 2.5, 3.0 y $3.5 \mathrm{gDQO} \mathrm{L-1} \mathrm{y} \mathrm{se} \mathrm{colocó} \mathrm{un} \mathrm{control} \mathrm{con} \mathrm{DFE-UPIBI} \mathrm{a} 2.5$ gDQO L-1. 


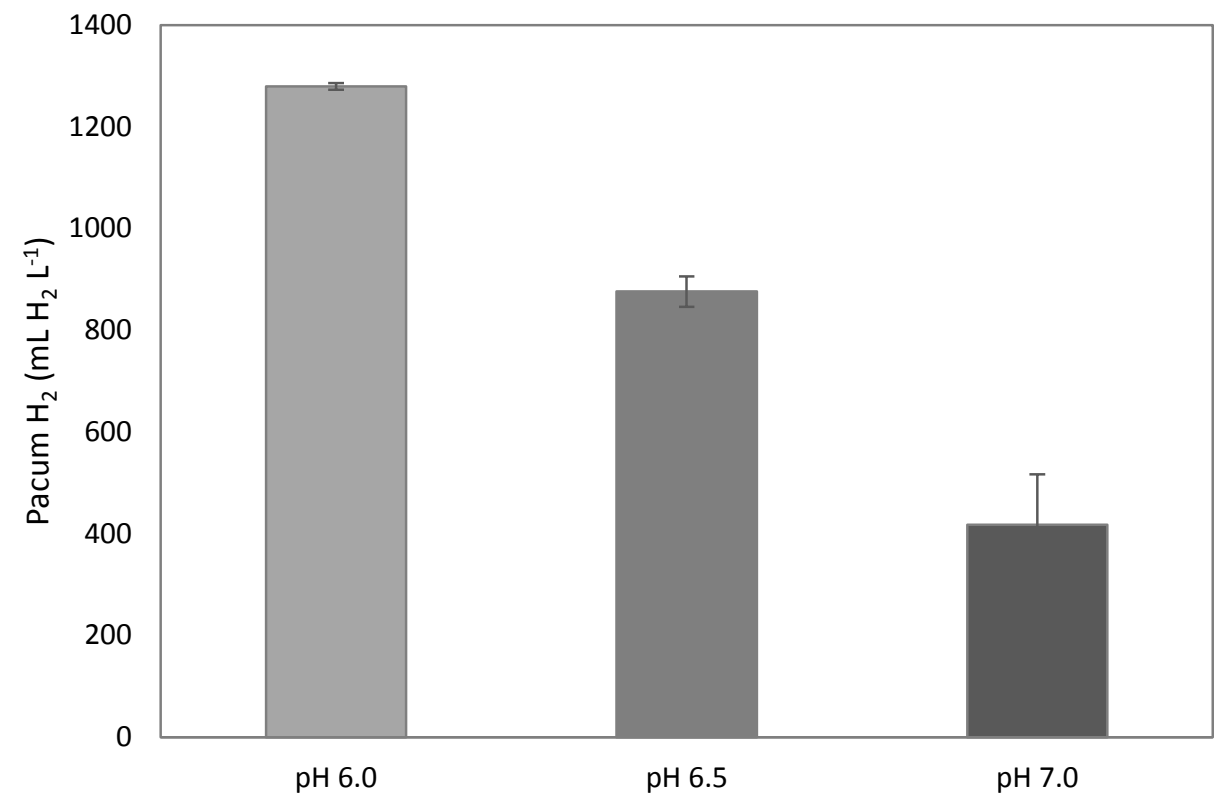

Figura 5.4. Pacum $\mathrm{H}_{2}$ por los tratamientos con $\mathrm{pH}$ inicial $6,6.5$ y 7 utilizando DFE-UAM.

En la figura 5.5 se presenta la Pacum $\mathrm{H}_{2}$ para los tratamientos con diferentes concentraciones del DFE-UAM y el control con DFE-UPIBI. Conforme la concentración disminuyó la Paccum $\mathrm{H}_{2}$ aumentó, al haber mayor concentración de sustrato, mayor Paccum $\mathrm{H}_{2}$ y producción de biomasa (ver figura 5.6), sin embargo ya no se probaron concentraciones menores del sustrato para evitar mayor desarrollo de biomasa y la obstaculización de la penetración de la luz dentro del cultivo por alta concentración de sólidos. Con la dilución 7 (3.5g DQO) del DFE-UAM se obtuvo una Pacum $\mathrm{H}_{2}$ similar a la del DFEUPIBI en este experimento y en los de los capítulos 2 y 3. 


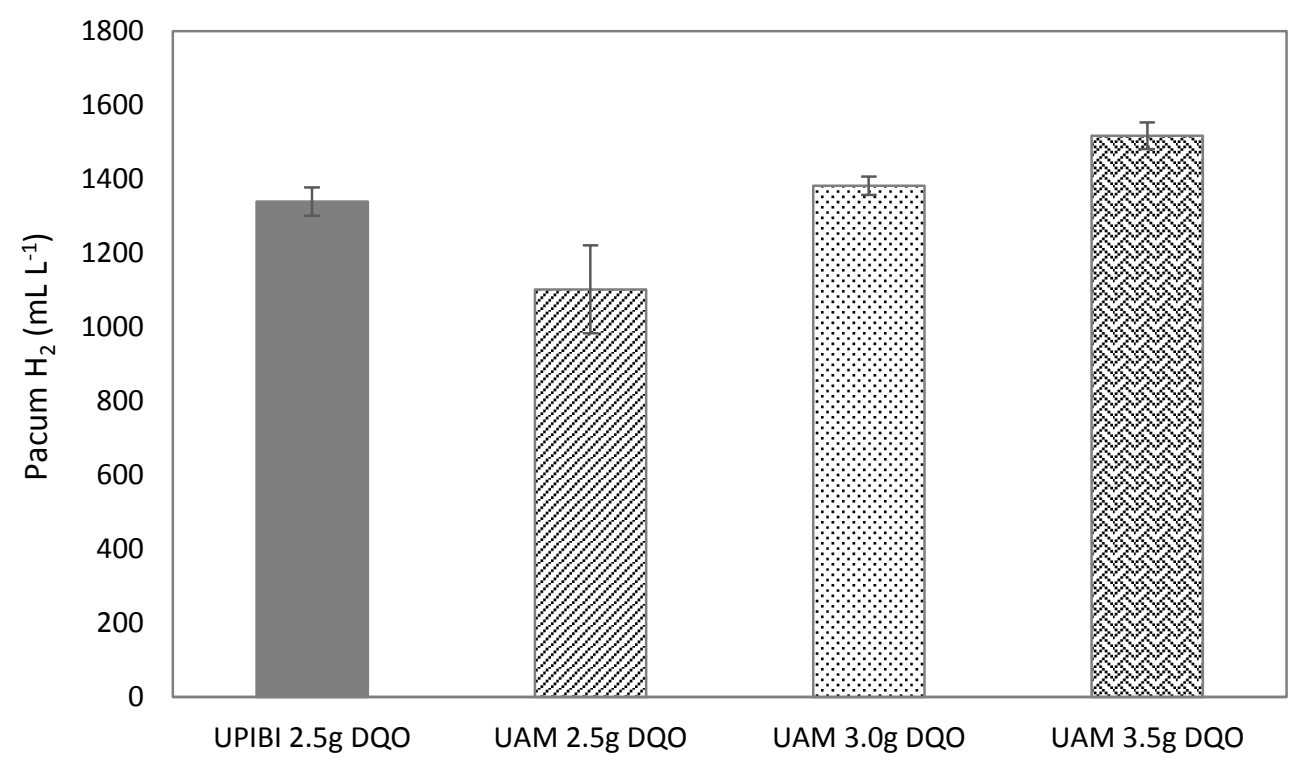

Figura 5.5. Producción acumulada de hidrógeno para el experimento de fotofermentación con diferentes concentraciones de DQO del DFE-UAM.

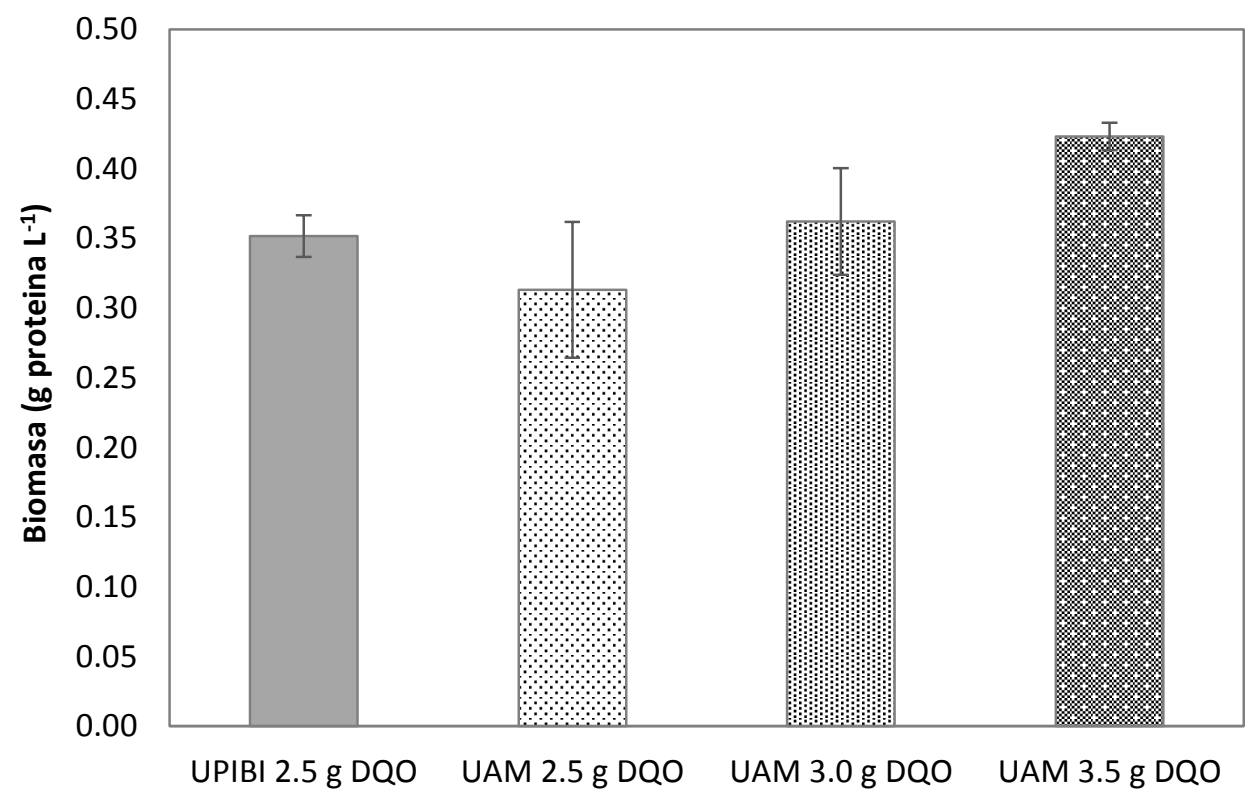

Figura 5.6. Concentración de biomasa para el experimento de fotofermentación con diferentes concentraciones del DFE-UAM. 
La remoción de DQO para todos los tratamientos fue superior al 80\% (ver figura 5.7). La remoción de DQO para el tratamiento con concentración $2.5 \mathrm{~g}$ DQO alcanzó el $90 \%$ y para el tratamiento con 3.5 g DQO fue del $82 \%$.

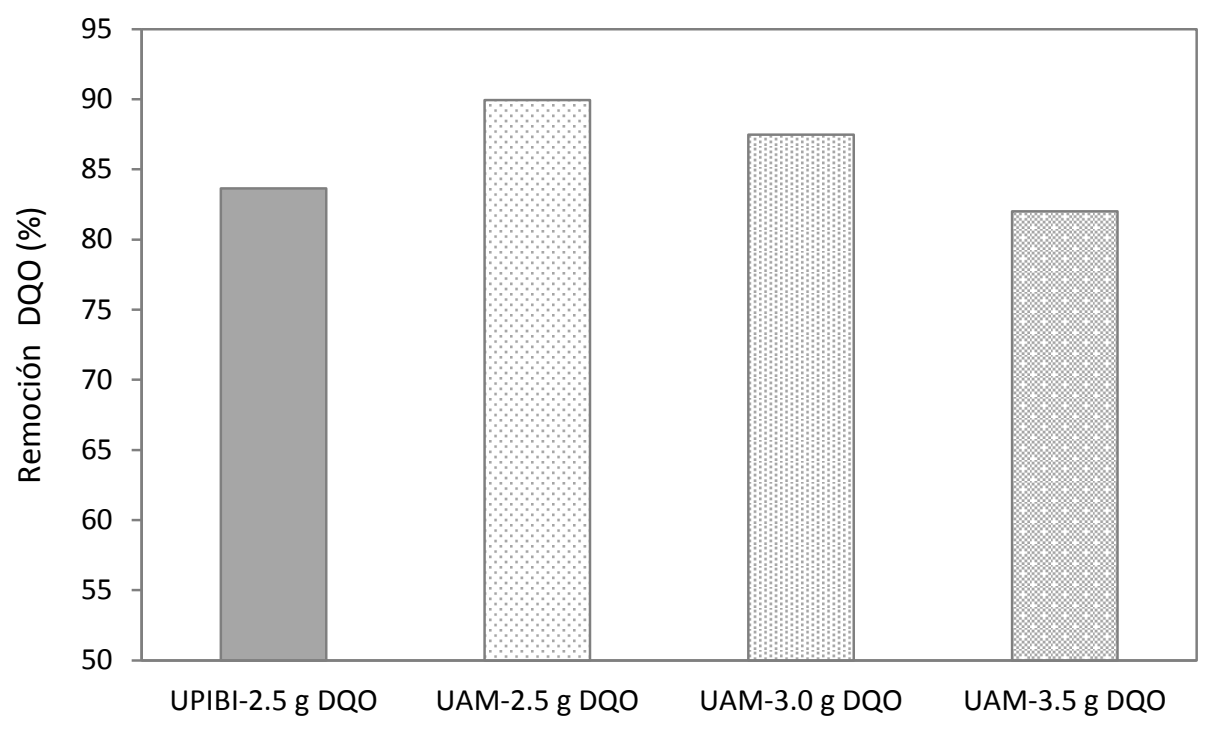

Figura 5.7. Remoción de DQO para el experimento con diferentes concentraciones del DFE-UAM

\subsection{Conclusiones}

La conclusión más sobresaliente de esta actividad es que se pueden obtener rendimientos de $\mathrm{H}_{2}$ similares e incluso mejores a los reportados en literatura utilizando residuos vegetales como sustrato sin la utilización de sustancias químicas para regular el pH y sin la adición de nutrientes. Puesto que, por un lado, el cascarón de huevo funcionó adecuadamente como amortiguador de pH. En los sistemas de fermentación oscura el alto consumo de alcalinidad externa para mantener el pH en el rango deseado es crucial. Cuando el sustrato está formado a base residuos ricos en carbohidratos, el suplemento de alcalinidad pueden constituir los costos operacionales más altos (RedondasMonteserín, 2013). En muchos de los trabajos reportados en la literatura se emplean fosfatos 0 
carbonatos grado reactivo para preparar amortiguadores y evitar grandes variaciones de $\mathrm{pH}$ durante la fermentación oscura, sin embargo esto encarece el proceso.

Por otro lado, se observó que el sustrato tiene los nutrientes suficientes para permitir el desarrollo de las bacterias productoras de hidrógeno y no es necesario la adición de complementos químicos.

La utilización de vacío para desgasificar los reactores además de facilitar la purificación del hidrógeno también contribuyó a aumentar la producción de hidrógeno.

Adicionalmente, en los experimentos de fermentación oscura en reactor de $5 \mathrm{~L}$ la producción de hidrógeno se mantuvo cerca de lo obtenido en viales de $120 \mathrm{~mL}$.

En cuanto a los ensayos de producción de hidrógeno por fotofermentación utilizando los DFE-UAM, se observó que estos tienen suficiente alcalinidad, proveniente del cascarón de huevo utilizado en la fermentación oscura, lo cual permite utilizarlos para esta etapa sin la adición de buffer. Esto fue un resultado muy alentador debido al ahorro que genera en este proceso.

Finalmente, se logró reproducir con éxito la fotofermentación empleando DFE-UAM, de forma que se obtuvieron los parámetros adecuados para el proceso que se describe en el siguiente capítulo. 


\section{CAPÍTULO 6}

\section{CONSTRUCCIÓN, ARRANQUE Y OPERACIÓN DE UN FOTOBIORREACTOR DE 18 LITROS PARA LA PRODUCCIÓN DE HIDRÓGENO.}

\subsection{Introducción}

El diseño, construcción y operación de los fotobiorreactores son factores críticos para lograr la producción de hidrógeno por fotofermentación a escala piloto e industrial. Los fotobiorreactores para la producción de hidrógeno con BPNS deben ser sistemas cerrados, debido a la necesidad de mantener condiciones anaerobias y evitar la dispersión del hidrógeno producido (Adessi \& De Philippis, 2014). Para la construcción de fotobiorreactores se deben tomar en cuenta factores que afectan su desempeño tales como: configuración, relación área volumen alta para permitir una buena distribución de la luz dentro del cultivo, transparencia y durabilidad del material de construcción, control de temperatura, sistema de agitación para permitir a las células ser iluminadas uniformemente, además de un sistema para remover el $\mathrm{H}_{2}$ producido. 
Dentro de las principales configuraciones de fotobiorreactores que se han empleado para la producción de $\mathrm{H}_{2}$ están los tipos: fermentador, tubulares y planos con sus respectivas variaciones, ver figura 6.1 .
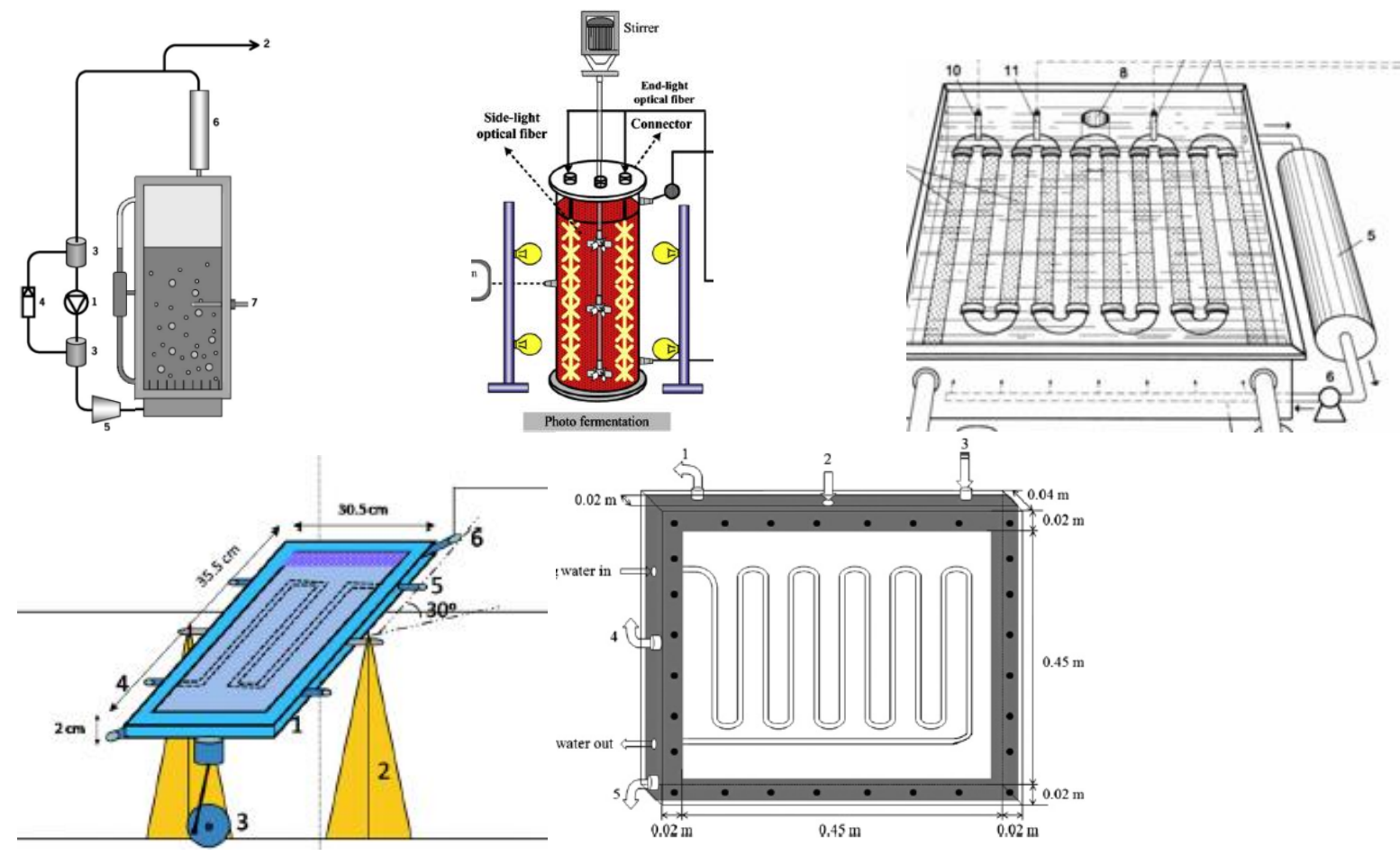

Figura 6.1. Fotobiorreactores empleados para la producción de hidrógeno (Hoekema et al. (2002), Chen et al. (2008), Carlozzi \& Sacchi (2001) Gilbert et al. (2011), Androga et al. (2011).

Los fotobiorreactores tipo fermentador generalmente son empleados para estudios de optimización a pequeña escala, pero su escalamiento a grandes volúmenes se ve limitado por la baja relación área/volumen que permite su configuración (Dasgupta et al., 2010). Se han elaborado reactores iluminados internamente a través de fibras ópticas como el diseño propuesto por Chen et al. (2008), sin embargo la utilización de fibras ópticas pueden encarecer el costo de los reactores.

Los fotobiorreactores tubulares consisten de tubos transparentes de 3 a $6 \mathrm{~cm}$ de diámetro que pueden ser dispuestos en forma horizontal, con una inclinación de $10^{\circ} \mathrm{a} 30^{\circ} \mathrm{o}$ en forma vertical (Akkerman et 
al., 2002; Adessi \& De Philippis, 2014). Los reactores tubulares verticales consisten de una sola columna, el reactor airlift y la columna de burbujas caen dentro de esta categoría. Este tipo de reactores son eficientes para proveer $\mathrm{CO}_{2}$ y separar el $\mathrm{O}_{2}$ (condiciones deseables para algas). Sin embargo, para la producción de hidrógeno con BPNS es un desafío en cuanto a la agitación, ya que el burbujeo con gas inerte diluye el hidrógeno producido y al final es difícil hacer la separación (Dasgupta et al., 2010). En el caso de los reactores tubulares horizontales o inclinados la agitación es mecánica o neumática y el biogás es colectado en el extremo superior por medio de una unidad de desgasificación, esto impone un límite de longitud, entre más largo es el tubo, mayor es el tiempo de permanencia del hidrógeno en el interior del reactor, el cual puede ser captado por las hidrogenasas de las bacterias, disminuyendo así la producción de hidrógeno (Adessi \& De Philippis, 2014). Dentro de los inconvenientes de estos reactores es la dificultad para controlar la temperatura, limpiarlos y el área relativamente grande que requieren para su instalación, lo cual también afecta el costo del proceso (Chen et al., 2011; Gebicki et al., 2010).

Los reactores planos son configuraciones rectangulares transparentes con pocos centímetros de grosor y pueden colocarse verticalmente o inclinados (Adessi \& De Philippis, 2014). Este tipo de reactores son de especial interés debido a su alta relación área/volumen. Permiten una distribución uniforme de la luz y se caracterizan por tener una área de transferencia de gas abierta reduciendo así la necesidad de una unidad de desgasificación (Dasgupta et al., 2010). Para el escalamiento estos reactores ofrecen la posibilidad de un arreglo de placas colocadas en forma paralela a una distancia adecuada que también ayuda a regular la temperatura (Gebicki et al., 2010), además los reactores planos son fáciles de construir, modificar y limpiar, sin embargo están limitados por el bajo nivel de agitación (Adessi \& De Philippis, 2014; Chen et al., 2011; Gilbert et al., 2011).

Los fotobiorreactores tubulares y planos ya se han escalado hasta 80 - 100 L para la producción de hidrógeno, ver figura 6.2 . 

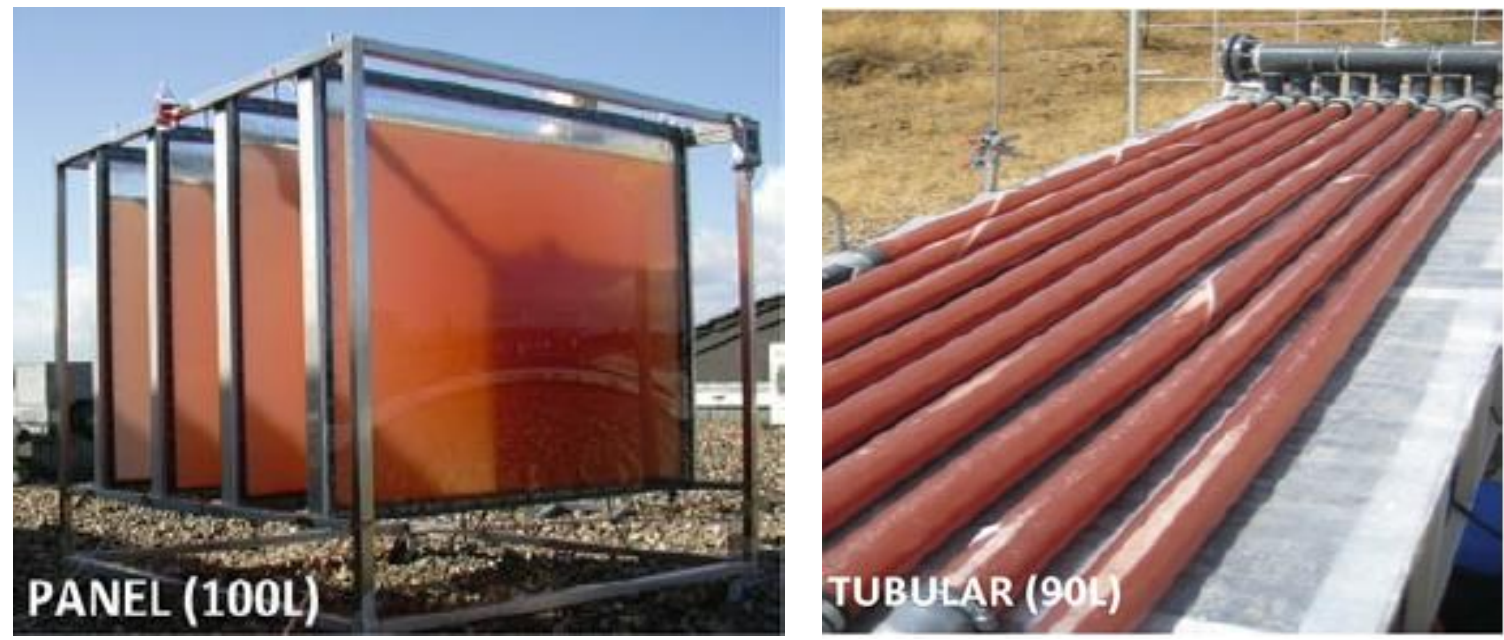

Figura 6.2. Reactor plano de 100L y reactor tubular de $90 \mathrm{~L}$ utilizado por Gebicki et al. (2010) y Boran et al. (2012) para la producción de $\mathrm{H}_{2}$.

En la primera parte de este capítulo se describe las consideraciones de diseño y la construcción del fotobiorreactor que se utilizó en este proyecto, mientras que en la segunda parte se detalla el arranque y las primeras pruebas de operación del fotobiorreactor construido.

\subsection{Factores de diseño para la construcción del fotobiorreactor}

\subsubsection{Configuración y material de construcción}

La configuración de reactor que se eligió para la producción de hidrógeno fue la de un reactor plano debido a que esta configuración permite una relación área/volumen alta cuando su grosor es mínimo (menos de $5 \mathrm{~cm}$ ) (Chen et al., 2011; Dasgupta et al., 2010), lo cual es deseable para permitir una buena distribución de la luz dentro del cultivo, además requieren poco espacio para su instalación y se han obtenido producciones de $\mathrm{H}_{2}$ más altas en este tipo de configuración; Gebicki et al., (2010) compararon la producción de hidrógeno en dos fotobiorreactores, uno tubular horizontal con $5^{\circ}$ de inclinación de $65 \mathrm{~L}$ y uno plano con 4 placas acomodadas paralelamente de forma vertical de $100 \mathrm{~L}$ 
bajo condiciones ambientales. Encontraron que la producción de hidrógeno en el reactor plano fue más alta, $295 \mathrm{~mL} \mathrm{H}_{2} \mathrm{~L}^{-1} \mathrm{~d}^{-1}$ contra $152 \mathrm{~mL} \mathrm{H}_{2} \mathrm{~L}^{-1} \mathrm{~d}^{-1}$ que se obtuvieron en el reactor tubular. También reportaron que mientras $8 \mathrm{~m}^{2}$ de superficie iluminada del reactor plano pueden ser instalados en $1 \mathrm{~m}^{2}$ de suelo, la superficie requerida para instalar $8 \mathrm{~m}^{2}$ del reactor tubular es de $8 \mathrm{~m}^{2}$ de suelo. Por otro lado, Oncel \& Kose (2014) también reportan producciones más altas de hidrógeno en un reactor plano que en uno tubular cuando emplearon Chlamydomonas reinhardtii para la producción de hidrógeno. Por otro lado, los reactores planos son más fáciles de construir y de fácil limpieza (Chen et al., 2011). Por lo mismo esta configuración fue la elegida para este trabajo.

Otro de los puntos clave a considerar fue la hermeticidad ya que, de acuerdo con los resultados del capítulo 2, el reactor debería operar a presión reducida y para ello un diseño con el menor número de uniones que pudiera asegurar mayor hermeticidad fue imprescindible.

Posteriormente se analizó el material de construcción. Uno de los primeros materiales considerados fue el vidrio, debido a su alta trasparencia (95\%), resistencia química y durabilidad, sin embargo es frágil, muy denso y los costos de instalación son muy altos (Dasgupta et al., 2010). En los talleres de vidrio locales que se consultaron sólo pueden trabajar con diseños tubulares pequeños de vidrio Pyrex y los costos del material y construcción son elevados, por lo que los siguientes materiales analizados fueron polimetil-metacrilato (o acrílico), policarbonato y PVC por su disponibilidad en placas de diferentes grosores en el mercado local, transparencia y baja permeabilidad a gases. Estos materiales se compararon en base a su costo, transparencia y durabilidad. En cuanto a costo el policarbonato es el más caro y en comparación con los otros dos materiales tiene baja permeabilidad a gases, el PVC es más caro que el acrílico y aunque soporta alta tensión y es resistente a ácidos y álcalis su transparencia es sólo del 80\%. El material seleccionado fue el acrílico debido a su alta transparencia (92\%), bajo costo, buena resistencia al impacto, resistencia a la concentración de los ácidos grasos presentes en el efluente de fermentación oscura, la variedad de grosor de las placas que 
comercialmente están disponibles y su baja permeabilidad a los gases en comparación con el policarbonato.

El siguiente paso fue elegir el grosor de las placas de acrílico que soportara operar bajo presión reducida, en la literatura se reportan grosores de 4 - 6mm (Eroglu et al., 2008; Gebicki et al., 2010; Gilbert et al., 2011), para este trabajo en un diseño preliminar pequeño se emplearon placas de $5 \mathrm{~mm}$, pero después de hacer vacío al reactor se observó la deformación de las placas, así que el grosor del acrílico empleado fue de $10 \mathrm{~mm}$ y las dimensiones del reactor fueron: $120 \mathrm{~cm}$ de alto, $56 \mathrm{~cm}$ de ancho y $2.7 \mathrm{~cm}$ de grosor lo que resultó en un volumen de $18 \mathrm{~L}$, entre las placas frontales se colocaron pequeños cubos de acrílico para evitar que las placas de contrajeran con el vacío. El grosor o profundidad del cultivo $(2.7 \mathrm{~cm})$ fue el mismo que se trabajó en las las botellas serológicas de $120 \mathrm{~mL}$ de los capítulos anteriores para asegurar la misma penetración de la luz incidente.

Las placas de acrílico no móviles se soldaron por fusión de las placas con cloroformo y se reforzaron con tornillos metálicos, las partes desmontables se fijaron por medio de tornillos metálicos de acero inoxidable cuidando que estos no estuvieran en contacto con el líquido. La tapa del reactor fue desmontable y contó con un "O"-ring, empaque plástico de neopreno y tornillos para sellar. En un extremo de la tapa se le adaptó un vacuómetro para medir la presión negativa y una entrada con septo de goma para desgasificar y tomar muestras de gas. A un costado del reactor y en la parte media se colocó un punto de muestreo con septo adicional para la toma de muestras líquidas. En la parte inferior de ambos costados del fotobiorreactor se colocó un puerto para la recirculación del medio. En la Figura 6.3 se muestra el reactor construido. 


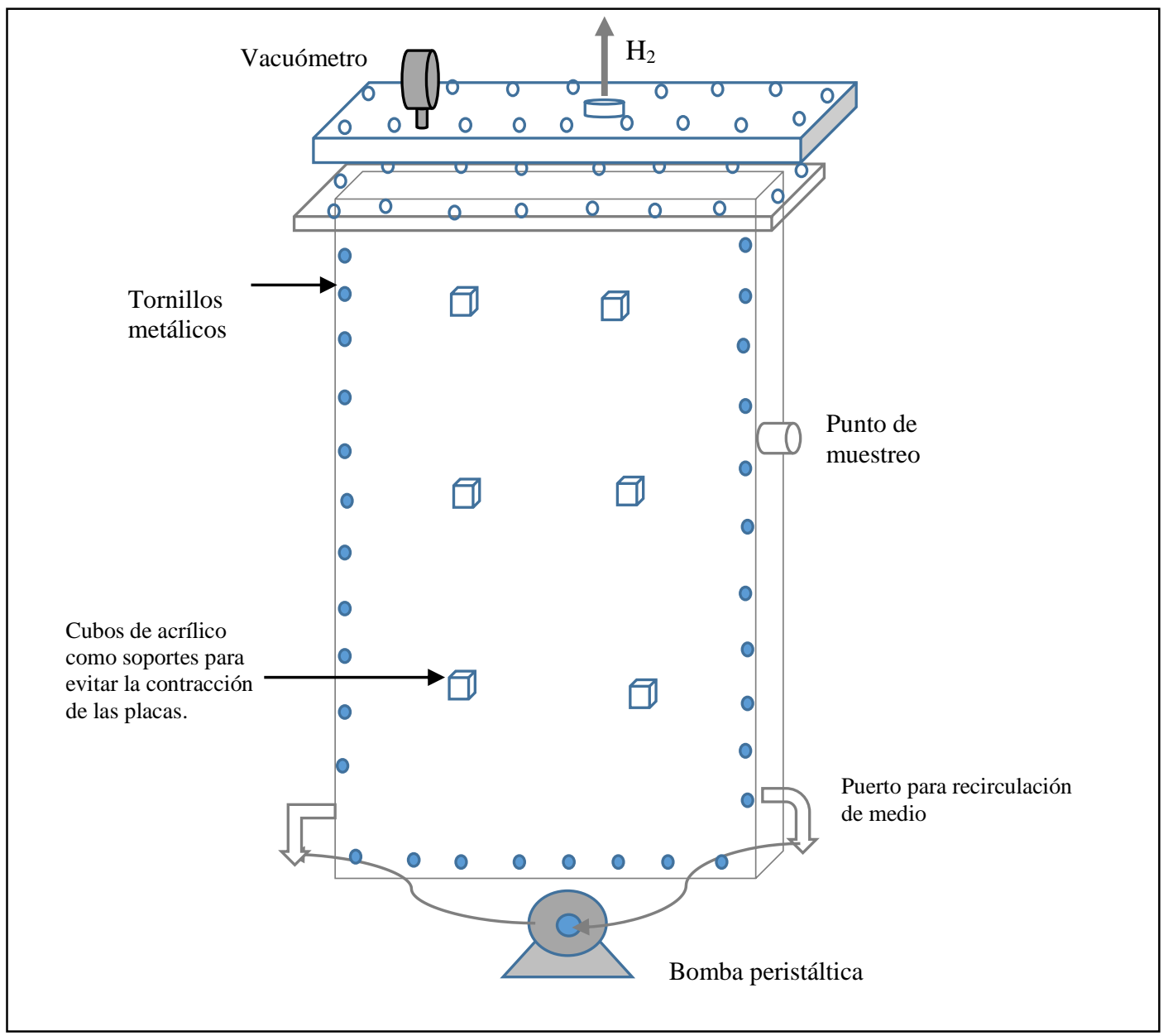

Figura 6.3. Esquema del fotobiorreactor plano construido para la producción de hidrógeno.

\subsubsection{Sistema de iluminación y control de temperatura.}

El sistema de iluminación es crucial para poder establecer una intensidad luminosa adecuada sobre el fotobiorreactor, como se mencionó en el capítulo 3 intensidades entre 3000 y 5000 lux dentro del reactor son las más adecuadas. De manera indirecta el sistema de iluminación ayudó a mantener la temperatura del medio entre 30 y $32^{\circ} \mathrm{C}$. A diferencia de la mayoría de los trabajos reportados en la literatura que emplean un sistema de calefacción como incubadora, placa de calentamiento 0 serpentín (Eroğlu et al., 2008; Gilbert et al., 2011; Xia et al., 2013) para mantener una temperatura 
adecuada, en este trabajo no fue necesario y se controló la temperatura sólo con el sistema de iluminación.

El reactor se iluminó sólo de una cara. Inicialmente se colocaron 4 lámparas fluorescentes y 9 lámparas de halógeno a una distancia de $30 \mathrm{~cm}$ del reactor para alcanzar la intensidad luminosa requerida, sin embargo y debido a que las lámparas de halógeno generan calor, la temperatura del medio superó los $40{ }^{\circ} \mathrm{C}$. Para evitar que la temperatura del medio subiera hasta esos valores se sustituyeron 6 lámparas de halógeno por 6 lámparas de LED de luz cálida, en la Figura 6.4 se puede ver el arreglo de lámparas. El gasto de energía por el uso únicamente de lámparas de tungsteno o halógeno sería de $40 \mathrm{kwh}$, pero si solo se emplearan lámparas de LED el gasto se reduciría a 5 kwh (gasto de energía calculado por Chen et al., 2011). Aunque en este sistema no se pudo reemplazar el total de lámparas de halógeno por LED debido a que las de halógeno son imprescindibles para calentar el medio, se puede considerar un ahorro de energía. 


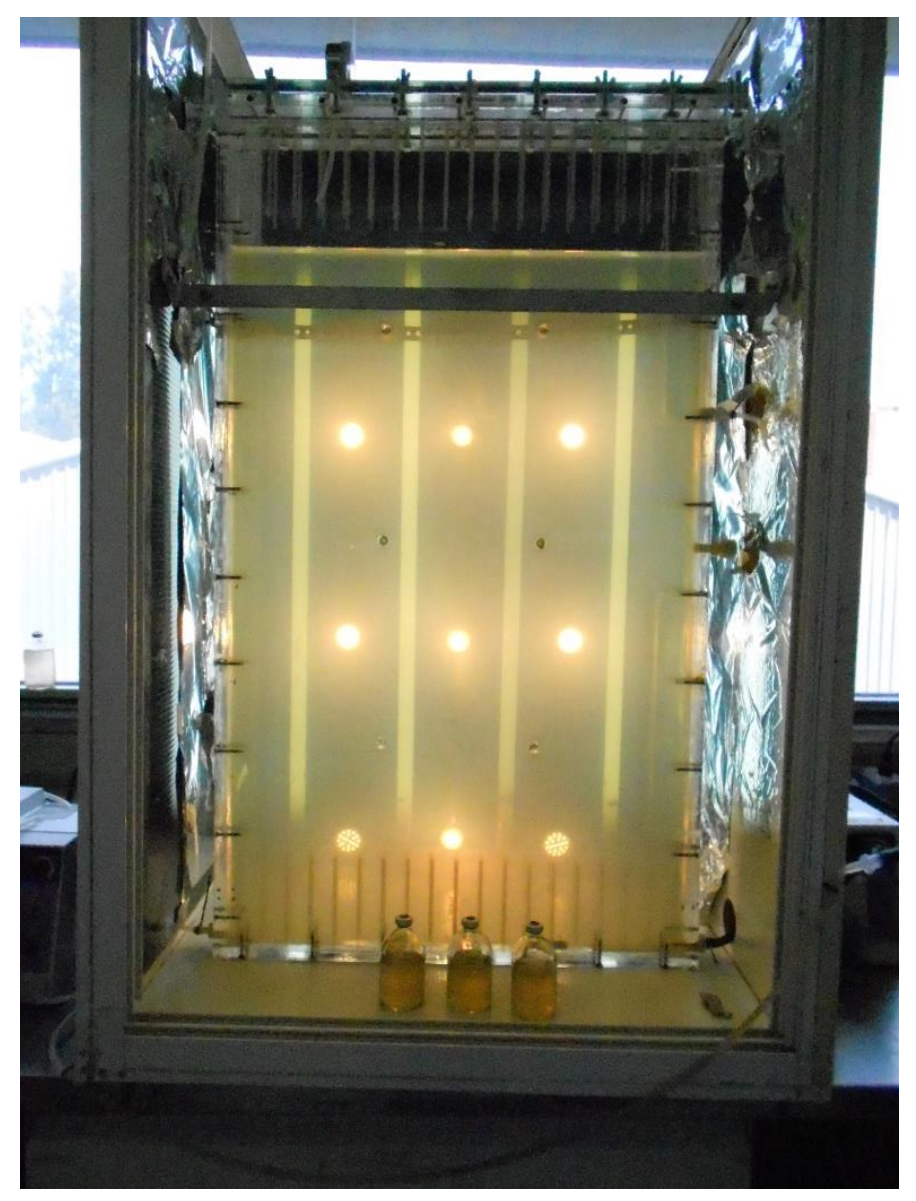

Figura 6.4. Arreglo de lámparas para el sistema de iluminación del fotobiorreactor.

\subsubsection{Agitación}

Los reactores planos a gran escala están limitados por el bajo nivel de agitación (Gilbert et al., 2011). Eroğlu et al. (2008) diseñaron un reactor solar tipo panel plano inclinado de $6.5 \mathrm{~L}$ con agitación por aspersión con argón, sin embargo su implementación a gran escala es poco factible por los altos costos de este gas. Hoekema et al. (2002) -construyeron un fotobiorreactor de panel plano agitado neumáticamente. En ese caso, durante los primeros experimentos, se dispersó gas argón a través del sistema para mezclado y se observó inhibición del crecimiento. Los resultados experimentales indicaron que la eliminación de dióxido de carbono en el líquido de cultivo causa inhibición del crecimiento, lo cual está de acuerdo con lo discutido en el capítulo 2, en cuanto que las BPNS 
requieren de dióxido de carbono durante su crecimiento en sustratos reducidos. Por otro lado, cuando recircularon el biogás producido se evitó que el dióxido de carbono fuera eliminado del sistema y esta forma de operación propició el crecimiento de Rhodopseudomonas sp. Sin embargo, el aumento en el tiempo de contacto gas-líquido puede afectar los rendimientos de producción de hidrógeno por la actividad de la hidrogenasa.

La agitación podría hacerse por recirculación de los gases generados siempre y cuando se empleen cultivos mutantes deficientes de hidrogenasa. El uso de bombas, agitación mecánica o neumática (tipo Airlift) para la recirculación causan fuerzas de cizalla sobre las células, lo cual puede causar lisis. Para solucionar este problema, Gilbert et al. (2011) diseñaron un reactor tipo panel plano con agitación por balanceo; en este caso, el tiempo de mezclado del reactor fue de $17 \mathrm{~s}$ a una agitación de 15 ciclos por minuto y la energía gastada fue muy baja, sin embargo este diseño es muy difícil de usarse en reactores a gran escala.

Considerando todo lo anterior, en el sistema usado en este trabajo, se escogió la recirculación del medio líquido a través de una bomba peristáltica. Debido a que la biomasa sedimenta en el fondo del reactor se colocaron dos salidas para manguera opuestas conectadas a la bomba peristáltica para recircular el medio y de esta manera circular/remover la biomasa del fondo y exponer el cultivo a la luz (ver Figura 6.5). Como se mencionó en el capítulo de antecedentes, las BPNS tienen un metabolismo muy flexible, puesto que pueden crecer de forma fotoheterótrofa y producir $\mathrm{H}_{2}$, pero si pasa lapsos prolongados de oscuridad, condición que puede presentarse cuando el cultivo sedimenta y no hay agitación, el cultivo puede cambiar el metabolismo y crecer en forma fermentativa y dejar de producir $\mathrm{H}_{2}$, de ahí es necesario asegurar un buen mezclado del cultivo. 


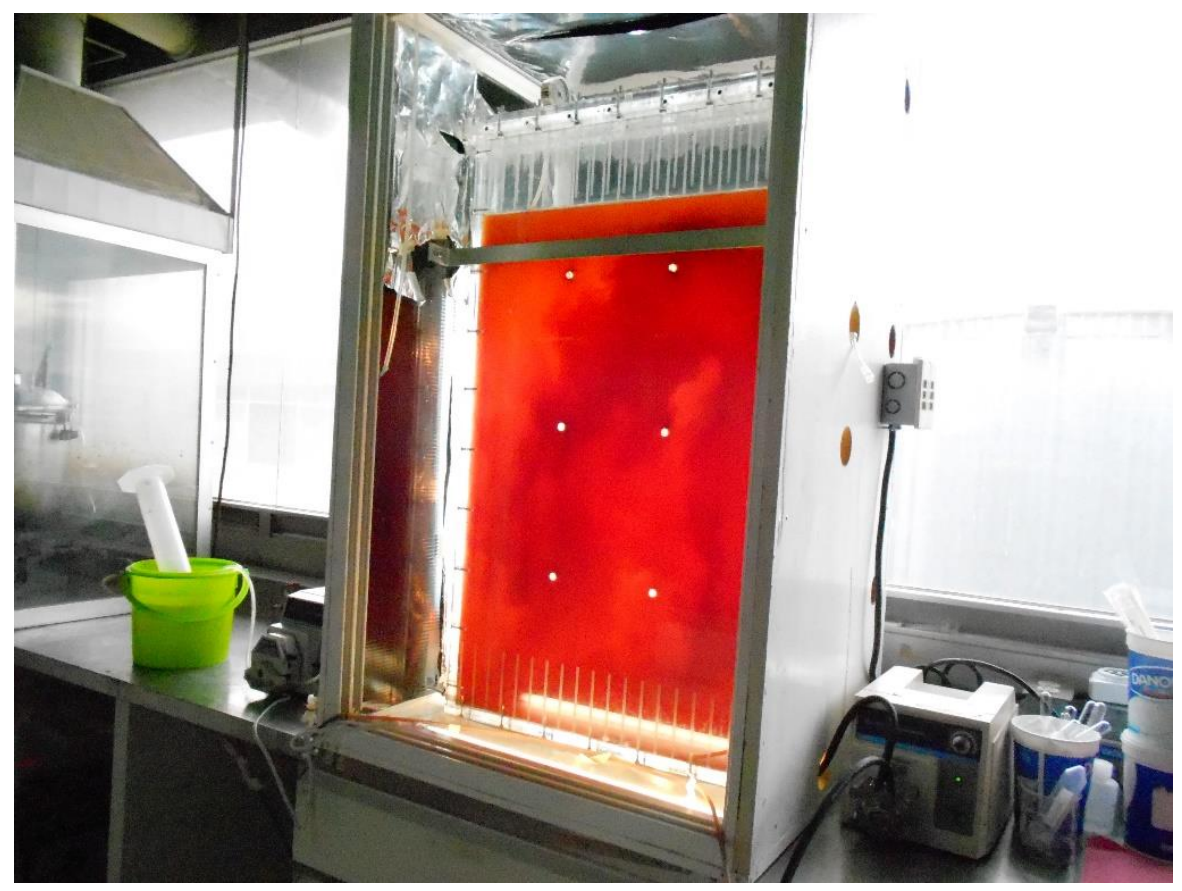

Figura 6.5. Sistema de recirculación del medio y colección del biogás producido.

Para lograr la suspensión completa del cultivo se probaron tres flujos de recirculación y se midió el tiempo en el que el cultivo se resuspendió completamente, el primer flujo que se probó fue de $350 \mathrm{~mL}$ $\mathrm{min}^{-1}$ con base a lo reportado por Gebicki et al. (2010), sin embargo este flujo no fue suficiente para re-suspender la biomasa, así que probaron flujos de 500 y $750 \mathrm{~mL} \mathrm{~min}^{-1}$, siendo éste último el adecuado, ya que se observó que en 6 min se logró suspender y mezclar completamente la biomasa. Con la finalidad de minimizar la formación de una película en las paredes internas del reactor se usó un sistema magnético dentro del reactor a base de un imán que al moverlo a través de las paredes permitiera despegar la biomasa (ver Figura 6.6). 


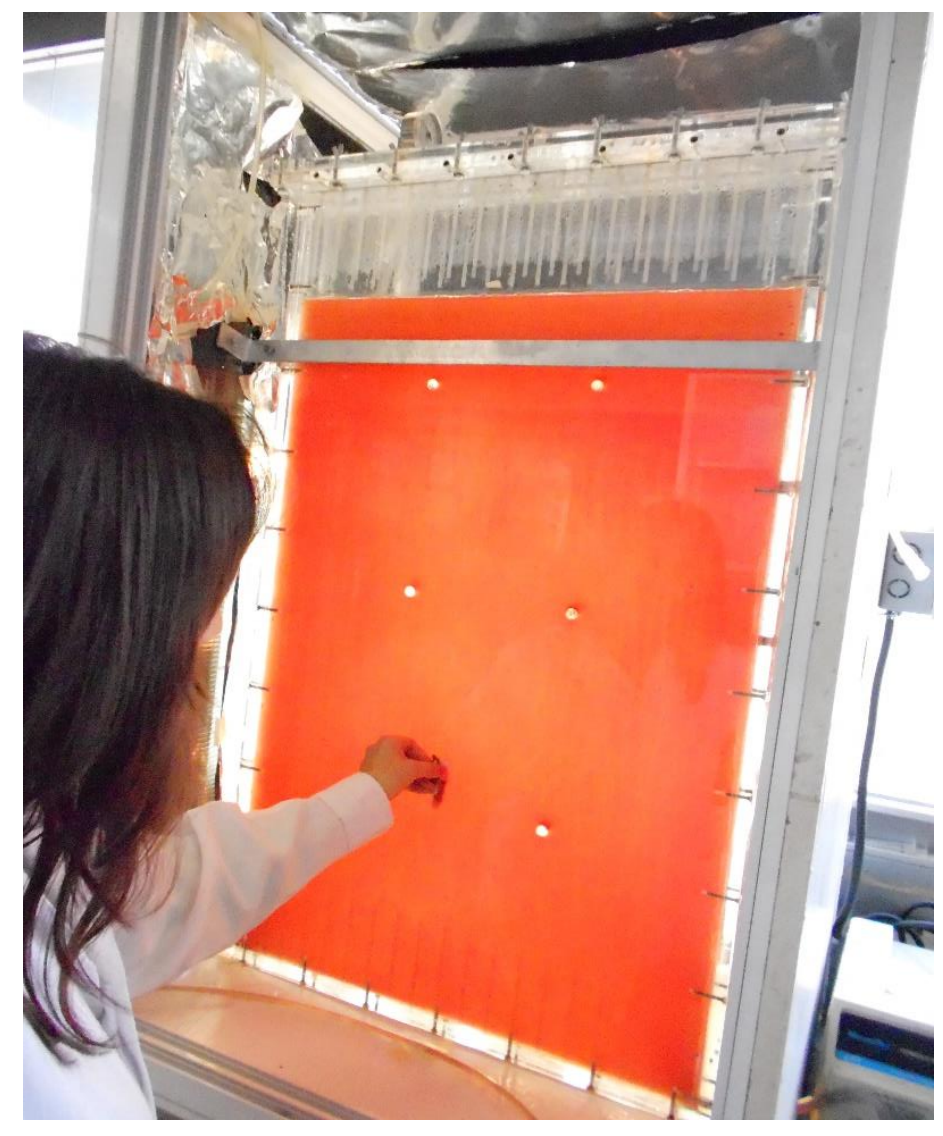

Figura 6.6. Remoción de la biomasa adherida a la pared de fotobiorreactor a través de un imán.

La agitación no solo ayudó a mantener el cultivo en suspensión, también ayudó a la desgasificación del medio permitiendo que el hidrógeno producido escapara del medio líquido y pasara al espacio gaseoso. Es importante asegurar que el tiempo de contacto del hidrógeno producido con el cultivo sea bajo debido a que se puede activar la capacidad consumidora de hidrógeno por la hidrogenasa presente en las BPNS. 


\subsubsection{Sistema de desgasificación}

Para la desgasificación y mantenimiento de presión negativa en el espacio de cabeza, el biogás se extrajo a través de una bomba peristáltica y éste fue colectado y cuantificado por el desplazamiento de agua en una probeta invertida (ver Figura 6.5).

\subsection{Ensayos de producción de hidrógeno en el fotobiorreactor de $18 \mathrm{~L}$.}

En trabajos reportados en literatura los cultivos de BPNS se mantienen suspendidos por inyección de argón o por recirculación continua del medio. La recirculación continua del medio puede implicar un gasto energético grande por el hecho de mantener funcionando de manera ininterrumpida la bomba empleada para movilizar el líquido y provocar la agitación (Carlozzi \& Sacchi, 2001; Gebicki et al., 2010; Hoekema et al., 2002). En este trabajo, con la finalidad de evitar los dos inconvenientes anteriores la agitación del medio líquido se hizo por recirculación de manera intermitente. Para ello se hicieron ensayos de producción de hidrógeno con diferentes frecuencias de agitación para optimizar la suspensión de la biomasa y mejorar la producción de hidrógeno.

\subsubsection{Diseño experimental}

Para la realización de esta actividad se operó en lote y se probaron 5 frecuencias de encendido de la bomba de recirculación, cada 12, 4, 2, 1.5 y $1 \mathrm{~h}$ a un flujo de $750 \mathrm{~mL} \mathrm{~min}^{-1}$ por 6 minutos. Una vez que la biomasa creció se inició la agitación intermitente en intervalos de 6 minutos con la frecuencia correspondiente. En el reactor plano de $18 \mathrm{~L}$ se trabajó con un volumen de líquido de $15 \mathrm{~L}$, se utilizaron DFE-UAM con una dilución de 1 a 7 y el pH inicial se ajustó a 6.0. El inóculo fue el cultivo IZT. Al arranque del reactor se purgó con Ar hasta asegurar condiciones anaerobias, ya en condiciones anaerobias se hizo vacío para reducir la presión aproximadamente en $5 \mathrm{~cm} \mathrm{Hg}$. Del espacio gaseoso 
se extrajo el biogás producido cada vez que la presión dentro del reactor llegaba a la presión atmosférica para mantener la presión referida.

Las cinco frecuencias de agitación probadas en este capítulo se llevaron a cabo con DFE-UAM de diferentes lotes de fermentación oscura lo que provocó que la concentración de biomasa entre cada exprimento variara y para hacer una comparación justa entre cada experimento la producción de hidrógeno se reporta en base al volumen de $\mathrm{H}_{2}$ producido por unidad de biomasa (expresada como peso seco) $\mathrm{mL} \mathrm{H}_{2} \mathrm{~g}^{-1}$ peso seco, además de dar la Pacum $\mathrm{H}_{2}$ en $\mathrm{mL} \mathrm{L}^{-1}$ de DFE diluido.

\subsubsection{Resultados}

En los experimentos en botellas serológicas, mostrados en los capítulos anteriores, el medio sólo se agitó de manera manual dos veces al día, partiendo de esto, como control el primer ensayo en el fotobiorreactor sólo se agitó 2 veces al día (cada 12 horas). En la Figura 6.7 se presenta la cinética de producción acumulada de hidrógeno por este sistema. Para el día 4 la biomasa alcanzó la fase estacionaria y comenzó la producción de hidrógeno, la concentración de biomasa se mantuvo en en promedio alrededor de $0.525 \pm 0.012 \mathrm{~g}_{\text {peso seco }} \mathrm{L}^{-1}$.

A diferencia de los sistemas en botellas serológicas de $120 \mathrm{~mL}$, en los que la producción de hidrógeno se sostuvo por más de 20 días, en este caso la producción de hidrógeno soló dura alrededor de 8 días

y la producción acumulada de hidrógeno (Pacum $\mathrm{H}_{2}$ ) fue baja (306 mL H $\mathrm{LL}^{-1}$ ó $610 \mathrm{~mL} \mathrm{H}_{2} \mathrm{~g}^{-1}$ peso seco) en comparación con lo que se obtuvo en botellas serológicas en el mismo lapso de tiempo (2300 mL $\mathrm{H}_{2} \mathrm{~g}^{-1}$ peso seco 0 $1150 \mathrm{~mL} \mathrm{H} \mathrm{L}^{-1}$ ). La remoción de DQO fue sólo del $30 \%$ y la de AGVs del $50 \%$. 


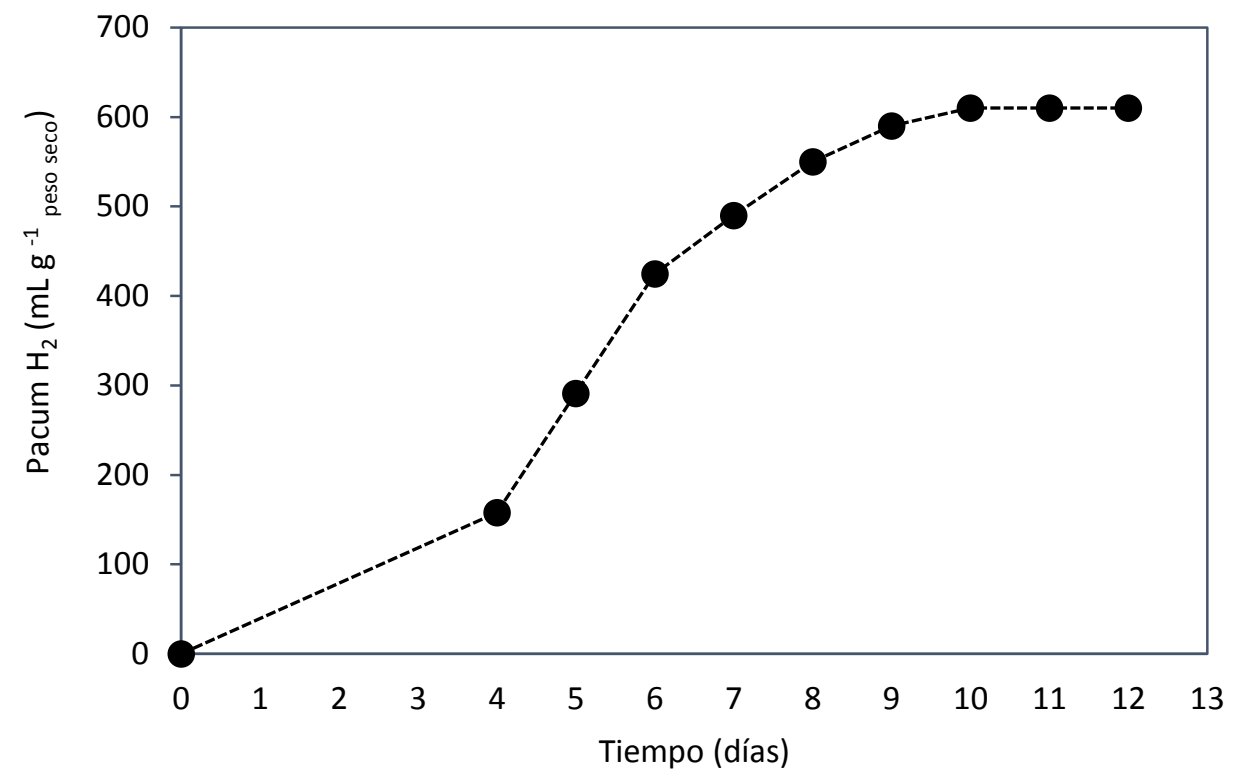

Figura 6.7. Cinética de producción acumulada de $\mathrm{H}_{2}$ por el experimento con agitación cada 12 horas

La causa de los bajos rendimientos fue la sedimentación de la biomasa en el fondo del reactor, pues esto evitó una buena exposición del cultivo a la luz y la agitación cada 12 horas resultó insuficiente. Aunque en las botellas serológicas la biomasa también sedimentó en el fondo, la distancia entre la superficie iluminada y el fondo de la botella solo fue de $2.7 \mathrm{~cm}$. En el fotobiorreactor se respetó el grosor de $2.7 \mathrm{~cm}$, sin embargo la disposición de éste en forma vertical provocó que la mayoría de la biomasa permaneciera en el fondo y por lo tanto hubo poca exposición del cultivo a la luz. Una disposición del fotobiorreactor en forma horizontal no fue considerada debido a que el espacio requerido para su instalación sería mayor y sería más difícil resuspender la biomasa.

En el segundo ensayo se aumentó la frecuencia de agitación a 6 veces al día (cada 4 horas por 6 minutos), bajo estas condiciones la producción de hidrógeno comenzó al día 3 (ver Figura 6.8) y se mantuvo alrededor de 19 días alcanzando una Pacum $\mathrm{H}_{2}$ de $1620 \mathrm{~mL} \mathrm{H}_{2} \mathrm{~g}^{-1}$ peso seco (equivalente a 830 $\mathrm{mL} \mathrm{H}_{2} \mathrm{~L}^{-1}$ ), se removió el $45 \%$ de la DQO y $60 \%$ de los AGVs al final del proceso. 


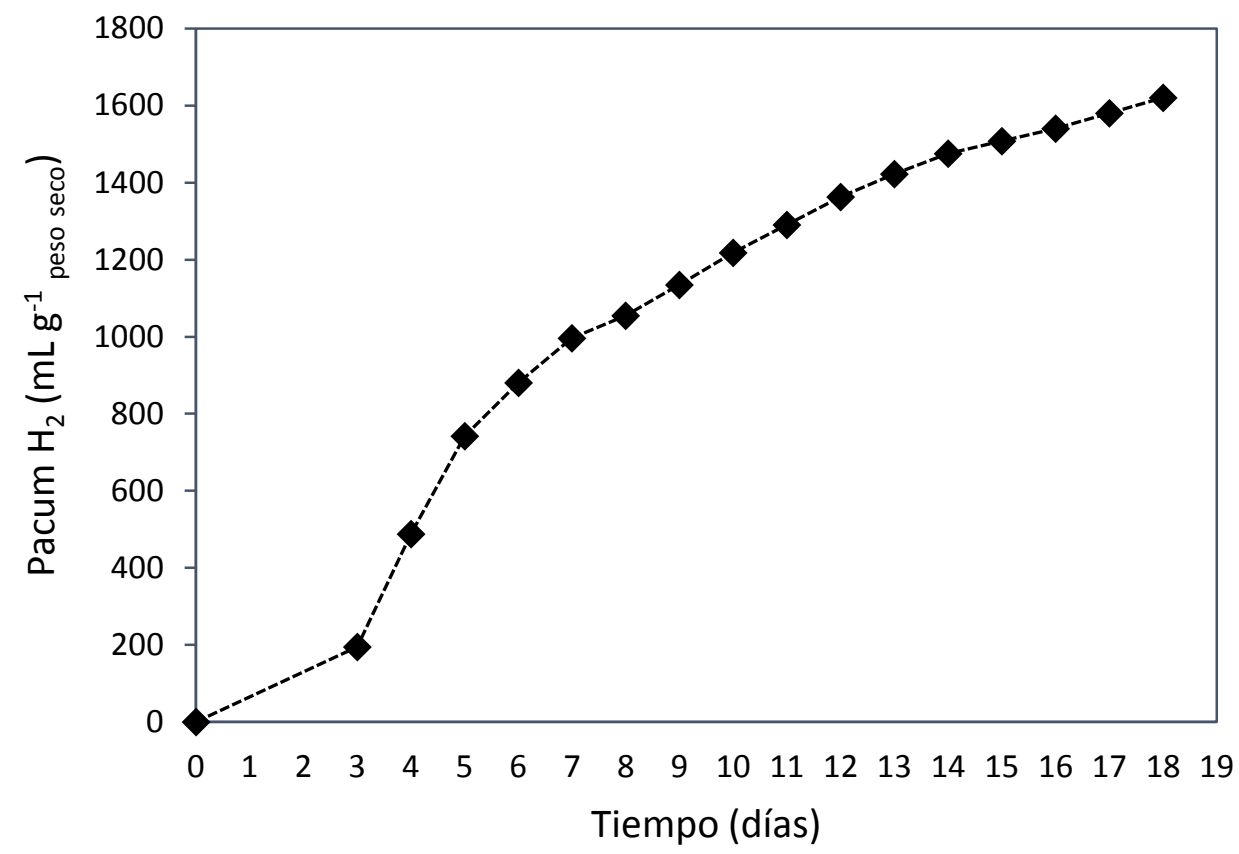

Figura 6.8. Cinética de producción acumulada de $\mathrm{H}_{2}$ por el experimento con agitación cada 4 horas

En la figura 6.9 se muestra la cinética de Pacum $\mathrm{H}_{2}$ para para el experimento que fue agitado 12 veces al día, cada 2 horas por seis minutos, en este esquema de agitación el inicio de la producción de hidrógeno fue más rápido (día 2) y el proceso se mantuvo 22 días alcanzando una Pacum $\mathrm{H}_{2}$ de 2470 $\mathrm{mL} \mathrm{H}_{2} \mathrm{~g}^{-1}$ peso seco (equivalente a $1570 \mathrm{~mL} \mathrm{H}_{2} \mathrm{~L}^{-1}$ ) (ver figura 6.9), la remoción de DQO fue del $62 \%$ y la de AGVs $75 \%$ las cuales son más altas que el experimento agitado cada 4 horas. 


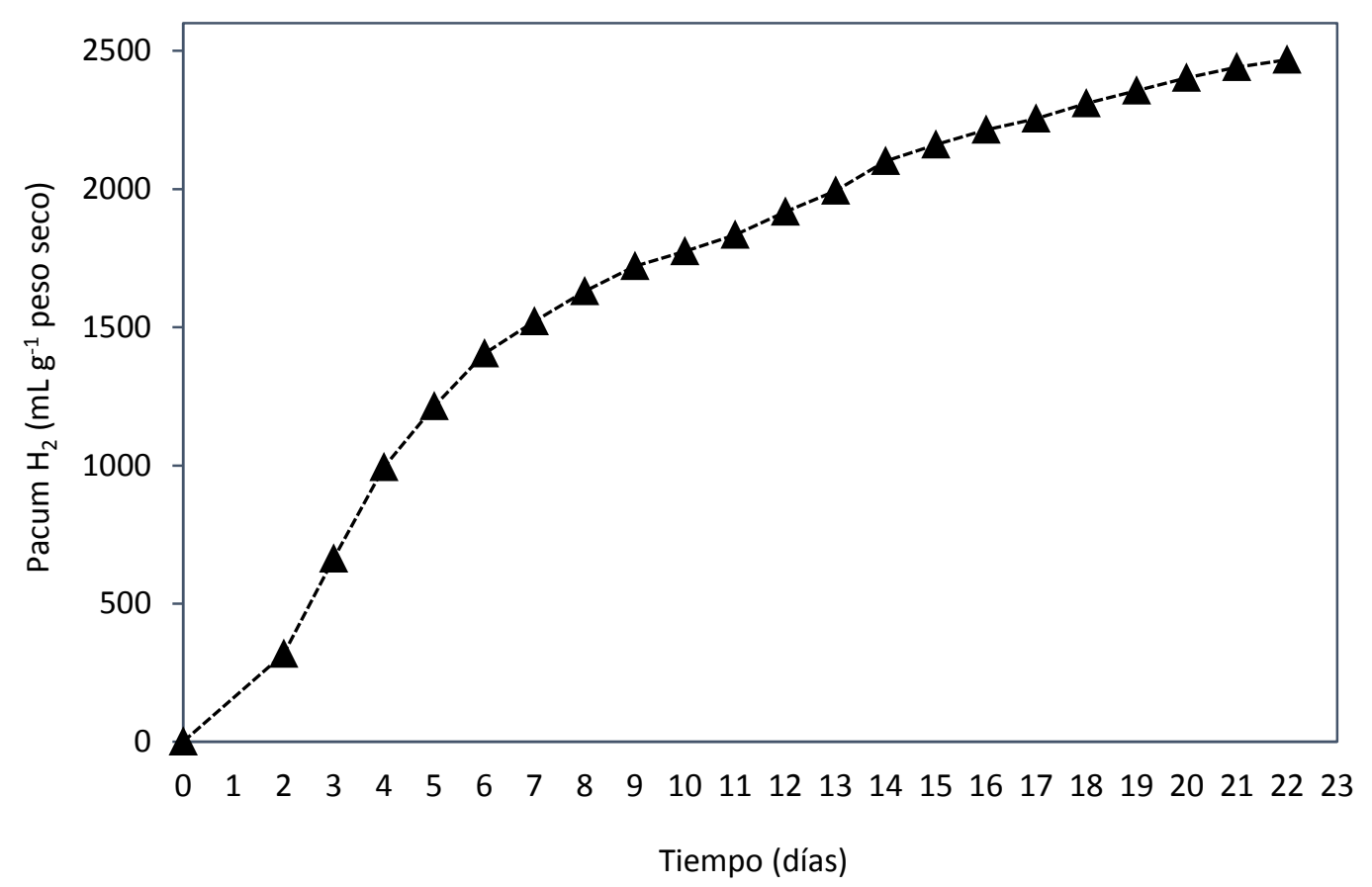

Figura 6.9. Cinética de producción acumulada de hidrógeno por el experimento con agitación cada 2 horas

El siguiente ensayo de producción de hidrógeno en el fotobiorreactor fue para probar una frecuencia de agitado de 18 veces al día, cada 1.5 horas por seis minutos. En este experimento, la producción de hidrógeno inicia al día 2 y con una tasa un poco más alta que en el experimento de agitación cada 2 horas, al final alcanzó una Pacum $\mathrm{H}_{2}$ de $2270 \mathrm{~mL} \mathrm{H}_{2} \mathrm{~g}^{-1}$ peso seco (equivalente a $1153 \mathrm{~mL} \mathrm{H}_{2} \mathrm{~L}^{-1}$ ) (ver figura 6.10), una remoción de DQO del $57 \%$ y de AGVs del $81 \%$. El proceso sólo se mantuvo por 12 días debido a que al final de este lapso de tiempo la biomasa del reactor paso de ser color rojo a café oscuro y la producción de hidrógeno se detuvo. Una de las posibles causas pudo ser la entrada de oxígeno al sistema, que con el aumento de la frecuencia de agitación expuso el cultivo al oxígeno, el cual es nocivo para el fotosistema y la nitrogenasa de las BPNS (ver capítulo 1). Una segunda causa pudo ser que al aumentar la frecuencia de utilización de la bomba peristáltica se haya causado daño 
celular. Se ha postulado que un mezclado con alta turbulencia incrementa la utilización de la luz por los microorganismos (Troesch et al., 2003), sin embargo también se ha reportado daño celular por el alto esfuerzo cortante que causa un mezclado altamente turbulento (Hoekema et al., 2002). En literatura se ha reportado que al aumentar la velocidad de agitación después del punto óptimo la producción de hidrógeno se ve afectada, Li et al. (2011) encontraron que una velocidad de agitación de 120 rpm fue la óptima y cuando aumentaron la velocidad a 160 rpm la producción de hidrógeno y el tiempo de fermentación del proceso disminuyeron. Gebicki et al. (2010) para encontrar el flujo óptimo de recirculación para agitar el medio de cultivo de un reactor tubular de $65 \mathrm{~L}$ fueron variando de 6000 a 10 el número de Reynolds cambiando la velocidad de bombeo. En el rango turbulento 6000 y 2400 no hubo producción de hidrógeno. La producción máxima de hidrógeno se presentó en el rango laminar a una velocidad de bombeo de $20 \mathrm{~L} \mathrm{~h}^{-1}$.

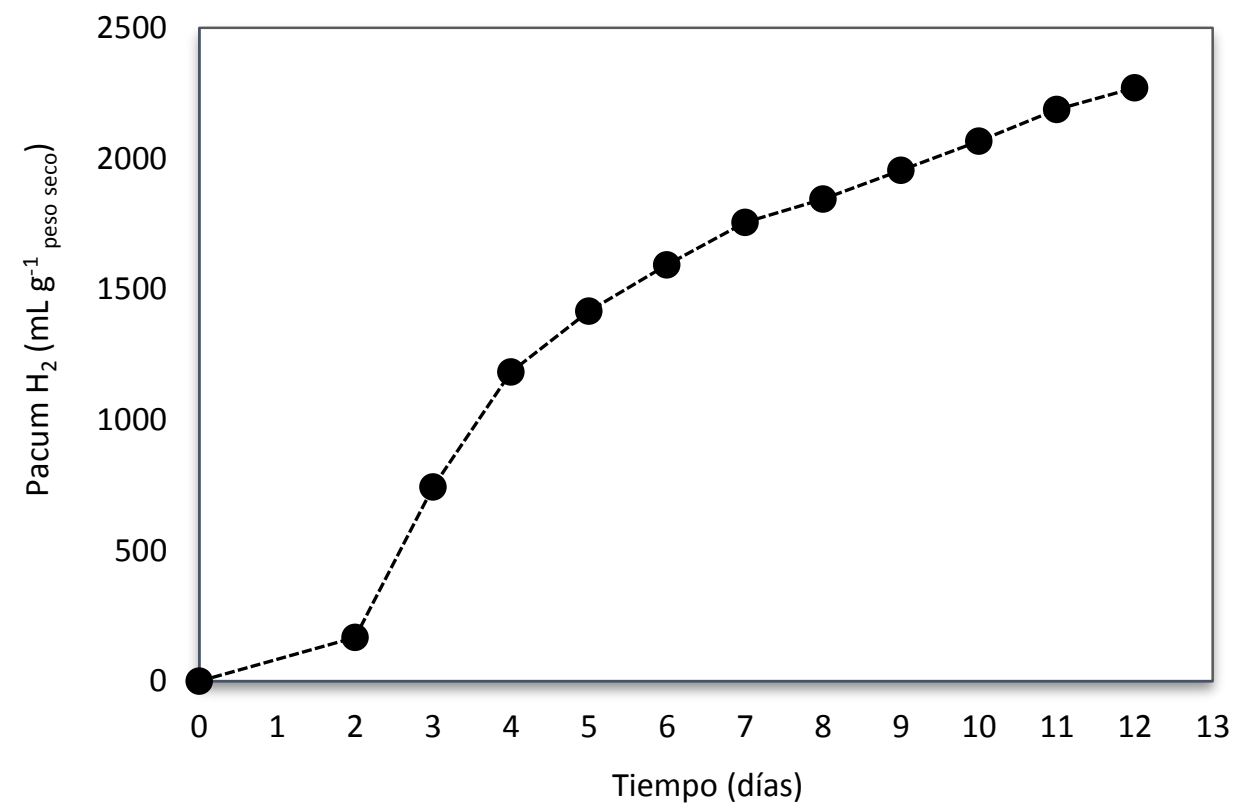

Figura 6.10. Cinética de producción acumulada de $\mathrm{H}_{2}$ por el experimento con agitación cada 1.5 horas 
Estos factores se trataron de comprobar haciendo otro ensayo donde se utilizó una frecuencia de agitación de 24 veces al día, cuidando la hermeticidad del fotobiorreactor para evitar la posible entrada de oxígeno al sistema. En este caso, la producción de hidrógeno fue muy baja, la biomasa creció de forma correcta al inicio y alcanzó la concentración de los experimentos anteriores (aproximadamente $0.5 \mathrm{~g}$ peso seco $\left.\mathrm{L}^{-1}\right)$. La producción de hidrógeno inició al tercer día, pero una vez que se inició la agitación, la biomasa se tornó de color café-rojizo y se detuvo la producción de $\mathrm{H}_{2}$.

Para este experimento se midió la concentración de oxígeno en el espacio gaseoso del reactor, la cual resultó ser de 1\%. Aunque esta concentración es baja y similar a lo que se tiene inicialmente en los experimentos realizados en botellas serológicas de $120 \mathrm{~mL}$ con vacío sin agitación la producción de $\mathrm{H}_{2}$ se detuvo.

En la tabla 6.1 se muestran los resultados de Pacum $\mathrm{H}_{2}$, concentración de biomasa, remoción de DQO y AGVs para los 5 tratamientos con diferente frecuencia de agitación. Debido a que en los experimentos agitados cada 12 horas y cada 1.5 horas la producción de hidrógeno se mantuvo solo por 12 días, se hizo la comparación de todos los tratamientos hasta el día 12. En esta tabla se puede ver que los tratamiento con agitacón cada $2 \mathrm{~h}$ y $1.5 \mathrm{~h}$ tuvieron prácticamente la misma Pacum $\mathrm{H}_{2}$ expresada como $m L H_{2} L^{-1}$, sin embargo la concentración de biomasa en ambos tratamientos fue diferente, como se mencionó en el apartado 6.3.1 cada experimento se llevó a cabo con DFE-UAM de diferentes lotes de fermentación oscura y aunque esta siempre se realizó bajo las mismas condiciones

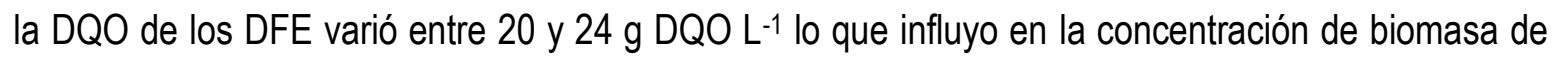
cada exprimento; para hacer una comparación justa entre cada experimento la producción de hidrógeno se calculó en base al volumen de $\mathrm{H}_{2}$ producido por unidad de biomasa. Así que al comparar la producción de $\mathrm{H}_{2}$ en base a la concentración de biomasa el tratamiento agitado cada $1.5 \mathrm{~h}$ presentó la producción más alta, $2270 \mathrm{~mL} \mathrm{H} \mathrm{g}^{-1}$ peso seco. 
Con respecto a datos reportados en literatura, Gilbert et al. (2011) obtuvo una producción acumulada de hidrógeno de $592 \mathrm{~mL} \mathrm{~L}^{-1}$ de medio (empleando un reactor plano de aproximadamente $2 \mathrm{~L}$ agitado por balanceo) la cual es mucho más baja que los $1160 \mathrm{~mL} \mathrm{H}_{2} \mathrm{~L}^{-1}$ y $1153 \mathrm{~mL} \mathrm{H}_{2} \mathrm{~L}^{-1}$ que se obtuvieron en este trabajo para los tratamientos con agitación cada 2 horas y $1.5 \mathrm{~h}$, respectivamente. Adessi et al. (2012) reporta una producción de $1200 \mathrm{~mL} \mathrm{H}_{2} \mathrm{~L}^{-1}$ cultivo empleando un reactor tubular de $50 \mathrm{~L}$ agitado constantemente. Gebicki et al. (2010) reporta una producción de $680 \mathrm{~mL} \mathrm{H}_{2} \mathrm{~L}^{-1}$ cultivo para un fotobiorreactor tubular de $65 \mathrm{~L}$, mientras que para un reactor de plano de 4 placas de $25 \mathrm{~L}, 960 \mathrm{~mL} \mathrm{H}_{2}$ $\mathrm{L}^{-1}$ cultivo. Boran et al. (2010) obtuvo $1000 \mathrm{~mL} \mathrm{H}_{2} \mathrm{~L}^{-1}$ cultivo en un reactor tubular de $80 \mathrm{~L}$.

Tabla 6.1. Resultados de Pacum $\mathrm{H}_{2}$, remoción de DQO y AGVs para el día 12 de operación

\begin{tabular}{|c|c|c|c|c|c|}
\hline Tratamiento & $\begin{array}{c}\text { Agitación cada } \\
12 \mathrm{~h} .\end{array}$ & $\begin{array}{c}\text { Agitación cada } \\
4 \mathrm{~h} .\end{array}$ & $\begin{array}{c}\text { Agitación cada } \\
2 \mathrm{~h} .\end{array}$ & $\begin{array}{c}\text { Agitación cada } \\
1.5 \mathrm{~h} .\end{array}$ & $\begin{array}{c}\text { Agitación cada } \\
1 \mathrm{~h} .\end{array}$ \\
\hline $\begin{array}{c}\text { Pacum } \mathrm{H}_{2} \text { especifica } \\
\left(\mathrm{mL} \mathrm{H}_{2} \mathrm{~g}^{-1} \text { peso seco) }\right.\end{array}$ & 610 & 1360 & 1920 & 2270 & 400 \\
\hline $\begin{array}{l}\text { Pacum } \mathrm{H}_{2} \\
\left(\mathrm{~mL} \mathrm{H}_{2} \mathrm{~L}^{-1}\right)\end{array}$ & 306 & 697 & 1160 & 1153 & 400 \\
\hline $\begin{array}{l}\text { Conc. promedio de } \\
\text { biomasa } \\
\left(\mathrm{g}^{-1} \text { peso seco } \mathrm{L}^{-1}\right)\end{array}$ & 0.525 & 0.500 & 0.670 & 0.530 & ---- \\
\hline $\begin{array}{l}\text { Remoción de } \\
\text { DQO (\%) }\end{array}$ & 30 & 36 & 62 & 57 & ---- \\
\hline $\begin{array}{c}\text { Remoción de AGVs } \\
(\%)\end{array}$ & 52 & 46 & 75 & 81 & ---- \\
\hline
\end{tabular}

\subsection{Conclusiones}

Se realizó el diseño, construcción y operación de un fotobiorreactor de acuerdo con los datos hallados en la literatura especializada y considerando los factores de configuración, penetración de la luz, 
relación área volumen, transparencia y durabilidad del material de construcción, control de temperatura y sistema de agitación.

El fotobiorreactor diseñado para la producción de hidrógeno resultó adecuado y económico debido a que el arreglo de lámparas como fuente luminosa que se empleó no sólo suministraron la intensidad luminosa requerida también permitieron mantener la temperatura adecuada del medio sin la necesidad de un sistema de calefacción extra. La agitación intermitente de seis minutos cada 1.5 horas permitió alcanzar los rendimientos de producción de hidrógeno que se obtuvieron en los ensayos previamente realizados en botellas serológicas de $120 \mathrm{~mL}$, aunque el proceso sólo se mantuvo por 12 días. Las causas posibles son la presencia de oxígeno que aunque resultó baja, pudo afectar al cultivo por el aumento en la frecuencia en que se puso en contacto al cultivo con el oxígeno. La otra posibilidad es que el aumento de la frecuencia de agitación dañó las células. Por lo que es necesario profundizar en el efecto de la frecuencia de agitación sobre las células y encontrar el tiempo de agitado óptimo que prolongue la operación sin dañar el cultivo. 


\section{CONCLUSIONES GENERALES}

En este estudio se demostró la factibilidad de producir hidrógeno a partir de efluentes de fermentación oscura en condiciones no estériles por un cultivo enriquecido de bacterias púrpuras no del azufre obtenido de una planta de tratamiento de aguas residuales (denominado IZT). El cultivo fotoheterótrofo

IZT no sólo fue buen productor de hidrógeno como la cepa $R$. capsulatus, sino también fue metabólicamente más robusto, a lo largo de este trabajo no perdió su actividad para producir hidrógeno y siempre tuvo mayor capacidad para remover DQO.

El análisis por técnicas de biología molecular mostró que el cultivo IZT está constituido por un solo microorganismo fotoheterótrofo con $99 \%$ de similitud a la BPNS R. palustris DX1.

La presión reducida o vacío parcial fue la mejor opción para reemplazar el purgado con argón de los fotosistemas no sólo porque cumple con las funciones de propiciar condiciones anaerobias y bajar la presión parcial de $\mathrm{H}_{2}$ en los reactores, también tuvo efecto positivo sobre la Pacum $\mathrm{H}_{2}$ tanto en el proceso de foto-fermentación como en la fermentación oscura. El uso de presión reducida puede ayudar a simplificar el proceso de purificación del hidrógeno al no requerir la separación del $\mathrm{H}_{2}$ del gas usado para purgar y por lo tanto bajar los costos de operación que esto implica.

La adición de bicarbonato a los efluentes de fermentación oscura ricos en ácido butírico es necesaria para mejorar los rendimientos de producción de $\mathrm{H}_{2}$ debido a su desempeño como aceptor del exceso de electrones. 
Aunque la producción de hidrógeno obtenida bajo condiciones ambientales fue menor que la obtenida en condiciones de laboratorio, es técnicamente atractiva considerando el ahorro de energía que implica usar la luz solar como fuente de energía luminosa.

Otra opción para ahorrar energía en el proceso es la utilización de ciclos luz oscuridad artificiales más cortos que los naturales a fin de evitar cambio de metabolismo en las BPNS por pasar periodos de oscuridad largos. En este trabajo la utilización de ciclos luz-oscuridad de 30 minutos permitió con el cultivo IZT obtener la misma producción de hidrógeno que con iluminación continua tanto en los procesos en lote como en lote secuencial. Cabe señalar que este es uno de los primeros trabajos que reporta la producción de hidrógeno en lote secuencial operado bajo iluminación con ciclos luzoscuridad; en estas condiciones fue posible mantener la producción de hidrógeno por más de 30 días. La producción de PHB estubo relacionada con el patrón de iluminación, bajo ciclos luz-oscuridad los cultivos produjeron más PHB y este hecho debe ser explotado para incrementar su acumulación en aquellos cultivos con capacidad para producirlo como fue observado en $R$. capsulatus.

En cuanto al proceso de fermentación oscura para la obtención del DFE-UAM, se encontraron condiciones prácticas y económicas para la producción de $\mathrm{H}_{2}$ a partir de residuos vegetales, como lo es uso de un residuo, cascarón de huevo, para regular el pH en sustitución de reactivos químicos y la desgasificación por vacío. Además se demostró que no es necesaria la suplementación de los residuos vegetales con nutrientes químicos para obtener buenos rendimientos de producción de hidrógeno. La utilización de cascarón de huevo como amortiguador de pH benefició tanto la fermentación oscura como la fotofermentación; en los ensayos de fotofermentación utilizando los DFE-UAM, se observó que estos tienen suficiente alcalinidad, proveniente del cascarón de huevo utilizado en la fermentación oscura, lo cual permitió utilizarlos sin la adición de buffer y bicarbonato, con el consecuente ahorro en el proceso. 
En los ensayos de producción de $\mathrm{H}_{2}$ que se realizaron en el fotobiorreactor de 18 litros se logró alcanzar los rendimientos de producción de hidrógeno (1153 mL L-1) que se obtuvieron en los ensayos previamente realizados en botellas serológicas de $120 \mathrm{~mL}$ en lote mediante la agitación intermitente del medio por recirculación a un flujo de $750 \mathrm{~mL} \mathrm{~min}{ }^{-1}$ por seis minutos cada 1.5 horas.

Finalmente resta decir que las condiciones de operación alternativas a los procesos que emplean cepas puras, argón, incubación controlada, iluminación continua y agitación constante para la producción de $\mathrm{H}_{2}$ contribuyeron a mejorar la producción y podrían contribuir a bajar los costos de operación. 


\section{Perspectivas del trabajo}

Los resultados obtenidos en esta tesis abren la posibilidad de plantear nuevos estudios para una mayor comprensión y mejora del proceso de foto-fermentación por las bacterias púrpuras no del azufre bajo ciclos luz-oscuridad. Valdría la pena llevar a cabo experimentos con el cultivo IZT donde se empleara iluminación intermitente con ciclos de oscuridad más largos que los de luz para determinar el mínimo de luz requerida para mantener una producción de hidrógeno similar a la obtenida bajo iluminación continua, además de monitorear la actividad de la nitrogensa y determinar el comportamiento y estabilidad de esta ante tales condiciones.

Otro aspecto interesante es que la producción de PHB por estos microorganismos esta influenciada por el patrón de iluminación, sería interesante determinar en que periodo, luz u oscuridad, se acumula más PHB para establecer ciclos luz-oscuridad que propicien una mayor acumulación de este polímero en aquellos cultivos que tienen capacidad para producirlo.

Entre las perspectivas debe considerarse además de la obtención de cultivos de BPNS de cuerpos de aguas residuales, el cultivo y aclimatación de estos cultivos a condiciones ambientales para que puedan tener un mejor desempeño en tales condiciones. 


\section{REFERENCIAS}

Abo-Hashesh M., Desaunay N. \& Hallenbeck P. C. (2013). High yield single stage conversion of glucose to hydrogen by photofermentation with continuous cultures of Rhodobacter capsulatus JP91. Bioresource Technol, 128: 513-517.

Adessi A. \& De Philippis R. (2014). Photobioreactor design and illumination systems for $\mathrm{H}_{2}$ production with anoxygenic photosynthetic bacteria: A review. Int J Hydrogen Energy, 39(7): 3127-3141.

Afsar N., Özgür E., Gürgan M., Akköse S., Yücel M., Gündüz U., Eroglu I. (2011). Hydrogen productivity of photosynthetic bacteria on dark fermenter effluent of potato steam peels hydrolysate. Int $\mathrm{J}$ Hydrogen Energy, 36:432-8.

Akkerman I., Janssen M., Rocha J. \& Wijfels R. H. (2002). Photobiological hydrogen production: photochemical efficiency and bioreactor design. Int J Hydrogen Energy, 27(11-12):1195-1208.

Androga D.D., Sevinc P., Koku H., Yücel M., Gündüz U., Eroglu I. (2014). Optimization of temperature and light intensity for improved photofermentative hydrogen production using Rhodobacter capsulatus DSM 1710. Int J Hydrogen Energy. 39:2472-80.

Aparecida Loss R., Fontes M.L., Reginatto V., Vasconcellos Antonio R. (2013).Biohydrogen production by a mixed photoheterotrophic culture obtained from a Winogradsky column prepared from the sediment of southern Brazilian lagoon. Renew Energ, 50:648-54.

Argun H., Kargi F. (2010). Effects of light source, intensity and lighting regime on bio-hydrogen production from ground wheat starch by combined dark and photo-fermentation. Int J Hydrogen Energy,35:1604-1612.

Arreola-Vargas J., Celis L.B., Buitrón G., Razo-Flores E., Alatriste-Mondragón F. Hydrogen production from acid and enzymatic oat straw hydrolysates in an anaerobic sequencing batch reactor: Performance and microbial population analysis. Int J Hydrogen Energy,38:13884-13894.

Avcioglu S.G., Özgür E., Eroglu I., Yücel M., Gündüz U. (2011). Biohydrogen production in an outdoor panel photobioreactor on dark fermentation effluent of molasses. Int J Hydrogen Energy, 36:11360-68.

Azbar N., Dokgöz F.T.C. (2010).The effect of dilution and L-malic acid addition on bio-hydrogen production with Rhodopseudomonas palustris from effluent of an acidogenic anaerobic reactor. Int J Hydrogen Energy,35:5028-33.

Balat M. \& Balat M. (2009). Political, economic and environmental impacts of biomass-based hydrogen. Int J Hydrogen Energy, 34(9):3589-3603.

Basak N., Jana A. K., Das D. \& Saikia D. (2014). Photofermentative molecular biohydrogen production by purple-non-sulfur (PNS) bacteria in various modes: The present progress and future perspective. Int J Hydrogen Energy, 39(13):6853-6871.

Beckers L., Hiligsman, S., Masset, J., \& Thonart, C. H. (2012). Effects of hydrogen partial pressure on fermentative biohydrogen production by a chemotropic Clostridium bacterium in a new horizontal rotating cylinder reactor. Energy Procedia, 29: 34-41.

Bertini I., Sigel H. \& Sigel A. (2001). Handbook on Metalloproteins (pp. 1189). New York. Basel: Marcel Dekker, Inc.

Bleischwitz R., Bader N. \& Trümper S. C. (2010). The socio-economic transition towards a hydrogen economy. Energy Policy, 38(10): 5297-5300.

Boran E., Özgür E., van der Burg J., Yücel M., Gündüz U., Eroglu I. (2010). Biological hydrogen production by Rhodobacter capsulatus in solar tubular photobioreactor. J Clean Prod.18:S29S35. 
Boran E, Özgür E, Yücel M, Gündüz U, Eroglu I. (2012). Biohydrogen production by Rhodobacter capsulatus in solar tubular photobioreactor on thick juice dark fermenter effluent. J Clean Prod. 31:150-157.

Bouallagui H., Touhami Y., Ben Cheikh R. \& Hamdi M. (2005). Bioreactor performance in anaerobic digestion of fruit and vegetable wastes. Process Biochemistry, 40(3-4): 989-995.

Buitrón G., Carvajal C. (2010). Biohydrogen production from Tequila vinasses in an anaerobic sequencing batch reactor: Effect of initial substrate concentration, temperature and hydraulic retention time. Bioresource Technol, 101: 9071-9077. Cai J., Wang G., Pan G. (2012). Hydrogen production from butyrate by a marine mixed phototrophic bacterial consort. Int J Hydrogen Energy, 37:4057-67.

Carlozzi, P. \& Sacchi, A. (2001). Biomass production and studies on Rhodopseudomonas palustris grown in an outdoor, temperature controlled, underwater tubular photobioreactor. J Biotechnol, 88(3): 239-249.

Chan Y. J., Chong M. F., Law C.L. \& Hassell D.G. (2009). A review on anaerobic-aerobic treatment of industrial and municipal wastewater. Chem Eng J, 155(1-2): 1-18.

Chang P.L. \& Hsu C.W. (2012). Value analysis for commercialization of fermentative hydrogen production from biomass. Int J Hydrogen Energy, 37(20), 15746-15752.

Chen X., Sun Y., Xiu Z., Li X. \& Zhang D. (2006). Stoichiometric analysis of biological hydrogen production by fermentative bacteria. International Journal of Hydrogen Energy, 31(4), 539-549.

Chen C.Y., Liu C.H., Lo Y.C., \& Chang J.S. (2011). Perspectives on cultivation strategies and photobioreactor designs for photo-fermentative hydrogen production. Bioresource Technol, 102(18), 8484-8492.

Chen C.Y., Saratale G.D., Lee C.M., Chen P.C., Chang J.S. (2008). Producción de hidrógeno en un fotobiorreactor acoplado con fibras ópticas excitadas por energía solar. Int J Hydrogen Energy, 33: 6886-6895.

Choi J. \& Ahn Y. (2014). Characteristics of biohydrogen fermentation from various substrates. Int J Hydrogen Energy, 39(7): 3152-3159.

Claassen P.A.M., de Vrije T., Koukios E., van Niel E., Eroglu I., Modigell M., ... Ahrer W. (2010). Nonthermal production of pure hydrogen from biomass: HYVOLUTION. J Clean Prod, 18, Supplement 1, S4-S8.

Clark I.C., Zhang R.H. \& Upadhyaya S.K. (2012). The effect of low pressure and mixing on biological hydrogen production via anaerobic fermentation. Int J Hydrogen Energy, 37(15): 11504-11513.

Dasgupta C. N., Jose Gilbert J., Lindblad P., Heidorn T., Borgvang S. A., Skjanes K. \& Das D. (2010). Recent trends on the development of photobiological processes and photobioreactors for the improvement of hydrogen production. Int J Hydrogen Energy, 35(19):10218-10238.

De Gioannis G., Muntoni A., Polettini A. \& Pomi R. (2013). A review of dark fermentative hydrogen production from biodegradable municipal waste fractions. Waste Manage, 33(6): 1345-1361.

Eroglu E., Gündüz U., Yücel M., Eroglu I. (2011). Effect of iron and molybdenum addition on photofermentative hydrogen production from olive mill wastewater. Int J Hydrogen Energy, 36:5895-5903.

Eroglu E., Gündüz U., Yücel M., Türker L., Eroglu I. (2004). Photobiological hydrogen production by using olive mil wastewater as a sole substrate source. Int J Hydrogen Energy, 29:1527-35.

Eroglu E., Eroglu I., Gündüz U., Türker L., Yücel M. (2006). Biological hydrogen production from olive mill wastewater with two-stage processes. Int J Hydrogen Energy, 31:1527-35.

Eroglu E. \& Melis A. (2011). Photobiological hydrogen production: Recent advances and state of the art. Bioresource Technol, 102(18): 8403-8413. 
Eroğlu I., Tabanoğlu A., Gündüz U., Eroğlu E. \& Yücel M. (2008). Hydrogen production by Rhodobacter sphaeroides 0.U.001 in a flat plate solar bioreactor. Int J Hydrogen Energy, 33(2):531-541.

Faloye F.D., Gueguim Kana E.B. \& Schmidt S. (2014). Optimization of biohydrogen inoculum development via a hybrid $\mathrm{pH}$ and microwave treatment technique - Semi pilot scale production assessment. Int J Hydrogen Energy, 39(11):5607-5616.

Fradinho J.C., Oehmen A. \& Reis M.A.M. (2013). Effect of dark/light periods on the polyhydroxyalkanoate production of a photosynthetic mixed culture. Bioresource Technol, 148: 474-479.

Gabrielyan L., Sargsyan H., Hakobyan L., \& Trchounian A. (2014). Regulation of hydrogen photoproduction in Rhodobacter sphaeroides batch culture by external oxidizers and reducers. Appl Energ, 131: 20-25.

Gebicki, J., Modigell, M., Schumacher, M., van der Burg, J., \& Roebroeck, E. (2010). Comparison of two reactor concepts for anoxygenic $\mathrm{H} 2$ production by Rhodobacter capsulatus. J Clean Prod, 18, Supplement 1, S36-S42.

Gest H., Ormerod J. G. \& Ormerod K.S. (1962). Photometabolism of Rhodospirillum rubrum: Lightdependent dissimilation of organic compounds to carbon dioxide and molecular hydrogen by an anaerobic citric acid cycle. Arch Biochem and Biophys, 97(1): 21-33.

Ghimire A., Frunzo L., Pirozzi F., Trably E., Escudie R., Lens P. N. L. \& Esposito G. (2015). A review on dark fermentative biohydrogen production from organic biomass: Process parameters and use of by-products. Appl Energ, 144: 73-95.

Gilbert J. J., Ray S. \& Das D. (2011). Hydrogen production using Rhodobacter sphaeroides (O.U. 001) in a flat panel rocking photobioreactor. Int J Hydrogen Energy, 36(5): 3434-3441.

Golomysova A., Gomelsky M. \& Ivanov P.S. (2010). Flux balance analysis of photoheterotrophic growth of purple nonsulfur bacteria relevant to biohydrogen production. Int J Hydrogen Energy, 35(23): $12751-12760$.

Gómez X., Cuetos M. J., Prieto J. I. \& Morán A. (2009). Bio-hydrogen production from waste fermentation: Mixing and static conditions. Renew Energ, 34(4): 970-975.

Guevara J. A. G. \& Montiel V.C. (2014). Pushing Mexico to a Recycle Culture. In J. Galindo (Ed.), México in Focus: Political, Environmental and Social Issues (pp. 141-176). Hauppauge, NY, USA: Nova Science.

Guwy A.J., Dinsdale R.M., Kim J.R., Massanet-Nicolau J. \& Premier G. (2011). Fermentative biohydrogen production systems integration. Bioresource Technol, 102(18), 8534-8542.

Hallenbeck P. C. \& Benemann J. R. (2002). Biological hydrogen production; fundamentals and limiting processes. Int J Hydrogen Energy, 27(11-12): 1185-1193.

Hay J.X.W., Wu T.Y. \& Juan J.C. (2013). Biohydrogen production through photo fermentation or dark fermentation using waste as a substrate: Overview, economics, and future prospects of hydrogen usage Biofuels. Bioprod. Bioref, 7: 334-352.

Hiligsmann S., Masset J., Hamilton C., Beckers L. \& Thonart P. (2011). Comparative study of biological hydrogen production by pure strains and consortia of facultative and strict anaerobic bacteria. Bioresource Technol, 102(4):3810-3818.

Hillmer P. \& Gest H. (1977). $\mathrm{H}_{2}$ metabolism in the photosynthetic bacterium Rhodopseudomonas capsulata: $\mathrm{H}_{2}$ production by growing cultures. J Bacteriol, 129(2), 724-731.

Hoekema S., Bijmans M., Janssen M., Tramper J. \& Wijfels R. H. (2002). A pneumatically agitated flat-panel photobioreactor with gas re-circulation: anaerobic photoheterotrophic cultivation of a purple non-sulfur bacterium. Int J Hydrogen Energy, 27(11-12): 1331-1338. 
Hustede E., Steinbüchel A. \& Schlegel H. (1993). Relationship between the photoproduction of hydrogen and the accumulation of PHB in non-sulphur purple bacteria. Appl Microbiol Biot, 39(1): 87-93.

IEA. (2012). $\mathrm{CO}_{2}$ Emissions Overview. Retrieved from http://www.iea.org/media/statistics/ topics/emissions/CO2_Emissions_Overview.pdf

lenczak J.L, Schmidell W, Aragao G.M.F. (2013). High-cell-density culture strategies for polyhydroxyalkanoate production: a review. J Ind Microbiol Biotechnol, 40:275-86.

Jouanneau Y., Wong B., \& Vignais P. M. (1985). Stimulation by light of nitrogenase synthesis in cells of Rhodopseudomonas capsulata growing in N-limited continuous cultures. Biochimica et Biophysica Acta (BBA) - Bioenergetics, 808(1): 149-155.

Kapdan I. K. \& Kargi F. (2006). Bio-hydrogen production from waste materials. Enzyme Microb Tech, 38(5): 569-582.

Kars G., \& Gündüz U. (2010). Towards a super $\mathrm{H}_{2}$ producer: Improvements in photofermentative biohydrogen production by genetic manipulations. Int J Hydrogen Energy, 35(13): 6646-6656.

Kars G., Gündüz U., Rakhely G., Yücel M., Eroğlu I. \& Kovacs K.L. (2008). Improved hydrogen production by uptake hydrogenase deficient mutant strain of Rhodobacter sphaeroides O.U.001. Int J Hydrogen Energy, 33(12): 3056-3060.

Kataoka N., Miya A., \& Kiriyama K. (1997). Studies on hydrogen production by continuous culture system of hydrogen-producing anaerobic bacteria. Water Sci Technol, 36(6-7): 41-47.

Khatipov E, Miyake M, Miyake J, Asada Y. (1998). Accumulation of poly-beta-hydroxybutyrate by Rhodobacter sphaeroides on various carbon and nitrogen substrates. FEMS Microbiol Lett, 162:39-45.

Kim D.H., Kim M.S. (2013). Development of a novel three-stage fermentation system converting food waste to hydrogen and methane. Bioresource Technol, 127:267-74.

Kim D.H., Shin H.S., Kim S.H. (2012). Enhanced $\mathrm{H}_{2}$ fermentation of organic waste by $\mathrm{CO}_{2}$ sparging. Int J Hydrogen Energy, 37:15563 -68.

Kim E.J., Lee M.K., Kim M.S. \& Lee J.K. (2008). Molecular hydrogen production by nitrogenase of Rhodobacter sphaeroides and by Fe-only hydrogenase of Rhodospirillum rubrum. Int $\mathrm{J}$ Hydrogen Energy, 33(5): 1516-1521.

Kim M.S., Kim D.H., Cha J, Lee J.K. (2012). Effect of carbon and nitrogen sources on photofermentative $\mathrm{H}_{2}$ production associated with nitrogenase, uptake hydrogenase activity, and PHB accumulation in Rhodobacter sphaeroides KD131. Bioresource Technol, 116:179-183.

Kirtay E. (2011). Recent advances in production of hydrogen from biomass. Energ Convers Manage, 52(4): 1778-1789.

Koku H, Eroğlu I, Gündüz U, Yücel M, Türker L. (2002). Aspects of the metabolism of hydrogen production by Rhodobacter sphaeroides. Int. J. Hydrogen Energy, 27:1315-29.

Koku H, Eroglu I, Gündüz U, Yücel M, Türker L. (2003). Kinetics of biological hydrogen production by the photosynthetic bacterium Rhodobacter sphaeroides O.U. 00. Int J Hydrogen Energy, 28:381-88.

Kontur W.S., Noguera D.R., Donohue T.J. (2012). Maximizing reductant flow into microbial $\mathrm{H}_{2}$ production. Curr Opin Biotechnol, 23(3):382-89.

Kothari R., Pandey A.K., Kumar S., Tyagi V. V. \& Tyagi S. K. (2014). Different aspects of dry anaerobic digestion for bio-energy: An overview. Renew Sust Energ Rev, 39: 174-195.

Kothari R., Singh, D. P., Tyagi, V. V., \& Tyagi, S. K. (2012). Fermentative hydrogen production - An alternative clean energy source. Renew Sust Energ Rev, 16(4), 2337-2346.

Kothari R., Tyagi V.V. \& Pathak A. (2010). Waste-to-energy: A way from renewable energy sources to sustainable development. Renew Sust Energ Rev, 14(9), 3164-3170. 
Kranz R.G., Gabbert K.K., Locke T.A., \& Madigan M.T. (1997). Polyhydroxyalkanoate production in Rhodobacter capsulatus: genes, mutants, expression, and physiology. Appl Environ Microb, 63(8): 3003-3009.

Kumar-Khanal, S. (2009). Biohydrogen Production: Fundamentals, Challenges, and Operation Strategies for Enhanced Yield. In S. K. Khanal (Ed.), Anaerobic Biotechnology for Bioenergy Production: Principles and Applications (pp. 189-219): John Wiley \& Sons, Inc.

Laguna R, Joshi G.S., Dangel A.W., Luther A.K., Tabita F.R. (2010). Integrative control of carbon, nitrogen, hydrogen, and sulfur metabolism: the central role of the Calvin-Benson- Bassham cycle. Adv Exp Med Biol., 675:265-71.

Laguna R. (2010). Interactive Control of Carbon Assimilation, Redox Balance, CBB Expression, Nitrogenase Complex Biosynthesis, Hydrogen Production, and Sulfur Metabolism in RubisCO Compromised Mutant Strains of Nonsulfur Purple Bacteria. (PhD), The Ohio State University, Ohio State.

Lazaro C.Z., Vich D.V., Hirasawa J.S., Varesche M.B.A. (2012). Hydrogen production and consumption of organic acids by a phototrophic microbial consortium. Int J Hydrogen Energy, 37:11691700.

Lee Z.K., Li S.L., Lin J.S., Wang Y.H., Kuo P.C. \& Cheng S.S. (2008). Effect of pH in fermentation of vegetable kitchen wastes on hydrogen production under a thermophilic condition. Int $\mathrm{J}$ Hydrogen Energy, 33(19): 5234-5241.

Levin D.B., Pitt L., \& Love M. (2004). Biohydrogen production: prospects and limitations to practical application. Int J Hydrogen Energy, 29(2): 173-185.

Li R.Y, Zhang T., Fang H.H.P. (2008). Characteristics of a phototrophic sludge producing hydrogen from acetate and butyrate. Int J Hydrogen Energy, 33:2147-55.

Li X., Wang Y., Zhang S., Chu J., Zhang M., Huang M., Zhuang Y. (2011). Effects of light/dark cycle, mixing pattern and partial pressure of $\mathrm{H}_{2}$ on biohydrogen production by Rhodobacter sphaeroides ZX-5. Bioresource Technol., 102:1142-48.

Liao Q., Wang Y. J., Wang Y. Z., Zhu X., Tian X., Li J. (2010). Formation and hydrogen production of photosynthetic bacterial biofilm under various illumination conditions. Bioresource Technol 101: 5315-5324.

Lin C.Y., Lay C.H., Sen B., Chu C.Y., Kumar G., Chen C.C., \& Chang J.S. (2012). Fermentative hydrogen production from wastewaters: A review and prognosis. Int $\mathrm{J}$ Hydrogen Energy, 37(20):15632-15642.

Liu B.F., Ren N.Q. Ding J., Xie G.J. \& Cao G.L. (2009). Enhanced photo- $\mathrm{H}_{2}$ production of $R$. faecalis RLD-53 by separation of $\mathrm{CO}_{2}$ from reaction system. Bioresource Technol, 100(3):1501-1504.

Lo Y.C., Chen C.Y., Lee C.M., \& Chang J.S. (2011). Photo fermentative hydrogen production using dominant components (acetate, lactate, and butyrate) in dark fermentation effluents. Int $\mathrm{J}$ Hydrogen Energy, 36(21):14059-14068.

Logan B. E., Oh S.-E., Kim I. S., \& Van Ginkel S. (2002). Biological Hydrogen Production Measured in Batch Anaerobic Respirometers. Environ Sci \& Technol, 36(11), 2530-2535.

Madigan M. T., Martinko J. M., \& Parker J. (2004). Brock. Biología de los Microorganismos (10a ed.). Madrid, España: Pearson Education, S.A.

Mandal B., Nath K., \& Das D. (2006). Improvement of Biohydrogen Production Under Decreased Partial Pressure of $\mathrm{H}_{2}$ by Enterobacter cloacae. Biotechnol Lett, 28(11), 831-835.

Markov S.A., Lichtl R., Rao K.K., Hall D.O. (1993). A Hollow fibre photobioreactor for continuous production of hydrogen by immobilized cyanobacteria under partial vacuum. Int J Hydrogen Energy, 18:901-6. 
McKinlay J. B., Oda Y., Rühl M., Posto A. L., Sauer U., \& Harwood C. S. (2014). Non-growing Rhodopseudomonas palustris Increases the Hydrogen Gas Yield from Acetate by Shifting from the Glyoxylate Shunt to the Tricarboxylic Acid Cycle. J Biol Chem, 289(4):1960-1970.

McKinlay J.B., \& Harwood C.S. (2010). Photobiological production of hydrogen gas as a biofuel. Curr Opin Biotech, 21(3):244-251.

Melis A., \& Melnicki M. R. (2006). Integrated biological hydrogen production. Int J Hydrogen Energy, 31(11):1563-1573.

Meyer J, Kelley BC, Vignais PM. (1978). Effect of light on nitrogenase function and synthesis in Rhodopseudomonas capsulata. J Bacteriol,136(1):201-8.

Miyake, J., Wakayama, T., Schnackenberg, J., Arai, T., \& Asada, Y. (1999). Simulation of the daily sunlight illumination pattern for bacterial photo-hydrogen production. J Biosci Bioeng, 88(6):659-663.

Mohan S.V., Mohanakrishna G., Kannaiah G R., Sarma P.N. (2009). Acidogenic fermentation of vegetable based market waste to harness biohydrogen with simultaneous stabilization. Bioresource Technol, 100(12):3061-8.

Mohan, S. V., Srikanth, S., Dinakar, P., \& Sarma, P. N. (2008). Photo-biological hydrogen production by the adopted mixed culture: Data enveloping analysis. Int J Hydrogen Energy, 33(2):559569 .

Montiel-Corona V, Revah S, Morales M. (2015). Hydrogen production by an enriched photoheterotrophic culture using dark fermentation effluent as substrate: Effect of flushing method, bicarbonate addition, and outdoor e indoor conditions. Int J Hydrogen Energy, 40:90969105.

Montiel-Corona, V., Sánchez-Camarillo, A. R., \& Guevara-García, J. A. (2010). Biohidrógeno a partir de basura orgánica. Ciencia, Tecnología e Innovación para el Desarrollo de México, PCTI, $3(66)$.

Mohr S.H., Wang J., Ellem G., Ward J., Giurco D. (2015). Projection of world fossil fuels by country. Fuel, 141: 120-135

Muller F.M. (1933). On the metabolism of the purple sulphur bacteria in organic media. Arch. Mikrobiol, 4:131-66.

Ntaikou I., Antonopoulou G., \& Lyberatos, G. (2010). Biohydrogen Production from Biomass and Wastes via Dark Fermentation: A Review. Waste Biomass Valorization, 1(1): 21-39.

Oncel S., Vardar-Sukan F. (2009). Photo-bioproduction of hydrogen by Chlamydomonas reinhardtii using a semi-continuous process regime. Int J Hydrogen Energy, 34: 7592-7602.

Oncel S., Kose A. (2014). Comparison of tubular and panel type photobioreactors for biohydrogen production utilizing Chlamydomonas reinhardtii considering mixing time and light intensity. Bioresource Technol, 151:265-270

Ormerod J.G, Gest H. (1962). Hydrogen photosynthesis and alternative metabolic pathways in photosynthetic bacteria. Bacteriol Rev, 26:51-66.

Ormerod, J. G. (1956). The use of radioactive carbon dioxide in the measurement of carbon dioxide fixation in Rhodospirillum rubrum. Biochem J, 64(2): 373-380.

Özgür E, Uyar B, Ozturk Y, Yücel M, Gündüz U, Eroglu I. (2010). Biohydrogen production by Rhodobacter capsulatus on acetate at fluctuating temperatures. Resour, Conserv Recy, 54:310-314.

Özgür E., Afsar N., de Vrije T., Yücel M., Gündüz U., Claassen P.A.M., Eroglu I. (2010). Potential use of thermophilic dark fermentation effluents in photofermentative hydrogen production by Rhodobacter capsulatus. J Cleaner Prod, 18:S23-S28. 
Özgür E., \& Peksel, B. (2013). Biohydrogen production from barley straw hydrolysate through sequential dark and photofermentation. J Cleaner Prod, 52, 14-20.

Özkan E., Uyar B., Özgür E., Yücel M., Eroglu I. \& Gündüz U. (2012). Photofermentative hydrogen production using dark fermentation effluent of sugar beet thick juice in outdoor conditions. Int J Hydrogen Energy, 37(2):2044-2049.

Padovani G., Vaiciulyte S., Carlozzi P. (2016). $\mathrm{BioH}_{2}$ photoproduction by means of Rhodopseudomonas palustris sp. cultured in a lab-scale photobioreactor operated in batch, fed-batch and semi-continuous modes. Fuel, 166: 203-210.

Pattanamanee W., Choorit W., Kantachote D., Chisti Y. (2012). Repeated-batch production of hydrogen using Rhodobacter sphaeroides S10. Int J Hydrogen Energy, 37:15855-15866.

Pauss A., Samson R., Guiot S., Beauchemin C. (1990). Continuous measurement of dissolved $\mathrm{H}_{2}$ in an anaerobic reactor using a new hydrogen/air fuel cell detector. Biotechnol Bioeng, 35(5):492-501.

Ramos C., Buitrón G., Moreno-Andrade I, Chamy R. (2013). Effect of the initial total solids concentration and initial $\mathrm{pH}$ on the bio-hydrogen production from cafeteria food waste. Int $\mathrm{J}$ Hydrogen Energy, 37:13288-13295.

Redondas-Monteserrín, V. (2013). Obtención de hidrógeno mediante la fermentación oscura de residuos de comida y lactosuero. (PhD), Universidad de León, León España.

Redwood M., Paterson-Beedle M., \& Macaskie L. (2009). Integrating dark and light bio-hydrogen production strategies: towards the hydrogen economy. Rev Environ Sci and BioTechnol, 8(2):149-185.

Rees D. C., Akif F., Tezcan Haynes, C.A., Walton M. Y., Susana Andrade, . . Howard. (2005). Structural basis of biological nitrogen fixation. Phil. Trans R Soc A, 363: 971-984.

Rey F. E., Heiniger E. K., \& Harwood C. S. (2007). Redirection of Metabolism for Biological Hydrogen Production. Appl Environ Microbiol, 73(5):1665-1671.

Sargsyan H, Gabrielyan L, Hakobyan L, Trchounian Armen. (2015). Lightedark duration alternation effects on Rhodobacter sphaeroides growth, membrane properties and bio-hydrogen production in batch culture. Int J Hydrogen Energy, 40:4084-91.

Sarma S. J., Pachapur V., Brar S. K., Le Bihan Y. \& Buelna G. (2015). Hydrogen biorefinery: Potential utilization of the liquid waste from fermentative hydrogen production. Renew Sust Energ Rev, 50:942-951.

Seifert K., Waligorska M., Laniecki M. (2010). Hydrogen generation in photobiological process from dairy wastewater. Int J Hydrogen Energy, 35:9624-29.

Sharma L., \& Mallick, N. (2005). Accumulation of poly- $\beta$-hydroxybutyrate in Nostoc muscorum: regulation by $\mathrm{pH}$, light-dark cycles, $\mathrm{N}$ and $\mathrm{P}$ status and carbon sources. Bioresource Technol, 96(11):1304-1310.

Stadelman, W. J. (2000). Encyclopedia of food science and technology. New York: John Wiley \& Sons.

Studer I., Gonzalez, A., Contreras T., \& Trujano P. (2014). Energías renovables para la competitividad de México (pp. 31). México: Instituto Global para la Sostenibilidad de EGADE Business School, Tecnológico de Monterrey.

Takabatake H., Suzuki K., Ko, I.-B., \& Noike T. (2004). Characteristics of anaerobic ammonia removal by a mixed culture of hydrogen producing photosynthetic bacteria. Bioresource Technol, 95(2), 151-158.

Tao Y., He Y., Wu Y., Liu F., Li X., Zong W. \& Zhou Z. (2008). Characteristics of a new photosynthetic bacterial strain for hydrogen production and its application in wastewater treatment. Reviews in Environmental Science and Bio/Technology, 33(3), 963-973. 
Tawfik A., El-Bery H., Kumari S., Bux F. (2014). Use of mixed culture bacteria for photofermentive hydrogen of dark fermentation effluent. Bioresource Technol, 168:119-26.

Troesch W., Schmid-Staiger U., Zastrow A., Brucker F. (2003). Photobioreactor with improved supply of light by surface enlargement, wavelength shifter bars or light transport, states patent, us $6,509,188$ b1.

Uyar B. (2010). Biohidrogen production by photosynthetic bacteria in solar reactors. Photobioreactor design, process optimization, outdoor applications. U.S.A.: Lambert Academic Publishing.

Uyar B., Eroglu I., Yücel M., Gündüz U. \& Türker L. (2007). Effect of light intensity, wavelength and illumination protocol on hydrogen production in photobioreactors. Rev Environ Sci Biotechnol, 32(18):4670-4677.

Valdez-Vazquez I., \& Poggi-Varaldo H. M. (2009). Hydrogen production by fermentative consortia. Renew Sust Energ Rev, 13(5):1000-1013.

Valdez-Vazquez I., Ríos-Leal E., Esparza-García F., Cecchi F. \& Poggi-Varaldo H. M. (2005). Semicontinuous solid substrate anaerobic reactors for $\mathrm{H}_{2}$ production from organic waste: Mesophilic versus thermophilic regime. Int J Hydrogen Energy, 30(13-14):1383-1391.

Venkata Mohan S., Lenin Babu M., Venkateswar Reddy M., Mohanakrishna G. \& Sarma P. N. (2009). Harnessing of biohydrogen by acidogenic fermentation of Citrus limetta peelings: Effect of extraction procedure and pretreatment of biocatalyst. Int J Hydrogen Energy , 34(15):61496156.

Vignais P. M., Colbeau A., Willison J. C. \& Jouanneau Y. (1985). Hydrogenase, nitrogenase and hydrogen metabolism in photosynthetic bacteria. Adv Microb Physiol, 26:154-234.

Wakayama T, Nakada E, Asada Y, Miyake J. (2000). Effect of Light-dark Cycle on Bacterial Hydrogen Production by Rhodobacter sphaeroides RV. Appl. Biochem. Biotechnol, 84-86:431-40.

Wakayama T. \& Miyake J. (2002). Light shade bands for the improvement of solar hydrogen production efficiency by Rhodobacter sphaeroides RV. Int J Hydrogen Energy , 27(11-12):1495-1500.

Wu S. C., Liou S. Z., \& Lee C. M. (2012). Correlation between bio-hydrogen production and polyhydroxybutyrate (PHB) synthesis by Rhodopseudomonas palustris WP3-5. Bioresource Technol, 113: 44-50.

Xia A., Cheng J., Ding L., Lin R., Huang R., Zhou J. \& Cen K. (2013). Improvement of the energy conversion efficiency of Chlorella pyrenoidosa biomass by a three-stage process comprising dark fermentation, photofermentation, and methanogenesis. Bioresource Technol 146: 436443.

Yang H, Gou L, Liu F. (2010). Enhanced bio-hydrogen production from corncob by a two-step process: Dark- and photo-fermentation. Bioresource Technol, 101:2049-52.

Zhu H, Suzuky T, Tsygankov A, Asada Y, Miyake J. (1999). Hydrogen production from tofu wastewater by Rhodobacter sphaeroides immobilized in agar gels. Int J Hydrogen Energy, 24:305-10.

Zhu H., Parker W., Basnar R., Proracki A., Falletta P., Béland M. \& Seto P. (2008). Biohydrogen production by anaerobic co-digestion of municipal food waste and sewage sludges. Int $\mathrm{J}$ Hydrogen Energy , 33(14):3651-3659.

Zúñiga C, Morales M, Le Borgne S, Revah S. (2011). Production of poly-hydroxybutyrate (PHB) by Methylobacterium organophilum isolated from a methanotrophic consortium in a two-phase partition bioreactor. J Hazard Mater, 190:876-82. 


\section{APÉNDICE 1.}

Actividad A-1. Obtención y enriquecimiento de cultivos mixtos fotoheterótrofos de BPNS

Para la obtención de cultivos de BPNS se prepararon 8 columnas Winogradsky con fango de Río Apizaquito (Tlax), Planta de tratamiento de aguas residuales UAM-Iztapalapa ( D.F.), Cuatro ciénegas (Coahuila), Río Tizatlán (Tlax), Río Sta. Ursula (Tlax), Río. Yahuquemecán (Tlax), Laguna S. Cósme (Tlax), Planta de tratamiento de aguas residuales- San Juan Xalpa Iztapalapa (D.F).

De las ocho columnas de Winogradsky que se prepararon para obtener cultivos mixtos de BPNS, solo dos presentaron crecimiento de estas bacterias: río Santa Ursula y de la Planta de tratamiento de aguas residuales de Iztapalapa. Los cultivos fueron nombrados: IZT el cual fue obtenido de P. T. A. R. Iztapalapa (D.F) y TLX para el obtenido de Río Sta. Ursula (Tlax), ver tabla A-1 y figura A-2.

Tabla A-1. Obtención de cultivos mixtos de BPNS

\begin{tabular}{lr}
\hline Fuente de fango & Crecimiento de BPNS \\
\hline Río Apizaquito (Tlax) & Negativo \\
P.T.A.R. UAM ( D.F.) & Negativo \\
Cuatro ciénegas (Coahuila) & Negativo \\
Río Tizatlán (Tlax) & Negativo \\
Río Sta. Ursula (Tlax) & Negativo \\
Río. Yahuquemecán (Tlax) & Negativo \\
Laguna S. Cósme (Tlax) & Positivo (IZT) \\
\hline P. T. A. R. Iztapalapa (D.F)
\end{tabular}




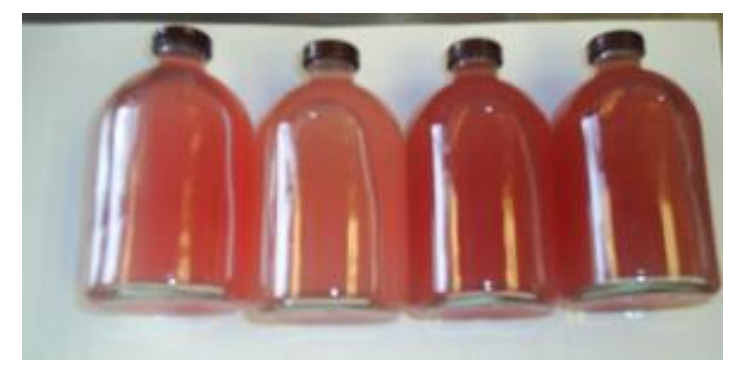

(a)

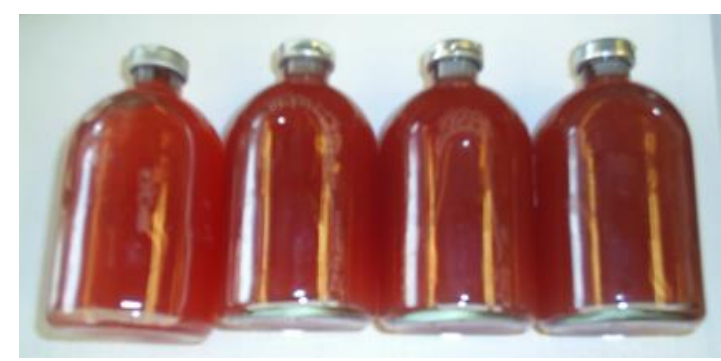

(b)

Figura A-1. Cultivo mixto IZT (a) y cultivo TLX (b) propagados en medio Pfennig.

\section{Actividad A-2. Selección del mejor cultivo productor de $\mathrm{H}_{2}$.}

Con los 2 cultivos mixtos obtenidos y propagados en medio Pfennig se realizó ensayos de producción de $\mathrm{H}_{2}$. Para ello se prepararon un experimento en botellas serológicas de $120 \mathrm{~mL}$ con DFE diluido 12 veces para que quedará a una concentración de $1 \mathrm{~g}$ butírico $\mathrm{L}^{-1}$ y $2.5 \mathrm{~g} \mathrm{DQO} \mathrm{L} \mathrm{L}^{-1}$ a pH 7 . Solo el cultivo IZT tuvo capacidad para producir hidrógeno.

\section{Actividad A-2. Selección de pH inicial}

Posteriormente se hizo un experimento para probar otros $2 \mathrm{pH}$ iniciales, 6.0 y 6.5 . En la figura A-2 se presentan las producciones acumuladas de hidrógeno para este experimento después de 25 días de 
operación. En ella se observa que el pH inicial de 6 no es apto, el pH inicial de 7 presentó ventaja sobre el de 6.5 .

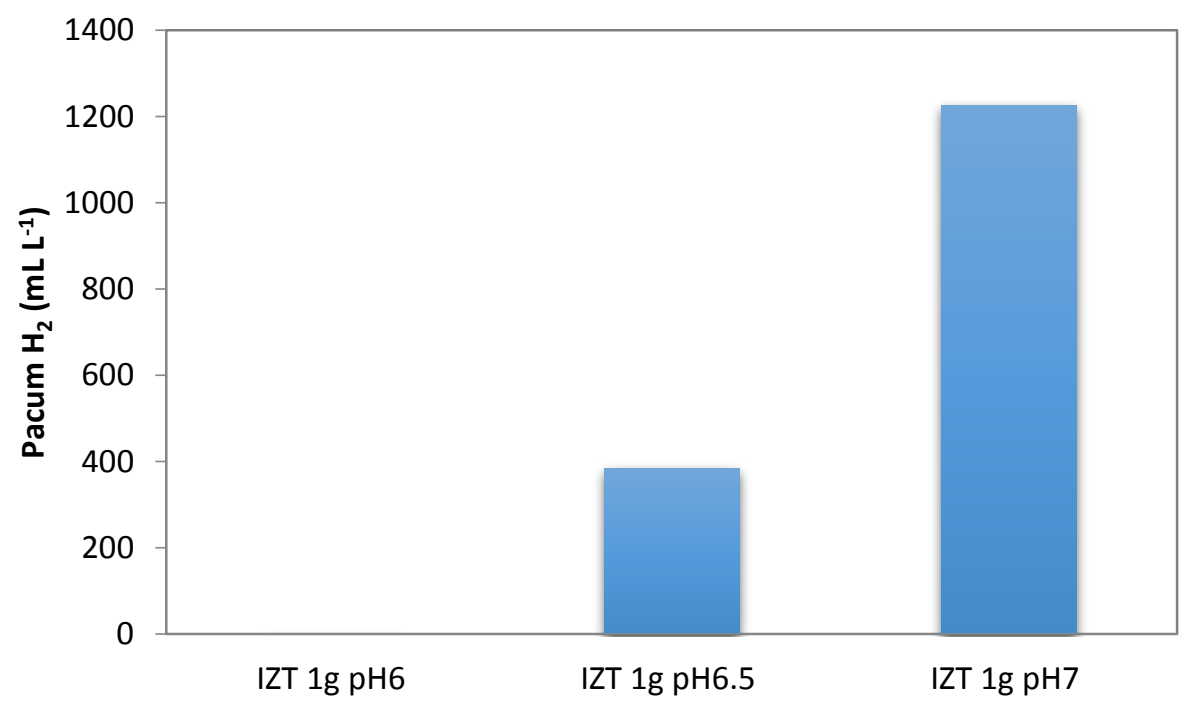

Figura A-2. Producción acumulada de hidrógeno para los tratamientos con diferente pH inicial.

\section{Actividad A-3. Selección de la concentración inicial de DFE}

Los experimentos iniciales se llevaron a cabo con DFE diluido 12 veces, pero con la finalidad de ver si era posible diluir menos se probaron otras dos concentraciones. Para ello se hicieron tres diluciones del DFE-UPIBI para que la concentración inicial de ácido butírico fuera de 1,2 y $3 \mathrm{~g} \mathrm{~L}$-1 , lo que implico diluir 12, 6 y 4 veces respectivamente.

En la tabla A-2 se muestran los resultados de esta actividad. La producción de hidrógeno por el tratamiento a $1 \mathrm{~g}$ butírico $\mathrm{L}^{-1}$ fue la más alta $\left(1530 \mathrm{~mL} \mathrm{H}_{2} \mathrm{~L}^{-1}\right)$, con 2 y $3 \mathrm{~g} \mathrm{~L}^{-1}$ fue insignificante. En el tratamiento con $1 \mathrm{~g}$ butírico el $\mathrm{pH}$ final se mantuvo cerca del $\mathrm{pH}$ inicial 7 , sin embargo para los tratamiento con 2 y $3 \mathrm{~g}$ butírico $\mathrm{L}^{-1} \mathrm{el} \mathrm{pH}$ final llego arriba de 9 y la concentración de biomasa fue más 
alta; probablemente estos dos acontecimientos fueron la causa de la baja producción de $\mathrm{H}_{2}$, el primero por la alta variación de pH y la segunda nos indica que una concentración más alta de biomasa pudo afectar la penetración y distribución de la luz dentro del cultivo.

Tabla A-2. Resultados para el experimento a diferentes concentraciones del DFE-UPIBI.

\begin{tabular}{lccc}
\hline Cultivo $\mathrm{IZT}$ & $1 \mathrm{~g}$ butírico $\mathrm{L}^{-1}$ & $2 \mathrm{~g}$ butírico $\mathrm{L}^{-1}$ & $3 \mathrm{~g}$ butírico $\mathrm{L}^{-1}$ \\
\hline Pacum $\mathrm{H}_{2}\left(\mathrm{~mL} \mathrm{H}_{2} \mathrm{~L}^{-1}\right)$ & $1530 \pm 77$ & $47 \pm 10$ & $18 \pm 8$ \\
$\mathrm{pH}$ final & 7.3 & 9.3 & 9.5 \\
Conc. SST $(\mathrm{mg} / \mathrm{L})$ & $730 \pm 14$ & $1260 \pm 28$ & $1440 \pm 57$ \\
Remoción de DQO & $77 \%$ & $11.8 \%$ & $6.8 \%$ \\
\hline
\end{tabular}

En la tabla A-3 se presenta la remoción de cada uno de los ácidos grasos volátiles para los diferentes tratamientos. El tratamiento que tuvo la mayor producción de $\mathrm{H}_{2}\left(\mathrm{IZT}-1 \mathrm{~g}\right.$ butírico $\left.\mathrm{L}^{-1}\right)$ presentó la remoción más alta de AGVs, $76.85 \%$. El tratamiento de 2g/L presento remoción de ácido propiónico y butírico, pero no para acético, en este caso produjo acético. Una situación similar se observa para el tratamiento de $3 \mathrm{~g} / \mathrm{L}$ en el que también se produce acético y un poco de butírico. Estos resultados indican que en los tratamientos donde no hubo producción de hidrógeno hubo un cambio en el modo de crecimiento del cultivo, el cual cambio de fotoheterótrofo a fermentativo. 
Tabla A-3. Remoción de AGVs para los tratamientos con 1, 2 y $3 \mathrm{~g}$ butírico $\mathrm{L}^{-1}$.

\begin{tabular}{lclll}
\hline AGV (1 g HBu/L) & Conc. Inicia (mg/L) & Conc. Final (mg/L) & Remoción (mg/L) & Remoción total \% \\
\hline Butírico & $1025 \pm 23$ & $161.85 \pm 9.4$ & 863.15 & $84.2 \%$ \\
Propiónico & $155 \pm 20$ & $41.66 \pm 0.5$ & 113.34 & $73.1 \%$ \\
Acético & $97 \pm 7.6$ & $92.08 \pm 1.3$ & 4.9 & $5.0 \%$ \\
& Total: 1277 & Total: 295.59 & Total:981.39 & Total: $76.85 \%$ \\
\hline AGV (2 g HBu/L) & Conc. Inicial (mg/L) & Conc. Final (mg/L) & Remoción (mg/L) & Remoción total \% \\
\hline Butírico & $1912.86 \pm 43$ & $637.89 \pm 75.7$ & 1274.97 & $66.65 \%$ \\
Propiónico & $289.57 \pm 37$ & $110.56 \pm 6.9$ & 179.01 & $61.8 \%$ \\
Acético & $181.4 \pm 14$ & $228.87 \pm 22.5$ & -47.47 & $-59.24 \%$ \\
& Total: 2383.83 & Total: 977.32 & Total: 1406.51 & Total: $59 \%$ \\
\hline AGV (3 g HBu/L) & Conc. Inicial (mg/L) & Conc. Final $(\mathrm{mg} / \mathrm{L})$ & Remoción (mg/L) & Remoción total \% \\
\hline Butírico & $2732.66 \pm 61$ & $2808.82 \pm 716.7$ & -76.16 & $-2.78 \%$ \\
Propiónico & $413.67 \pm 54$ & $326.73 \pm 10.9$ & 86.94 & $21.0 \%$ \\
Acético & $259.14 \pm 20$ & $646.77 \pm 270.5$ & -387.63 & $-149.6 \%$ \\
& Total: 3405.47 & Total: 3782.32 & Total: -376.85 & Total: $-11.06 \%$ \\
\hline
\end{tabular}




\section{APÉNDICE 2}




\title{
Hydrogen production by an enriched
} photoheterotrophic culture using dark fermentation effluent as substrate: Effect of flushing method, bicarbonate addition, and outdoor-indoor conditions

\author{
Virginia Montiel-Corona ${ }^{a}$, Sergio Revah ${ }^{b}$, Marcia Morales ${ }^{b, *}$ \\ a Doctorado en Biotecnología, División de Ciencias Biológicas y de la Salud, Universidad Autónoma Metropolitana- \\ Iztapalapa, San Rafael Atlixco 186, C.P. 09340, México, D.F., Mexico \\ ${ }^{\mathrm{b}}$ Departamento de Procesos y Tecnología, Universidad Autónoma Metropolitana-Cuajimalpa, Avenida Vasco de \\ Quiroga 4871, Colonia Santa Fe, Delegación Cuajimalpa de Morelos, C.P. 05348, México, D.F., Mexico
}

\section{A R T I C L E I N F O}

Article history: Received 19 December 2014

Received in revised form 7 May 2015

Accepted 11 May 2015

Keywords:

Biohydrogen

Photo-fermentation

Reduced pressure

Photoheterotrophic culture

Rhodobacter capsulatus

Outdoor

\begin{abstract}
A B S T R A C T
This work compares the photo-fermentative hydrogen production by an enriched photoheterotrophic culture (IZT) and by Rhodobacter capsulatus under outdoor or indoor conditions using dark fermentation effluent (DFE) as substrate, and argon, $\mathrm{CO}_{2}$ and reduced pressure for flushing the headspace and bicarbonate as electron sink.

The highest $\mathrm{H}_{2}$ production (1478 $\pm 17 \mathrm{~mL} \mathrm{H}_{2} \mathrm{~L}^{-1}$ with $89 \% \mathrm{COD}$ removal) was obtained under indoor conditions by the IZT culture with reduced pressure and $250 \mathrm{mg} \mathrm{L}^{-1}$ of $\mathrm{NaHCO}_{3}$, followed by $\mathrm{R}$. capsulatus $\left(1252 \pm 20 \mathrm{~mL} \mathrm{H}_{2} \mathrm{~L}^{-1}\right.$ with $65 \% \mathrm{COD}$ removal) under the same conditions. Outdoor $\mathrm{H}_{2}$ production was reduced to $883 \pm 4$ and $866 \pm 46 \mathrm{~mL} \mathrm{H}_{2} \mathrm{~L}^{-1}$ with IZT culture and R. capsulatus, respectively. Poly-3-hydroxybutyrate accumulation was up to $5 \%$ for IZT culture and $29 \%$ for R. capsulatus.

Enhancement on hydrogen production using reduced pressure and DFE along with the achieved COD removal and poly-3-hydroxybutyrate accumulation can contribute to abate the costs of hydrogen production.

Copyright $\odot$ 2015, Hydrogen Energy Publications, LLC. Published by Elsevier Ltd. All rights
\end{abstract}

reserved.

\section{Introduction}

Fermentative hydrogen production from wastes is an alternative to get renewable energy and manage organic waste in an environmentally friendly way. Bio-hydrogen production can be achieved by either dark fermentation with fermentative bacteria or photo-fermentation by purple non-sulfur bacteria (PNSB). Dark fermentation has faster metabolic rates and lower operational requirements [1] but has low $\mathrm{H}_{2}$

\footnotetext{
* Corresponding author. Universidad Autónoma Metropolitana Cuajimalpa, Avenida Vasco de Quiroga 4871, Colonia Santa Fe, Delegación Cuajimalpa de Morelos, C.P. 05348, México, D.F., Mexico. Tel.: +52555814 65 00; fax: +52 5558046407.

E-mail address: mmorales 6 correo.cua.uam. mx (M. Morales). http://dx.doi.org/10.1016/j.ijhydene.2015.05.067

0360-3199/Copyright @ 2015, Hydrogen Energy Publications, LLC. Published by Elsevier Ltd. All rights reserved.
} 
yields due to the incomplete degradation of wastes and to the accumulation of acids, limiting the yield to less than $20 \%$ of the theoretical value of $12 \mathrm{~mol} \mathrm{H}_{2} \mathrm{~mol}^{-1}$ glucose. The volatile fatty acids (VFAs) accumulated during the dark-fermentation can be further converted to $\mathrm{H}_{2}$ with near stoichiometric efficiency and yields up to $8 \mathrm{~mol} \mathrm{H}_{2} \mathrm{~mol}^{-1}$ glucose can be obtained with two-stage process comprising both dark and photofermentation [1].

Photoheterotrophichydrogen production by PNSB typically uses pure cultures under sterile conditions [2] with model substrates such as succinate, lactate, butyrate, malate, acetate and propionate [2-4] but recently more complex substrates such as dark fermentation effluents (DFE) of corncob, potato steam peel, cheese whey, molasses, barley straw hydrolysate and others [5-9] have been used. Enriched PNSB cultures obtained from wastewater could be interesting since they can be metabolically more versatile and more effective using complex substrates than pure cultures [2], however, enriched photoheterotrophic cultures with complex substrates have not been broadly used.

Hydrogen production by PNSB is associated with the nitrogenase that promotes the conversion of dinitrogen gas and protons to ammonia and $\mathrm{H}_{2}$. However, nitrogenase is inhibited by oxygen $[10,11]$ and therefore it is necessary to keep anaerobic conditions. Low $\mathrm{H}_{2}$ partial pressure also needs to be maintained in the headspace because hydrogenases (such as NiFe-hydrogenase) may re-oxidize the produced

hydrogen into protons and electrons [10]. Argon has been often used to flush both oxygen and nitrogen and to keep low $\mathrm{H}_{2}$ partial pressure in the reactors but it increases production costs and hinders $\mathrm{H}_{2}$ purification. Some reports have alternatively tested reduced pressure and $\mathrm{CO}_{2}$ for flushing the headspace and maintaining low $\mathrm{H}_{2}$ partial pressure in dark fermentation $[12,13]$, but in photofermentation the information is scarce.

Photofermentative outdoor $\mathrm{H}_{2}$ production is affected mainly by solar light energy and by temperature. These non-controlled variables regulate photosynthetic activity and therefore daily (day/night cycle), seasonal and geographical variations greatly influence growth and the amount of $\mathrm{H}_{2}$ produced. Therefore it is important to evaluate the effect of such conditions on potential $\mathrm{H}_{2}$ producing cultures.

It is also known that PNSB need an electron acceptor when the substrate is more reduced than cell components. It has been demonstrated that the presence of carbonate ion in PNSB growth media enhances VFAs uptake, since carbonate serves as an excess electron sink for propionic and butyric acid substrates which are more reduced than the cellular components $[14,15]$. Despite this evidence and that butyric acid is one of the major by-products of dark fermentation, carbonate has not been used to improve photofermentative hydrogen production from DFE rich in butyric or propionic acid.

PNSB can accumulate poly-3-hydroxybutyrate (PHB) as energy storage material when they are faced with suboptimal environments. The amount of PHB that PNSB can accumulate depends on the PNSB strains, substrate and their metabolic pathways. For example, Rhodobacter sphaeroides uses the Ethylmalonyl-CoA pathway to assimilate acetate.
This pathway shares common elements with that used for PHB biosynthetic pathway enabling $R$. sphaeroides to accumulate high PHB levels ( $80 \%$ of its cell dry weight) [16]. The acetate assimilation pathway in Rhodobacter capsulatus is through the citramalate cycle [17]. In Rhodopseudomonas palustris, the acetate assimilation goes through the glyoxylate cycle, Wu et al. [18] reported that strain WP3-5 cannot utilize malate and lactate to produce PHB and only synthesizes it on acetate and propionate accumulating 10\% PHB. PHB accumulation in PNSB can compete with $\mathrm{H}_{2}$ production for electrons and energy distribution, so it is important to determine PHB accumulation to evaluate hydrogen production loss [18]. As PHB is a valuable biodegradable polymer [17], it may also be recovered as a by-product from the hydrogen production process.

This work explores hydrogen production by both an enriched photoheterotrophic culture and R. capsulatus under non-sterile conditions using a real dark fermentation effluent as substrate. Argon, reduced pressure and $\mathrm{CO}_{2}$ were tested to keep anaerobic conditions and lower $\mathrm{H}_{2}$ partial pressure. The use of $\mathrm{NaHCO}_{3}$ was also explored to enhance $\mathrm{H}_{2}$ production. The experiments were performed under indoor conditions with continuous illumination or outdoors with natural light/ dark cycles. Chemical oxygen demand (COD) removal and PHB accumulation were also measured to estimate potential benefits such as production of added-value compound and waste management.

\section{Materials and methods}

\section{IZT culture and R. capsulatus}

The photoheterotrophic culture was obtained by using a Winogradsky column prepared with activated sludge collected at the wastewater treatment plant "Cerro de la Estrella" located in the San Juan Xalpa, Iztapalapa municipality in México City.

Winogradsky columns contained $800 \mathrm{~mL}$ of activated sludge; $12.5 \mathrm{~g} \mathrm{CaSO}_{4}, 12.5 \mathrm{~g} \mathrm{CaCO}_{3}$ and $25 \mathrm{~g}$ of sawdust were added to a glass cylinder of $4 \mathrm{~cm}$ diameter and $1 \mathrm{~L}$ capacity. The column was placed next to a window at room temperature $\left(25-28^{\circ} \mathrm{C}\right)$ for 15 days; after that period, a $5 \mathrm{~mL}$ sample of the reddish band below the surface of the water column was collected and transferred to $120 \mathrm{~mL}$ serological bottles with $85 \mathrm{~mL}$ of modified Pfennig medium not containing either sulfur source nor dextrose to avoid proliferation of fermentative or purple sulfur organisms. Argon was used as gas phase to maintain anaerobic conditions during this enrichment stage. These bottles were incubated at $3 \mathrm{kLux}$ in a photoregulated chamber using halogen and LEDS lamps, the temperature was maintained at $30^{\circ} \mathrm{C}$.

A total of six subsequent subcultures were done every two weeks, transferring $5 \mathrm{~mL}$ of the reddish culture into $85 \mathrm{~mL}$ of fresh mineral medium and incubating it under the abovementioned conditions. The resulting enriched culture was the photoheterotrophic IZT culture employed in this study.

R. capsulatus ATCC 17015 was obtained from the ATCC Bacteriology Collection. It was also cultivated in modified Pfennig medium. 


\section{Mineral medium}

The culture medium utilized for enrichment was the modified Pfennig medium containing (in $\mathrm{g} \mathrm{L}^{-1}$ ): yeast extract, 0.10 ; $\mathrm{NH}_{4} \mathrm{Cl}, 0.350 ; \mathrm{KH}_{2} \mathrm{PO}_{4}, 0.350 ; \mathrm{MgSO}_{4}, 0.514 ; \mathrm{KCl}, 0.350$; $\mathrm{CaCl}_{2} \cdot 2 \mathrm{H}_{2} \mathrm{O}, 0.257$; and $0.40 \mathrm{~mL}$ B12 vitamin solution (10 mg in $100 \mathrm{~mL} \mathrm{H}_{2} \mathrm{O}$ ), trace element solution, $18 \mathrm{~mL} ; \mathrm{NaHCO}_{3}, 1.51 \mathrm{~g}$; and acetic acid, $20 \mathrm{mM}$ and butyric acid, $15 \mathrm{mM}$. The medium was autoclaved at $121^{\circ} \mathrm{C}$ for $15 \mathrm{~min}$, after that $\mathrm{pH}$ was adjusted to 7 , and was poured in $120 \mathrm{~mL}$ vials using $\mathrm{Ar}$ to maintain anaerobic conditions. Trace element solution contained (in $\mathrm{g} \mathrm{L}^{-1}$ ): EDTA, 0.5; $\mathrm{FeSO}_{4} \cdot 7 \mathrm{H}_{2} \mathrm{O}, 0.2 ; \mathrm{ZnSO}_{4} \cdot 7 \mathrm{H}_{2} \mathrm{O}, 0.01$; $\mathrm{MnCl}_{2} \cdot 4 \mathrm{H}_{2} \mathrm{O}, 0.003 ; \mathrm{H}_{3} \mathrm{BO}_{3}, 0.03 ; \mathrm{CoCl}_{2} \cdot 6 \mathrm{H}_{2} \mathrm{O}, 0.03 ; \mathrm{CuCl}_{2} \cdot 2 \mathrm{H}_{2} \mathrm{O}$, $0.001 ; \mathrm{NiCl}_{2} \cdot 6 \mathrm{H}_{2} \mathrm{O}, 0.002$ and $\mathrm{NaMoO}_{4} \cdot 2 \mathrm{H}_{2} \mathrm{O}, 0.003$.

\section{Hydrogen production by batch photofermentation}

\section{Experimental design}

The influence of four factors on the hydrogen production was evaluated in a full factorial design with their respective levels: inoculum type factor (with two levels: $R$. capsulatus and IZT culture); headspace flushing method factor (with three levels: $\mathrm{Ar}, \mathrm{CO}_{2}$, and reduced pressure); $\mathrm{NaHCO}_{3}$ addition factor (with 0,250 and $500 \mathrm{mg} \mathrm{L}^{-1}$ ); and incubation conditions factor (indoor and outdoor). A factorial design was chosen to identify the factors having higher impact on the response variables. The response variables were cumulative production of hydrogen ( $\left(\right.$ accum $\mathrm{H}_{2}$ ) in $\mathrm{mL} \mathrm{L}^{-1}$ broth, substrate conversion efficiency, SCE (\%), VFAs removal (\%), COD removal (\%) and PHB accumulation (gPHB gdw ${ }^{-1}$ ). The SCE (\%) was calculated as the ratio of the experimentally produced hydrogen and the theoretical value $\left(4 \mathrm{~mol} \mathrm{H}_{2} \mathrm{~mol}^{-1}\right.$ acetate, $7 \mathrm{~mol} \mathrm{H}_{2} \mathrm{~mol}^{-1}$

propionate, $10 \mathrm{~mol} \mathrm{H}_{2} \mathrm{~mol}^{-1}$ butyrate). Statistical analysis for main effects and graph plotting was performed using DesignExpert software (v7.1.5). ANOVA through Fisher's test was used to evaluate the effect of independent variables on the response and significant results were identified by a $p$-value of $<0.05$. Residual analysis was carried out to confirm that the assumptions for the ANOVA were met. Additionally, the "onefactor-effect" graphs were built for each tested factor.

Dark fermentation effluent

The substrate was a DFE from fruit and vegetable wastes. The detailed composition of this effluent is given in Table 1.

\section{Batch experiments}

Experiments were carried out in $120 \mathrm{~mL}$ serological bottles with $69 \mathrm{~mL}$ of tap water and $7 \mathrm{~mL}$ of non-sterile DFE previously centrifuged at $4000 \mathrm{rpm}$ for $10 \mathrm{~min}$. The diluted effluent was amended with $\mathrm{NaHCO}_{3}\left(0,250\right.$ or $\left.500 \mathrm{mg} \mathrm{L}^{-1}\right)$ and the $\mathrm{pH}$ adjusted to 7.0 with $0.5 \mathrm{M} \mathrm{NaOH}$. Then, $4.5 \mathrm{~mL}$ of a $420 \mathrm{mM}$ phosphate buffer solution was added.

The bottles were fitted with rubber stoppers, and either $\mathrm{Ar}$ or $\mathrm{CO}_{2}$ was used to flush the air in the headspace. In experiments at reduced pressure $(8.5 \mathrm{~cm} \mathrm{Hg})$, the air in headspace was removed through a needle inserted in the rubber stopper and connected to a vacuum pump.

All bioreactors were inoculated with $5 \mathrm{~mL}$ of the either $\mathrm{R}$. capsulatus or IZT culture (equivalent to $0.01 \mathrm{~g} \mathrm{~L}^{-1}$ protein) and initially operated under indoor static incubation conditions
Table 1 - Composition of the DFE used as substrate in photo-fermentation assays.

Component

Concentration

\section{Butyric acid}

Propionic acid

Acetic acid

$\mathrm{NH}_{4}$

TOC

TN

$\mathrm{C} / \mathrm{N}$

COD

COD total

TS

vS

$11.61 \pm 0.26\left(\mathrm{~g} \mathrm{~L}^{-1}\right)$

$1.76 \pm 0.23\left(\mathrm{~g} \mathrm{~L}^{-1}\right)$

$1.01 \pm 0.08\left(\mathrm{~g} \mathrm{~L}^{-1}\right)$

$780 \pm 32.5\left(\mathrm{mg} \mathrm{L}^{-1}\right)$

$9600 \pm 613\left(\mathrm{mg} \mathrm{L}^{-1}\right)$

$903 \pm 56\left(\mathrm{mg} \mathrm{L}^{-1}\right)$

10.63

$30.6 \pm 0.4\left(\mathrm{~g} \mathrm{~L}^{-1}\right)$

$55.24\left(\mathrm{~g} \mathrm{~L}^{-1}\right)$

$313 \pm 9\left(\mathrm{mg} \mathrm{L}^{-1}\right)$

$253 \pm 19\left(\mathrm{mg} \mathrm{L}^{-1}\right)$

COD total includes the contribution by VFAs and by other organic compounds. TOC: Total organic carbon, TN: Total nitrogen, $\mathrm{C} / \mathrm{N}$ : ratio carbon/nitrogen, TS: Total solids, VS: Volatile solids.

and continuous illumination with LEDS and halogen lamps to reach $3 \mathrm{kLux}$ and $30 \pm 3^{\circ} \mathrm{C}$. After 5 days, half of the reactors were placed outdoors in a greenhouse shade cloth. Each assay was done in duplicate. The outdoor experiments were performed during summer in México City.

Depending on the treatment, and to avoid $\mathrm{H}_{2}$ uptake by hydrogenases, the headspace pressure was lowered to $8.5 \mathrm{~cm} \mathrm{Hg}$, or flushed with $\mathrm{Ar}$ or $\mathrm{CO}_{2}$ every 3 days, or when the headspace pressure increased by biogas generation. The experiments concluded when $\mathrm{H}_{2}$ production ceased.

Specific hydrogen production rate was obtained by fitting experimental data to the Gompertz equation.

\section{Analytical methods}

The $\mathrm{H}_{2}$ content in the bioreactors headspace was determined by TCD gas chromatography (Gow Mac model 580) with a silica-gel $60 / 80$ column, $180 \times 1 / 8 \times 0.0850$, with $\mathrm{N}_{2}$ as a carrier gas. The injector, column, and detector temperatures were 75 , 30 , and $120^{\circ} \mathrm{C}$, respectively; and the detector current was $85 \mathrm{~mA}$. The produced $\mathrm{H}_{2}$ is reported at normal temperature and pressure (NTP).

Biomass concentration as protein content was measured by the Lowry method with the BIO-RAD DC protein assay kit. The PHB content was determined according to Zúniga et al. [19]. The VFAs composition was analyzed by FID gas chromatography (Hewlett Packard 5890 Series II) using an AT1000 capillary column $(15 \mathrm{~m} \times 0.53 \mathrm{~mm} \mathrm{ID}, 1.23 \mu \mathrm{m}$ film). The injector and detector temperatures were both $200^{\circ} \mathrm{C}$. The oven temperature was initially set at $80^{\circ} \mathrm{C}$ for $2 \mathrm{~min}$ and increased from 80 to $200{ }^{\circ} \mathrm{C}$ at a rate of $15^{\circ} \mathrm{C} \mathrm{min}^{-1}$, and held for $1 \mathrm{~min}$. The carrier gas flow was $6 \mathrm{~mL} \mathrm{~min}^{-1}$. The liquor samples were first filtered through a $0.2 \mu \mathrm{m}$ membrane and then acidified with hydrochloric acid, finally injected to measure the concentration of free acids.

The soluble total organic carbon (TOC) of the dark fermentation effluent was determined with a Shimadzu TOC5000 analyzer. Volatile solids (VS) were determined by standard method (APHA-AWWA-WPCF, 1992). Nitrogen from ammonia was quantified with a $\mathrm{HACH}$ NI-8 test kit. The light intensity was measured with a light meter (Extech Instruments 407026sp model 2.2, USA). 


\section{Results and discussion}

Table 2 shows the results of the full experimental design to evaluate the effect of the inoculum type, headspace flushing method, $\mathrm{NaHCO}_{3}$ addition and incubation conditions (indoor and outdoor) on Paccum $\mathrm{H}_{2}, \mathrm{COD}$ removal (\%), accumulated PHB $\left(\mathrm{mg} \mathrm{gdw}^{-1}\right)$, SCE (\%) and VFAs removal (\%). From these data an analysis of variance (ANOVA) was performed to evaluate the statistical significance of the above-mentioned factors on Paccum $\mathrm{H}_{2}, \mathrm{COD}$ removal (\%) and accumulated PHB ( $\mathrm{mg} \mathrm{gdw}^{-1}$ ), and the results are shown in Table 3. The F-value obtained for the analysis indicated that the model was significant, with a $p$ value $<0.01 \%$. The $p$-values are a measure of the statistical significance of each variable; low $p$-values correspond to a high statistical significance of the variables within the model. In this study, $p$-values less than 0.05 were accepted to be significant. A discussion for each factor is presented in the following sections.

\section{Hydrogen production}

Effect of inoculum on phototrophic hydrogen production The analysis of variance shown in Table 3 indicates that Paccum $\mathrm{H}_{2}$ was significantly affected $(p<0.05)$ by all factors (headspace flushing method $(p<0.0001)$, bicarbonate concentration $(p<0.0001)$, and incubation conditions $(p<0.0001)$ ) except for the culture type $(p=0.66)$. In order to visualize these trends, Fig. 1 shows the average of Paccum $\mathrm{H}_{2}$ for each level of

trends, Fig. 1 shows the average of Paccum $\mathrm{H}_{2}$ for each level of the evaluated factors. The first two columns in Fig. 1 correspond to "one-factor-effect" graph for inoculum. As can be seen, the values for R. capsulatus, $751 \mathrm{~mL} \mathrm{H}_{2} \mathrm{~L}^{-1}$, and the IZT culture, $767 \mathrm{~mL} \mathrm{H}_{2} \mathrm{~L}^{-1}$, were similar. They have the same capacity to produce hydrogen and also generated similar biomass content, $0.2 \mathrm{~g}$ protein $\mathrm{L}^{-1}$ on average.

The maximum Paccum $\mathrm{H}_{2}, 1478 \pm 17 \mathrm{~mL} \mathrm{H}_{2} \mathrm{~L}^{-1}$ with an SCE of $48 \%$, was achieved by the IZT culture with $250 \mathrm{mg} \mathrm{NaHCO} \mathrm{L}^{-1}$, reduced pressure and indoor conditions (Fig. 2 and Table 2), the maximum production rate was $6.5 \mathrm{~mL} \mathrm{H}_{2} \mathrm{~L}^{-1} \mathrm{~h}^{-1}$ and most of the hydrogen production (91\%) was reached in the first 18 days.

Biomass increased up to $0.3 \mathrm{~g}$ protein $\mathrm{L}^{-1}$ in the first week possibly correlated to the initial nitrogen content of the diluted DFE $\left(0.75 \mathrm{mg} \mathrm{N} \mathrm{L}^{-1}\right)$. Hydrogen was produced since the initial stages of fermentation and its production was partially associated to growth. It can be noticed that butyric acid was consumed during the first 11 days in the exponential growth phase. Although no VFAs were detected, $\mathrm{H}_{2}$ production continued for 10 days decaying thereafter. The decrease in $\mathrm{H}_{2}$ production rates in the later phase of the fermentation was due to the consumption of the remaining and more recalcitrant organic matter once the easily degradable VFAs from DFE were depleted.

The DFE had $2.6 \mathrm{~g} \mathrm{COD} \mathrm{L}^{-1}$ at the beginning of the experiments and the VFAs content was $1 \mathrm{gL}^{-1}$ butyric acid, $0.15 \mathrm{gL}^{-1}$ propionic and $0.1 \mathrm{~g} \mathrm{~L}^{-1}$ acetic acid. In the case of IZT culture, the propionic and acetic acids were fully consumed in three days, while it took over 10 days for the butyric acid; at this time, the COD consumption was $68 \%$, but rose up to $89 \%$ towards the end of the process. R. capsulatus followed a similar kinetic behavior and produced $1252 \pm 20 \mathrm{~mL} \mathrm{H}_{2} \mathrm{~L}^{-1}$ corresponding to an SCE of $40 \%$ that was $8 \%$ lower than IZT culture.

sponding to an SCE of $40 \%$ that was $8 \%$ lower than IZT culture. An important fraction, $94 \%$ of the $\mathrm{H}_{2}$ production was reached in the first 15 days with a maximum production rate of $5.7 \mathrm{~mL} \mathrm{H}_{2} \mathrm{~L}^{-1} \mathrm{~h}^{-1}$ (Fig. 3 and Table 2).

\begin{tabular}{|c|c|c|c|c|c|c|c|c|c|c|}
\hline \multirow{2}{*}{$\begin{array}{l}\text { Response variable } \\
\text { Culture }\end{array}$} & \multicolumn{2}{|c|}{$\begin{array}{l}\text { Paccum } \mathrm{H}_{2} \\
\left(\mathrm{~mL} \mathrm{~L}^{-1}\right)\end{array}$} & \multicolumn{2}{|c|}{$\begin{array}{c}\text { Substrate conversion } \\
\text { efficiency }(\%)\end{array}$} & \multicolumn{2}{|c|}{$\begin{array}{c}\text { VFAs removal } \\
(\%) \\
\end{array}$} & \multicolumn{2}{|c|}{$\begin{array}{c}\text { COD removal } \\
(\%) \\
\end{array}$} & \multicolumn{2}{|c|}{$\begin{array}{c}\text { PHB accumulation } \\
\left(\mathrm{mg} \mathrm{gdw}^{-1}\right)\end{array}$} \\
\hline & R. caps & IZT & R. caps & IZT & R. caps & IZT & R. caps & IZT & R. caps & IZT \\
\hline \multicolumn{11}{|l|}{ Indoor treatments } \\
\hline $\mathrm{Ar}-\mathrm{N}$ & $320 \pm 423$ & $830 \pm 23$ & $10 \pm 14$ & $27 \pm 1$ & $63 \pm 3$ & $72 \pm 1$ & $47 \pm 3$ & $72 \pm 0$ & $68 \pm 4$ & $165 \pm 13$ \\
\hline $\mathrm{Ar}-\mathrm{M}$ & $1032 \pm 33$ & $1120 \pm 49$ & $33 \pm 1$ & $36 \pm 2$ & $100 \pm 0$ & $90 \pm 0$ & $58 \pm 1$ & $78 \pm 1$ & $98 \pm 2$ & $63 \pm 8$ \\
\hline $\mathrm{Ar}-\mathrm{H}$ & $1003 \pm 1$ & $850 \pm 50$ & $32 \pm 0$ & $27 \pm 2$ & $100 \pm 0$ & $81 \pm 0$ & $53 \pm 1$ & $72 \pm 1$ & $89 \pm 4$ & $69 \pm 4$ \\
\hline $\mathrm{CO}_{2}-\mathrm{N}$ & $877 \pm 427$ & $553 \pm 29$ & $28 \pm 14$ & $18 \pm 1$ & $100 \pm 0$ & $88 \pm 0$ & $57 \pm 0$ & $54 \pm 0$ & $137 \pm 12$ & $105 \pm 6$ \\
\hline $\mathrm{CO}_{2}-\mathrm{M}$ & $1105 \pm 15$ & $795 \pm 38$ & $36 \pm 0$ & $26 \pm 1$ & $100 \pm 0$ & $94 \pm 0$ & $65 \pm 1$ & $62 \pm 1$ & $79 \pm 4$ & $48 \pm 6$ \\
\hline $\mathrm{CO}_{2}-\mathrm{H}$ & $1088 \pm 38$ & $469 \pm 53$ & $35 \pm 1$ & $15 \pm 2$ & $100 \pm 0$ & $92 \pm 0$ & $32 \pm 0$ & $48 \pm 0$ & $19 \pm 1$ & $51 \pm 1$ \\
\hline RP-N & $799 \pm 480$ & $1127 \pm 10$ & $26 \pm 15$ & $36 \pm 0$ & $100 \pm 0$ & $100 \pm 0$ & $73 \pm 1$ & $89 \pm 0$ & $38 \pm 3$ & $51 \pm 13$ \\
\hline RP-M & $1252 \pm 20$ & $1478 \pm 17$ & $40 \pm 1$ & $48 \pm 1$ & $100 \pm 0$ & $100 \pm 0$ & $65 \pm 0$ & $89 \pm 1$ & $53 \pm 3$ & $27 \pm 1$ \\
\hline RP-H & $1249 \pm 61$ & $1289 \pm 47$ & $40 \pm 2$ & $41 \pm 2$ & $100 \pm 0$ & $98 \pm 0$ & $66 \pm 2$ & $86 \pm 2$ & $47 \pm 4$ & $36 \pm 2$ \\
\hline \multicolumn{11}{|l|}{ Outdoor treatments } \\
\hline $\mathrm{Ar}-\mathrm{N}$ & $294 \pm 195$ & $44 \pm 40$ & $9 \pm 6$ & $1 \pm 1$ & $63 \pm 3$ & $43 \pm 1$ & $29 \pm 1$ & $40 \pm 2$ & $84 \pm 5$ & $144 \pm 17$ \\
\hline $\mathrm{Ar}-\mathrm{M}$ & $467 \pm 9$ & $632 \pm 38$ & $15 \pm 0$ & $20 \pm 1$ & $100 \pm 0$ & $68 \pm 1$ & $60 \pm 0$ & $55 \pm 1$ & $414 \pm 5$ & $47 \pm 4$ \\
\hline $\mathrm{Ar}-\mathrm{H}$ & $512 \pm 0$ & $512 \pm 6$ & $16 \pm 0$ & $16 \pm 0$ & $100 \pm 0$ & $60 \pm 0$ & $47 \pm 11$ & $49 \pm 0$ & $386 \pm 22$ & $47 \pm 4$ \\
\hline $\mathrm{CO}_{2}-\mathrm{N}$ & $18 \pm 5$ & $279 \pm 3$ & $1 \pm 0$ & $9 \pm 0$ & $49 \pm 0$ & $51 \pm 1$ & $24 \pm 2$ & $40 \pm 1$ & $60 \pm 3$ & $39 \pm 5$ \\
\hline $\mathrm{CO}_{2}-\mathrm{M}$ & $226 \pm 2$ & $523 \pm 38$ & $7 \pm 0$ & $17 \pm 1$ & $69 \pm 0$ & $76 \pm 1$ & $32 \pm 0$ & $53 \pm 2$ & $18 \pm 5$ & $39 \pm 5$ \\
\hline $\mathrm{CO}_{2}-\mathrm{H}$ & $182 \pm 9$ & $293 \pm 32$ & $6 \pm 0$ & $9 \pm 1$ & $72 \pm 1$ & $63 \pm 0$ & $57 \pm 2$ & $40 \pm 1$ & $145 \pm 2$ & $49 \pm 7$ \\
\hline RP-N & $417 \pm 170$ & $861 \pm 44$ & $13 \pm 5$ & $28 \pm 1$ & $78 \pm 1$ & $96 \pm 1$ & $71 \pm 1$ & $84 \pm 4$ & $44 \pm 5$ & $15 \pm 5$ \\
\hline RP-M & $866 \pm 46$ & $883 \pm 4$ & $28 \pm 1$ & $28 \pm 0$ & $100 \pm 0$ & $95 \pm 2$ & $68 \pm 4$ & $80 \pm 1$ & $299 \pm 9$ & $42 \pm 4$ \\
\hline RP-H & $812 \pm 32$ & $610 \pm 11$ & $26 \pm 1$ & $20 \pm 0$ & $100 \pm 0$ & $77 \pm 0$ & $68 \pm 1$ & $61 \pm 3$ & $265 \pm 14$ & $48 \pm 25$ \\
\hline
\end{tabular}


Table 3 - Summary of ANOVA results for the response variables Paccum $\mathrm{H}_{2}$, COD removal and PHB accumulation.

\begin{tabular}{|c|c|c|c|c|c|c|}
\hline \multirow{2}{*}{$\begin{array}{l}\text { Response variable } \\
\text { Factors }\end{array}$} & \multicolumn{2}{|c|}{ Paccum $\mathrm{H}_{2}$} & \multicolumn{2}{|c|}{ PHB accumulation } & \multicolumn{2}{|c|}{ COD removal } \\
\hline & F-value & $p$-value & F-value & $p$-value & F-value & $p$-value \\
\hline Model & 67.68 & $<0.0001$ & 5.31 & 0.0002 & 27.8 & $<0.0001$ \\
\hline Inoculum type & 0.20 & 0.6600 & 12.09 & 0.0009 & 19.62 & $<0.0001$ \\
\hline Headspace Flushing Method & 66.79 & $<0.0001$ & 5.64 & 0.0056 & 55.03 & $<0.0001$ \\
\hline Bicarbonate concentration & 23.68 & $<0.0001$ & 0.52 & 0.5962 & 4.66 & 0.0130 \\
\hline Incubation conditions & 210.95 & $<0.0001$ & 6.37 & 0.0142 & 25.35 & $<0.0001$ \\
\hline
\end{tabular}

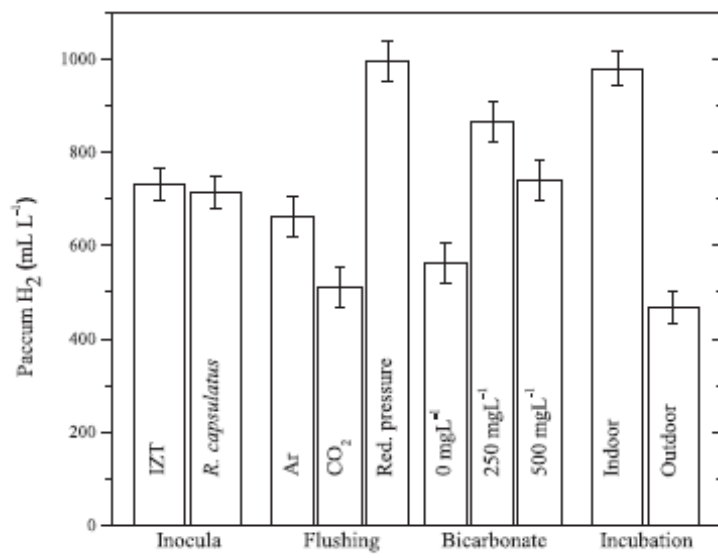

Fig. 1 - Summary of the four "one-factor effect" graphs produced in the ANOVA statistical analysis. Each group of bars denotes the effect of changing the level of a single factor (inocula, headspace flushing method, bicarbonate concentration, and, incubation conditions) on average cumulative production of hydrogen.

Compared with published data of hydrogen production, results with IZT culture were better than those obtained from a photoheterotrophic consortium from sediments of a Brazilian lagoon by Aparecida Loss et al. [20] with a Paccum $\mathrm{H}_{2}$ of

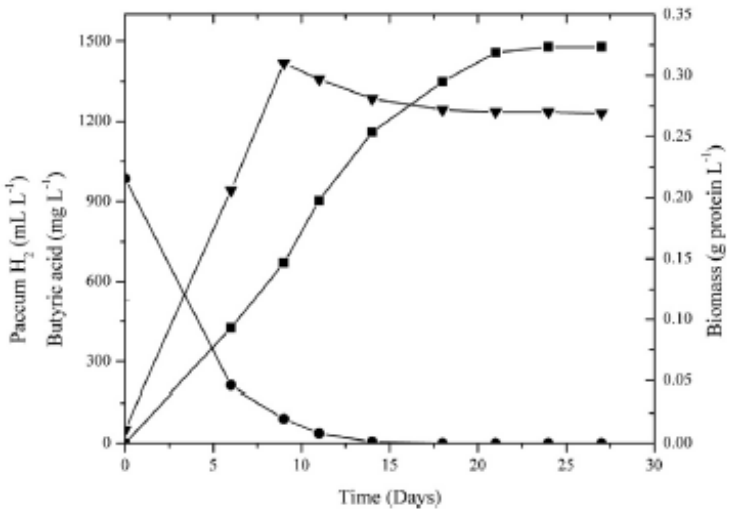

Fig. 2 - IZT culture kinetics under reduced pressure, indoor incubation and $250 \mathrm{mg} \mathrm{NaHCO} \mathrm{L}^{-1}$ supplementation. Biomass ( $\mathbf{v})$, Paccum $\mathrm{H}_{2}(\mathbf{\square})$ and butyric acid removal $(\bullet)$ Error bars are not visible because deviations are very small.
$143.6 \mathrm{~mL} \mathrm{~L}^{-1}$ (SCE of $5 \%$ ) and $135.4 \mathrm{~mL} \mathrm{~L}^{-1}$ (SCE of $4 \%$ ) from acetate and butyr ate, respectively. Lazaro et al. [21] obtained a phototrophic hydrogen-producing bacterial consortium from anaerobic granular sludge from an up-flow anaerobic sludge blanket reactor (UASB) used to treat pig slaughterhouse wastewater. They found an SCE of $15 \%$ for acetate and $14 \%$ for butyrate with hydrogen production rates of 0.4 and $0.9 \mathrm{~mL} \mathrm{H}_{2} \mathrm{~L}^{-1} \mathrm{~h}^{-1}$, respectively. Li et al. [22] removed $29 \%$ acetate and $35 \%$ butyrate with a rate of $5.7 \mathrm{~mL} \mathrm{H}_{2} \mathrm{~L}^{-1} \mathrm{~h}^{-1}$ using an enriched phototrophic sludge from a sediment sample obtained from North River in China.

Effect of the headspace flushing method on cumulative hydrogen production

The second group of bars in Fig. 1 shows that reduced pressure was the best option to stimulate hydrogen production (970 $\left.\mathrm{mL} \mathrm{H}_{2} \mathrm{~L}^{-1}\right)$, compared to flushing with $\mathrm{Ar}\left(635 \mathrm{~mL} \mathrm{H}_{2} \mathrm{~L}^{-1}\right)$ or $\mathrm{CO}_{2}\left(534 \mathrm{~mL} \mathrm{H}_{2} \mathrm{~L}^{-1}\right)$.

Some authors have studied the effect of headspace pressure. Li et al. [4] reported that partial evacuation of the headspace increases the difference between the liquid and gas phase pressures and also reduce the solubility of $\mathrm{H}_{2}$ and $\mathrm{CO}_{2}$ in the medium, enabling the gas release from the medium and

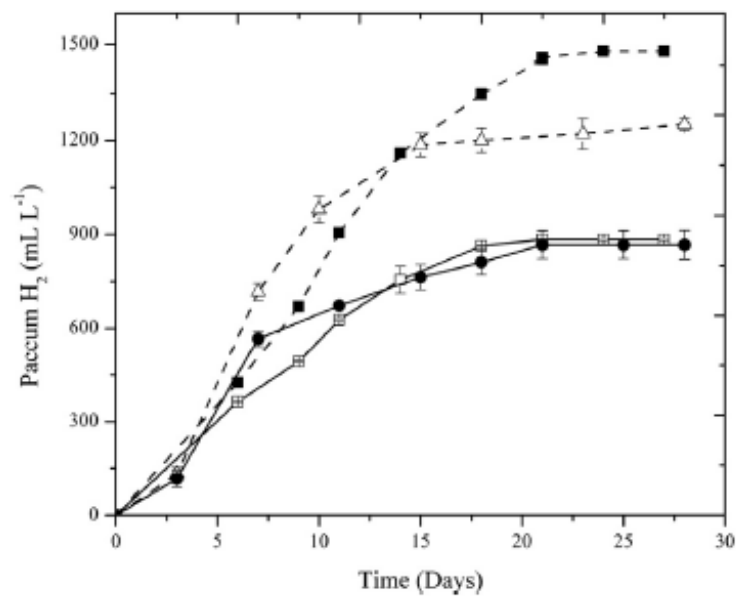

Fig. 3 - Kinetics of cumulative hydrogen production by IZT culture and $R$. capsulatus operated with reduced pressure and $250 \mathrm{mg} \mathrm{NaHCO} \mathrm{L}^{-1}$. The first 5 days all treatments were under indoor conditions. IZT-indoor ( $\square)$, IZT-outdoor $(c)$, R. capsulatus-indoor $(\Delta)$, R. capsulatus-outdoor $(\bullet)$. Error bars are not visible because deviations are very small. 
promoting that reaction equilibrium shifts to the products. These authors observed that total hydrogen produced by $R$. sphaeroides ZX-5 using a mixture of malic and glutamic acid increased from 118 to $131 \mathrm{~mL} \mathrm{H}_{2}$ in $34 \mathrm{~mL}$ of medium and SCE increased $9.5 \%$ with a decrease of the total pressure in the photobioreactor from $1.08 \times 10^{5}$ to $0.94 \times 10^{5} \mathrm{~Pa}$.

In our work, the reduced pressure was $0.11 \times 10^{5} \mathrm{~Pa}$ (atmospheric pressure in México City is $0.78 \times 10^{5} \mathrm{~Pa}-$ negative manometric pressure of $0.66 \times 10^{5} \mathrm{~Pa}$ ), Paccum $\mathrm{H}_{2}$ by IZT culture increased from $1120 \pm 49 \mathrm{~mL} \mathrm{H}_{2} \mathrm{~L}^{-1}$ (with $\mathrm{Ar}$ at atmospheric pressure and $250 \mathrm{mg} \mathrm{L}{ }^{-1}$ of $\mathrm{NaHCO}_{3}$ ) to $1478 \pm 17 \mathrm{~mL} \mathrm{H}_{2} \mathrm{~L}^{-1}$ (with reduced pressure and $250 \mathrm{mg} \mathrm{L}^{-1}$ of $\mathrm{NaHCO}_{3}$ ) and SCE from $36 \%$ to $48 \%$ under indoor conditions (SCE increased 12\%) (see Table 2). Similarly, reduced pressure improved the hydrogen production by R. capsulatus (Table 2).

Pauss et al. [23] found that, despite its low solubility, hydrogen concentration in digesters was 40-70 times higher than the values calculated from measured hydrogen partial pressures and Henry's coefficient. Reduced pressure limits hydrogen dissolution thus avoiding its re-oxidization by the hydrogenase (NiFe-hydrogenase). Alternatively, in a close system using $\mathrm{Ar}$ atmosphere, the gas pressure rises as hydrogen is produced, favoring mass transfer to the liquid medium and uptake by the hydrogenase.

Some other reports have tested reduced pressure in systems using different hydrogenogenic organisms in dark fermentation and biophotolysis. In contrast to our results, Markov et al. [24] found that hydrogen yields by the cyano-

bacterium Anabaena under partial vacuum were comparable to those with Ar atmosphere and Kataoka et al. [25] and Clark et al. [12] found that the headspace pressure below atmospheric levels in dark fermentation did not have a positive effect on gas production. Therefore, this suggests that reduced pressure has variable effects on $\mathrm{H}_{2}$ production depending on the particular $\mathrm{H}_{2}$-producing microorganism.

Based on our observations and others results, it could be postulated that reduced pressure enhances hydrogen production in photo-fermentative process by both maintaining anaerobic conditions and by removing hydrogen as it is produced, keeping low hydrogen partial pressure and thus shifting the reaction equilibrium to $\mathrm{H}_{2}$ formation.

With respect to $\mathrm{CO}_{2}$ flushing, it was observed that this treatment yielded the lowest hydrogen production (Fig. 1 and Table 2), although it was not completely inhibited. Reactors flushed with $\mathrm{CO}_{2}$ also exhibited the lowest final $\mathrm{pH}$ values, in the range $6.1-6.6$, which are not suitable for hydrogen production. In our case, it was observed that at $\mathrm{pH}$ of $6.5, \mathrm{H}_{2}$ production was very low, becoming nil at $\mathrm{pH} 6$ (data not shown). Neutrophilic microorganisms tend to pump hydrogen ions out of the cell to keep a constant level of the proton driving force when facing an acidic environment. This mechanism reduced the intracellular hydrogen ion content and resulted in a low hydrogen production at $\mathrm{pH} 6.0$ [18].

Liu et al. [11] studied the effect of $\mathrm{Ar}, \mathrm{N}_{2}, \mathrm{CO}_{2}$, and air over the hydrogen production of Rhodopseudomonas faecalis RLD-53. They observed that the highest specific growth rate and $\mathrm{H}_{2}$ production was at $5 \%$ of $\mathrm{CO}_{2}$ and the values decreased as the $\mathrm{CO}_{2}$ increased, with total inhibition at $60 \% \mathrm{CO}_{2}$ using acetate as substrate (acetate does not need an acceptor of electrons for its consumption). In our work, $\mathrm{H}_{2}$ production was initially produced even with $100 \%$ of $\mathrm{CO}_{2}$ in the headspace but, as the incubation proceeds, the $\mathrm{pH}$ decrease coupled to a lower $\mathrm{CO}_{2}$ uptake provoke a further reduction in $\mathrm{H}_{2}$ production. It is known that dilution with $\mathrm{Ar}$ is a possible solution as Liu et al. [11] did; however, it hinders $\mathrm{H}_{2}$ purification, so addition of bicarbonate (see section 'Effect of $\mathrm{NaHCO}_{3}$ addition on phototrophic hydrogen production') could be an alternative to provide an electron acceptor.

Effect of $\mathrm{NaHCO}_{3}$ addition on phototrophic hydrogen production Supplementing bicarbonate to the dark fermentation effluent had a significant effect on the hydrogen production for both cultures. This effect can be clearly seen in the third group of bars in Fig. 1, where average Paccum $\mathrm{H}_{2}$ were 739,865 and $577 \mathrm{~mL} \mathrm{H}_{2} \mathrm{~L}^{-1}$ for treatments with 500,250 and $0 \mathrm{mg} \mathrm{L}^{-1}$ of $\mathrm{NaHCO}_{3}$, respectively. Bicarbonate addition enhanced both hydrogen production and butyric acid consumption.

It can be seen from the results in Table 2 that incomplete butyric acid removal and low $\mathrm{H}_{2}$ production were obtained in experiments flushed with argon when no bicarbonate was added (Ar-N treatments), for R. capsulatus and IZT cultures under both indoor and outdoor conditions. Indeed, the indoor hydrogen production was the lowest $\left(320 \mathrm{~mL} \mathrm{~L}^{-1}\right)$ for R. capsulatus and the VFAs removal was only $63 \%$. Bicarbonate and carbonate play a key role as an electron acceptor when butyric acid is used as substrate, its absence limits the uptake of propionic and butyric acid due to unbalances in the oxidative-reductive potential. Muller [27] reported that each mole of

butyrate used during bacterial growth requires the consumption of $0.7 \mathrm{~mol}$ of $\mathrm{CO}_{2}$. Ormerod [14] found a similar value. During chemoautotrophic and photoautotrophic growth conditions, PNSB use the Calvin-Benson-Bassham cycle (CBB) for the reduction of $\mathrm{CO}_{2}$ into biomass. In contrast, during photoheterotrophic growth $\mathrm{CO}_{2}$ is the preferred electron acceptor when organic carbon serves as the major carbon source and as electron donor. $\mathrm{CO}_{2}$ fixation by $\mathrm{CBB}$ during photoheterotrophic growth is required for substrates having lower oxidation state than cell components, therefore it is absolutely necessary the addition of $\mathrm{CO}_{2}$ or some other oxidized electron acceptor for growth on a reduced substrate such as butyrate [26].

$\mathrm{C}_{4} \mathrm{H}_{8} \mathrm{O}_{2}+\mathrm{CO}_{2}+\mathrm{H}_{2} \mathrm{O} \rightarrow 5\left[\mathrm{CH}_{2} \mathrm{O}\right]$

Takabatake et al. [15] observed that carbonate promoted butyric acid uptake and the microbial growth resulted in significant $\mathrm{H}_{2}$ production. They also observed that a mixed culture of photoheterotrophic bacteria did not grow when sodium carbonate was used as the sole carbon source. It indicated that carbonate was not used as a carbon source for microbial growth. On the other hand, PNSB grow more rapidly with organic carbon sources, such as $\mathrm{C} 4$ dicarboxylic acids, than with $\mathrm{CO}_{2}$. Photosynthetic $\mathrm{CO}_{2}$ fixation is not required and may be suppressed when organic compounds are available for direct assimilation [28]. On the other hand, PNSB can re-assimilate the $100 \%$ of the $\mathrm{CO}_{2}$ generated from the oxidation of a highly reduced organic substrate and even additional $\mathrm{CO}_{2}$ or bicarbonate can be required $[14,27,29]$. 
In our work, we observed that bicarbonate addition did not modify biomass production although it had a positive effect on $\mathrm{H}_{2}$ production. The complex substrate DFE stimulated the PNSB growth, but only the use of bicarbonate kept the redox balance of cells longer allowing them produce more hydrogen.

Despite this knowledge, many investigations have not used bicarbonate to enhance hydrogen production. This is one of the first works that have studied the addition of bicarbonate to the production of hydrogen using dark fermentation effluent.

Effect of outdoor/indoor incubation conditions on phototrophic hydrogen production

Fig. 1 shows that the average hydrogen production for all the outdoor experiments was about a half $\left(468 \mathrm{~mL} \mathrm{H}_{2} \mathrm{~L}^{-1}\right)$ of the indoor hydrogen production $\left(958 \mathrm{~mL} \mathrm{H}_{2} \mathrm{~L}^{-1}\right)$.

Fig. 3 shows that under the conditions shown, the average Paccum $\mathrm{H}_{2}$ was about $350 \mathrm{~mL} \mathrm{H}_{2} \mathrm{~L}^{-1}$ in the first 5 days for IZT culture and R. capsulatus, but diminished thereafter when they were incubated outdoors as compared to the indoor treatments. It was observed that both cultures accumulated similar amounts of hydrogen under outdoor conditions ( $883 \pm 4$ and $866 \pm 46 \mathrm{~mL} \mathrm{H}_{2} \mathrm{~L}^{-1}$, respectively).

The critical factors under outdoor conditions were the temperature fluctuations, high light intensity besides the natural dark cycles. Temperature varied between 12 and $30^{\circ} \mathrm{C}$ and the maximum light intensity was $60 \mathrm{kLux}$ under greenhouse shade cloth.

Boran et al. [30] observed that temperature fluctuations between 5 and $35^{\circ} \mathrm{C}$ affected the hydrogen production: when the temperature was below $20^{\circ} \mathrm{C}$, the hydrogen production

was very low and below $15^{\circ} \mathrm{C}$ there was no production. Avcioglu et al. [31] observed a direct relation between $\mathrm{H}_{2}$ production by $R$. capsulatus and solar radiation. Other researchers have demonstrated that little or no hydrogen was produced within dark periods [4], this is due to the strict dependency of the nitrogenase activity on light [32]. Özgür et al. [33] observed that hydrogen production decreased 50\% because the daily temperature fluctuations (between 15 and $40^{\circ} \mathrm{C}$ ) and when the experiments were additionally exposed to light/dark cycles, the hydrogen production decreased $80 \%$. In our work, hydrogen production under outdoor conditions was about half as that shown under indoor conditions despite the environmental fluctuations.

\section{PHB accumulation}

Analysis of variance for PHB accumulation showed in Table 3 indicates that culture type $(p<0.0009)$, headspace flushing method $(p<0.0056)$ and incubation conditions $(p<0.0142)$ have a significant effect on PHB accumulation. In Table 2, PHB production shows that $R$. capsulatus accumulated, on average, more PHB than the IZT culture but in both cases PHB and $\mathrm{H}_{2}$ production were negatively correlated showing that the products compete for the available energy.

The ability to accumulate PHB by PNSB depends on type of substrate, $\mathrm{pH}$, incubation conditions and the PNSB strains and their metabolic pathways, as mentioned previously.

Regarding to the relationship between the type of headspace flushing method and production of PHB, Ar flushing induced a higher PHB production, followed by reduced pressure and $\mathrm{CO}_{2}$ flushing in third place. PHB accumulation has been related to $\mathrm{pH}$ in a direct way, and to the type of headspace in an indirect form. It is known that when the $\mathrm{pH}$ is alkaline or slightly alkaline PHB production is favored. Khatipov et al. [34] reported that a $\mathrm{pH}$ rise from 6.8 to 7.5 induced a reduction in the hydrogen production but the PHB accumulation triples as the $\mathrm{pH}$ rises. In this work, $\mathrm{CO}_{2}$ in the headspace promoted liquid medium acidification through its dissolution as carbonic acid, so the $\mathrm{pH}$ decreased to 6.1-6.6. On the other hand, vacuum application has the opposite effect by removing the $\mathrm{CO}_{2}$ produced during fermentation and fostering neutral $\mathrm{pH}$ 6.9-7.1. In Ar flushing treatments, where final $\mathrm{pH}$ was in the range $7.5-7.8$, resulted with high PHB accumulation. In these treatments, Ar did not influence in the $\mathrm{pH}$ and therefore the $\mathrm{pH}$ increased when the phosphate buffer capacity was depleted.

PHB accumulation by R. capsulatus was significantly lower under indoor conditions (70 $\mathrm{mg}$ PHB $\mathrm{gdw}^{-1}$ on average) than with the higher irradiance found outdoors (190 $\mathrm{mg} \mathrm{PHB} \mathrm{gdw}^{-1}$ ) (see Table 2). PNSB can accumulate more PHB [36] at high outdoor irradiation. However, the IZT culture showed low variation in PHB accumulation (68 and $52 \mathrm{mg} \mathrm{PHB} \mathrm{gdw}^{-1}$ under indoor and outdoor conditions, respectively).

The previous results indicate that IZT culture has low capacity for accumulating PHB intrinsically, therefore, despite the alkaline $\mathrm{pH}$ in treatments purged with $\mathrm{Ar}$ or temperature fluctuations and high irradiation that induce PHB production, IZT culture does not accumulate large amount of PHB. In contrast, R. capsulatus having the ability to accumulate PHB, was significantly affected by the incubation

conditions. We can infer that the IZT culture may have other species, such as R. palustris, that have a weak capacity to cumulate PHB.

Table 2 shows that $R$. capsulatus under $\mathrm{Ar}$ atmosphere with $250 \mathrm{mg} \mathrm{L}^{-1} \mathrm{NaHCO}_{3}$ reached $414 \pm 5 \mathrm{mg} \mathrm{PHB} \mathrm{gdw}^{-1}$ corresponding to $29 \%$ by weight of PHB referred to the protein content, which is considered to be about $40 \%$ of the active biomass. Between 30 and $50 \%$ of production cost of PHB is the cost of raw material [35], this suggests that the use of DFE as substrate and cultivation under outdoor conditions might considerably reduce the production cost of PHB by $R$. capsulatus.

\section{COD removal}

The analysis of variance for the COD removal is shown in Table 3, it exhibits that all factors, culture type, headspace flushing method, incubation conditions (all with $p<0.0001$ ) and bicarbonate concentration $(p=0.0130)$ have a significant effect on COD removal. IZT culture showed a high capacity for COD removal and the highest hydrogen production experiments correspond to the highest COD removal results (see Table 2). Under indoor conditions the experiment with IZT culture at reduced pressure with $250 \mathrm{mg} \mathrm{L}^{-1} \mathrm{NaHCO}_{3}$, the VFAs and other medium components were consumed in the process to reach $89 \%$ of COD removal; under outdoor conditions, the IZT culture reached a COD removal of $80 \%$ (see Table 2). With respect to $R$. capsulatus, the setting reduced pressure$250 \mathrm{mg} \mathrm{L}^{-1} \mathrm{NaHCO}_{3}$ showed a COD removal around $65 \%$ and 


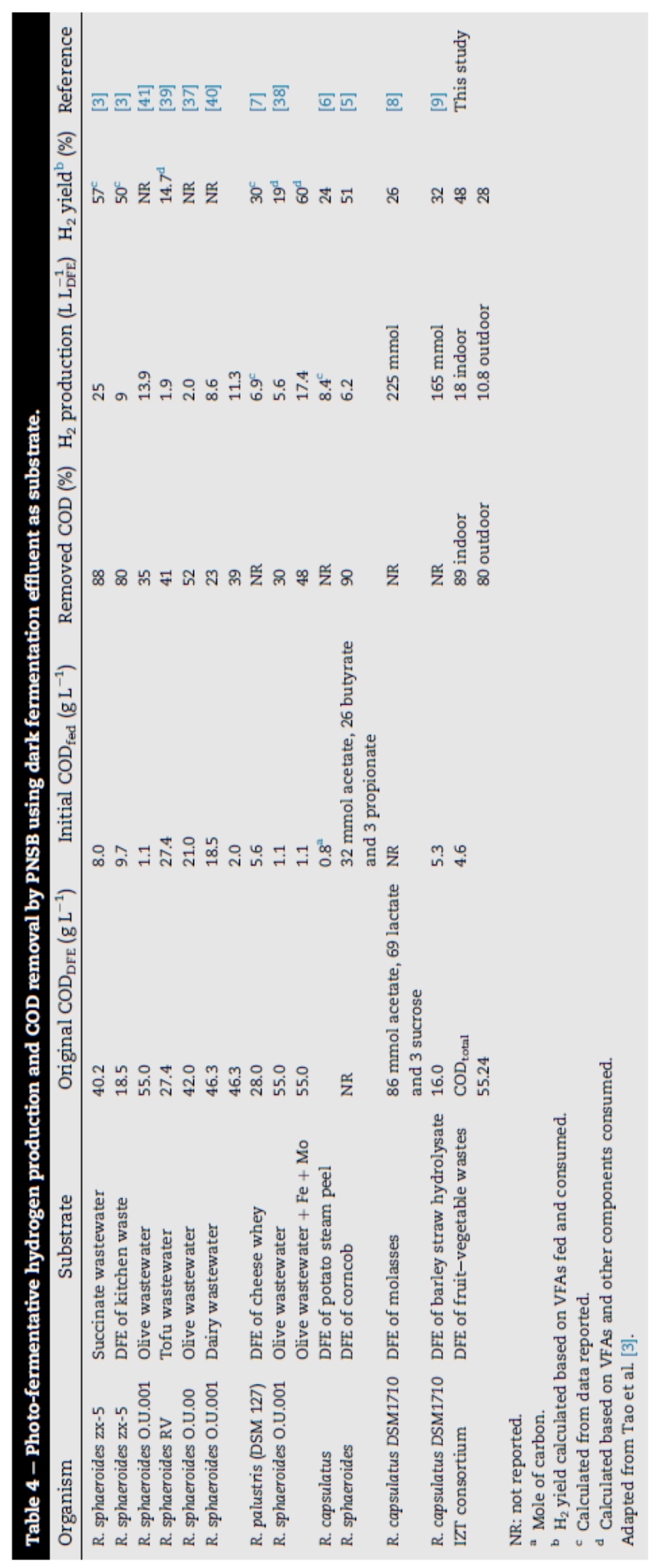


$68 \%$ for treatments at indoors and outdoors, respectively. These results suggest that PNSB, obtained from natural sources or wastewater, could have high COD removal capabilities and hydrogen production, representing an excellent alternative for organic waste treatment.

In experiments with reduced pressure, the highest values of COD removal and Paccum $\mathrm{H}_{2}$ were obtained (see Table 2). This can be related to the neutral pH (between 6.9 and 7.1) which also fosters higher biomass contents $\left(0.25 \mathrm{~g}\right.$ protein $\mathrm{L}^{-1}$ in average) as compared to those obtained with $\mathrm{Ar}$ or $\mathrm{CO}_{2}$ ( 0.16 and $0.18 \mathrm{~g}$ protein $\mathrm{L}^{-1}$, respectively). High biomass content also reflects improved COD removal. In experiments using $\mathrm{CO}_{2}$ for headspace degassing, the $\mathrm{pH}$ was lower (6.1-6.6) affecting biomass growth, $\mathrm{H}_{2}$ production and $\mathrm{COD}$ removal.

Table 4 shows the hydrogen production and COD removal by photo-fermentation reported by different authors that used dark fermentation effluents as substrate under indoor conditions, batch and sterile condition. It can be seen, that COD removal obtained in our work was above that reported by Eroglu et al. [37,38], Zhu et al. [39], Seifert et al. [40] and others who employed pure cultures obtained from microbial collections; and close to those obtained by Tao et al. [3] who employed a PNSB strain isolated from wastewater. Although acetate, butyrate and carbohydrates may be more recalcitrant than succinate, lactate or malate by PNSB for hydrogen pro-

duction, in our work $18 \mathrm{~L} \mathrm{H}_{2}$ were obtained per liter of DFE from fruits and vegetables wastes high in butyric acid and other complex compounds representing $55 \mathrm{~g}$ COD in total. Tao et al. [3] obtained $25 \mathrm{~L} \mathrm{H}_{2} \mathrm{~L}^{-1}$ from a succinate polluted wastewater, been the succinate acid an easily metabolized substrate by PNSB, however, when they used a DFE of kitchen wastes with $7.7 \mathrm{~g} \mathrm{~L}^{-1}$ and $3.4 \mathrm{~g} \mathrm{~L}^{-1}$ of acetic acid and butyric acid, respectively, the hydrogen production diminished considerably to $9 \mathrm{~L} \mathrm{H}_{2} \mathrm{~L}^{-1}$ (see Table 4). However, in our work the initial COD was lower than the used by Tao et al. [3]. When initial COD of 9 and $13.6 \mathrm{~g} \mathrm{~L}^{-1}$ were tested there was no hydrogen production because biomass significantly increased (data not shown) for the high nitrogen content in the DFE used as substrate (see Table 1), interfering with the light penetration in the culture.

The initial COD or dilution factor depends on the type and composition of DFE or wastewater, for example, when Eroglu et al. [41] used an initial COD of $1.1 \mathrm{~g} \mathrm{~L}^{-1}$ (implying dilute 50 times the olive wastewater) they obtained $13.9 \mathrm{~L} \mathrm{H}_{2} \mathrm{~L}^{-1}$, but hydrogen could not be produced when they used an initial COD of $3.3 \mathrm{~g} \mathrm{~L}^{-1}$. The reasons might be the presence of high amounts of inhibitory substances and their relatively dark color of olive wastewater. One way to minimize the use of water for dilution could be the reuse the spent effluent of the photo-fermentation stage in a new cycle of hydrogen production.

In Table 4 , it can be seen that the $\mathrm{H}_{2}$ yields (\%) based on the consumption of VFAs obtained in this study are higher than those reported by Afsar et al. [6], Eroglu et al. [38] and, Azbar and Dokgöz [7] and similar to those obtained by Tao et al. [3] and Yang et al. [5]. Additionally, it was possible to carry out the process under non-sterile conditions, representing an operational and economic advantage when scaling the process.

\section{Conclusions}

This study demonstrated the feasibility of the photofermentative $\mathrm{H}_{2}$ production with reduced pressure, nonsterile and under indoor/outdoor conditions, by PNSBenriched culture using dark fermentation effluent as substrate. Hydrogen production by the photoheterotrophic IZT culture was comparable to specialized hydrogen producer $R$. capsulatus. The results strongly suggest that flushing with $\mathrm{Ar}$ could be replaced with reduced pressure, which can be less expensive and practical for hydrogen recuperation. Furthermore in this work, $\mathrm{H}_{2}$ production was improved with the addition of bicarbonate to DFE. IZT culture achieved better removals of COD compared to R. capsulatus, but R. capsulatus accumulates more PHB, therefore if treatment of waste (DFE) is required in addition to hydrogen production specialized enriched cultures, such as IZT, should be used, and R. capsulatus if the production of an added value compound is needed.

Hydrogen production under outdoor conditions was not negligible and would provide energy savings by using natural illumination as energy source helping to integrate photofermentative hydrogen production to waste treatment systems.

\section{Acknowledgments}

Authors thank to Dra. Inés Garcia for kindly providing the dark fermentation effluent. They also acknowledge the scholarship provided by the National Council of Science and Technology (CONACYT)

\section{RE F E RE N C ES}

[1] Kim DH, Kim MS. Development of a novel three-stage fermentation system converting food waste to hydrogen and methane. Bioresour Technol 2013;127:267-74.

[2] Cai J, Wang G, Pan G. Hydrogen production from butyrate by a marine mixed phototrophic bacterial consort. Int J Hydrog Energy 2012;37:4057-67.

[3] Tao Y, He Y, Wu Y, Liu F, Li X, Zong W, et al. Characteristics of a new photosynthetic bacterial strain for hydrogen production and its application in wastewater treatment. Int $J$ Hydrog Energy 2008;33:963-73.

[4] Li X, Wang Y, Zhang S, Chu J, Zhang M, Huang M, et al. Effects of light/dark cycle, mixing pattern and partial pressure of $\mathrm{H}_{2}$ on biohydrogen production by Rhodobacter sphaeroides ZX-5. Bioresour Technol 2011;102:1142-8.

[5] Yang H, Gou L, Liu F. Enhanced bio-hydrogen production from corncob by a two-step process: dark- and photofermentation. Bioresour Technol 2010;101:2049-52.

[6] Afsar N, Özgür E, Gürgan M, Akköse S, Yücel M, Gündüz U, et al. Hydrogen productivity of photosynthetic bacteria on dark fermenter effluent of potato steam peels hydrolysate. Int J Hydrog Energy 2011;36:432-8.

[7] Azbar N, Dokgöz FTC. The effect of dilution and L-malic acid addition on bio-hydrogen production with Rhodopseudomonas palustris from effluent of an acidogenic anaerobic reactor. Int J Hydrog Energy 2010;35:5028-33. 
[8] Özgür E, Afsar N, de Vrije T, Yücel M, Gündüz U, Claassen PAM, et al. Potential use of thermophilic dark fermentation effluents in photofermentative hydrogen production by Rhodobacter capsulatus. J Clean Prod 2010;18:S23-8.

[9] Özgür E, Peksel B. Biohydrogen production from barley straw hydrolysate through sequential dark and photofermentation. J Clean Prod 2013;52:14-20.

[10] Koku H, Eroğlu I, Gundüz U, Yücel M, Türker L. Aspects of the metabolism of hydrogen production by Rhodobacter sphaeroides. Int J Hydrog Energy 2002;27:131-229.

[11] Liu BF, Ren NQ, Ding J, Xie GJ, Cao GL. Enhanced photo- $\mathrm{H}_{2}$ production of $\mathrm{R}$. faecalis RLD- 53 by separation of $\mathrm{CO}_{2}$ from reaction system. Bioresour Technol 2009;100:1501-4.

[12] Clark IC, Zhang RH, Upadhyaya SK. The effect of low pressure and mixing on biological hydrogen production via anaerobic fermentation. Int J Hydrog Energy 2012;37:11504-13.

[13] Kim DH, Shin HS, Kim SH. Enhanced $\mathrm{H}_{2}$ fermentation of organic waste by $\mathrm{CO}_{2}$ sparging. Int J Hydrog Energy 2012;37:15563-8.

[14] Ormerod JG. The use of radioactive carbon dioxide in the measurement of carbon dioxide fixation in Rhodospirillum rubrum. Biochem J 1956;64:373-80.

[15] Takabatake H, Suzuki K, Ko IB, Noike T. Characteristics of anaerobic ammonia removal by a mixed culture of hydrogen producing photosynthetic bacteria. Bioresour Technol 2004;95:151-8.

[16] Kars G, Gundüz U. Towards a super $\mathrm{H}_{2}$ producer. improvements in photofermentative biohydrogen production by genetic manipulations. Int J Hydrog Energy 2010;35:6646-56.

[17] Kranz RG, Gabbert KK, Locke TA, Madigan MT. Polyhydroxyalkanoate production in Rhodobacter capsulatus: genes, mutants, expression, and physiology. Appl Environ Microbiol 1997;63:3003-9.

[18] Wu SC, Liou SZ, Lee CM. Correlation between bio-hydrogen production and polyhydroxybutyrate (PHB) synthesis by Rhodopseudomonas palustris WP3-5. Bioresour Technol 2012:113:44-50.

[19] Zúnigiga C, Morales M, Le Borgne S, Revah S. Production of poly-hydroxybutyrate (PHB) by Methylobacterium organophilum isolated from a methanotrophic consortium in a two-phase partition bioreactor. J Hazard Mater 2011;190:876-82.

[20] Aparecida Loss R, Fontes ML, Reginatto V, Vasconcellos Antonio R. Biohydrogen production by a mixed photoheterotrophic culture obtained from a Winogradsky column prepared from the sediment of southern Brazilian lagoon. Renew Energy 2013;50:648-54.

[21] Lazaro CZ, Vich DV, Hirasawa JS, Varesche MBA. Hydrogen production and consumption of organic acids by a phototrophic microbial consortium. Int J Hydrog Energy 2012;37:11691-700.

[22] Li RY, Zhang T, Fang HHP. Characteristics of a phototrophic sludge producing hydrogen from acetate and butyrate. Int J Hydrog Energy 2008; 33:2147-55.

[23] Pauss A, Samson R, Guiot S, Beauchemin C. Continuous measurement of dissolved $\mathrm{H}_{2}$ in an anaerobic reactor using a new hydrogen/air fuel cell detector. Biotechnol Bioeng 1990;35(5):492-501.
[24] Markov SA, Lichtl R, Rao KK, Hall DO. A hollow fibre photobioreactor for continuous production of hydrogen by immobilized cyanobacteria under partial vacuum. Int J Hydrog Energy 1993;18:901-6.

[25] Kataoka N, Miya A, Kiriyama K. Studies on hydrogen production by continuous culture system of hydrogenproducing anaerobic bacteria. Water Sci Technol 1997;36:41-7.

[26] Laguna R, Joshi GS, Dangel AW, Luther AK, Tabita FR. Integrative control of carbon, nitrogen, hydrogen, and sulfur metabolism: the central role of the Calvin-Benson-Bassham cycle. Adv Exp Med Biol 2010;675:265-71.

[27] Muller FM. On the metabolism of the purple sulphur bacteria in organic media. Arch Mikrobiol 1933;4:131-66.

[28] Ormerod JG, Gest H. Hydrogen photosynthesis and alternative metabolic pathways in photosynthetic bacteria. Bacteriol Rev 1962;26:51-66.

[29] Kontur WS, Noguera DR, Donohue TJ. Maximizing reductant flow into microbial $\mathrm{H}_{2}$ production. Curr Opin Biotechnol 2012;23(3):382-9.

[30] Boran E, Ozgür E, van der Burg J, Yücel M, Gündüz U, Eroglu I. Biological hydrogen production by Rhodobacter capsulatus in solar tubular photobioreactor. J Clean Prod 2010;18:S29-35.

[31] Avcioglu SG, Özgür E, Eroglu I, Yücel M, Günduz U. Biohydrogen production in an outdoor panel photobioreactor on dark fermentation effluent of molasses. Int J Hydrog Energy 2011;36:11360-8.

[32] Meyer J, Kelley BC, Vignais PM. Effect of light on nitrogenase function and synthesis in Rhodopseudomonas capsulata. J Bacteriol 1978;136(1):201-8.

[33] Ōzgür E, Uyar B, Ozturk Y, Yücel M, Gündüz U, Eroglu I. Biohydrogen production by Rhodobacter capsulatus on acetate at fluctuating temperatures. Resour Conserv Recycl 2010;54:310-4.

[34] Khatipov E, Miyake M, Miyake J, Asada Y. Accumulation of poly-beta-hydroxybutyrate by Rhodobacter sphaeroides on various carbon and nitrogen substrates. FEMS Microbiol Lett

1998;162:39-45.

[35] Ienczak JL, Schmidell W, Aragao GMF. High-cell-density culture strategies for polyhydroxyalkanoate production: a review. J Ind Microbiol Biotechnol 2013;40:275-86.

[36] Carlozzi P, Sacchi A. Biomass production and studies on Rhodopseudomonas palustris grown in an outdoor, temperature controlled, underwater tubular photobioreactor. J Biotechnol 2001;88:239-49.

[37] Eroglu E, Eroglu I, Gündüz U, Turker L, Yưcel M. Biological hydrogen production from olive mill wastewater with twostage processes. Int J Hydrog Energy 2006;31:1527-35.

[38] Eroglu E, Gündüz U, Yücel M, Eroglu I. Effect of iron and molybdenum addition on photofermentative hydrogen production from olive mill wastewater. Int J Hydrog Energy 2011;36:5895-903.

[39] Zhu H, Suzuky T, Tsygankov A, Asada Y, Miyake J. Hydrogen production from tofu wastewater by Rhodobacter sphaeroides immobilized in agar gels. Int J Hydrog Energy 1999;24:305-10.

[40] Seifert K, Waligorska M, Laniecki M. Hydrogen generation in photobiological process from dairy wastewater. Int J Hydrog Energy 2010;35:9624-9.

[41] Eroglu E, Gündüz U, Yücel M, Türker L, Eroglu I. Photobiological hydrogen production by using olive mil wastewater as a sole substrate source. Int J Hydrog Energy 2004;29:1527-35. 


\section{APÉNDICE 3}

From: Evise <EviseSupport@elsevier.com>

To: mmorales@correo.cua.uam.mx

Sent: Mon, 19 Oct 2015 15:59:12 +0000

Subject: Submission HE_2015_1368 received by International Journal of Hydrogen Energy

Dear Dr. Morales,

Thank you for submitting your manuscript for consideration for publication in International Journal of Hydrogen Energy. Your submission was received in good order.

To track the status of your manuscript, please log into EVISE $®$ http://www.evise.com/evise/faces/pages/navigation/NavController.jspx? JRNL_ACR=HE and go to 'My Submissions'.

Thank you for submitting your work to this journal.

Kind regards,

International Journal of Hydrogen Energy 


\section{APÉNDICE 4}
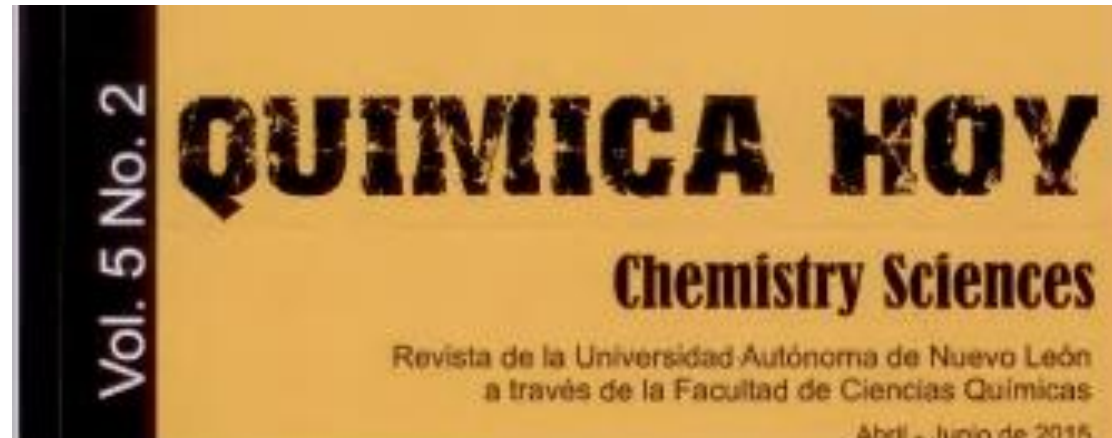

Revista de la Universidad Autónoma de Nuevo León a través de la Facultad de Ciencias Quimicas

Abril-Junio de 2015

ISSN $2007-1183$

ำ
in
ì
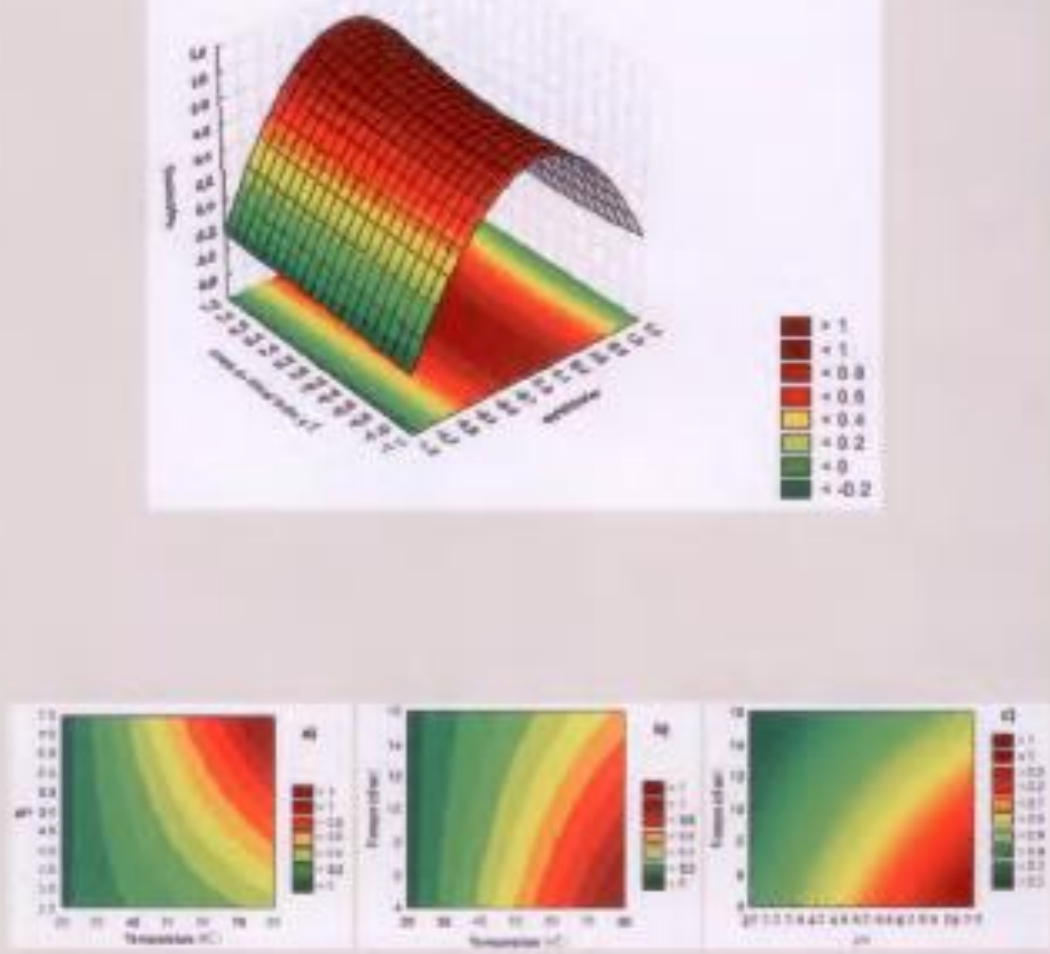


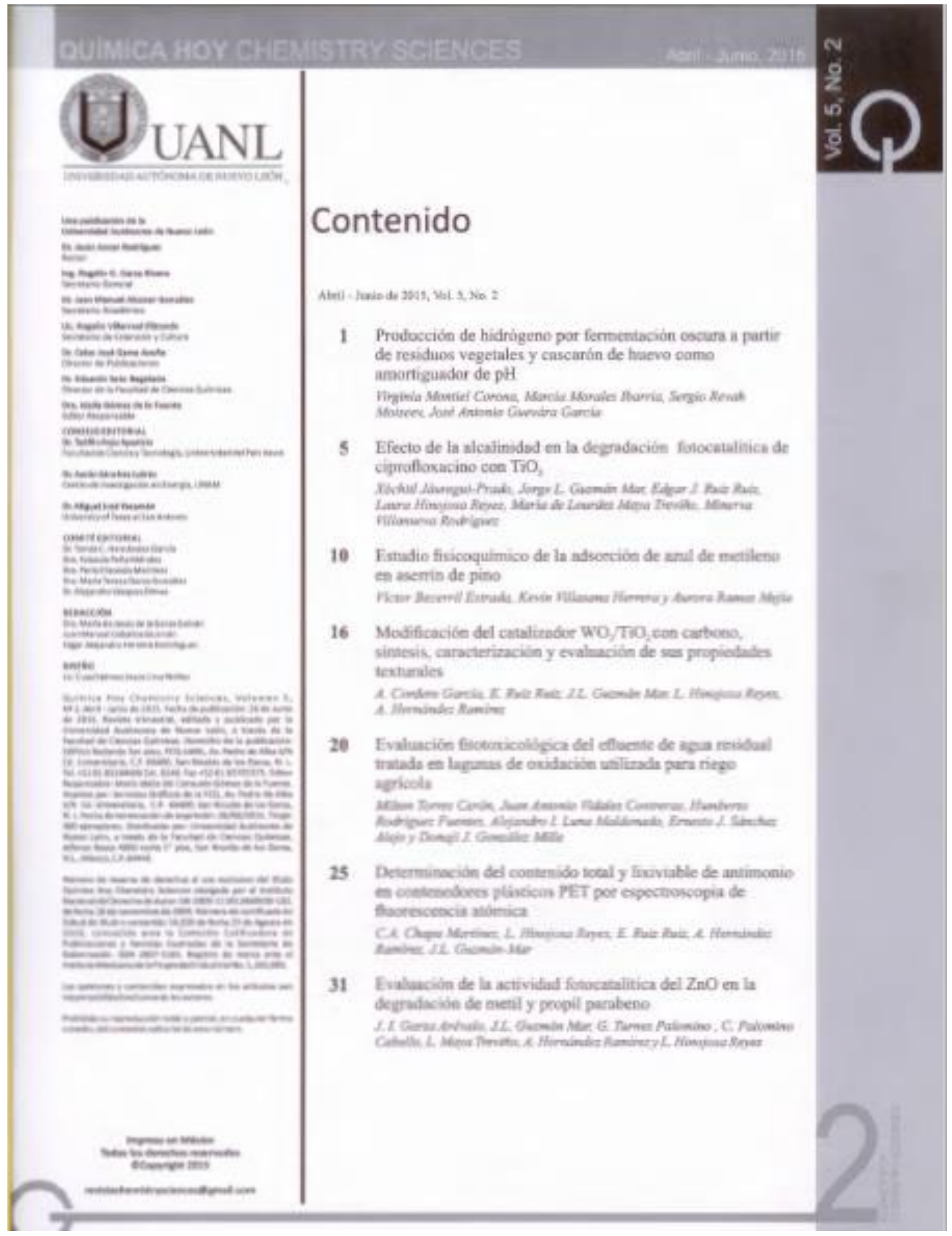




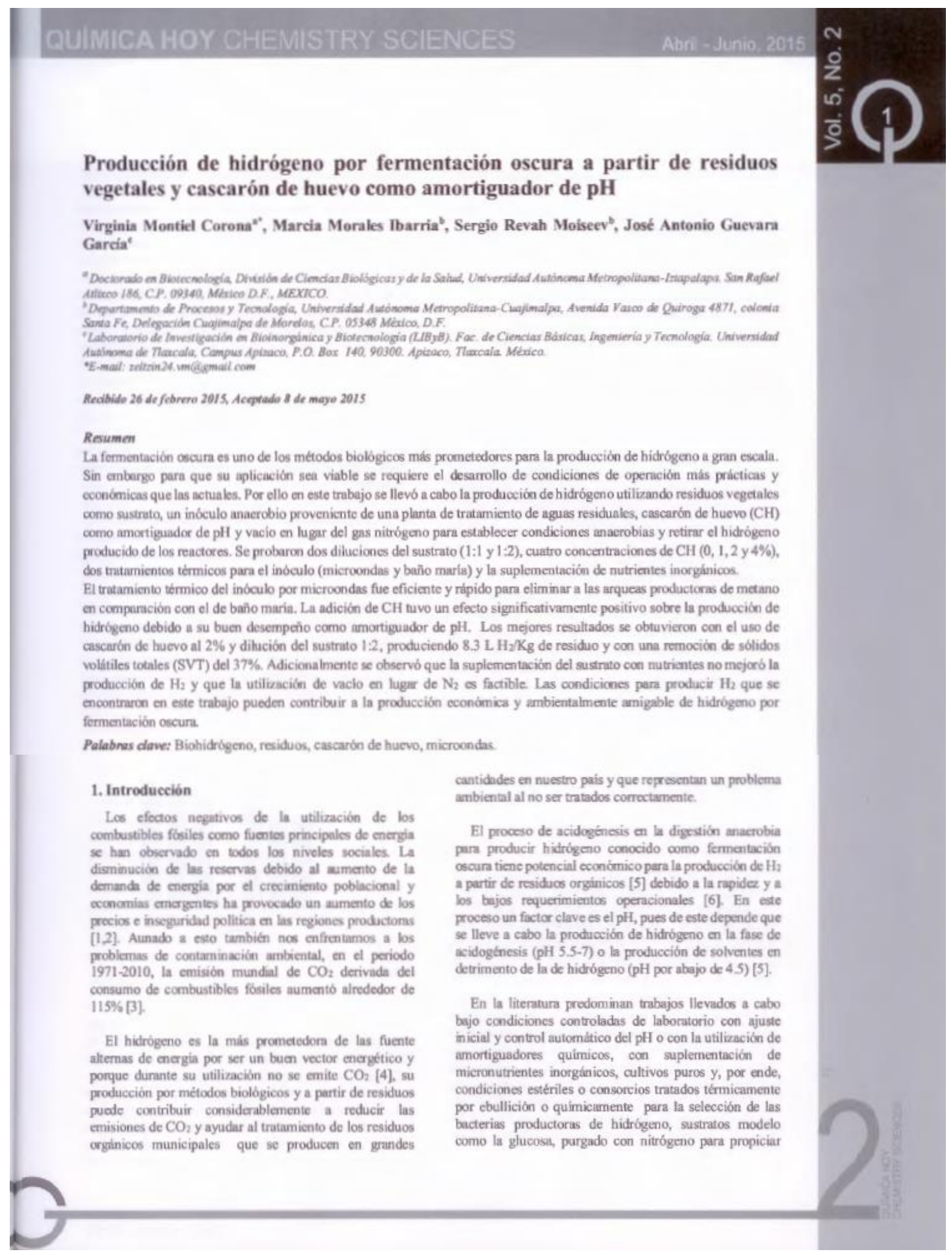




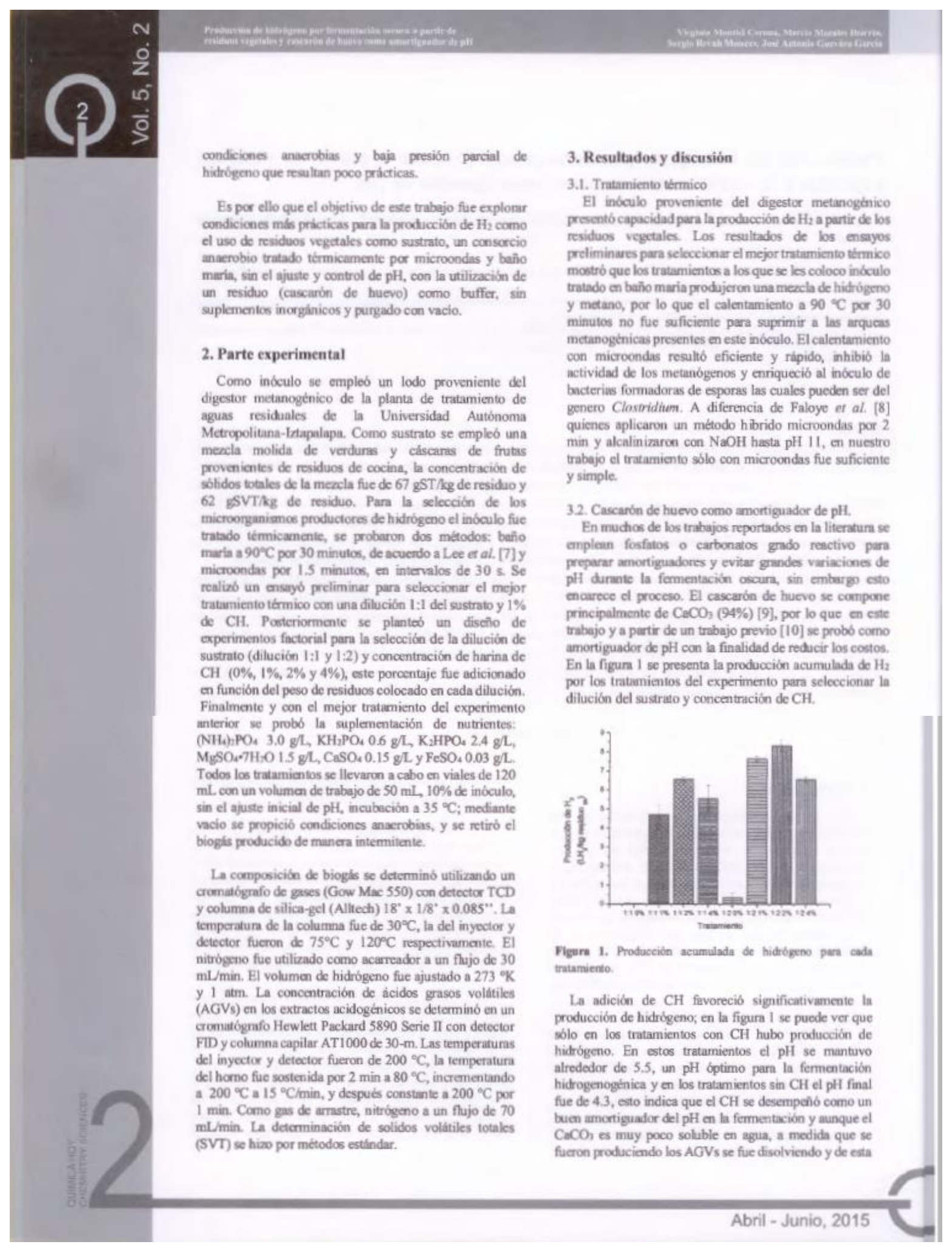




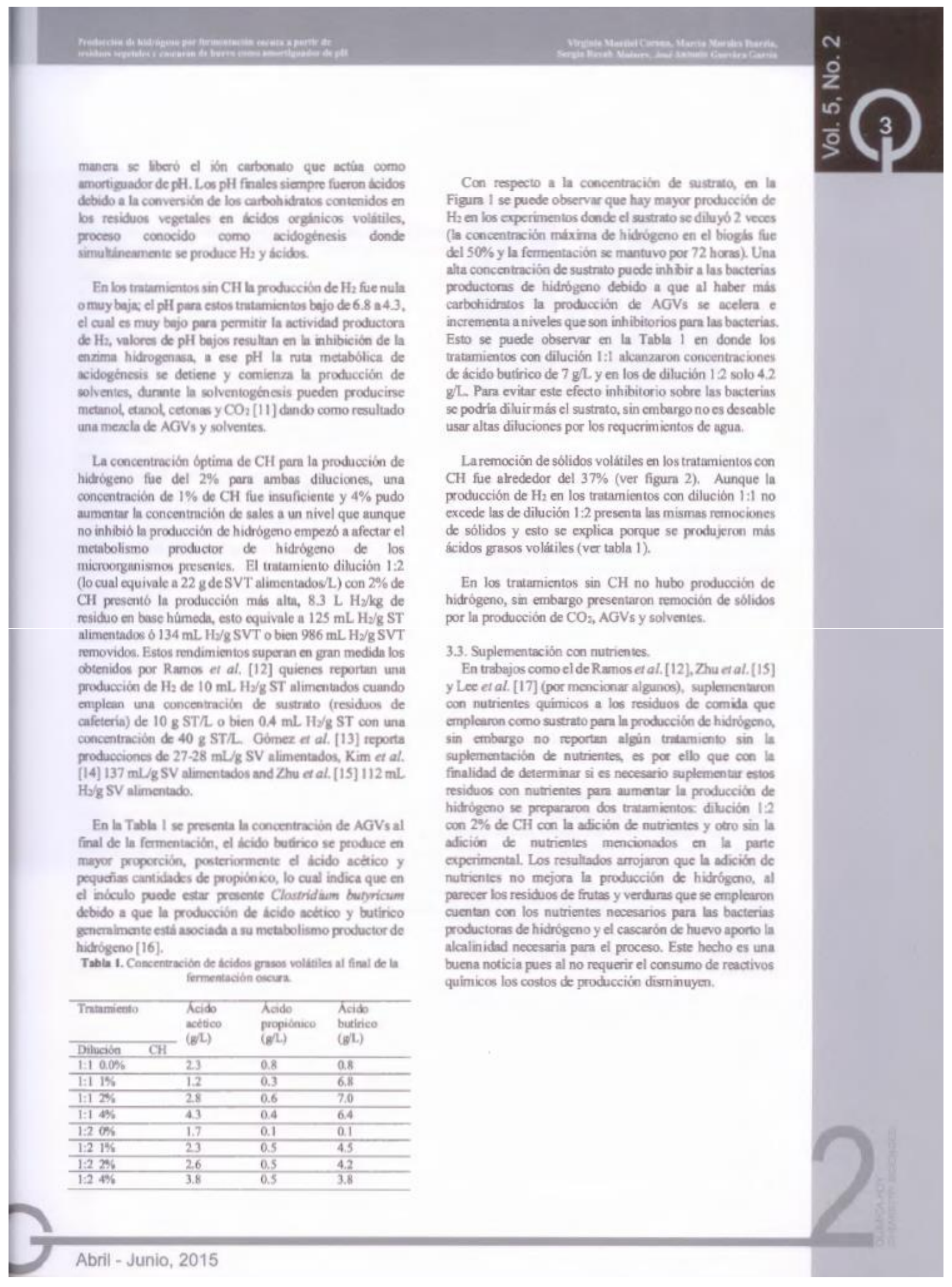




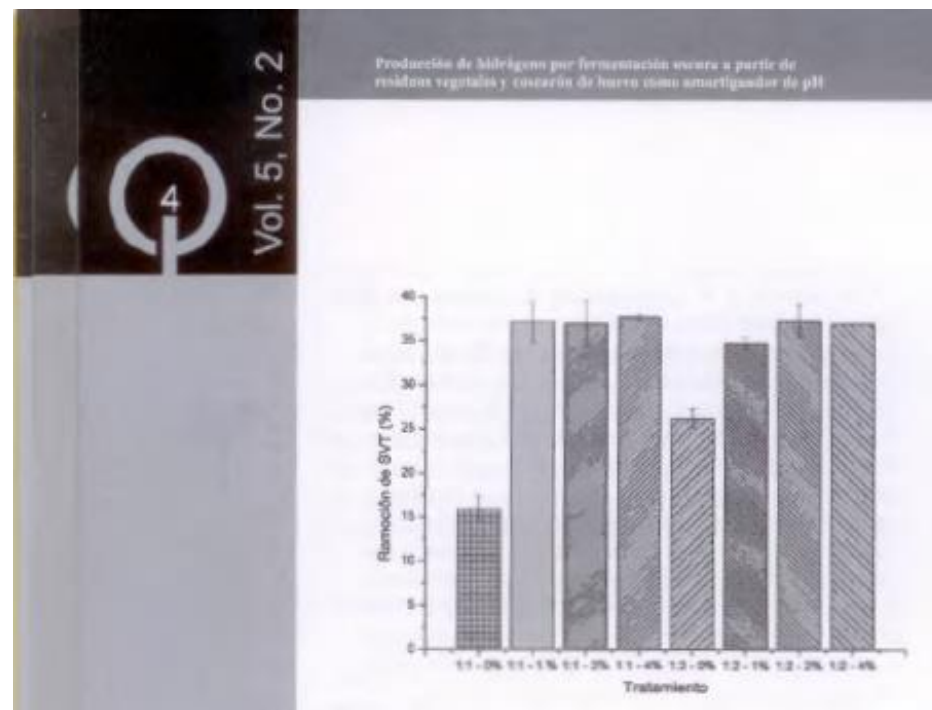

Figurn 2. Remoción de solidon volasiles totales on cada tratamierto.

\subsection{Purgado con vacio}

En todos los tratamientos se uso vacio para propiciar condiciones anuerobias y retirar el hidrógeno producido en lugar de purgar con nitrógeno como comúnmante se hace, el utilizar nitrogeno encarece el proceso primero por el gasto que implica adquirirlo y scgundo porque dificulta la purificación del hidrógeno.

Otra ventaja de emplear vacio y mantener la presión del reactor por debajo de la presión atmosférica es que se puede tenc un efecto positivo en los rendimientos de producción de hidrógeno, Becker et al. [17] observaron un aumento en los rendimientos del $7 \%$ al mantener la presićn del reactor por debajo de la presión atmosférica.

\section{Conclusiones}

En este trabajo se encontraron condiciones mis pricticas y económicas para la producción de $\mathrm{H}_{2}$ por fermentación oscura Se encontró que se pueden obtener buenos rendimientos de $\mathrm{H}_{2}$ utilizando residuos vegetales como sustrato sin la utilización de sustancias quimicas para regular el $\mathrm{pH}$ y $\sin$ la adición de nutrientes. B cascarón de huevo funcionó bien como amortiguador de $\mathrm{pH}$. Además la utilización de microondas para la selecoión de bacterias productoras de $\mathrm{H}_{2}$ fue eficaz y la utilización de vacio cr lugar de nitrógeno facilita la purificación del Hz producido.

\section{Referendias}

1. Kothan, R.; Tyagi, V.V; Pathak, A. Renew, Sust. Enery. Rev. 2010,14, 3164-3170.

2. Bletschwitz, R; Bader, N. Enarg. Policy, 2010,38, $5297-5300$.

3. SEMARNAT. http:/www.semarnat.gob.mx (accesado el 7 de julio de 2014).

4. Kapdan, I.K.; Kargi, F. Ensyme Microb Technol. 2006, 38, $569-582$

5. Gadhamshetty, V; Johnson, D.C; Nimalakhandan, N.; Smith G.B.; Deng S. Int. J. Hydnogen Energy. 2009.34, 1233-1243.

6. Chang P.I. Hisu, C.W. Int J. Hydrogen Energy. 2012 $37,15746-15752$.

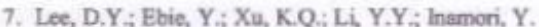
Bionesource Technol. 2010, 101, S42-S47.

8. Faloye, F.D; Gucguim Kana, E. B; Schmidt, S. Int. J. Hydrogen Energy. 2014, 1-10.

9. Stadelman, W.J. Encolopodia of food science and technology. John Wiley \& Scens, New York: 2000: pp. 593-599.

10. Monticl Corona, V.; Sanchez Camarillo, A.R.; Guevara Garcia J.A. Ciencia, Tecnología e Innovación pana el Desarmollo de Mexios, PCTI 2010, 66. Sitio de internet: hitpi//petimx.

11. De Giounis, G.i. Muntoni, A.;. Polettini, A.; Pomi, R. Waste Manage. 2013, 33, 1345-1361.

12. Ramos, C; Buitrón, G.; Moreno-Andrade, I; Chamy, R. Int I Hufrogen Energy 2012, 37, 13288 -13295.

13.Gúmez, X: Cuctos, M.J. Pricto, JI:; Morain, A. Remew, Enerxy, 2009, 34, 970-975.

14.Kim, D.H.; Wu, J; Joong K.W; Kim, M.S.; Shin, H.S. Int J. Hydrogen Energy, 2011, 36, 10666-10673.

15. Zhu, H.; Pavker, W; Basnar R.; Pronacki, A.; Falletta, P.; Belanda, M.; Seto, P. eter Setoa. Int. J. Hydrogen Energy, 2008, 33, 3651-3659.

16. Beckers, L.; Hiligsman, S.; Masset, J.; Hamilton, C.; Thonart, P. Energy Pnocadia. 2012, 29, $34-41$

17.Lee, Z.K.; Li, S.L.; Lin, J.S.; Wang, Y.H.; Kuo, P.H.; Chang S.S. Int. J. Hydrogen Energy. 2008, 33, 52345241 . 